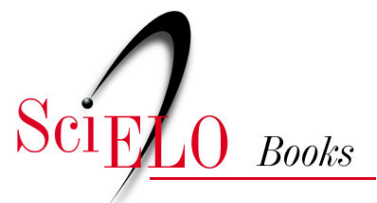

\title{
Os médicos no Brasil
}

um retrato da realidade

\author{
Maria Helena Machado \\ (coord.)
}

MACHADO, MH., coord. Os médicos no Brasil: um retrato da realidade. [online]. Rio de Janeiro: Editora FIOCRUZ, 1997. 244 p. ISBN: 85-85471-05-0. Available from SciELO Books <http://books.scielo.org>.

\section{(c) (1) @(2)}

All the contents of this work, except where otherwise noted, is licensed under a Creative Commons Attribution-Non Commercial-ShareAlike 3.0 Unported.

Todo o conteúdo deste trabalho, exceto quando houver ressalva, é publicado sob a licença Creative Commons Atribuição Uso Não Comercial - Partilha nos Mesmos Termos 3.0 Não adaptada.

Todo el contenido de esta obra, excepto donde se indique lo contrario, está bajo licencia de la licencia Creative Commons Reconocimento-NoComercial-CompartirIgual 3.0 Unported. 


\section{Os Miédicos no Brasil um retrrato da realidade}

Maria Helena Machado

(Coordenadora) 


\section{Os Médicos no Brasil um retrato da realidade}




\section{FUNDAÇÃO OSWALDO CRUZ}

Presidente

Eloi de Souza Garcia

Vice-Presidente de Ambiente, Comunicação e Informação

Maria Cecília de Souza Minayo

\section{EDITORA FIOCRUZ}

Coordenadora

Maria Cecilia de Souza Minayo

Conselho Editorial

Carlos E. A. Coimbra Jr.

Carolina M. Bori

Charles Pessanha

Hooman Momen

Jaime L. Benchimol

José da Rocha Carvalheiro

Luiz Fernando Ferreira

Miriam Struchiner

Paulo Amarante

Paulo Gadelha

Paulo Marchiori Buss

Vanize Macêdo

Zigman Brener

Coordenador Executivo

João Carlos Canossa P. Mendes 


\section{Os Médicos no Brasil um retrato da realidade}

Maria Helena Machado

(Coordenadora)

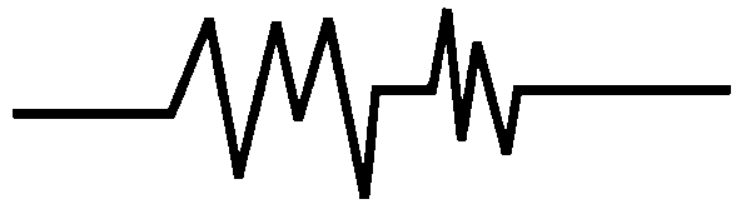

$1^{\mathbf{a}}$ Reimpressão

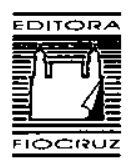


Copyright @1997 dos autores

Todos os direitos desta ediçāo reservados à

FUNDAÇĀO OSWALDO CRUZ/ EDITORA

ISBN: $85-85471-05-0$

$1^{\text {a }}$ Reimpressão: 1999

Projeto Gráfico e Editoraçăo Eletrônica:

Heloisa Diniz

Capa:

Mauro Campello

Copidesque:

M. Cecília G. B. Moreira

Revisão:

Fani Knoploch

Marcionilio Cavalcanti de Paiva

Supervisão Editorial:

Walter Duarte

Catalogação-na-fonte

Centro de Informação Científica e Tecnológica

Biblioteca Lincoln de Freitas Filho

M149m Machado, Maria Helena (coord.)

Os médicos no Brasil: um retrato da realidade. / coordenado por Maria Helena Machado. - Rio de Janeiro: Fiocruz, 1997.

244p., tab. graf.

1. Médicos-Brasil. 2. Educação médica-Brasil. 3. Médicos-provisão e distribuição-Brasil.

CDD. - 20. ed. - 331.10981

1999

EDITORA FIOCRUZ

Rua Leopoldo Bulhões, 1480, Térreo - Manguinhos

21041-210 - Rio de Janeiro - RJ

Tel.: (21) 598-2701 e 598-2702

Telefax.: (21) 598-2509 


\section{AUTORES}

Maria Helena Machado (Coordenadora)

Socióloga, doutora em Sociologia

Sérgio Rego

Médico, mestre em Saúde Coletiva, doutorando em Saúde Coletiva

Eliane dos Santos de Oliveira

Nutricionista, mestre em Saúde Pública

José de Azevedo Lozana

Estatístico, mestre em Estatística

Sandra Rosa Pereira

Socióloga, especialista em Desenvolvimento de Recursos Humanos em Saúde

Luiz Felipe Pinto

Estatístico, mestrando em Saúde Pública

Monica Campos

Estatística, mestranda em Saúde Pública

Fernando Sertã

Economista, mestrando em Economia

Marcelo Levy dos Santos Braga

Historiador, cursando Especialização em Desenvolvimento de Recursos Humanos em Saúde

Eduardo Rocha Barcellos

Graduando em Ciências Econômicas

" Todos os autores fizeram parte da equipe técnica da pesquisa "Perfil dos Médicos no Brasil", sediada no Núcleo de Estudos em Recursos Humanos em Saúde, do Departamento de Administração e Planejamento em Saúde da Escola Nacional de Saúde Pública/Fiocruz. 
Dedicamos este livro a todos os médicos brasileiros.

Nossa homenagem especial à saudosa professora Maria Cecília Donnangelo. 


\section{SUMÁRIO}

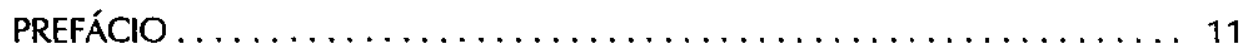

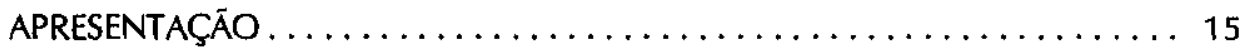

1. CARACTERÍSTICAS SOCIOLÓGICAS DA PROFISSĀO MÉDICA . . . . . 21

2. A FORMAÇĀO PROFISSIONAL $\ldots \ldots \ldots \ldots \ldots \ldots \ldots \ldots \ldots \ldots \ldots \ldots \ldots \ldots \ldots \ldots \ldots$

3. A ESTRUTURA DO MERCADO DE TRABALHO MÉDICO $\ldots \ldots \ldots \ldots \ldots 81$

4. DINÂMICA DO MERCADO DE TRABALHO ............... 99

5. AS MÉDICAS NO BRASIL $\ldots \ldots \ldots \ldots \ldots \ldots \ldots \ldots \ldots \ldots \ldots . \ldots \ldots 7$

6. AS CONDIÇÕES DE TRABALHO MÉDICO .............. 163

7. OS MÉDICOS E A PARTICIPAÇÃO NA VIDA POLÍTICO-SINDICAL . . . . . 187

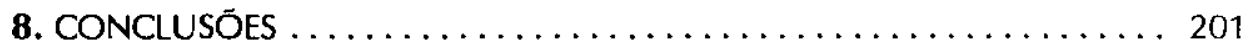

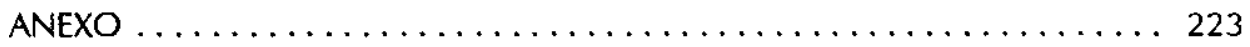

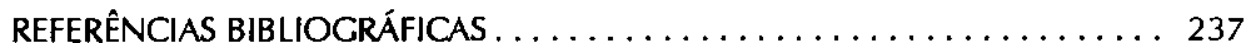




\section{PREFÁCIO}

Faz-se necessário, primeiramente, frisar a importância desta obra, não apenas para a comunidade médica em particular, mas para a sociedade como um todo. Mais que um estudo enfocando a área de recursos humanos, a pesquisa "Perfil dos Médicos no Brasil" representa a concretização e viabilização de um projeto por longos anos almejado pelas entidades médicas.

Para melhor compreensão, é essencial nos reportarmos à década de 80 , a qual, no Brasil, foi notadamente caracterizada por profundas e marcantes modificações e/ou reestruturações no campo da saúde, com inegáveis conquistas para a medicina - como a incorporação de grande parte da tecnologia atualmente utilizada -, propiciando diagnósticos apurados, tratamentos precoces e cada vez menos agressivos ao organismo humano.

Na área da política de saúde, o País viveu momentos de intensa participação da sociedade, por ocasião da realização das conferências nacionais de saúde, culminando com a elaboração, em outubro de 1988, da nova Constituição brasileira, que inseriu a saúde como um dos títulos da ordem social. Em seu artigo 196, frisa, especificamente, que "a saúde é direito de todos e dever do Estado, garantido mediante políticas sociais e econômicas que visem à redução do risco de doenças e de outros agravos e ao acesso universal e igualitário às ações e serviços para sua promoçāo, proteção e recuperação".

Por sua vez, o artigo 198 explicita que as ações e serviços públicos de saúde integrariam uma rede regionalizada e hierarquizada, constituindo um sistema único de saúde, organizado sob as diretrizes da descentralização, atendimento integral e participação da comunidade, estruturado de modo a proporcionar o acesso universal e gratuito dos cidadãos quando da necessidade de assistência à saúde.

$O$ avanço desse sistema significava o estabelecimento de uma nova racionalidade na organização e prestação dos senviços, a harmonização entre o público e o priva- 
do, bem como a possibilidade da criação de foros que viabilizassem condições para a efetiva participação e controle da sociedade sobre as questões relativas à saúde.

Nesse mesmo período, a política de recursos humanos entāo desenvolvida já afligia as entidades representativas dos profissionais da saúde. As entidades médicas, particularmente, apontavam vários problemas enfrentados pela categoria com relação às condiçōes de trabalho - deterioração da área física, sucateamento e/ou falta de equipamentos e recursos humanos - e à remuneração.

Em decorrência do boom resultante da desenfreada abertura de escolas médicas na década de 70 , houve exagerado aumento de profissionais no mercado com formação inadequada, em conseqüência da má estruturaçăo curricular das escolas. Para agravar o quadro, ocorreu também intensa concentração desses profissionais em determinadas áreas geográficas, resultado da péssima distribuição dos serviços de saúde no País.

Os anos 80 caracterizaram-se pela divisão do mercado de trabalho - público assalariado ou conveniado - e pela crescente expansão dos planos privados de assistência que, através do credenciamento de profissionais, representou para os médicos a perda de sua prática liberal. Assim, a figura do intermediário do trabalho médico implicou a perda crescente da autonomia do exercício profissional e a generalizada baixa remuneração.

Após essa regressão histórica, salientamos que o presente livro, documentário de um relato da categoria médica na década de 90 , não só fornece dados quantitativos da totalidade e distribuição dos médicos no Brasil, mas também revela o expressivo perfil de juventude desses profissionais e demonstra inequivocamente a crescente presença das mulheres na profissão, sobretudo nas faixas etárias mais jovens. Tal fato, certamente, requer maior reflexão, haja vista que este universo de profissionais exigirá, em futuro próximo, mudanças na organização dos serviços, pois a muIher mantém menor número de vínculos empregatícios e mostra tendência de vocação para áreas da medicina diferentes daquelas escolhidas pelos homens, o que gerará demandas e necessidades de novas políticas para a área da saúde.

É também apontado no livro o modo como vem ocorrendo a formaçāo dos médicos na graduação e pós-graduaçăo lato sensu, bem como a busca pela especialização e as dificuldades para a manutenção de conhecimentos atualizados.

O mercado de trabalho, ponto alto deste estudo, reflete as variadas políticas que se inter-relacionam na questão saúde, como, por exemplo, a formação de recursos humanos, a prestação de serviços de saúde, a incorporação de novas tecnologias e o próprio desenvolvimento sócio-econômico da nação. Como resultado, observa-se que a interação desses fatores determinou um perfil de profissional que tem, pelo menos, três vínculos de trabalho, percebendo uma remuneração muito baixa, o que dificulta sobremaneira uma adequada sobrevivência profissional e reflete-se de modo negativo na qualidade da assistência médica prestada à população.

Todas as complexidades e dificuldades do exercício profissional estão consolidadas no capítulo que analisa o desgaste do trabalho médico, onde a categoria reve- 
la suas desconfianças com relação ao sistema e às instituições de saúde, quer sejam públicas ou privadas, demonstrando, ao mesmo tempo, sua impotência e desesperança em corrigir trajetórias e recuperar conquistas.

Seqüencialmente, são apresentados dados sobre os médicos e suas vidas políticas intracorporação, avaliando-se aspectos que estão implícitos em suas atuações éticas e na organização sindical, permitindo a percepção de que grande parcela da categoria tem introjetado bandeiras das suas entidades representativas e, até mesmo, possibilitando verificar que uma parcela menor - mas não menos importante mostra-se alienada e até refratária ao ideário das organizaçōes médicas.

A publicação finda com amplas consideraçōes sobre a política de recursos humanos para o Sistema Único de Saúde (SUS), o principal objetivo desta pesquisa, e visa a desencadear a discussăo não apenas entre os médicos, mas sobretudo com a sociedade, com o objetivo de viabilizar exercício profissional mais adequado, condigno e, obviamente, conseqüente melhoria na atenção à saúde.

Finalizando, cabe-nos manifestar os mais sinceros agradecimentos aos médicos que colaboraram com a pesquisa e, particularmente, à equipe de pesquisadores da Fundação Oswaldo Cruz, sem os quais esta publicação não viria a lume. Esperamos que, diante das expectativas depositadas, a mesma seja um instrumento que propicie uma análise acurada da real situação vivenciada pela comunidade médica, e que os responsáveis pelas políticas de saúde a utilizem para sanar - ou minorar - o grave quadro ora espelhado.

Waldir Paiva Mesquita

Presidente do Conselho Federal de Medicina 



\section{APRESENTAÇĀO}

A Revolução Industrial e a consolidação do sistema capitalista criaram novas áreas de práticas e novos papéis ocupacionais. A aplicação da ciência no mundo industrial e em quase toda a vida humana provocou mudanças substantivas nas bases cognitivas da divisão social do trabalho. A produção de novos conhecimentos e a criação de áreas especializadas possibilitaram o surgimento de inúmeras ocupaçōes que passaram a requerer para si o domínio e, conseqüentemente, o monopólio do conhecimento e sua aplicação através da produção de serviços especializados.

O setor saúde e, especialmente, o mercado de trabalho dos médicos está inserido nessa perspectiva de 'profissionalismo' com oferta de serviços altamente especializados. A medicina é um exemplo típico de uma profissão que conseguiu, de forma espetacular, desenvolver sólida base cognitiva, bem como exclusivo e vasto mercado de trabalho com forte credibilidade social. Tal projeto profissional foi consolidado graças à estreita relação entre as reivindicaçōes da corporação e o apoio do Estado.

A profissăo médica é singular. Nenhuma outra profissão do mundo ocidental adquiriu tanto poder em definir realidades como a medicina o fez ao longo de sua história. Aos médicos é dado o poder de definir, por exemplo, o que é saúde $\mathrm{e}$ doença, o que é sanidade ou insanidade mental; enfim, a eles é conferida a prerrogativa de elaborar e executar critérios de saúde e doença, transformando-se em paradigmas médico-sociais. Ademais, é uma profissão de consulta, com controle dos critérios que qualificam as pessoas que vão atuar na cura.

Em sua história, a medicina construiu sólido conhecimento científico e reivindicou para si o monopólio da cura. Dotada de princípios ético-morais, a atividade médica estabelece singular relação com o consumidor (paciente) de seus serviços, que requer confiança, sigilo e credibilidade.

No entanto, esta poderosa corporação tem sofrido abalos constitutivos na profissão, como, por exemplo, a perda de autonomia, do poder monopolista, do 
ideal de serviço etc. Hoje, o debate gira em torno de questões como a deterioração das condiçōes de trabalho, o assalariamento crescente, o reordenamento do processo de trabalho, a incorporação de outros profissionais na equipe de saúde, bem como o fenômeno da sindicalização dos profissionais de saúde. Também o poder e o saber médicos estão sendo, de certa forma, questionados e partilhados com outros profissionais da área (psicólogos, enfermeiros, nutricionistas, fisioterapeutas etc.), e até mesmo com os engenheiros biomédicos e os técnicos que lidam com sofisticados instrumentos computadorizados, utilizados em salas de cirurgias ou em delicados diagnósticos, procedimentos e terapêuticas.

Atualmente, crescem as análises sociológicas que assinalam as transformações significativas por que passa a medicina e que vêm afetando nuclearmente sua essência profissional. A erosão da autonomia através do assalariamento progressivo da categoria, da visível interferência das políticas públicas de saúde na dinâmica do mercado, da presença acentuada e crescente das megacorporaçōes de saúde no setor, assim como dos avanços tecnológicos que ampliam infinitamente as possibilidades das ciências médicas, vêm afetando a prática profissional dessa categoria e sua autonomia. Tais avanços propiciam poder e diversificação interna, traduzidos no aparecimento de novas especialidades e subespecialidades sofisticadas.

Apesar de essas novas especializações produzirem efeitos positivos na credibilidade social (precisão diagnóstica, tratamento e prognósticos médicos), levam, por outro lado, a uma progressiva dependência do médico a técnicas e recursos mais sofisticados. Esses progressos, na área de apoio ao diagnóstico, vêm promovendo silenciosa transformação na conduta desses profissionais e, em especial, na sua aprendizagem. Cada vez mais diminui a atençăo dada à anamnese e ao apurado exame físico, ocasionando, assim, progressivo abandono de alguns procedimentos que já foram habituais e indispensáveis na construçāo das hipóteses diagnósticas.

É fato também que essas tecnologias são desenvolvidas e controladas não só pela medicina, mas também por outras profissões como a engenharia, a computação, a química, a física etc., provocando abalos na soberania médica.

Novas descobertas na área da genética (seres vivos gerados em laboratórios após manipulação genética, por exemplo), avanços tecnológicos que impedem a morte de pacientes que não sobreviveriam após a retirada do apoio desses recursos, produção de órgãos artificiais e de bebês de proveta, entre outros, adicionam questōes cruciais na redefinição da ética médica. O próprio conceito de responsabilidade tem sua abrangência ampliada, passando a incluir não só a dos médicos, mas a de toda a comunidade científica. A bioética surge neste cenário questionando valores e, simultaneamente, ampliando os limites da ética aplicada à saúde. Desafios da modernidade, tais como AIDS, câncer e guerra bacteriológica, colocam a medicina em situação de extrema vulnerabilidade diante dos limites de sua capacidade de 'curar'. Recentes pesquisas de opinião realizadas no País atestam o crescente descontentamento da população com os serviços de saúde e apontam a prática médica 
como objeto central de suas críticas. Os médicos são, assim, alvo de queixas, críticas, acusações e, por vezes, de processos éticos nos Conselhos Profissionais.

Este livro apresenta uma abordagem sociológica da profissão médica a partir do material empírico da pesquisa "Perfil dos Médicos no Brasil". Optou-se por uma análise no campo da sociologia das profissōes, que permite tratar a medicina como uma singular atividade humana profissionalizada.

No capítulo 1 mostra-se como a profissão médica é tipicamente detentora de elevada autonomia técnica (saber) e econômica (mercado de trabalho), tornando-se uma profissão auto-regulada, com elevado e complexo corpo de conhecimento científico e controle sobre o processo de trabalho. Aborda-se também, nesse capítulo, as alterações não só na base cognitiva (especialização) como também nas relações de trocas que ocorrem no mundo do trabalho. Outras importantes alterações, como o rejuvenescimento, a urbanização e a feminilização também estão aí contempladas.

Um dos determinantes da qualidade dos serviços prestados pelos médicos vincula-se às características de sua formação profissional básica e às possibilidades de obter acesso à educação continuada. Se é verdade que a crescente especialização da medicina na Brasil é sustentada pelo mito da eficácia e racionalidade técnica, por outro lado, incrementa-se a precoce especialização do aspirante à medicina. Estes são os temas centrais de que trata o capítulo 2 .

No capítulo 3, demonstra-se como se constitui o mercado de serviços médicos, bem como a estrutura e a capacidade instalada do sistema de saúde. Ressalta-se também que o mercado de trabalho médico apresenta características específicas, entre outras, o fato de os setores público e privado, bem como o consultório, assumirem papel de importância similar.

A análise do mercado de trabalho médico desenvolvida leva em conta o fato de que tanto a atividade em si como o processo de trabalho têm uma natureza múltipla, ou seja, os médicos de um modo geral atuam em várias instituiçōes de saúde. As mudanças estruturais ocorridas nestas últimas décadas no mercado de trabalho em saúde provocaram redefiniçōes nas formas de inserção do médico, criando uma diversidade muito grande de formas e vínculos de trabalho. Associar mercado de trabalho com estas questões mais amplas, bem como relacioná-lo com o movimento 'geracional' dos médicos especialistas é o tema central do capítulo 4 .

O capítulo 5 analisa a grande transformação social e demográfica do mercado de trabalho médico: a feminilização. A profissão médica sempre foi tradicionalmente exercida por homens; só muito recentemente, a partir da década de 60 , é que se assiste à inserção feminina nessa prática. Nesse capítulo mostra-se que tal inserçáo não se dá sem conflitos e preconceitos sociais.

Como se aborda no capítulo 6, a atividade médica é por natureza desgastante, pelo fato de lidar com vidas freqüentemente em situação de fragilidade, exigindo decisōes rápidas, que muitas vezes envolvem riscos vitais ou mesmo intervenções 
clínicas e cirúrgicas. Esse fato torna o médico mais propenso a sentir-se, ao longo de sua vida profissional, desgastado física e psicologicamente.

Constitui o tema central do capítulo 7 a perda da condição de profissional liberal que tem levado muitos médicos a buscar as entidades sindicais como abrigo para proteger-lhes os direitos trabalhistas. Tentando preservar a soberania médica no mundo do trabalho, os médicos têm-se organizado crescentemente de forma mais coletiva, visando a resgatar a auto-imagem.

As opiniōes sobre o futuro da profissão, bem como a visāo que os médicos têm do Sistema de Saúde brasileiro apontam para assuntos de extrema importância na formulação de políticas adequadas de recursos humanos. À guisa de conclusão, o capítulo 8 aborda questóes referentes às políticas de recursos humanos, envolvendo os aspectos cruciais que hoje determinam a vida e a carreira do médico.

Um anexo contempla os aspectos metodológicos da pesquisa "Perfil dos Médicos no Brasil", cujos dados săo analisados neste livro.

Para finalizar, gostaríamos de fazer alguns agradecimentos.

Aos dirigentes das entidades médicas envolvidas: Conselho Federal de Medicina, Associação Médica Brasileira e Federação Nacional dos Médicos, que depositaram total confiança e enorme crédito a nós, pesquisadores da Fundaçăo Oswaldo Cruz, mostrando como é possível aliar os interesses da academia aos interesses políticos destas entidades. Com igual entusiasmo, agradeço ao Ministério da Saúde, que acreditou nesta aliança.

Especialmente aos conselheiros médicos: Regina Parizi Carvalho, Antônio Henrique Pedrosa Neto e José Cássio de Moraes que, na condução da pesquisa, se destacaram no apoio, na atenção e na solidariedade, revelando-se pessoas indispensáveis ao sucesso deste trabalho, a nossa gratidão.

Prestamos ainda sincero reconhecimento a Crescêncio Antunes, médico, ex-conselheiro, artifície primeiro da pesquisa.

A área de Recursos Humanos em Saúde no Brasil adquiriu, nestas últimas décadas, grande destaque e crescente prestígio acadêmico. Tornou-se um campo em que o trabalho e a amizade vêm-se fundindo em uma agradável relação de cooperação. Sem desmerecer os demais colegas, agradecemos, em especial, aos bons amigos Paulo Buss, Roberto Nogueira, José Paranaguá de Santana, Joana Azevedo, Sábado Cirardi, Francisco Campos, Neuza Moysés e Ana Luiza Stiebler que sabiamente nos mostraram como era importante assumir este desafio acadêmico. E também a Mariza Palácios, médica do trabalho, que prestou colaboração fundamental para entender o estresse e o desgaste médico.

Torna-se difícil expressar o profundo agradecimento ao apoio institucional recebido da Fundação Oswaldo Cruz, principalmente da Escola Nacional de Saúde Pública, que acolheu o projeto e propiciou toda a infra-estrutura para a realizaçāo da pesquisa e, posteriormente, a do livro. 
Com especial carinho e reconhecimento pelo trabalho realizado durante o desenvolvimento da pesquisa "Perfil dos Médicos no Brasil", agradeço às sociólogas Márcia Teixeira e Monica Vieira.

À Editora Fiocruz - especialmente à professora Maria Cecília Minayo e a João Carlos Canossa P. Mendes, coordenador executivo - e à respectiva equipe envolvida no projeto editorial e gráfico desta publicação por não medirem esforços em torná-la uma realidade.

$\mathrm{Na}$ verdade, assumimos a tarefa e o desafio de escrever este livro porque contamos com um conjunto de profissionais dedicados, competentes e com enorme senso de responsabilidade. Com o objetivo de valorizar e dar visibilidade ao trabatho desta equipe, assumimos este outro difícil desafio: escrever um livro com tantas mãos. $O$ resultado foi frutífero e enriquecedor para todos nós.

Maria Helena Machado 


\section{CARACTERISTICAS SOCIOLÓGICAS DA PROFISSÃO MÉDICA}

\section{UMA VISÃO SOCIOLÓGICA DA PROFISSĀO MÉDICA}

Utilizando o conceito de Starr (1991), podemos afirmar que uma profissāo é uma ocupaçăo auto-regulada, que exerce uma atividade especializada, fundamentada numa capacitação ou formação específica, com forte orientação para o ideal de servir à coletividade, norteada por princípios ético-profissionais definidos por ela mesma. ${ }^{1}$ Portanto, a noção de profissão está intrinsecamente vinculada à idéia de uma atividade humana que, mediante conhecimento especializado, atua em determinada realidade, visando interpretá-la, modificá-la, transformá-la para um determinado 'fim social' . A auto-regulação e a autonomia prevalecem nesta relação, e são estes dois elementos que permitem que a profissão tenha a 'autonomia' para recriar realidades.

"Nenhuma outra profissāo exercita este poder na escala em que o faz a medicina, certamente porque nenhuma outra profissão se iguala a ela no grau de autonomia ou auto-regulaçāo", afirma Machado (1996:32). A profissāo médica é este estereótipo de profissāo com alto grau de autonomia técnica (saber) e econômica (mercado de trabalho). Em outros termos, uma profissão auto-regulada, com elevado e complexo corpo de conhecimento científico e controle sobre o processo de trabatho. Na opinião de Freidson (1978), a medicina é, por natureza, uma profissão de consulta, como poucas no mundo contemporâneo. ${ }^{2}$

1 Para mais críticas, consultar a obra de STARR (1991), na qual ele expōe a conformação da profissāo médica nos Estados Unidos utilizada no construto teórico da Sociologia das Profissōes. Sobre este tema especificamente, ver a primeira parte: "Una profesión soberana: el encumbramiento de la autoridad médica", p.17-44.

2 Ver Freirson (1978), que, na década de 70, desenvolveu uma elaborada teoria sobre as profissóes, particularmente sobre a profissão médica. 
De forma sucinta, podemos dizer que a medicina possui algumas prerrogativas monopolistas que a diferenciam da maioria das profissōes que disputam o mercado de serviços especializados. Ela tem, por exemplo, um projeto profissional bemsucedido, no qual, ao longo de sua história, fez uma notável aliança com o Estado (concedendo-lhe prerrogativas legais para seu exercício exclusivo) e com a elite (vendendo-lhe serviços particulares a preço de mercado). Ao longo de sua história, adquiriu um vasto, sólido e complexo conhecimento empírico e científico, transformando sua prática num sofisticado e complexo ato técnico-científico. A idéia do expert tornou-se, no caso da medicina, uma realidade incontestável.

Portanto, a atividade médica no mundo contemporâneo, numa visăo weberiana, é, por definição, uma ação racional, justificada pelas ações que săo orientadas por objetivos claramente formulados e pela escolha dos meios mais adequados para atingir o objetivo proposto. À doença aplica-se o conhecimento médico para esclarecer e desvendar causas, definir diagnósticos e terapêuticas, assim como prognósticos. Num dado momento, esta expertise tornou-se exclusiva do exercício dos experts. Assim, os médicos adquiriram, historicamente, o monopólio de praticar a medicina de forma exclusiva, colocando na ilegalidade e clandestinidade todos os praticantes empíricos e curiosos desse ofício.

Advém daí a autonomia técnica e econômica, fundamento da prática liberal. Ter liberdade de pensar, de agir e de estipular o valor monetário de seus serviços é o preceito fundamental de uma típica atividade liberal. E a medicina se enquadra neste tipo ideal-liberal. Da mesma forma, a autoridade profissional acaba por definir a relaçāo produtor-consumidor.

Quase sempre, prevalece a opinião do médico. Da mesma forma, para que esta autoridade seja exercida com toda a sua força, é necessário que haja um alto grau de legitimidade dos dois lados - tanto do que manda quanto daquele que obedece. $O$ sistema de dominação será tanto mais eficaz quanto maior a sua legitimidade. É preciso, afirma Weber, que as pessoas aceitem e reconheçam a autoridade, o poder e, conseqüentemente, admitam a dominação. ${ }^{3}$ A lógica da confiança, da credibilidade ético-profissional assume feiçōes marcantes e definitivas na relação médico-paciente. Ainda mais importante é o fato de que o médico não só tem autoridade profissional sobre o paciente, mas, principalmente, exerce um real e forte poder de ação sobre ele, tornando-o um consumidor passivo, pouco à vontade para decidir sobre condutas independentes da opiniāo de seu médico. Serviços com esta natureza e características são, em nossa sociedade, oferecidos por poucos profissionais. A engenharia, a advocacia e a odontologia são alguns raros exemplos assemelhados aos serviços especializados oferecidos pela medicina. Além disso, esta lida com um fato importante: sua matéria-prima - o cliente - é subjetiva, o que, na prática, torna cada caso um caso.

3 Ver em Weber (1982) o capítulo "A ciência como vocação", que trata da discussão sobre a autoridade, a ética e a autonomia profissionais. 
O ofício da artesania se confunde com os procedimentos altamente tecnificados que a maioria dos atos médicos dos tempos pós-revolução científica têm requerido.

\section{AUTONOMIA PROFISSIONAL}

Estudos realizados por Freidson (1978), Larson (1977), Starr (1991), Schraiber (1993), Ribeiro (1995) e Machado (1996) sugerem uma convergência no debate sobre a autonomia do trabalho médico. Estes autores adotam a premissa de que, no trabalho médico, é imprescindível a liberdade de ação, a autonomia de decidir a conduta técnica que melhor se adapte à necessidade do cliente. Adotando a definição de autonomia como a capacidade de tomar decisōes por conta própria, observamos que ela constitui um valor em si mesmo para a profissão médica. Tanto no que se refere ao saber como ao ato em si (sua apropriação), a autonomia é um elemento-chave para entender o complexo mundo médico. Quase sempre, com base na premissa de que cada caso é um caso, os médicos são levados a tomar decisões independentes, em muitos casos contrariando interesses ambientais - sejam eles institucionais ou sociais - e até mesmo interesses políticos, vinculados ao Estado.

Afirma Machado (1996:59):

os profissionais - advogados, médicos, arquitetos, engenheiros, odontólogos etc. - constituem uma parcela pequena do setor de serviços. Trata-se, contudo, de uma fraçăo estratégica na qual se concentra, no dizer de Perkin, 'a criatividade humana sob a forma de expertise especializada', que inventa e instala tecnologia (...). No segmento profissional encontra-se a divisão do trabalho elevado ao mais alto grau de perícia e inteligência aplicada. Por isso, Perkin chama de 'sociedades profissionais' as sociedades pós-industriais.

Na profissão médica, essa capacidade de auto-regular o próprio trabalho é fruto da medicina moderna, do século XX. Para tanto, a profissão médica buscou: primeiro, produzir crédito social, validando seus serviços como 'bens sociais' capazes de promover o desenvolvimento social da coletividade; segundo, fundar seu conhecimento e sua prática profissional na racionalidade científica; terceiro, basear a autoridade técnica do médico na expertise técnica, no conhecimento especializado, da mesma forma que seu trabalho tem, em si mesmo, um forte apelo ético, alicerçado em um código de atitudes profissionais que rege o ato médico. Enfim, podemos dizer que a unificação da base cognitiva produziu a unificação do saber, do conhecimento médico, padronizando tanto a produção de serviços (assistência médica) como os produtores (médicos). Por outro lado, embora o conhecimento médico seja produzido socialmente, sua apropriação, paradoxalmente, é privada. A profissão médica arquitetou estratégias profissionais que são elementos pré-capitalistas, de antimercado, os quais atuam na proteção e manutenção de prerrogativas monopolistas. Em outras palavras, o domí- 
nio e o monopólio desse conhecimento constituem o fundamento da autonomia das profissóes e do prestígio profissional (Larson, 1977). ${ }^{4}$

O fato de a medicina, nos tempos atuais, configurar-se como uma profissão de grande sucesso profissional e de reconhecimento em todo o mundo a torna uma profissão de alta adesão de seus membros ao projeto profissional, o que significa dizer que, uma vez médico, raramente abandona-se o ofício. A medicina como ofício de curar é uma atividade que não somente requer o apelo de lidar com pessoas, como evoca uma grande capacidade de persistência ao longo da formação profissional. Tornar-se médico significa estar em processo de formação (nível formal e obrigatório) por cerca de vinte anos. Em boa parte, o sucesso do projeto profissional pode ser explicado por essa adesão dos membros à vida profissional. Poucas são as profissóes em que o mundo do trabalho se funde e, por vezes, se confunde com o mundo da vida.

\section{O MERCADO DE SERVIÇOS ESPECIALLZADOS: A CONSTITUIÇÃO DO MONOPÓLIO}

Ao abordarmos o tema mercado de trabalho, invariavelmente nos reportamos a seus elementos fundadores: a) profissionalismo dos serviços prestados; b) garantias legais e monopolistas de prática profissional; c) clientela ilimitada, cativa, exclusiva; d) leis regulatórias da prática profissional, regulando inclusive o valor dos serviços oferecidos. A medicina - tal como a advocacia, a engenharia e a arquitetura, por exemplo - anuncia, no século $X X$, serviços especializados, estandardizados e com elevada credibilidade social.

Como já afirmamos, a medicina de nossos tempos é um exemplo típico de um projeto bem-sucedido, no qual a aliança entre o Estado e a elite produziu efeitos positivos no futuro da profissão. Afirma Machado (1996:54-55): "enfim, a medicina científica anuncia-se no nosso século sem concorrentes, com forte controle do mercado e do sistema de produção e transmissão de sua base cognitiva". Ela recupera, também, de sua fase pré-capitalista, os elementos ideológicos necessários para fortalecer a legitimidade de sua autoridade cultural e social, tais como o 'ideal de serviço', ética, autonomia etc. Mesmo em países como a França, ${ }^{5}$ de forte tradiçăo intervencionista estatal, a medicina obteve um alto grau de autonomia, negociando o predomínio da forma 'liberal' de exercício profissional. Todos esses elementos fizeram dela uma profissão altamente bem-sucedida em seu projeto de controle do mercado, de obtenção de prestígio social e de vantagens na estrutura ocupacional.

Para além dos elementos estruturais já mencionados (unidade cognitiva, padronização dos serviços etc.), esse sucesso foi possível graças à conjugação de quatro

4 LARSON (1977), especialmente nos capítulos 1 a 5, desenvolve alentada discussão sobre autonomia profissional e mercado de trabalho.

5 Sobre este tema, ver o artigo de COELHO (1995). 
fatores empíricos cruciais: a) relevância do valor para o qual os serviços médicos estão orientados; b) capacidade 'quase ilimitada' de expansão do mercado de serviços de saúde; c) inclinaçăo natural do Estado para dar suporte e oferecer vantagens monopolistas a uma atividade profissional fundamental ao bem-estar dos cidadāos; e d) a peculiar falta de organização da clientela.

Sendo a profissão médica uma das poucas ocupações do mundo contemporâneo que adquiriu tais regalias e privilégios de mercado, a prática exercida por pessoas não habilitadas (sem diploma) é reconhecida pela justiça como charlatanismo, prática ilegal passivel de penalidades. Mais do que isso, a profissão médica desenvolveu mecanismos fortemente ideológicos, que fizeram com que os médicos passassem a ser considerados e reconhecidos como profissionais essenciais ao sistema de saúde. A estreita identificação e correlação entre os médicos e o sistema de saúde responsabilizando estes profissionais pela qualidade da assistência prestada - não é mera casualidade nem uma associação ingênua da sociedade. Tal fato não resulta do imaginário popular, mas de uma complexa e engenhosa construção social, que delega à profissão médica o papel definidor das políticas de saúde. Estudos recentes de Mechanic (1991) apontam para uma interpretação dos fatos históricos ocorridos com a profissão médica nestas últimas décadas, mostrando que não só a medicina como a profissão têm acumulado prestígio e poder. Na opinião desse autor, ocorreu uma grande transformação na atividade médica no pós-guerra, quando a medicina se impôs como uma das atividades mais importantes da economia dos Estados Unidos. Para ele, os avanços tecnológicos ao mesmo tempo em que abriram novos mercados, inclusive novas especialidades e novas profissões, produziram também um acúmulo considerável de poder de decisão nas mãos dos médicos, da profissão médica, no que se refere à formulação de políticas de saúde. Aos médicos, o poder da saúde. Como veremos mais adiante, essas questões são de importância preponderante na forma como os médicos brasileiros experimentam hoje a crise do Sistema de Saúde no seu cotidiano.

\section{A PROFISSÃO MÉDICA: ALGUNS DILEMAS NO FINAL DO SÉCULO XX}

\section{A especializaçōo}

A revolução científica, fruto dos séculos $X I X$ e $X X$, permitiu grandes avanços no campo das ciências médicas. $O$ conhecimento médico $e$, conseqüentemente, a prática profissional adquiriram feições científicas, imprimindo a racionalidade objetiva como fundamento de um novo paradigma médico. O pensamento e o ato médicos fundiram-se numa complexa combinação de empirismo, experiência cotidiana e raciocínio clínico. A consulta, a anamnese e a análise clínica passaram a ser a conduta-padrão de um bom médico, dando-lhe poder, prestígio e crédito junto ao paciente. Esse poder assume também feições econômicas. Em quase todo o mundo oci- 
dental, em especial nos países desenvolvidos, a atividade médica é uma das atividades mais rendosas entre os profissionais white-collars.

O processo de divisão social do trabalho médico, com o advento da revolução científica, é fato reconhecido em todo o mundo. O conhecimento e a prática da medicina tornaram-se tão complexos que a divisão do trabalho médico se impôs. $O$ processo de especialização é um traço característico dessa nova ordem racionalizadora. Desta forma,

a concepção de uma nova prática médica determinou em grande parte as mudanças substantivas na atividade, compreendendo os aspectos técnicos e práticos. Essa nova abordagem da medicina levou a uma redefinição de parâmetros e critérios tanto na inserçăo da profissăo no mundo do trabalho, como na própria atuação deste profissional no processo de trabalho em saúde. (Machado et al., 1995:5)

Estudos sociológicos mostram que os avanços tecnológicos têm contribuído fortemente para o surgimento de novas especialidades e subespecialidades. Até há alguns anos, a sociedade não contava com médicos especializados em unidades intensivas, em diagnósticos de imagens (ultra-sonografia, ressonância magnética, mamografia, entre outros) ou mesmo com o desenvolvimento da oftalmologia, que se transformou numa atividade altamente tecnificada. Da mesma forma, com o desenvolvimento dos diagnósticos das doenças do coração, por exemplo, várias subespecialidades passaram a vigorar no quadro dos serviços altamente especializados oferecidos ao consumidor, tais como exames coronários específicos que detectam preventivamente inúmeros problemas cardíacos, eliminando, inclusive, procedimentos cirúrgicos. Estudos realizados por Díaz-Jouanen (1990) mostram que o fenômeno da especialização pode ser analisado sob vários ângulos. Segundo esse autor, as especialidades médicas podem ser classificadas em três grandes grupos sociológicos: as 'cognitivas' (clínica médica, pediatria etc.); as 'técnicas' ou de 'habilidades' (especialidades cirúrgicas) e as 'intermediárias' (cardiologia, gastroenterologia etc.). Tal classificação está associada ao grau de envolvimento que o profissional estabelece com o paciente, sugerindo que as especialidades que exigem maior contato pessoal são as ditas cognitivas, em oposição às especialidades técnicas ou de habilidades, nas quais há predomínio de atos médicos respaldados em apoio diagnóstico que envolve alta tecnologia e pouco contato pessoal com o paciente.

Utilizando o modelo de Díaz-Jouanen e buscando redefinir e reclassificar sociologicamente as especialidades médicas, adotamos uma nova abordagem considerando a natureza e o processo de trabalho médico (Quadro 1.1).

Assim, propomos:

a) Especialidades cognitivas - lidam diretamente com o cliente, e sua relação profissional se baseia fundamentalmente no conhecimento cognitivo adquirido nas escolas médicas. O raciocínio clínico é acentuadamente valorizado e a relação subjetiva tende a ser mais enfatizada. A tradição do médico-físico dos primórdios da medicina é aqui assegurada por meio de uma medicina exercida de modo arte- 
sanal. Exemplos desta tipologia são os clínicos gerais (medicina interna), os pediatras, os psiquiatras, os cardiologistas, os geriatras, os homeopatas, que, no mundo pós-moderno, assumem cada vez mais o papel de 'aconseIhador' do modo de vida do paciente, indo muito além de seu papel estritamente técnico.

b) Especialidades técnico-cirúrgicas e de habilidades - também lidam diretamente com o paciente, mas não de forma tão direta e cotidiana, como ocorre com os 'médicos cognitivos'. Neste caso, a relação médico-paciente é tendencialmente burocratizada, padronizada e, quase sempre, programada. Neste caso, o que predomina no processo de trabalho é o conhecimento técnico, ou seja, habilidades técnicas inerentes ao ato em si, quase sempre de forma pontual e precisa. Freqüentemente, estas intervenções (em sua maioria cirúrgicas) exigem apoio de diagnósticos - clínicos, radiológicos ou laboratoriais. A relação médico-paciente é mediada por equipes de apoio e de equipamentos sofisticados, que auxiliam na conduta e nos procedimentos. A tradição do boticário dos primórdios da medicina é depositada nas diversas especialidades cirúrgicas que conformam esta tipologia: cirurgiōes gerais, cardiovasculares, plásticos etc.

c) Especialidades intermediárias - são as especialidades ou áreas da prática médica que associam mais estreitamente as habilidades técnicas (cirurgia) à base cognitiva das ciências médicas (clínica), intermediando essas duas áreas distintas. Tais especialidades rompem com as barreiras desses dois mundos aparentemente isolados: o mundo dos clínicos - antigos físicos - e o dos cirurgiōes - boticários da era pré-científica. Não há, nesses casos, predominância da técnica ou da validação da base cognitiva. Formando verdadeiras 'clínicas autônomas' estão aquelas especialidades que possuem esta autonomia de processo de trabalho, o que significa dizer que sua atividade condensa os dois ramos básicos da medicina, dispensando quase sempre interferências de colegas especialistas para a finalização do diagnóstico e intervenção. Enquadram-se nesta modalidade oftalmologistas, ortopedistas e traumatologistas, gineco-obstetras, gastroenterologistas e otorrinolaringologistas, por exemplo.

d) Especialidades tecnológicas e/ou burocráticas - adotam regularmente a padronização no processo de trabalho, com alto controle burocrático. A relação médicopaciente, de natureza individual e intransferível, cede lugar à relação coletiva, na qual o objeto é quase sempre impessoal, referindo-se a populações, a coletividades ou até a um paciente de um colega que necessite de algum exame específico. São especialidades tipicamente urbanas, fruto de processos sociais mais avançados e voltados à pesquisa, diagnósticos laboratoriais, gerência, administração e planejamento em saúde, desenvolvidos em organizações complexas. Enquadram-se nesta modalidade, dentre outros, administradores hospitalares, epidemiologistas, sanitaristas, médicos do tráfego, patologistas e radiologistas. 


\section{Quadro 1.1 - Classificação das especialidades médicas*}

\begin{tabular}{|c|c|c|c|}
\hline GRUPO 1 & GRUPO 2 & GRUPO 3 & GRUPO 4 \\
\hline Cognitivas & $\begin{array}{c}\text { Técnico-cirúrgicas e de } \\
\text { Habilidades }\end{array}$ & Intermediárias & $\begin{array}{c}\text { Tecnológicas e } \\
\text { Burocráticas }\end{array}$ \\
\hline Alergia e Imunoterapia & Cirurgia cardiovascular & Acupuntura & Adm. Hospitalar \\
\hline Angiologia & Cirurgia da mão & Anestesiologia & Citopatologia \\
\hline Cardiologia & Cir. de cabeça e pescoço & Broncoesofagologia & Eletroencefalografia \\
\hline Endocrinologia c Metabolia & Cirurgia geral & Cancerologia & Hemoterapia \\
\hline Foniatria & Cirurgia pediátrica & Dermatologia & Medicina do trátego \\
\hline Geriatria e Cerontologia & Cirurgia plásticar & Endoscopia digestiva & Medicina nuclear \\
\hline Genética clínica & Cirurgia torácica & Fisiatria & Medicina sanitáriè \\
\hline Hansenologia & Cirurgid vascular & Castroenterologia & Neurofisiologia clínica \\
\hline Homeopatia & Mastologia & Ginecologia & Patologia \\
\hline Infectologia & Neurocirurgia & Obstetricia & Patologia clínica \\
\hline Medicina do trabalho & & Hemalologia & Radiologia \\
\hline Medicina esportiva & & Nefrologia & Radioterapisi \\
\hline Med. geral comunitária & & Medicina legal & \\
\hline Medicina interna & & Ofialmologia & \\
\hline Neurologia & & Ortopedia e Traumatologia & \\
\hline Neurologia pediátrica & & Otorrinotaringologia & \\
\hline Nutrologia & & Proctologia & \\
\hline Pediatria & & Terapia intensiva & \\
\hline Pneumologia & & Urologia & \\
\hline Psicpuiatria & & & \\
\hline Reumatologia & & & \\
\hline Sexologia & & & \\
\hline Tisiologira & & & \\
\hline 23 especiadidades & 10 especialidades & 19 especialidades & 12 especialidadios \\
\hline $\begin{array}{l}35,9 \% \text { das } \\
\text { especialidades }\end{array}$ & $\begin{array}{l}15,6 \% \text { das } \\
\text { especialidades }\end{array}$ & $\begin{array}{l}29,7 \% \text { das } \\
\text { especialidades }\end{array}$ & $\begin{array}{l}18,8 \% \text { das } \\
\text { especialidades }\end{array}$ \\
\hline $\begin{array}{l}76.725 \\
43,3 \% \text { dos médicos }\end{array}$ & $\begin{array}{l}23.511 \\
13,3 \% \text { dos médicos }\end{array}$ & $\begin{array}{l}64.206 \\
36,3 \% \text { dos médicos }\end{array}$ & $\begin{array}{l}12.599 \\
7,1 \% \text { dos médicos }\end{array}$ \\
\hline
\end{tabular}

* Excluíram-se os que nảo declararam a especialidade principal, bem como os que atuam em espccialidades näo reconhecidas pelo CFM.

Fonte: Pesquisa "Pertil dos Médicos no Brasil", Fiocruz/CFM. 
Analisando o Quadro 1.1, das especialidades reconhecidas pelo Conselho Federal de Medicina, notamos um predomínio daquelas que se baseian na relação médico-paciente, ou seja, as 'Cognitivas' (35,9\%), as quais englobam 23 especialidades, com um contingente de quase oitenta mil médicos. Numa segunda ordem de importância, encontram-se as 'Intermediárias' (29,7\%) - Crupo 3 -, que englobam 19 especialidades, totalizando mais de sessenta mil médicos. Em seguida, estão as especialidades do Grupo 2, denominadas 'Técnico-Cirúrgicas e de Habilidades', com dez especialidades, somando pouco mais de 23 mil médicos. Por último, estāo as especialidades 'Tecnológicas e Burocráticas', que, apesar de aglutinar 12 especialidades, somam pouco mais de 12 mil médicos.

Também é significativo o número de especialidades que demandam procedimentos cirúrgicos: 29 das 64 reconhecidas. Chamam igualmente a atenção as espccialidades do Grupo 4, conformando-se, por um lado, naquelas consideradas 'auxiliares' ao diagnóstico e ao ato médico - seja cirúrgico ou clínico -, ou, por outro lado, reforçando e explicitando a institucionalização da saúde (burocratização), como no caso dos administradores hospitalares, por exemplo.

Vale ressaltar também que as especialidades que conformam o mercado de trabalho médico no Brasil não se restringem ao quadro aqui apresentado. Constatamos empiricamente, por meio dos dados da pesquisa, uma variedade de serviços médicos de alta especializaçăo, conformando-se em 'nichos' de mercado de serviços médicos com clientela própria e recorrente. Estamos nos referindo aos médicos especialistas, por exemplo, em distúrbios do sono, em diagnósticos raros, em ultrasonografia, cirurgia de mão, laparoscopia, ecografia, hemodinâmica, entre outros. A realidade do mercado de serviços médicos no Brasil aponta para uma expansão e/ou ramificação do conhecimento médico. Já é muito comum, por exemplo, a existência de algumas subespecialidades oriundas da pediatria, da radiologia, da ortopedia e traumatologia, da cirurgia plástica, da cardiologia etc., as quais constituem micromundos do processo de divisão do trabalho médico.

Como podemos analisar o fenômeno da especializaçāo médica sob uma perspectiva sociológica? Durkheim diria que a divisão social do trabalho é um fenômeno positivo das sociedades modernas, retirando o indivíduo do estado de solidariedade mecânica e fazendo-o estabelecer relaçōes de trocas com os demais, nas quais prevalece a solidariedade orgânica. Assim sendo, a divisão do trabalho supōe que o trabalhador nāo perde de vista seus colegas, mas age sobre eles e sofre sua ação. A interação se dá no processo de trabalho.

Visto sob este ângulo, Durkheim tinha razão em creditar à divisão do trabalho valores positivos, de agregação e solidariedade orgânica.

Por outro lado, autores como Haug (1988), Mckinlay \& Arches (1986) e Oppenheimer $(1970,1975)$, entre outros, ao analisarem o crescimento do fenômeno da especialização em países distintos, mostram que este processo tem conseqüências funestas não só para o processo de trabalho médico, mas, e principalmente, para o sistema de saúde. Machado (1996:181-182) mostra que o 
processo de especialização tem sido um mecanismo estratégico adotado pelas profissöes para manter sob controle os avanços e os novos conhecimentos, de modo a assegurar o monopólio do saber e da prática profissional. Neste sentido, a especialização preserva a autonomia, mas, por outro lado, a perda da dimensão da totalidade é inevitável. Criar ilhas de conhecimento e de práticas profissionais altamente especializadas requer o abandono do conhecimento generalista, globalizante.

Uma conseqüência direta deste processo de especialização é a crescente fragmentação dos saberes e práticas médicas, ou seja, esses segmentos profissionais se isolam e desenvolvem formas organizativas próprias em sociedades distintas, como as de oftalmologistas, anestesistas, pediatras e psiquiatras.

Conclui a autora:

recursos técnico-científicos, até há pouco tempo inimagináveis, passaram a ser usados com freqüencia. No entanto, pelo fato de envolver tecnologia de ponta e grandes investimentos financeiros, esses serviços chegam ao consumo com altos custos para os usuários, 'inacessíveis' para muitos, tornando-se inevitável o agenciamento através de empresas de saúde, convênios e seguros. Este é um dos pontos frágeis da revoluçāo tecnológica produzida nas ciências médicas: medicina complexa, de alta precisão diagnóstica, porém de alto custo operacional e de acesso restrito, tanto para os médicos que utilizam os equipamentos sofisticados, como para os usuários destes serviços. (Machado, 1996:188)

Enfim, a revoluçāo tecnológica do final do século $X X$ tem provocado mudanças significativas tanto nos saberes como nas práticas da profissāo médica. A autonomia técnica, o poder de decisão, a relação médico-paciente, a tradicional hegemonia médica nas equipes de saúde, o domínio e conhecimento globalizante do corpo humano, bem como o prestígio e status quo dos médicos sofreram abalos importantes, alterando não só a dinâmica interna da profissāo como, e especialmente, a nova visão social que a sociedade passa a produzir sobre os médicos em geral.

\section{A institucionalização e a burocratização}

A institucionalização do trabalho médico é outra questão relevante que se vem colocando como um grande desafio político para a profissão, principalmente no que se refere às radicais mudanças no mundo do trabalho. Fenômenos como a burocratização, a segmentação, a rotinização e a padronização dos atos médicos são recorrentes hoje na prática médica em todo o mundo. Cada vez mais o trabalho médico se desenvolve em organizações. Abbott (1988) analisa este fenômeno e mostra como é de fundamental importância nos estudos sociológicos conferir relevância às análises dos ambientes do mundo do trabalho. Da mesma forma, revela uma nova dimensāo para os estudos das profissões: a necessidade de enfocar mais os aspectos organizacionais, ou seja, enfocar o profissional numa dada estrutura organizacional. A medicina de nossos tempos tem suas práticas desenvolvidas predo- 
minantemente em estruturas organizacionais, sejam elas de caráter privado ou público, particular ou coletivo. $O$ envolvimento organizacional é um fato. A medicina se institucionalizou, perdendo, assim, prerrogativas monopolistas até então de grande relevância no cotidiano da prática médica. Isto significa dizer que

a burocratizaçāo e racionalização de procedimentos têm conseqüências significativas sobre $o$ ato médico, que, em princípio, deveria estar livre dos constrangimentos burocráticos típicos dos ambientes empresariais. Na dimensão coletiva da profissão, controles deste tipo levam à erosão da autonomia profissional e à perda dos preceitos éticos que a medicina estabelece como ideal de trabalho. (Machado, 1996:66)

No Brasil, este fenômeno também assume dimensões importantes. Histórica e estruturalmente, o mercado de trabalho do setor público tem se mostrado de grande relevância para os médicos brasileiros. A pesquisa mostra que cerca de $70 \%$ dos médicos têm vínculo de trabalho com tal setor, no âmbito federal, estadual ou municipal. Da mesma forma, poucos são aqueles que, na atualidade, nāo dependem de emprego nas instituições privadas. Em ambos os casos a institucionalização dos serviços médicos é uma realidade, e a racionalizaçāo e, conseqüentemente, a burocratização do processo de trabalho passam a ser uma exigência gerencial.

O empresariamento no setor saúde tem aumentado significativamente nas últimas décadas. Conseqüencia lógica desse processo é a implementação de um sistema burocrático de controle mais eficiente sobre o quadro profissional nessas empresas que vendem serviços de saúde. Trata-se de aperfeiçoar o ajuste entre os objetivos finalisticos dessas organizaçōes - prestar assistência - aos interesses lucrativos. (Machado, 1996:192-193)

Resultado imediato desta nova ordem administrativa

é que a autonomia passa a ser vista mais como uma questão simbólica do que real, já que o médico perde o controle sobre a produçāo, distribuição e preço final do serviço. (p.193)

Se, no passado, honorários médicos, consultas ou cirurgias eram questōes que os médicos tratavam diretamente com o paciente, hoje sāo intermediadas por empresas. Nesta perspectiva, configuram-se dois mundos às vezes irreconciliáveis: o profissional e o organizacional. Como veremos em outro momento, os médicos no Brasil experimentam esta situação.

A institucionalização alcança também os consultórios particulares. Por meio de contratos de prestação de serviços conveniados, produzindo serviços a preços de atacado, os médicos, com freqüência, enfrentam, em seus ambientes particulares, situaçōes constrangedoras de cerceamento e restriçōes burocráticas na relação médico-paciente. Também nestes 'nichos de atuaçăo profissional', aparentemente isentos de interferências externas, os médicos e os pacientes têm enfrentado situações nas quais os interesses de ambos são constantemente contrariados. 
Mesmo estando em seu consultório particular, terá que atender a várias exigências burocráticas - preenchimento de papeletas, formulários, guias especiais - e obedecer a normas e códigos organizacionais de cada convênio. Além do mais, o valor de seus serviços estará predeterminado, nāo sendo permitidas extrapolaçōes e alterações de qualquer ordem. (Machado, 1996:201-202)

\section{ALGUMAS TENDÊNCIAS SÓCIO-DEMOGRÁFICAS}

As mudanças que ocorrem na profissão médica não se referem apenas àquelas observadas na base cognitiva, na capacidade de realizar o trabalho com autonomia ou mesmo nas relações de trocas que se operam no mercado de trabalho. Outras importantes alteraçōes, tais como 'urbanização', 'rejuvenescimento', 'feminilização', estão ocorrendo na profissão, afetando especialmente sua estrutura sócio-demográfica e transformando definitivamente a tipologia do contingente de profissionais que se dedicam à medicina. Convém ressaltar que, ao analisar as tendências sócio-demográficas - e os demais aspectos que este trabalho busca enfocar - experimentadas pela profissão médica no País, estaremos tomando como base os dados obtidos quando da pesquisa "Perfil dos Médicos no Brasil".

\section{Origem do médico: mudanças à vista?}

A medicina é uma profissāo de reconhecida tradição. Há muito tempo que ser médico significa prestígio, status e destaque social, tanto para o núcleo familiar como para a sociedade em geral.

A origem social 'diferenciada' dos médicos é um fato observável especialmente a partir da consolidação da medicina como uma profissão científica, tornando-a uma atividade profissional de futuro próspero. Starr, ao analisar a profissão médica americana, mostra como a posição do médico dependia tanto de seus antecedentes familiares como da posição de seus pacientes e também da natureza de sua ocupação: "o crescimento da ciência foi importantíssimo para o desenvolvimento do profissionalismo" (1991:20).

No entanto, esse prestígio foi construído socialmente ao longo da história. Na verdade, se analisarmos os antecedentes da profissāo médica, iremos encontrar muitos contratempos. Analisa Starr (1991:20):

Em tempos dos romanos, os médicos foram primordialmente escravos, libertos e estrangeiros, e a medicina se constituía em uma ocupação inferior. $\mathrm{Na}$ Inglaterra do século XVIII, embora se situassem acima dos cirurgiões e boticários, os médicos ocuparam apenas uma posição de classe média e tinham que lutar para ter patrocínio dos ricos com a esperança de comprar uma casa ou um título. Na França do século XIX e princípios do século XX, era comum que os médicos fossem pobres e poucos tinham êxito. Conscientes de que a medicina 
era um caminho inadequado para alcançar uma posiçāo elevada, buscavam mais um ideal de cultura geral que um logro profissional.

Coelho (1995) faz uma análise comparativa da constituição da profissāo médica como atividade científica na Inglaterra, na França e nos Estados Unidos, e mostra que, nesses países, até o final do século passado e início deste, a medicina não gozava de reputação e prestígio sociais, só tendo obtido sucesso neste século. Em outras palavras, a

despeito de sua bem-sucedida trajetória institucional, a medicina norte-americana chegou ao nosso século num estágio pré-pragmático. A exemplo de outros países, a cinurgia fizera grandes progressos graças à introdução de novas técnicas, mas a medicina americana năo obteve o monopólio de jure na prestação de serviços médicos. Alguns poucos estados deram proteção legal aos novos sectários (osteopatas, cientistas cristäos, quiropodistas etc.), mas eles já haviam deixado de constituir uma ameaça para a medicina regular. (p. 47)

A história da profissão médica no Brasil também acompanhou essa trajetória social de desprestígio e baixo status. Lycurgo Santos Filho, estudioso do tema, em sua obra sobre a história da profissão médica no Brasil, relata o seguinte:

De humilde condição, simples homens de oficio, por todo o decorrer do século XVI e ainda do XVII, são quase todos judeus, cristāos-novos, ou meio-cristãos os que vêm exercer profissão médico-farmacêutica. Nômades, como costumavam ser na Europa, perambulam de vila em vila, de povoado em povoado. Caminhavam léguas e léguas, chegam aonde não existe outro, a clientela aflui, praticam e ganham algum dinheiro. Ficam até que passe o sabor da novidade um profissional na terra! - e, quando rareiam os fregueses, partem novamente para outra povoação, outro engenho, outras regiöes. Uns tantos empregam-se no serviço dos donatários, dos capitães-generais, dos senhores de engenho. Não passam de criados, senviçais de seu ofício. (Santos Filho, 1991:60-61)

No entanto, o autor admite que havia exceções quanto à posição social:

Foram os 'licenciados' que desempenharam o cargo de físico-mor de Salvador, instituído no governo de Tomé de Souza. Tinham diploma. Possuiam carta de 'licença' e gozaram de certo prestígio, certa consideraçāo. (p.61) ${ }^{6}$

Enfim, decorreu um longo tempo até que a profissão médica tomasse a dimensão social que hoje tem em todo o mundo. Entretanto, com freqüência, os analistas se esquecem dos contratempos que cercaram a história da medicina, cuja história de êxitos é muito recente, fruto dos séculos XIX e XX.

Assim como na tradição do 'artesanato', a boa prática médica está associada à decodificação de casos e 'experiências clínicas' de um longo e minucioso processo de conhecimento e autoconhecimento, prática calcada num empirismo cotidiano

6 Para mais criticas, ver as obras de SAntos Filho (1991), Starr (1991) e Coelho (1995), entre outros, que tratam especificamente da conformação da profissão em diversos palses. 
adquirido no mundo do trabalho. Desde cedo, o médico é levado a buscar experiências empíricas de prática médica. Para alguns autores, esta busca representa a complementação da formação acadêmica oferecida nos bancos universitários.

Essa introdução de um currículo informal e simultâneo é, para os futuros clínicos, a forma de se iniciarem na complicada arte clínica, adquirindo um pouco da experiência clínica pessoal tão necessária para o exercício profissional. (...) os futuros cirurgiōes, de outro lado, buscavam maior habilidade técnica, fixando-se logo nas enfermarias de doentes cirúrgicos e participando em cirurgias como assistentes ou instrumentadores do professor. (Schraiber, 1993:60)

Seguir a profissăo de um membro da família também é uma situação relativamente recente na história médica. Entretanto, este aspecto familiar reforça a característica de artesanato da profissão e o acentuado prestígio que ela adquiriu. Segundo a pesquisa, quase a metade dos médicos declararam ter parente médico, destacando-se primos (30\%), irmãos (27\%), tios (13\%), pais (10\%) e filhos $(6 \%)$. Vale ressaltar que a média de dois parentes médicos que esta subpopulação apresentou é composta pelas figuras do pai e de um irmão. ${ }^{7}$

Em estudos realizados no início dos anos 90 , Schraiber mostra como a escoIha profissional na medicina acompanha a herança familiar. Para a autora, a escolha profissional representa dois caminhos: o da ascensão social ou da continuidade familiar. Assim, a

profissão representa para os indivíduos entrevistados a viabilização do projeto de ascensão social que cada um traz como expectativa de participação na sociedade, de modo a se reconhecerem, e serem reconhecidos, como sujeitos sociais de prestígio e valor. Para alguns pode representar a simples continuidade de uma posição social já conquistada pela família. (...) Doutor Luís, por exemplo, seguiu os passos de seu pai e esperou que seu fitho seguisse os seus. Para ele tratava-se de um caminho natural ... (Schraiber, 1993:49-50) ${ }^{8}$

Os dados da pesquisa sugerem que, no período de 1940 a 1990, ocorreu um crescimento relativo da proporção de profissionais cujos pais e avós são médicos. Ao longo desse período, o número de irmãos médicos cresceu, atingindo percentuais elevados nos profissionais dos anos 70, 80 e 90; igualmente cresceu o número de médicos cujos tios e primos também exercem a profissão (Tabela 1.1).

7 É importante salientar que o mesmo médico podia declarar ter até três parentes médicos, como avós, primos, irmãos, tios, filhos, sobrinhos ou netos, e, obviamente, pai e mãe; portanto, para a construção dessa 'tipologia' (pai/irmão), foram ponderados estes fatores. Para maior compreensão, consultar MACHADO et al. (1996, v.1)

8 Para aprofundar o tema, examinar a obra de SCHraleer (1993) que, utilizando histórias de vidas de médicos nascidos no início do século, póde traçar a trajetória profissional de vários médicos. Ver especificamente: "O cotidiano profissional e a historia em vidas de trabalho", p.41-130. 
Tabela 1.1 - Médicos com 'linhagem médica' distribuídos por décadas* segundo grau de parentesco. Brasil - 1995**

\begin{tabular}{lccccc}
\hline \multirow{2}{*}{$\begin{array}{c}\text { Grau de } \\
\text { parentesco }\end{array}$} & Anos 40-50 & Anos 60 & Anos 70 & Anos 80 & Anos 90 \\
\cline { 2 - 6 } & \multicolumn{1}{c}{$(\%)$} & \multicolumn{1}{c}{$(\%)$} & \multicolumn{1}{c}{$(\%)$} & \multicolumn{1}{c}{$(\%)$} & \multicolumn{1}{c}{$(\%)$} \\
\hline Avós & 0,8 & 2,0 & 1,5 & 3,0 & 3,7 \\
Pais & 6,4 & 8,8 & 9,6 & 11,5 & 14,3 \\
Filhos & 39,3 & 16,1 & 0,2 & 0,0 & 0,0 \\
Irmãos & 11,5 & 21,0 & 33,2 & 31,7 & 23,4 \\
Tíos & 10,8 & 6,0 & 11,5 & 14,2 & 22,6 \\
Primos & 11,8 & 27,1 & 33,0 & 33,7 & 32,4 \\
Sobrinhos & 10,2 & 12,3 & 5,2 & 0,7 & 0,3 \\
Netos & 1,4 & 0,0 & 0,0 & 0,3 & 0,0 \\
Não declararam & 7,7 & 6,9 & 5,9 & 4,9 & 3,4 \\
\hline TOTAL & 100,0 & 100,0 & 100,0 & 100,0 & 100,0 \\
\hline
\end{tabular}

* As décadas consideradas na tabela seguem a tipologia criada no Quadro 1.2, que associa a geração dos. médicos formados com a respectiva faixa etária.

** Cada médico podia citar até três parentes médicos.

Fonte: Pesquisa "Perfil dos Médicos no Brasil", Fiocruz/CFM.

Outro ponto relevante na nova configuração da origem social do médico no Brasil refere-se à ocupação profissional dos pais. Nestas últimas décadas, ocorreram mudanças importantes - como aumento do nível de escolaridade e emancipação feminina -, que nos permitem fazer algumas incursōes analíticas sobre seus efeitos no mundo médico. Se, no passado, como Starr (1991) sugere, para transformar-se em médico era preciso ter lastro social - estar ligado à terra dos grandes proprietários ou à aristocracia -, hoje predomina uma nova realidade social, mais urbana, menos patrimonialista, mas que mantém a característica de uma certa 'elitização' da origem médica.

Os dados da pesquisa mostram, por exemplo, que os médicos dos anos 90 são, em sua maioria, filhos (linhagem paterna) de médicos, juristas, professores universitários, profissionais liberais, comerciantes bem-sucedidos, empresários, políticos, intelectuais - enfim, filhos de uma seleta camada social bem posicionada na estrutura social. Mesmo conscientes das limitações dos dados sobre este tema disponiveis na pesquisa, podemos afirmar que a ocupação tanto paterna como materna sofreu alteraçóes significativas, voltando-se para atividades urbanas. No caso da ocupação materna, as alterações sociais visíveis nos permitem afirmar que as mães dos jovens médicos deixaram de ser 'donas-de-casa' e adquiriram status no mundo do trabalho. $O$ aumento da escolarização, o movimento feminista e um desenvolvimento social mais amplo contribuíram fortemente para alterar este quadro de modo efetivo. 
Gráfico 1.1 - Médicos distribuídos por décadas segundo profissão do pai.* Brasil - 1995

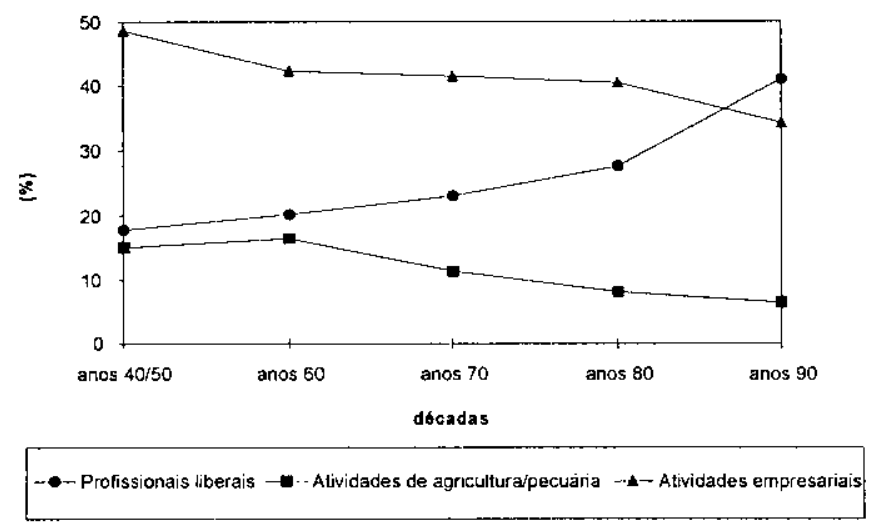

* Somente dentre aqueles que declararam a profissāo do pai.

Fonte: Pesquisa "Perfil dos Médicos no Brasil", Fiocruz/CFM.

Dentre aqueles que declararam a profissăo paterna, um em cada quatro médicos tem pai com escolaridade universitária. Esta proporção aumenta à medida que analisamos os médicos dos anos 80 e 90; ou seja, dos médicos da geração dos anos 90 , mais de $40 \%$ possuem pais nesta condição. O Gráfico 1.1 mostra uma clara evolução dos pais que exercem sua atividade como profissionais liberais e indica o decréscimo dos que desenvolvem atividade no setor agrícola.

\section{Gráfico 1.2 - Médicos distribuídos por décadas segundo profissão da mãe.*} Brasil - 1995

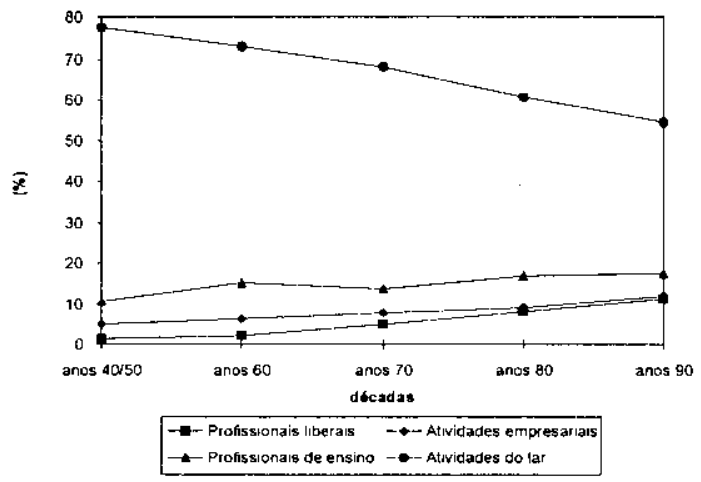

* Somente dentre aqueles que declararam a profissão da mãe.

Fonte: Pesquisa "Perfil dos Médicos no Brasil", Fiocruz/CFM. 
Quanto à ocupação materna, 65\% dos entrevistados afirmaram que a mãe é 'dona-de-casa', $15 \%$ atuam como professoras e somente $6 \%$ são profissionais de nível superior (seja na área da saúde ou em outras áreas). A seguir, vêm as que trabalham em atividades comerciais e como prestadoras de sevviços, que representam menos de $5 \%$. O Gráfico 1.2 mostra essa alteração da estrutura ocupacional materna.

Merece destaque o fato de que os dados apontam essa alteração, ou seja, enquanto as mães 'donas-de-casa' diminuíram significativamente sua atuação, as 'profissionais liberais' e as que se dedicam às 'atividades empresariais' experimentaram um incremento de sua participação (Gráfico 1.2).

\section{Medicina: uma profissāo tipicamente urbana?}

Vinculados cada vez mais a uma estrutura social com predominância urbana, naturalmente os médicos passaram a ter comportamentos e aspirações compatíveis com essa realidade social. Estudos realizados na década de 80 por Sayeg já demonstravam que a origem dos estudantes se mostrava preponderantemente urbana. Afirma o autor:

por mais democrático que seja o ensino, a maioria dos estudantes provém da
classe média ou da classe média superior. São estudantes que muitas vezes
foram submetidos a testes vocacionais e receberam preparação para os exames
vestibulares. Além destes, outros fatores fisicos e sociais influem significati-
vamente sobre a escolha da carreira na área biomédica. Entre nós, por exemplo,
o sexo ainda condiciona que seja feminina a maioria dos estudantes de enfer-
magem. (Sayeg:1987:72)

Uma década depois, a pesquisa confirma essa vocação urbana da medicina no Brasil: quase $80 \%$ do contigente médico exerce suas atividades em apenas sete estados - Rio de Janeiro, São Paulo, Minas Gerais, Bahia, Pernambuco, Paraná e Rio Grande do Sul - dos 27 da Federação (Tabela 1.2). Nesses estados, concentra-se a produçăo econômica do País, ou seja, grande parte do PIB brasileiro, bem como a maior parte da rede educacional (escolas e universidades). Conseqüentemente, neles vive a maior parte da população com maior nível de escolaridade. Essa política urbana equivocada, que concentra em poucos municípios, geralmente nas capitais, a urbanização e a industrialização, tem reunido, nesses centros urbanos, uma 'superpopulação' de profissionais qualificados (engenheiros, advogados, arquitetos, economistas, odontólogos, enfermeiros e, evidentemente, médicos). A pesquisa constata tanto a elevada concentração de médicos (no Rio de Janeiro e em São Paulo), como a sua escassez ou até ausência em diversos municípios do Pará, Amazonas, Ceará e Pernambuco. 
Tabela 1.2 - Médicos segundo Unidades da Federação. Brasil - 1995

\begin{tabular}{|c|c|c|c|}
\hline \multirow{2}{*}{ Unidades da Federação } & \multicolumn{2}{|c|}{ № de médicos no estado* } & \multirow{2}{*}{ Capita } \\
\hline & v. abs. & (\%) & \\
\hline Acre & 203 & 0,1 & 77,8 \\
\hline Amazonas & 1.369 & 0,7 & 94,1 \\
\hline Amapá & 208 & 0,1 & 94,2 \\
\hline Pará & 3.444 & 1,7 & 82,5 \\
\hline Rondônia & 492 & 0,2 & 50,8 \\
\hline Roraima & 144 & 0,1 & 95,8 \\
\hline Tocantins & 484 & 0,2 & 12,8 \\
\hline RECIĀO NORTE & 6.344 & 3,2 & 77,7 \\
\hline Alagoas & 2.639 & 1,3 & 88,3 \\
\hline Bahia & 8.730 & 4,4 & 69,6 \\
\hline Ceará & 4.537 & 2,3 & 82,1 \\
\hline Maranhão & 1.885 & 1,0 & 67,9 \\
\hline Paraíba & 3.000 & 1,5 & 65,7 \\
\hline Pernambuco & 7.366 & 3,7 & 77,1 \\
\hline Piauí & 1.410 & 0,7 & 74,6 \\
\hline Rio Grande do Norte & 2.253 & 1,1 & 78,4 \\
\hline Sergipe & 1.297 & 0,7 & 92,1 \\
\hline REGIĀO NORDESTE & 33.117 & 16,8 & 75,7 \\
\hline Espírito Santo & 3.250 & $\overline{1,6}$ & 58,0 \\
\hline Minas Gerais & 19.249 & 9,7 & 46,4 \\
\hline Rio de Janeiro & 36.802 & 18,6 & 74,0 \\
\hline São Paulo & 58.160 & 29,4 & 51,7 \\
\hline RECIĀO SUDESTE & 117.461 & 59,5 & 58,0 \\
\hline $\begin{array}{l}\text { Paraná } \\
\end{array}$ & 8.889 & 4,5 & 50,7 \\
\hline Rio Grande do Sul & 14.808 & 7,5 & 51,5 \\
\hline Santa Catarina & 4.494 & 2,3 & 30,8 \\
\hline REGIÄO SUL & 28.191 & 14,3 & 47,9 \\
\hline Distrito Federal & 4.759 & 2,4 & 100,0 \\
\hline Goiás & 4.373 & 2,2 & 64,3 \\
\hline Mato Grosso do Sul & 1.815 & 0,9 & 60,7 \\
\hline Mato Grosso & 1.497 & 0,8 & 54,1 \\
\hline REGIÃO CENTRO-OESTE & 12.444 & 6,3 & 76,2 \\
\hline BRASIL & 197.557 & 100,0 & 61,3 \\
\hline
\end{tabular}

* Refere-se ao total geral de médicos ativos, cadastrados no Conselho Federal de Medicina, estando incluídos todos os municípios năo pesquisados que compõem o interior do País.

Fonte: Cadastro Nacional dos Médicos, CFM - 1995. 
Os dados da pesquisa sugerem que os médicos tendem a residir nas capitais do País $(61,3 \%$ do total), tendência verificada com mais ênfase nas regiōes Norte, Nordeste e Centro-Oeste (Tabela 1.2). A concentração nas capitais é mais acentuada nas regiões Norte e Nordeste, nas quais os médicos respondem, respectivamente, por $77,7 \%$ e $75,7 \%$ do total de profissionais. No Centro-Oeste, de cada quatro médicos, um vive em municípios do interior. Na região Sudeste, essa relação se mostra mais homogênea, representando dois de cada cinco médicos, ou seja, cerca de $40 \%$. Na região Sul, observa-se um equilíbrio entre a distribuição populacional: $47,9 \%$ dos profissionais estão nas cidades de Curitiba, Florianópolis e Porto Alegre; $52,1 \%$ moram no interior dos estados. A pesquisa mostra que a regiāo Sudeste responde por $59,5 \%$ do total de médicos do País, seguida pelas regiōes Nordeste $(16,8 \%)$, Sul $(14,3 \%)$, Centro-Oeste $(6,3 \%)$ e Norte $(3,2 \%)$.

Uma vez que a economia está concentrada nos grandes centros (capitais e municípios de grande porte), ocorre um desequilíbrio entre as necessidades da população por assistência médica e os interesses e necessidades individuais dos médicos. Médici (1987:91) analisa este fenômeno na década de 1980 e mostra que

um dos aspectos mais debatidos nas politicas de recursos humanos em saúde no Brasil refere-se à alta concentraçăo de médicos nas regiōes mais desenvolvidas e, conseqüentemente, à insuficiência destes profissionais nas regiōes mais carentes do país.

Para esse autor,

certamente o principal fator que vem impedindo uma distribuição mais eqüitativa dos médicos no território nacional é a concentração regional de renda nacional. Grande parte dos senviços de saúde no Brasil repousa no assalariamento, no trabalhador que contribui para a previdência social ou na população que detém poder de compra para pagar o trabalho do médico ou remunerar os serviços de saúde. Desta forma, é natural que o mercado de trabalho médico venha a se concentrar nas regiões onde as condiçōes descritas sejam predominantes. Por isso, $98,6 \%$ dos médicos residiam nas regiōes urbanas brasileiras em 1980, dado que estas caracterizam-se cada vez mais pelos laços de assalariamento e pela mercantilização e monetarização das relações de troca da economia. (p.92)

$O$ indicador médicos/1.000 habitantes demonstrado nas Tabelas 1.3 e 1.4 sugere a existência de uma heterogeneidade na distribuição de médicos em todos os estados do Brasil, com destaque para as regióes Sudeste e Sul. Nas capitais dessas regiões, os números atingem níveis de países desenvolvidos, ao passo que em vários municípios brasileiros, inclusive nessas regiōes mais ricas, as estimativas observadas retratam níveis de países subdesenvolvidos. Apesar de observarmos uma pequena redução da concentração de profissionais nas capitais em comparação aos dados do IBGE referentes às décadas de 70 e 80 e os dados da pesquisa, isso não significa nenhuma mudança efetiva na distribuição dos médicos em todo o território nacional. 
Tabela 1.3 - Relação médico/1.000 habitantes segundo grandes regiōes. Brasil - 1970/1980/1995

\begin{tabular}{lcccc}
\hline $\begin{array}{l}\text { Regiōes/Unidades da } \\
\text { Federação }\end{array}$ & 1970 & 1980 & 1995 & \begin{tabular}{c} 
Incremento \\
relativo \\
\cline { 2 - 4 }$(70 / 95)(\%)$
\end{tabular} \\
\cline { 2 - 5 } Regiāo Norte & 0,09 & 0,44 & 0,52 & 477,8 \\
Regiāo Nordeste & 0,28 & 0,56 & 0,66 & 135,7 \\
Regiāo Sudeste & 0,72 & 1,08 & 1,64 & 127,8 \\
$\quad$ Rio de Janeiro & 1,15 & 2,10 & 2,05 & 78,3 \\
$\quad$ São Paulo & 0,79 & 0,86 & 1,75 & 121,5 \\
Região Sul & 0,43 & 0,98 & 1,23 & 186,0 \\
Região Centro-Oeste & 0,22 & 0,66 & 1,23 & 459,1 \\
\hline BRASIL & 0,48 & 0,85 & 1,19 & 147,9 \\
\hline
\end{tabular}

Fonte: IBCE: Censos demográficos de 1970 e 1980. In: Machado et al.(1992). Os dados para 1995 referem-se à "Pesquisa Perfil dos Médicos no Brasit", Fiocruz/CFM.

Estudiosos sobre o tema (Médici, Sayeg, Nogueira, Girardi, Paim, Machado, entre outros) vêm analisando esta questão desde a década de 70 e, em publicação do início desta década, mostram que:

apesar dos esforços do governo federal, do Ministério da Saúde e das secretarias estaduais em aparelharem a rede pública de saúde dos estados nordestinos, o baixo poder aquisitivo da população tem impedido uma maior fixaçāo de médi$\cos$ na regiāo. Como salientou Celso Furtado, em artigo publicado no caderno especial do $/ 8$ de 20/11/83, 'se é verdade que o Produto Bruto do Nordeste quadruplicou entre 1960 e 1980, dois terços da população trabalhadora permanecem com uma renda igual ou inferior a um salário mínimo'. Portanto, na atual estrutura privatizante da atenção médica no Brasil, somente uma melhoria substancial da distribuição dos rendimentos da população mais carente poderá alterar a situação vigente. (Machado et al. 1992:66)

\section{Concluem os autores:}

Fica claro que as desigualdades sócio-econômicas sāo os principais fatores impeditivos de uma adequada distribuição de profissionais de saúde e médicos, em nível do território nacional. Tais desigualdades se expressam näo somente na baixa taxa de investimento público nas regiões mais carentes, mas também na má qualidade de vida de suas populaçōes. Este estado de coisas năo propicia, de uma forma ou de outra, a existência de condiçōes totalmente adequadas para o exercício da medicina. (p.67) 
Tabela 1.4 - Relação médicos/1.000 habitantes segundo Unidades da Federação. Brasil - 1995

\begin{tabular}{|c|c|c|c|c|c|c|}
\hline \multirow{2}{*}{$\begin{array}{l}\text { Unidades da } \\
\text { Federação }\end{array}$} & \multicolumn{3}{|c|}{ População de médicos } & \multicolumn{3}{|c|}{ Médicos/1.000 habitantes } \\
\hline & capital & interior* & TOTAL & capital & interior & TOTAL. \\
\hline Acre & 158 & 45 & 203 & 0,78 & 0,18 & 0,45 \\
\hline Amazonas & 1.336 & - & 1.336 & 1,21 & - & 0,59 \\
\hline Amapá & 195 & 12 & 207 & 1,06 & 0,09 & 0,65 \\
\hline Pará & 2.822 & - & 2.822 & 2,46 & - & 0,53 \\
\hline Rondônia & 246 & 256 & 502 & 0,80 & 0,26 & 0,39 \\
\hline Roraima & 138 & 6 & 144 & 0,83 & 0,07 & 0,57 \\
\hline Tocantins & 62 & 422 & 484 & 1,11 & 0,45 & 0,49 \\
\hline REGIÄO NORTE & 4.957 & 741 & 5.698 & 1,56 & 0,10 & 0,52 \\
\hline Alagoas & 2.283 & - & 2.283 & 3,33 & - & 0,86 \\
\hline Bahia & 6.048 & 2.677 & 8.725 & 2,73 & 0,26 & 0,70 \\
\hline Ceará & 3.691 & - & 3.691 & 1,96 & - & 0,56 \\
\hline Maranhão & 1.288 & 614 & 1.902 & 1,70 & 0,14 & 0,37 \\
\hline Paraíba & 1.934 & 1.034 & 2.968 & 3,59 & 0,37 & 0,90 \\
\hline Pernambuco & 5.727 & - & 5.727 & 4,33 & - & 0,78 \\
\hline Piauí & 1.052 & - & 1.052 & 1,61 & - & 0,39 \\
\hline Rio Grande do Norte & 1.707 & - & 1.707 & 2,61 & - & 0,67 \\
\hline Sergipe & 1.194 & - & 1.194 & 2,78 & - & 0,76 \\
\hline REGIĀO NORDESTE & 24.924 & 4.325 & 29.249 & 2,73 & 0,12 & 0,66 \\
\hline Espírito Santo & 1.870 & 1.621 & 3.491 & 6,89 & 0,66 & 1,27 \\
\hline Minas Gerais & 8.978 & 9.979 & 18.957 & 4,32 & 0,70 & 1,16 \\
\hline Rio de Janeiro & 27.013 & - & 27.013 & 4,84 & - & 2,05 \\
\hline São Paulo & 29.985 & 28.119 & 58.104 & 3,02 & 1,21 & 1,75 \\
\hline REGIÄO SUDESTE & 67.846 & 39.719 & 107.565 & 3,80 & 0,83 & 1,64 \\
\hline Paraná & 4.458 & 4.366 & 8.824 & 3,21 & 0,60 & 1,02 \\
\hline Rio Grande do Sul & 7.619 & 7.181 & 14.800 & 5,89 & 0,88 & 1,56 \\
\hline Santa Catarina & 1.397 & 3.087 & 4.484 & 5,13 & 0,69 & 0,94 \\
\hline REGIÄO SUL & 13.474 & 14.634 & 28.108 & 4,56 & 0,73 & 1,23 \\
\hline Distrito Federal & 4.784 & . & 4.784 & 2,80 & - & 2,80 \\
\hline Goiás & 2.787 & 1.564 & 4.351 & 2,86 & 0,48 & 1,03 \\
\hline Mato Grosso do Sul & 1.103 & 735 & 1.838 & 1,89 & 0,57 & 0,98 \\
\hline Mato Grosso & 787 & 672 & 1.459 & 1,75 & 0,37 & 0,65 \\
\hline REGIÄO CENTRO-OESTE & 9.461 & 2.971 & 12.432 & 2,55 & 0,47 & 1,23 \\
\hline BRASIL & 120.662 & 62.390 & 183.052 & 3,28 & 0,53 & 1,19 \\
\hline
\end{tabular}

* O interior dos estados cujo contingente médico é inferior a 30\% nāo foi pesquisado.

Fonte: Pesquisa "Perfil dos Médicos no Brasil", Fiocruz/CFM. 


\section{Os médicos no contexto regional}

Na formação do Brasil e em sua ocupação geográfica, o Nordeste teve um papel singular. Diferentemente do que ocorreu em outras regiões, a populaçāo nordestina, em especial aquela com baixa qualificaçăo profissional, migrou muito à procura de melhores condiçōes de vida e trabalho. Essa situação não se alterou ao longo do tempo, pois, ainda hoje, os nordestinos fazem esse movimento migratório em direçāo às regiões mais desenvolvidas do País.

Sem ter a pretensāo de traçar o perfil migratório dos médicos no Brasil, a análise dos dados referentes à origem desses profissionais aponta, contudo, algumas situações interessantes (Figura 1.1). Com certeza, não será este trabalho que responderá a estas instigantes questōes, mas, seguramente, apontará para temas e problemáticas extremamente importantes para traçar políticas de recursos humanos com base em especificidades regionais. $O$ mercado de trabalho regional, por exemplo, apresenta comportamentos que mostram, por um lado, mercados mais fechados (Nordeste e Sul) ou mais consolidados (Sudeste) e, por outro, mercados em formação (Norte e Centro-Oeste).

A Tabela 1.5 esclarece um pouco melhor esse movimento migratório dos médicos brasileiros, sugerindo uma certa tendência à formaçăo de mercados com características próprias.

Minas Gerais se destaca como um 'estado migrador', seguido de Rio de Janeiro e São Paulo, fato explicado em parte pela alta concentração de escolas médicas nesses estados. Apenas um estado nordestino - Pernambuco - figura entre os estados de maior volume migratório, mesmo assim localizado apenas no movimento de migração PernambucoRoraima. Paradoxalmente, a totalidade dos estados que compõem a regiāo Nordeste apresenta as menores taxas de migração de todo o País, o que sugere um mercado fechado e tipicamente nordestino, onde as trocas de serviços e profissionais especializados são realizadas no interior da própria regiāo. As taxas de médicos migrantes nesses estados nordestinos são baixas em relaçăo às de outros estados (Alagoas - 17,9\%; Ceará - 17,5\%; Bahia $20,1 \%$ etc.). Rio Grande do Sul e Minas Gerais destacam-se como os estados brasileiros que possuem a menor participação de médicos migrantes - apenas 5,7\% e 13,1\%, respectivamente - e as menores taxas de imigração - 1,8\% e 0,9\% (embora o Rio Grande do Sul seja um estado-fronteira e Minas Gerais figure como estado migrador) -, o que sugere a existência de mercados fechados, constituídos de médicos da própria terra. Nem os estados vizinhos ao Rio Grande do Sul (Santa Catarina e Paraná), nem os vizinhos a Minas Gerais (Rio de Janeiro, São Paulo e Espírito Santo) acompanham o comportamento de seus estados limítrofes. Dada a particularidade do Distrito Federal, este se destaca como tendo um mercado de trabalho constituído por médicos migrantes em sua quase totalidade (96,2\%), seguido de Tocantins, Rondônia, Roraima e Mato Grosso. Por último, os estados do Norte, quase todos de urbanização recente (Acre, Amapá, Rondônia, Roraima e Tocantins), destacam-se como estados nos quais o movimento migratório é intenso, constituindo mercados em pleno processo de formação. 
FIGURA 1.1 - Origem dos médicos. Brasil - 1995

RESIDENTES NA REGIÃO NORTE

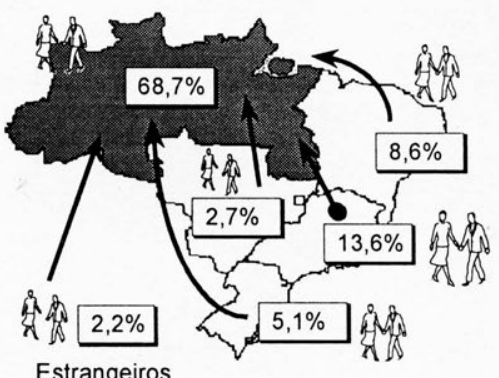

Estrangeiros

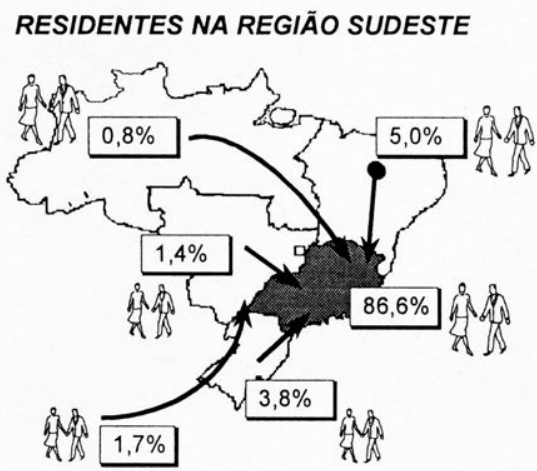

Estrangeiros
RESIDENTES NA REGIÃO NORDESTE

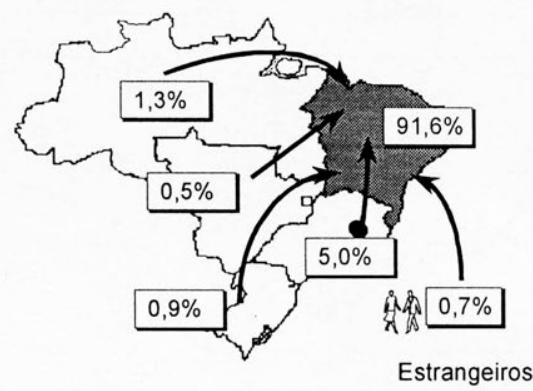

RESIDENTES NA REGIÃO SUL

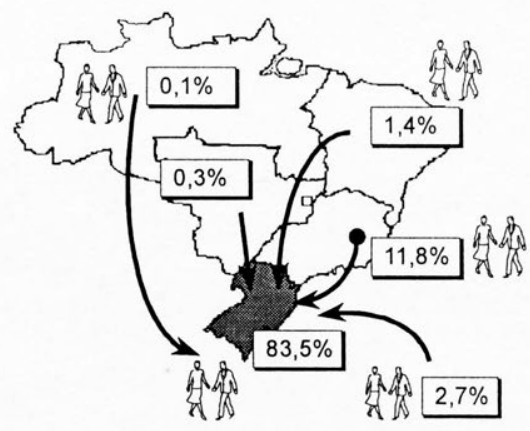

Estrangeiros

\section{RESIDENTES NA REGIÃO CENTRO-OESTE}

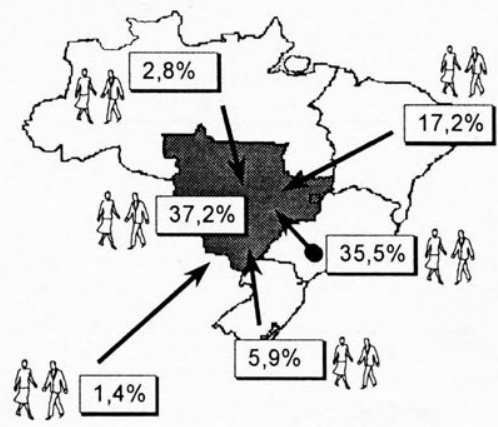

Estrangeiros

Nota: A diferença observada com relação ao total $100 \%$ em cada mapa refere-se àqueles que não declararam sua naturalidade.

Fonte: Pesquisa "Perfil dos Médicos no Brasil, Fiocruz/CFM. 
Tabela 1.5 - Origem dos médicos segundo Unidades da Federação** Brasil - 1995

\begin{tabular}{|c|c|c|c|c|}
\hline \multirow{2}{*}{$\begin{array}{l}\text { Unidades da } \\
\text { Federação }\end{array}$} & $\begin{array}{l}\text { № de médicos } \\
\text { no estado }\end{array}$ & $\begin{array}{c}\text { Naturais do } \\
\text { próprio estado }\end{array}$ & Migrantes** & Imigrantes \\
\hline & v. abs. & (\%) & $(\%)$ & (\%) \\
\hline Acre & 203 & 26,6 & 64,0 & 9,4 \\
\hline Amazonas & 1.336 & 52,7 & 45,5 & 1,8 \\
\hline Amapá (1) & 207 & 25,1 & 72,5 & 2,4 \\
\hline Pará & 2.822 & 86,7 & 11,4 & 1,8 \\
\hline Rondônia (2) & 502 & 10,8 & 86,5 & 2,8 \\
\hline Roraima (3) & 144 & 16,7 & 81,2 & 2,1 \\
\hline Tocantins (4) & 484 & 3,3 & 94,8 & 1,9 \\
\hline REGIĀO NORTE & 5.698 & 58,8 & 39,0 & 2,2 \\
\hline Alagoas & 2.283 & 82,1 & 17,9 & 0,0 \\
\hline Bahia & 8.725 & 79,6 & 20,1 & 0,4 \\
\hline Ceará & 3.691 & 82,5 & 17,5 & 0,0 \\
\hline Maranhão & 1.902 & 73,5 & 25,8 & 0,6 \\
\hline Paraíba & 2.968 & 85,4 & 14,1 & 0,5 \\
\hline Pernambuco & 5.727 & 72,3 & 26,0 & 1,7 \\
\hline Piauí & 1.052 & 78,4 & 21,0 & 0,6 \\
\hline Rio Grande do Norte & 1.707 & 70,7 & 28,2 & 1,1 \\
\hline Sergipe & 1.194 & 71,1 & 26,5 & 0,8 \\
\hline REGIĀO NORDESTE & 29.249 & 78,0 & 21,3 & 0,7 \\
\hline Espírito Santo & 3.491 & 68,1 & 30,4 & 1,5 \\
\hline Minas Gerais & 18.957 & 86,0 & 13,1 & 0,9 \\
\hline Rio de Janeiro & 27.013 & 62,4 & 34,9 & 1,5 \\
\hline Săo Paulo & 58.104 & 78,9 & 18,3 & 2,1 \\
\hline REGIÄO SUDESTE & 107.565 & 75,7 & 21,9 & 1,7 \\
\hline Paraná & 8.824 & 57,9 & 38,8 & 3,3 \\
\hline Rio Grande do Sul & 14.800 & 92,0 & 5,7 & 1,8 \\
\hline Santa Catarina (5) & 4.484 & 46,7 & 49,0 & 4,3 \\
\hline REGIÃO SUL & 28.108 & 74,0 & 23,0 & 2,7 \\
\hline Distrito Federal (6) & 4.784 & 3,8 & 96,2 & 1,0 \\
\hline Goiás (7) & 4.351 & 57,8 & 40,7 & 1,5 \\
\hline Mato Grosso do Sul (8) & 1.838 & 36,5 & 61,0 & 2,6 \\
\hline Mato Grosso (9) & 1.459 & 26,0 & 72,8 & 1,1 \\
\hline REGIĀO CENTRO-OESTE & 12.432 & 30,1 & 68,8 & 1,4 \\
\hline BRASIL. & 183.052 & 72,2 & 24,9 & 1,7 \\
\hline
\end{tabular}

* Inclui a migração entre estados da mesma regiảo. A diferença observada, com relação ao total de $100 \%$ em cada Unidade da Federação, refere-se àqueles médicos que nāo declararam sua naturalidade.

** Natural de outra Unidade da Federaçāo.

Nota: Os números de (1) a (9) correspondem aos estados que contribuíram com a maior migração da referida Unidade da Federação. (1) PA e RJ; (2) PR e MG; (3) MG, Rj e PE; (4) CO, MG e SP; (5) RS, RJ e RR; (6) MG, R) e GO; (7) SP, SC e RS; (8) SP, PR, MG e (9) SP, MG e PR.

Fonte: Pesquisa "Perfil dos Médicos no Brasil", Fiocruz/CFM. 


\section{A medicina feita por jovens}

O crescente incremento de novas escolas, que, conseqüentemente, aumenta o número de jovens médicos no mercado de trabalho, fornece um elemento novo na caracterização da profissão: o 'rejuvenescimento do contingente médico'. A pesquisa reafirma esse fenômeno: $70 \%$ dos médicos têm menos de 45 anos de idade.

Para facilitar nossa análise e buscar construir 'tipologias geracionais', em diversos momentos deste livro adotaremos essa tipologia, conforme o Quadro 1.2.

\section{Quadro 1.2 - Tipologia considerada para análise dos dados segundo décadas de formatura. Brasil - 1940-1990}

\begin{tabular}{|l|c|}
\hline $\begin{array}{c}\text { Médicos segundo } \\
\text { grupo etário }\end{array}$ & Geraçäo* \\
\hline 70 anos e mais & 40 \\
\hline $60-69$ anos & 50 \\
\hline $50-59$ anos & 60 \\
\hline $40-49$ anos & 70 \\
\hline $30-39$ anos & 80 \\
\hline menos de 30 anos & 90 \\
\hline
\end{tabular}

* Década em que se formou.

Fruto de uma transição demográfica, a profissão médica no Brasil apresentase hoje como um contingente de profissionais ativos, com características peculiares. Afirma Machado (1996:147),

até os anos de 1950, havia apenas 26 escolas de medicina, que formavam anualmente menos de 1.500 médicos. Na década de 1980, o Brasil passava a contar com 76 escolas médicas, as quais formavam em torno de 7.500 a oito mil novos médicos. No período de 1955 a 1990, o Brasil graduou 156.212 profissionais, o que eqüivale a mais de dois terços de todo o contingente médico existente hoje no mercado de trabalho.

Dessa forma, a concentração desordenada dos médicos nos grandes centros e o despovoamento de regiōes (Norte e Centro-Oeste, particularmente) refletem a política de expansão de médicos ocorrida nos anos 60 e 70 , provocando a concorrência e a disputa por clientela urbana.

Tal fenômeno vai ocorrer basicamente em decorrência do boom de novos médicos ocasionado com a abertura de escolas de medicina no final da década de 60 e no início da seguinte. 
Embora a tendência ao rejuvenescimento da força de trabalho em saúde seja geral, ela é absolutamente hegemônica no seio dos profissionais de nivel superior, basicamente em funçāo da reforma universitária e da explosão de egressos das escolas de $3^{30}$ grau. (Machado, 1992:54)

Com base nos dados da pesquisa, podemos afirmar que a medicina no Brasil é exercida hoje majoritariamente por profissionais jovens, com menos de 45 anos, considerando-se que os médicos ingressam no mercado de trabalho entre 26 e 28 anos de idade (seis anos de graduação e, em média, dois anos de residência, feita pela maioria dos profissionais), conforme a Tabela $1.6 .^{9}$ Isso significa dizer que $65,8 \%$ dos médicos que atuam no mercado de serviços de saúde têm menos de 16 anos de formados, o que configura um mercado em constantes reacomodações de necessidades e especificidades em nível tanto nacional quanto regional, já que o fenômeno atinge todas as Unidades da Federação.

\section{Tabela 1.6 - Médicos distribuídos por grandes regióes segundo faixa etária. Brasil - 1995}

\begin{tabular}{|c|c|c|c|c|c|c|c|c|c|c|c|c|}
\hline \multirow{2}{*}{$\begin{array}{l}\text { Faixa } \\
\text { etária }\end{array}$} & \multicolumn{2}{|c|}{ BRASIL } & \multicolumn{2}{|c|}{ Norte } & \multicolumn{2}{|c|}{ Nordeste } & \multicolumn{2}{|c|}{ Sudeste } & \multicolumn{2}{|c|}{ Sul } & \multicolumn{2}{|c|}{ Centro-Oeste } \\
\hline & v. abs. & (\%) & abs. & $(\%)$ & v. abs. & $(\%)$ & v. abs. & $(\%)$ & v. abs. & $(\%)$ & v. abs. & $(\%)$ \\
\hline हरा & 506 & 6,3 & 200 & 5,0 & 1.665 & 5,7 & 6.716 & 6,2 & 7.946 & 6,9 & 896 & 7,2 \\
\hline 28 & 10.979 & 6,0 & 187 & 3,3 & 1.316 & 4,5 & 7.156 & 6,7 & 1.655 & 5,9 & 665 & 5,3 \\
\hline De 30 a 34 & 30.865 & 16,9 & 837 & 14,7 & 4.241 & 14,5 & 19.021 & 17,7 & 4.849 & 17,3 & 1.917 & 15,4 \\
\hline De 35 a 39 & 32.5 & 17,8 & 946 & 16,6 & 5 & 0 & 1 & 17.6 & 56 & 17,6 & 2.141 & 11 \\
\hline De 4 & 3 & 18,8 & 1.232 & 2 & 5 & 5 & 9 & 18,1 & 20 & 19,6 & 2.403 & 19,3 \\
\hline e & 25.77 & 14,1 & 1.151 & 20,2 & 4 & 16,6 & 2 & 12,8 & 4.067 & 14,5 & 1.977 & 15,9 \\
\hline De 50 a 59 & 21.260 & 11,6 & 684 & 12,0 & 3.935 & 13,5 & 11.379 & 10,6 & 3.585 & 12,8 & 1.677 & 13,5 \\
\hline De 60 a 69 & 10.408 & 5,7 & 291 & 5,1 & 1.517 & 5,2 & 6.856 & 6,4 & 1.142 & 4,1 & 602 & 4,8 \\
\hline an & 5.33 & 2,9 & 87 & 1,5 & 469 & 1,6 & 4.235 & 3,9 & 388 & 1,4 & 154 & 1,2 \\
\hline S & 183.052 & 100,0 & 5.698 & 100,0 & 29.249 & 100,0 & 107.565 & 100,0 & 28.108 & 100,0 & 12.432 & 100,0 \\
\hline
\end{tabular}

Fonte: Pesquisa "Perfil dos Médicos no Brasil", Fiocruz/CFM

Não podemos dizer, entretanto, que esse processo de rejuvenescimento acarretará alteraçōes na pirâmide etária verificada atualmente. Se hoje o Brasil conta com quase a metade de médicos com menos de 45 anos e pouco menos de $10 \%$ com mais de 60 anos, isso nāo significa que esse contingente vai se manter estruturalmente jovem. Observamos que, nas décadas de 70 e 80 , ocorreu um certo 'dese-

9 Nota-se, por exemplo, que a idade média dos médicos pouco variou: de 43 anos para a regiăo Norte até 42 anos para o Nordeste, 43 anos para o Sudeste, 40 anos para o Sul e 42 anos para o Centro-Oeste. 
quilíbrio etário', fruto de uma espantosa produção de médicos a partir desse período. Tal fato sugere o crescimento da população de idosos, como começa a ocorrer com a pirâmide populacional brasileira, na qual se verifica o crescimento do segmento etário com mais de 60 anos.

\section{A feminilização: um processo em curso}

O fenômeno da crescente participação das mulheres no mundo do trabalho é fato observável em nível mundial, alterando definitivamente o quadro de trabalhadores em quase todos os setores da economia. A saúde acompanhou esse processo e tem experimentado uma das mais altas taxas de feminilização no mundo do trabalho. No Brasil, as escolas médicas refletem, no registro de novas matrículas, essa rápida ascensāo das mulheres na profissão.

Se até pouco tempo o ofício da medicina era uma prática de homens, esta situaçăo vem se alterando de modo progressivo e irreversível com a chegada das mutheres a um mundo até então hegemonicamente masculino. $O$ crescimento da participação das mulheres na atividade médica é fato notório em vários segmentos da economia. A saúde assume lugar de destaque nesse processo de feminilização. Na década de 70 , por exemplo, nas atividades da saúde, as mulheres representavam $41,5 \%$, passando para $62,8 \%$ na década seguinte. No entanto, o incremento maior vai ocorrer com o contingente feminino universitário, que passa, no mesmo período, de $17,9 \%$ para $35,2 \%$. Machado (1993:258) mostra que

com exceção da Europa oriental - entre 1980 e 1985 registrou-se um incremento de quase sete pontos percentuais na participação das mulheres nas escolas de medicina do mundo. Em todos os continentes, em 1984-1985, as matrículas femininas representaram mais de $25 \%$ do total; chegaram a $54,1 \%$ na Europa oriental, 43,9\% na Europa ocidental, 38,9\% nas Américas e $36,8 \%$ na Oceania.

Essa é uma questāo importante, que afeta nuclearmente a profissão médica e que denominamos 'transição de gênero'. Arriscamos afirmar que, provavelmente, nas próximas décadas, a profissão médica passará a vigorar no cenário das profissões liberais como uma profissão predominantemente feminina. No Brasil, esse fenômeno de feminilização é marcante: na década de 70 , as mulheres representavam $11 \%$ na profissão médica, passando para $22 \%$ na década seguinte. Atualmente, como pode ser visto na Tabela 1.7 , registram-se $32,7 \%$ de profissionais de gênero feminino, sendo mais acentuada a participação feminina nas capitais brasileiras $(36,8 \%)$. Por outro lado, a análise dos dados regionais mostra um Nordeste com acentuada participação do contingente feminino $(41,1 \%)$ em oposição ao Sul $(26,9 \%)$.

Enfocando-se o segmento etário de médicos com até 45 anos de idade, o contingente feminino é ainda maior (41\%), o que reforça a idéia de que a feminilizaçăo é um fenômeno geracional de pós-década de 70 . No contingente com menos de 30 anos, a participaçăo feminina aumenta ainda mais, representando cerca de $50 \%$ deste segmento. 
A série temporal com os anos de formados dos médicos segundo o gênero (masculino e feminino) explicita esse fenômeno de feminilização e sugere que, dentro de pouco tempo, provavelmente nas próximas duas décadas, pode ser atingida a mesma proporção entre homens e mulheres em todas as faixas etárias, tanto nas capitais como nos municípios que compōem o interior do País (Gráficos 1.3 e 1.4).

Enfim, como vamos analisar adiante, no capítulo 5, especificamente sobre as médicas no Brasil, esse processo de feminilização ocorrido com a profissão médica tem provocado alterações importantes na estrutura e na composição do mercado dos serviços médicos em geral.

Tabela 1.7 - Médicos distribuídos por gênero segundo grandes regiões. Brasil - 1995

\begin{tabular}{l|r|r|r|r|r|r}
\hline \multirow{2}{*}{$\begin{array}{c}\text { Brasil e Grandes } \\
\text { Regiōes }\end{array}$} & \multicolumn{2}{c|}{ Masculino } & \multicolumn{2}{c|}{ Feminino } & \multicolumn{2}{c}{ TOTAL } \\
\cline { 2 - 7 } & \multicolumn{1}{c|}{ v. abs. } & $(\%)$ & v. abs. & $(\%)$ & v. abs. & \multicolumn{1}{c}{$(\%)$} \\
\hline Norte & 3.763 & 66,0 & 1.935 & 34,0 & 5.698 & 100,0 \\
Nordeste & 17.224 & 58,9 & 12.025 & 41,1 & 29.249 & 100,0 \\
Sudeste & 72.656 & 67,5 & 34.909 & 32,5 & 107.565 & 100,0 \\
Sul & 20.559 & 73,1 & 7.549 & 26,9 & 28.108 & 100,0 \\
Centro-Oeste & 8.951 & 72,0 & 3.481 & 28,0 & 12.432 & 100,0 \\
\hline BRASIL - TOTAL & 123.153 & 67,3 & 59.899 & 32,7 & 183.052 & 100,0 \\
\hline BRASIL - Capitais & 76.255 & 63,2 & 44.407 & 36,8 & 120.662 & 100,0 \\
\hline BRASIL - Interiores & 46.898 & 75,2 & 15.492 & 24,8 & 62.390 & 100,0 \\
\hline
\end{tabular}

Fonte: Pesquisa "Perfil dos Médicos no Brasil", Fiocruz/CFM.

Gráfico 1.3 - Médicos distribuídos por gênero segundo tempo de formado. Brasil (capitais) - 1995

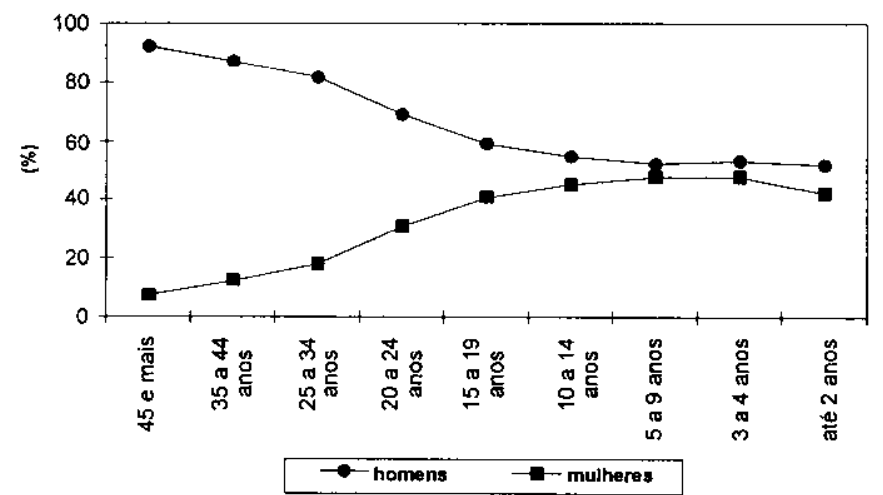

Fonte: Pesquisa "Perfil dos Médicos no Brasil", Fiocruz/CFM. 
Gráfico 1.4- Médicos distribuídos por gênero segundo tempo de formado. Brasil (interiores) - 1995

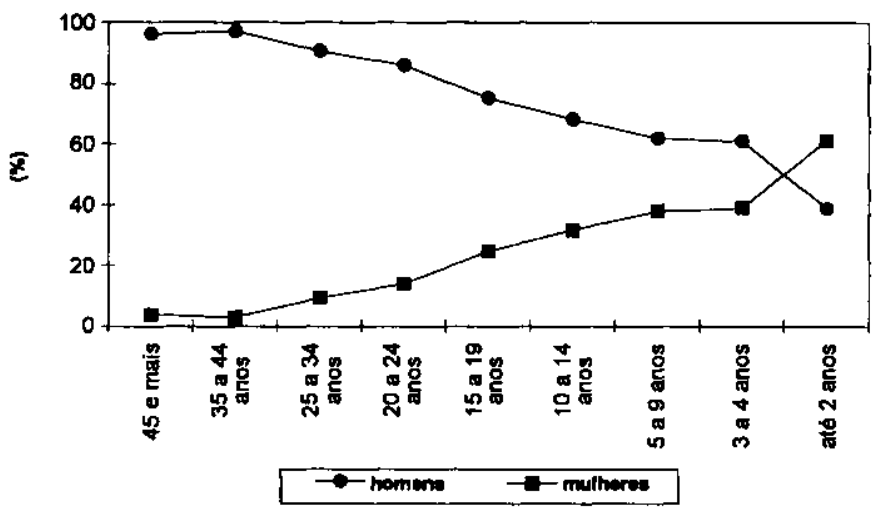

Fonte: Pesquisa "Perfil dos Médicos no Brasil", Fiocruz/CFM. 


\section{A FORMAÇĀO PROFISSIONAL}

\section{O CONTEXTO DA FORMAÇĀO MÉDICA NO BRASIL}

A história das instituiçōes e do próprio ensino médico no País é um elemento importante na compreensão da atual distribuiçăo desses profissionais. Assim, é importante lembrar que a primeira escola médica só foi criada em 1808, após a vinda da familia real portuguesa para o Brasil, pressionada pelo expansionismo francês. Até então, os poucos médicos aqui existentes haviam se formado em faculdades européias (especialmente em Portugal e na França) ou, no caso dos cirurgiōes barbeiros, credenciados após um questionável exame de proficiência. Afirma Araújo (1982:13):

a cirurgia ainda menosprezada, inclusive em nosso meio, era praticada por bisonhos e inexperientes cirurgiões mal preparados, porém legalmente habilitados à profissão, mercê de atestados que asseguravam haverem trabalhado durante quatro anos em clínicas hospitalares, complementados por 'atos de exames' superficialíssimos, por vezes verdadeiras palhaçadas perante delegados ou comissários da Real Junta do Protomedicato que the concedia a 'Carta de Aprovação' (...).

Desta forma, podemos dizer que a medicina no Brasil, até o século XVIII, era praticada por camadas sociais desprestigiadas e compunha-se do 'baixo clero', homens mal letrados, sem prestígio social e de pouca cultura. Poucos eram os que fugiam à regra. A prática da medicina constituía-se numa verdadeira anarquia de mercado. A empiria determinava a prática e esta não seguia as normas reguladoras. (Machado, 1996:127)

A tardia criação de faculdades nas colônias portuguesas, em comparação com as espanholas, é com frequêencia explicada por argumentos político-econômicos - o sistema colonial bloqueava o desenvolvimento do ensino superior no Brasil. Essa argumentação, entretanto, não deve ser exagerada, como explica Cunha (1986), uma vez que existem fatos que a contradizem. Se essa intenção de Portugal fosse assim 
tão forte, não teriam sido criados os cursos de filosofia, teologia e matemática nos colégios religiosos muito antes da chegada da família real portuguesa. Além da existência desses cursos, que não eram exclusivamente voltados para a formação de quadros profissionais para a Igreja, Cunha (1986:13) enfatiza ainda a acanhada dimensão do aparelho escolar de nível superior em Portugal, que, aliada ao relativamente reduzido contingente demográfico naquele país, seria outro fator capaz de minimizar a capacidade efetiva da metrópole em expandi-lo para as colônias.

Santos Neto (1993:30-31) mostra que

nos primeiros trezentos anos de Brasil, os físicos e cirurgiōes procediam do exterior. A coroa nomeava delegados do físico-mor e cingiāo-mor para atuarem na Colônia. Estes deveriam fiscalizar e fazer cumprir os regulamentos sanitários ditados pela Corte. Mais tarde, os 'filhos de posse' nascidos no Brasil passam a ter sua formaçăo na Europa, retornando em seguida para desenvolver seus oficios.

Assim, no início do século XIX, mais precisamente a partir de 1808 , expressa-se a necessidade premente de formar profissionais com o objetivo de ocupar postos na burocracia do Estado, já que, com a ocupação de Portugal pelas tropas de Napoleão, o staff estatal brasileiro deveria ser formado no próprio território. Foram criados cursos de direito, academias militares e de medicina, entre outros. As duas primeiras escolas médicas criadas, uma em Salvador e outra no Rio de Janeiro, estavam sediadas inicialmente em dependências militares. Apenas próximo à instalação da República, em 1898, é que outro curso viria a ser criado, dessa vez na capital do Rio Grande do Sul. Pouco a pouco, o número de escolas médicas no Brasil evoluiu, com destaque para o boom ocorrido no final da década de 60 e início de 70 (Gráfico 2.1).

Gráfico 2.1 - Escolas médicas segundo data de fundação. Brasil - 1808/1997

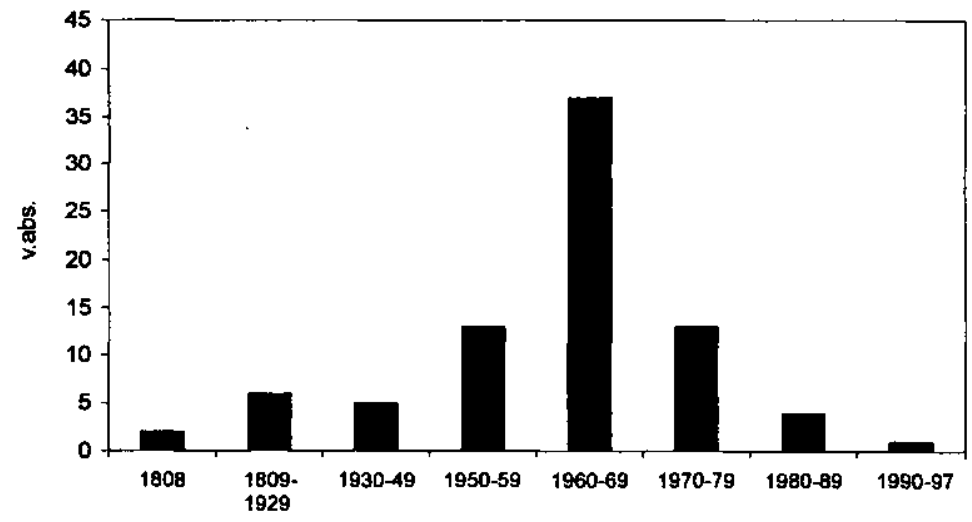

Fonte: MEC. 


\section{A FORMAÇĀO DOS MÉDICOS EM QUESTĀO}

Habilitadas pelo Conselho Federal de Educação, as 81 escolas médicas no Brasil ${ }^{1}$ são, em sua maioria, de natureza pública federal, com distribuição homogênea em todo o País, exceto nos estados em que (ainda) não existem escolas de medicina (Acre, Rondônia, Amapá e Tocantins) ${ }^{2}$ (Quadro 2.1). Tal fato mostra a política adotada pelo Estado brasileiro de prover e manter sob sua responsabilidade a formação de médicos em nosso País. Poucas são as escolas de natureza pública estadual ou municipal, a exemplo da Universidade de Săo Paulo e da Universidade do Estado do Rio de Janeiro. É sabido também que, por tradiçăo e cultura organizacional, nessas escolas públicas é que se encontram os melhores e mais bem equipados cursos de medicina do País.

Chama-nos a atençăo, no entanto, o fato de que, enquanto o setor público é hegemônico na formação médica do Norte, Nordeste e Centro-Oeste, o setor privado mostra sua importância nos estados das regiōes Sudeste e Sul, especialmente no interior desses estados. Das 38 escolas médicas privadas existentes no País, 28 (74\%) estão localizadas no interior.

A política concentradora de recursos econômicos e sociais no Sul e Sudeste provoca a enorme aglutinação das instituições de ensino médico, ou seja, $75 \%$ das escolas de medicina existentes no Brasil estão nessas duas regiōes. Além disso, das 81 escolas, 44 estão na Região Sudeste, sendo que 31 estão localizadas em Săo Paulo e no Rio de Janeiro (70\%).

Com base nos dados da pesquisa, observa-se que a metade $(51,8 \%)$ dos médicos graduados em faculdades públicas reside no Sudeste, $20,6 \%$ no Nordeste e $16,1 \%$ no Sul. Já os egressos das escolas privadas, coerentemente com a distribuição geográfica destas, concentram-se de forma maciça no Sudeste $(75,2 \%){ }^{3}$ Tal fato explica-se pela política do governo de equipar cada Unidade da Federação com pelo menos uma universidade pública federal, havendo em quase todas cursos de medicina, o que não ocorre com as universidades privadas, que, em sua maioria, estão concentradas no Sul-Sudeste.

Sob outra perspectiva, observa-se que, independentemente da natureza da instituição (pública ou privada), as que estão localizadas no interior têm contribuído para a maior fixação dos médicos fora da esfera urbana das capitais brasileiras. Comparem-se, por exemplo, os números aqui apresentados. Nas escolas de medicina com sede nas capitais, o quadro é o seguinte: dos 5.359 médicos formados na Fa-

1 No início da pesquisa, em 1994, nos arquivos da Associação Brasileira de Ensino Médiço, havia oitenta escolas médicas, sendo posteriormente aprovada a criação da Escola de Medicina do estado de Roraima.

2 Três escolas, por serem de criação recente, não tinham ainda nenhuma turma de graduados quando da pesquisa de campo, como, por exemplo, o curso de medicina da Universidade Federal de Roraima, que foi reconhecido pelo Ministério da Educação após o início da pesquisa.

3 Para mais dados sobre este assunto, ver MACHADO et al. (1996, v.1). 
culdade de Medicina da Universidade Federal da Bahia, 4.103 estão trabalhando nas capitais; o mesmo ocorre na Universidade do Rio de Janeiro - Uni-Rio - (dos 5.606 formados, 5.102 estão nas capitais); no Centro de Ciências da Saúde da Universidade Federal Alagoas (dos 1.474 formados, 1.446 se encontram nas capitais); na Universidade Federal do Amazonas (dos 1.500 médicos formados, 1.168 atuam nas capitais). Num outro movimento, a situação se inverte, ou seja, aqueles que fazem o curso em escolas de medicina do interior acabam fixando residência em algum ponto do interior do País, como mostram os seguintes dados: dos 2.300 profissionais formados pela Faculdade de Medicina de Ribeirāo Preto, 1.816 estão no interior; dos 1.851 médicos graduados na Universidade Federal em Pelotas, 1.435 vivem no interior; dos 1.653 formados pela Faculdade de Medicina de São José do Rio Preto, 1.586 encontram-se trabalhando no interior do País. Somente os profissionais formados nas escolas do estado do Rio de Janeiro apresentam comportamento peculiar; ou seja, os médicos formados nessas escolas, sejam elas localizadas na capital ou no interior, acabam fixando residência nas capitais, como pode ser visto no Quadro 2.1.

A política concentradora de equipamentos econômicos e sociais - que levou à criação das maiores escolas de medicina nas capitais do Brasil (quase sempre federais) - fomentou e solidificou a fixação dos médicos nos grandes centros. Os dados são contundentes. Veja-se, por exemplo, a proporção de médicos graduados em algumas universidades federais que se deslocaram para o interior: do Rio Janeiro (14\%); do Pará ( $8 \%)$; de Pernambuco (7\%); do Ceará (4\%); de Alagoas (2\%); do Rio Grande do Norte (4\%).

Mas como se deu a expansão dessas escolas médicas no Brasil? Até 1950, as 13 escolas médicas existentes no País eram exclusivamente de natureza pública. Com a criação, naquele ano, da Faculdade de Ciências Médicas de Pernambuco e do Centro de Ciências Médicas e Biológicas de Sorocaba, surgem as primeiras instituiçōes privadas de ensino médico no País. Nessa mesma década, ocorre um significativo crescimento, com o surgimento de 14 novas escolas, sendo cinco particulares. Na década de 60, 36 escolas são criadas, sendo a maioria de natureza privada. Segundo Maciel (1972), essa extraordinária expansão, ${ }^{4}$ mais acentuada a partir de 1965 , refletiu tanto a pressão das classes médias urbanas por aumento das vagas no sistema universitário, como também satisfez as expectativas dos planejadores, que buscavam atender às novas necessidades de desenvolvimento da assistência médica no País. ${ }^{5}$ Fruto imediato dessa nova política foi, no caso da medicina, a explosāo de novos profissionais e novos empregos médicos, ou seja, "entre 1977 e 1987, por exemplo, para os 80 mil novos médicos foram criados cerca de 100 mil empregos" (Machado, 1996:119). Mas essa expansāo não esteve, evidentemente, alienada da política mais ampla do governo de expandir o ensino universitário no País. Nessas

4 Para maiores informaçōes, consultar Brasil (1972).

5 Ver FrRrFira (1964). 
três últimas décadas, ocorreu um crescimento na cobertura universitária maior do que em qualquer outro nível de ensino. Afirma Tedesco (1995:108):

hoje a qualidade de estudante universitário é compartilhada por centenas de milhares de jovens. No Brasil, por exemplo, a matricula universitária passou de 100 mil, em 1960, a mais de um milhăo em 1975. Na Venezuela, de 25 mil a mais de 200 mil. No México, de 66 mil a mais de 500 mil. Na Argentina, de $250 \mathrm{mil}$ a $600 \mathrm{mil}$.

Amparados por essa posição das autoridades educacionais durante o regime militar e pela falta de uma política que estabelecesse uma estratégia disciplinadora do processo, os empresários da educação abriram cursos sem uma devida fiscalização (Brasil, 1972:15 e 28-39). Muitos desses cursos não apresentavam condiçōes mínimas, fosse pela falta de infra-estrutura de apoio (laboratórios e bibliotecas), fosse pela falta de docentes qualificados e campo de prática apropriado. Na opinião de Rego (1994:48),

é muito comum, ao analisar a 'crise do ensino médico', atribuir sua responsabilidade à criaçăo de grande quantidade de novas escolas médicas, especialmente durante a década de 60 e início da de 70 . Por exemplo, Moraes analisando tal crescimento, afirma que 'não houve planejamento adequado para que se preparasse o corpo docente para essas escolas e também nảo se exigiu, para permitir suas instalaçōes, o pré-requisito do Hospital Escola (...) Houve uma massificação na formação de médicos. A consequeência foi a queda do padrăo do ensino'. A fuga para os estágios extracurriculares também, da mesma forma, costuma ser considerada como uma conseqüência deste crescimento.

"No período de 1955 a 1990, o Brasil graduou 156.212 profissionais, o que equivale a mais de dois terços de todo o contingente médico existente hoje no mercado de trabalho" (Machado, 1996:147). Esse crescimento desordenado, sem um efetivo controle da corporação e com nefastas consequêencias do ponto de vista de oferta e demanda, ensejou um movimento corporativo oposto ao preconizado nos anos 50 e 60, que culminou com a proibição de criar novas escolas a partir de 1971 (Brasil, 1972:8). Essa proibição, revalidada sistematicamente, vigorou até 1989, quando, por meio de Decreto Presidencial (Brasil:1989), regulamentado por Portaria Interministerial (Brasil, 1990), foram estabelecidos critérios mediante os quais seriam apreciados os pedidos de autorização de funcionamento de novos cursos. Tais critérios, curiosamente, são muito semelhantes aos vigentes no início da década de 1960,6 embora tenham sido 'atualizados' para a nova conjuntura política e burocrática. Tal como no passado, esses critérios vêm se mostrando pouco eficazes para a efetiva regulação desse processo. Novas escolas têm sido criadas não só como resultado de bem articuladas injunções políticas (a despeito de pareceres técnicos contrários), como por meio do artifício de criar 'universidades' e, com amparo no preceito

6 Os critérios existentes naquele período foram desconsiderados por determinaçāo do entāo ministro da Educação, senador Tarso Dutra (MACIEL, 1972:35). 
constitucional da 'autonomia universitária', adquirir a prerrogativa de colocar em funcionamento qualquer curso superior.

Nesse contexto decorrente da expansăo desordenada, a corporação esboça críticas no sentido de 'conter' esse processo.

Se nos anos de 1960 as entidades médicas apoiaram a abertura de novas escolas, hoje a realidade é outra. Os inúmeros boletins, jornais, anais de congressos e encontros registram opiniōes politicas das entidades médicas AMB - Associaçăo Médica Brasileira, CFM - Conselho Federal de Medicina, FENAM - Federação Nacional dos Médicos, e ABEM - Associaçăo Brasileira de Educação Médica - contrárias à expansão. Não são poucos os registros documentais que revelam posiçōes desfavoráveis e até críticas, culpando a política adotada nos anos de 1960 e explicitando o desequilibrio existente hoje entre oferta $\mathrm{e}$ demanda, a desvalorizaçăo do profissional e má qualidade do ensino. (Machado, 1996:149)

Por outro lado, Rego (1994:48-61) mostra que a corporação, em que pese a situação política de então e a criação da Comissão de Ensino Médico no âmbito do Ministério da Educação e Cultura (MEC), furtou-se a criar, na época, mecanismos formais (da corporação ou do Estado) que regulassem o processo de formação de médicos. A política empreendida pelas lideranças de então era semelhante àquela historicamente assumida pela corporação: linha auxiliar e cooperativa do Estado, sem que contestaçōes mais veementes fossem encaminhadas pelas organizações oficiais da corporaçăo. ${ }^{7}$

Um dos aspectos mais afetados pela expansão quantitativa do ensino superior foi, sem dúvida, a relação com o mercado de trabalho. Na realidade, este é um problema que interessa ao sistema educacional interno, e não apenas à universidade. Os padrōes de crescimento vigentes na região foram responsáveis por um ritmo de criação de empregos, que, em termos gerais, foi inferior ao da expansão escolar e da população ativa no seu conjunto. Essa rigidez foi particularmente conspícua nos setores das atividades de transformação, de tal modo que as oportunidades de emprego para as pessoas altamente educadas se restringiram cada vez mais ao setor terciário, onde o Estado ocupa o lugar mais destacado. Neste sentido, a função tradicional da universidade como formadora de profissionais independentes foi substituída por uma realidade onde a universidade habilita seus egressos a ocuparem postos assalariados, que garantem status e ganhos menores do que os esperados, sem falar na grande competiçāo a que os postulantes estarão sujeitos. A importância cada vez maior desse fenômeno provocou um processo de desvalorização dos anos de estudo, que merece alguns comentários. (Tedesco, 1995:111)

Mais recentemente, numa perspectiva de controlar e até mesmo 'reparar o mal' decorrente dessa política expansionista, surgem hoje duas propostas de avalia-

7 Os sindicatos médicos e outras associaçōes representativas que contestavam o regime militar estavam sob intervenção. 
ção do ensino médico: uma do Ministério da Educação e outra da corporação médica, consubstanciada na Cinaem. ${ }^{8}$ Com uma política de reavaliar todos os cursos universitários, o MEC propóe a elaboração de um exame (prova teórica escrita) para todos os recém-graduados, objetivando analisar, avaliar e testar a validade do conhecimento adquirido ao longo da formação profissional nas instituições acadêmicas. Embora a medicina estivesse prevista como uma das primeiras carreiras em que seria aplicado o exame profissional, a corporação médica, por meio de suas entidades, tem argumentado desfavoravelmente à realização de tal exame, enfatizando a insuficiência dessa modalidade de avaliação para um curso tão complexo. Para as entidades médicas, essa avaliação deverá nascer da própria corporação, já que o princípio da auto-regulação profissional é um dos elementos fundantes da profissão. ${ }^{9}$

\section{O PROCESSO DE ESPECIALIZAÇĀO}

O modelo de ensino estabelecido nas primeiras escolas médicas brasileiras foi o da Universidade de Coimbra após a Reforma Pombalina, ${ }^{10}$ na qual

o aspirante à carreira médica deveria saber falar latim, ter conhecimento do grego, de filosofia moral e racional, e manejar as línguas francesa e inglesa, facultativamente. Cursaria, entāo, as matérias das Faculdades de Filosofia e Matemática, matriculando-se, após exames, no curso de medicina, composto de cinco cadeiras, uma em cada ano: matéria médica e farmácia; anatomia, prática das operaçōes e arte obstétrica; instituições (teoria médica) com a prática da medicina e da cirurgia no hospital; aforismos (de Hipócrates e de Boerhaave) e continuando com a prática no hospital; prática da medicina e da cirurgia no quinto e último ano, findo o qual submetia-se a exames (...), recebendo, se aprovado, o grau de 'Bacharel em Medicina e Cirurgia'. Para obter os títulos de 'ficenciado' e de 'doutor', cumpria a repetição, por mais um ano, das cadeiras de instituiçōes e aforismos, e defesa de tese, no último caso. (Santos Filho, 1991:291)

Após a reforma do ensino médico americano, em decorrência da publicação do Relatório Flexner, e o progressivo deslocamento do modelo de referência em

8 Comissão Interinstitucional da Avaliação do Ensino Médico.

9 O projeto de avaliaçāo da CinAEM busca contemplar estes interesses acima representados, ou seja, manter o controle da qualidade da formaçăo médica e, ao mesmo tempo, responder aos apelos do Governo na perspectiva de avaliar e credenciar esses novos profissionais que se graduam nas dezenas de escolas médicas existentes hoje no País. A CinAem congrega todas as entidades médicas nacionais, os dois maiores Conselhos Regionais de Medicina (Sāo Paulo e Rio de Janeiro), a Associação Nacional de Docentes de Ensino Superior (ANDEs) e o Diretório Executivo Nacional de Estudantes de Medicina. Sua proposta, que prevê a auto-avaliação do processo do ensino-aprendizagem em cada escola é de adesão voluntária, isto é, só participam aquelas que assim o desejarem. Considerando-se que o processo envolve duas fortes corporaçōes - médicos e docentes universitários - tem-se colocado em dúvida o seu alcance efetivo. Vale questionar se estarão as corporações preparadas para romper com os princípios que as fundamentam e se autoflagelarem, ainda que em causa própria.

10 Para maiores informaçōes ver SANTOS FILHO (1991, v.1). 
educaçăo médica francês para o americano, o Brasil foi paulatinamente transformando seu currículo, culminando na Reforma Universitária de 1968. Tedesco (1995:93) analisa as reformas educacionais que ocorreram nessa época em toda a América Latina e mostra que

a partir da década de 60, pôde-se assistir a uma verdadeira avalanche educacional. A América Latina, onde os problemas reunidos no diagnóstico anterior tinham uma existência peculiar em função dos seus padröes de desenvolvimento, assimilou essas propostas e, deste modo, ocorreu uma homogeneização do discurso educacional reformista, que contrastava fortemente com a heterogeneidade de situaçōes e problemas que era preciso enfrentar.

Sendo assim, os princípios do modelo flexneriano encontraram um campo fecundo em nosso país, também impregnado pelas concepções positivistas. Foram, então, estabelecidos os estudos dos sistemas e dos órgãos isolados do corpo; a concepção de doença como processo individual, natural e biológico. Como locus estratégico e de excelência para a implantação do binômio ensino-pesquisa, foram criados os hospitais universitários.

Através de suas investigações instrumentalizadas dos órgãos e sistemas, com o apoio logistico de outras ciências, inegavelmente o hospital universitário deu uma contribuição de excelência para o desenvolvimento da medicina, tendo propiciado não só a iniciação, mas o próprio desenvolvimento das especialidades médicas. Criou condiçōes para o desenvolvimento de disciplinas básicas, como anatomia, fisiologia, microbiologia, genética e muitas outras. (Santos, 1987:87)

$\mathrm{Na}$ opinião de Tedesco (1995:93), as reformas ocorridas na América Latina sofreram grande influência externa, ou seja,

as propostas de reforma sempre foram caracterizadas por uma dinâmica imposta através de influências e exigências externas. Aldo Solari (1977) mostrou claramente a relação entre as propostas reformistas e as agências internacionais de financiamento, esclarecendo até que ponto a crise do sistema educacional da América Latina era avaliada como tal, não tanto em funçăo das exigências internas dos paises, mas do novo lugar que passava a ocupar a América Latina na divisão internacional do trabalho.

Embora fortemente influenciado pelo modelo flexneriano, o currículo médico brasileiro guarda algumas características que o diferenciam do norte-americano. $\mathrm{O}$ ingresso no curso médico americano, por exemplo, se dá somente após a passagem pelo college, curso de nível superior freqüentado imediatamente após a high school. Os que pretendem freqüentar a escola de medicina em geral freqüentam o de ciências biológicas, com duraçăo de quatro anos - dois anos de disciplinas básicas e dois em áreas profissionais. $O$ internato, embora obrigatório, só ocorre após a graduação, em um 'quinto' ano. No Brasil, mantém-se o acesso à faculdade de medicina logo após a finalização do ciclo secundário; já o curso de medicina tem a duração de seis anos 
(dois de disciplinas básicas e quatro profissionais, incluindo o internato). ${ }^{11}$ Por outro lado, foi incorporado não só o modelo de ensino-pesquisa proposto pelos hospitais universitários, como o ensino por disciplinas segundo especialidades (ou seja, têm-se disciplinas como a cardiologia, pediatria, dermatologia, radiologia etc.). Embora os conteúdos programáticos dessas disciplinas se sobreponham em diversos aspectos, eles são ministrados de forma independente, prevalecendo a lógica interna de cada disciplina ou especialidade.

Se, por um lado, esse crescente 'especialismo', sustentado pelo mito da eficácia e racionalidade técnica, encontra amplo apoio na sociedade moderna e no complexo médico-industrial, por outro, acaba favorecendo a especializaçăo precoce do estudante. Desta forma, os médicos, de modo geral, estão se formando condicionados por um mercado cada vez mais competitivo e por um modelo de ensino que favorece e estimula a opção prematura por uma especialidade. Além disso, até recentemente, verificamos a baixa regulação empreendida pelas Sociedades de Especialistas e pelo próprio Conselho Federal de Medicina quanto ao exercício da medicina especializada, facilitando a proliferaçăo de meios informais de especializaçāo.

Assim, a especialização que aparece no início de suas práticas com relativa importância para qualificar o desempenho pessoal, a partir da plena configuração da medicina tecnológica, principalmente como decorrência da presença do equipamento, mostra-se como a única via que o médico tem para firmarse profissionalmente, deslocando definitivamente o não-especialista do mercado. (Schraiber, 1993:99)

Como vimos no capítulo anterior, as especialidades que adotam o modelo cognitivo tendem a reduzir sua importância na configuração da estrutura de prestação de serviços médicos. Assumem lugar de destaque aquelas especialidades com forte apelo técnico-cirúrgico. A despeito de contarmos hoje com 64 especialidades médicas reconhecidas pelo Conselho Federal de Medicina, este número é, na verdade, muito maior. São diversas as sociedades de especialistas cujas áreas de especialização não estão ainda oficialmente reconhecidas pelo CFM. ${ }^{12}$

A Tabela 2.1 sugere um processo evolutivo de algumas especialidades aqui selecionadas, mostrando, por exemplo, a crescente produção de pediatras, de gineco-obstetras, de clínicos gerais (medicina interna) e cirurgiōes gerais. Por outro lado, as demais especialidades aqui apresentadas (cardiologia, anestesiologia, oftalmologia, psiquiatria, por exemplo) mostram um movimento de auto-regulação de sua

11 O estágio curricular no curso de Medicina é chamado de 'internato', tendo sido regulamentado pela Resolucão no. 9, de 25/5/1983, do Conselho Federal de Educação.

12 São as superespecialiades (no sentido de maior especificidade) ou subespecialidades (como uma divisão de uma especialidade). As subespecialidades, embora presentes em pequeno número na relação oficial, nāo devem ser procuradas e dimensionadas apenas na categoria 'outras' na tabela. Diversos médicos, ao preencherem os questinários, não encontrando sua especialidade listada, optaram por assinalar aquela de onde ela se originou; outros deixaram em branco, contribuindo para o montante dos 'ignorados'. 


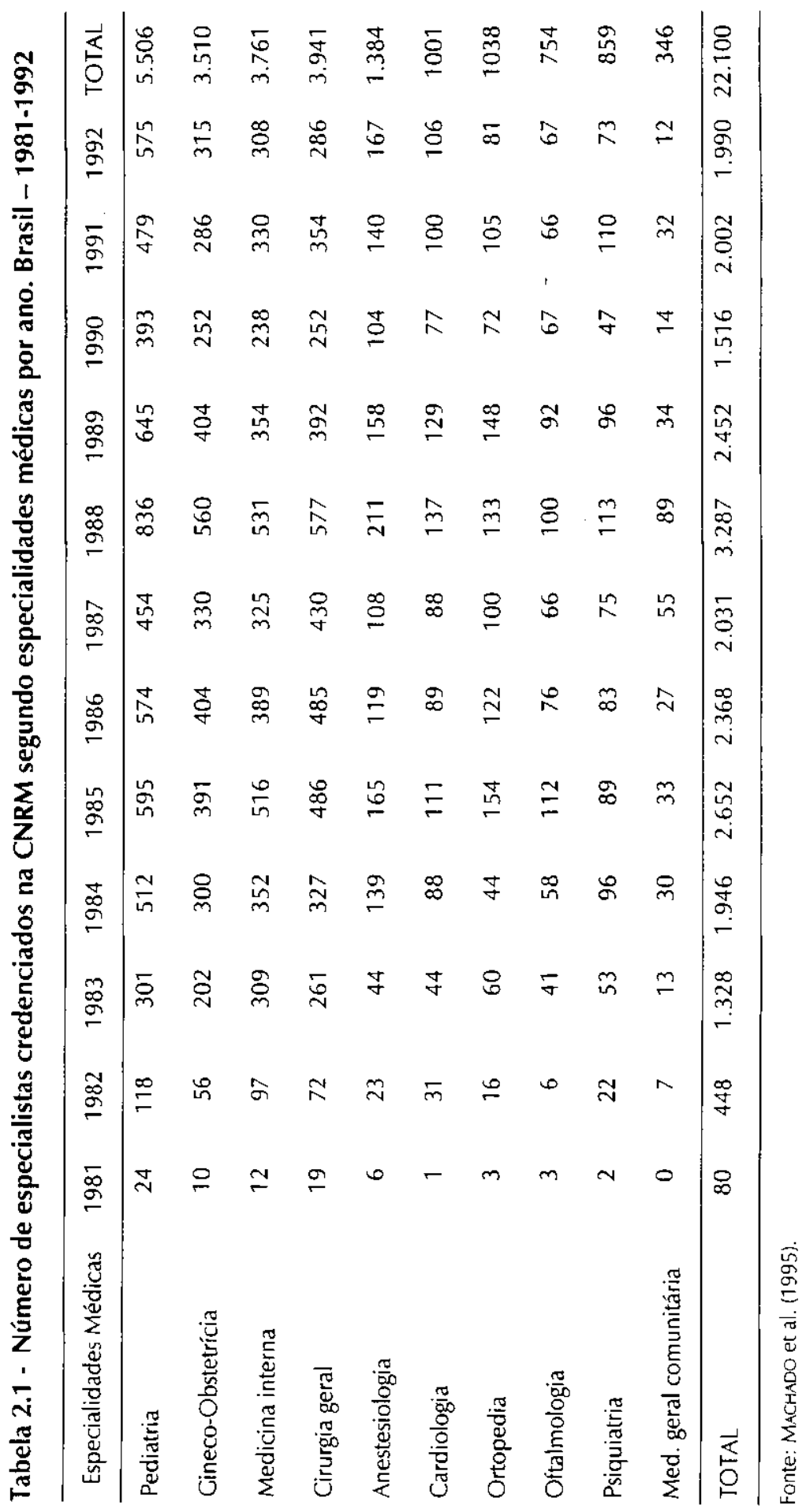


produção, não registrando o elevado crescimento experimentado pelas especialidades básicas citadas acima.

Este movimento corporativo coaduna-se com alguns dados obtidos em nossa pesquisa, como poderá ser visto no capítulo 4. Algumas especialidades caracterizam-se pela baixa adesão dos jovens profissionais; outras, ao contrário, são as que eles demandam mais fortemente, o que sugere um processo geracional na escolha da especialidade.

\section{CIÊNCIAS MÉDICAS: SEM MESTRES E DOUTORES?}

Como afirma Tedesco (1995:116), a enorme importância da pesquisa técnico-científica no desenvolvimento social mais amplo é incontestável. Neste sentido, seria a universidade responsável pela formação dos quadros de cientistas para realizar essa função. No entanto, uma das questōes cruciais que tem impedido o desenvolvimento da ciência e tecnologia nos países da América Latina, e o Brasil está incluído, é a pouca importância da nossa função de 'produtora de inovação tecnológi$\mathrm{ca}^{\prime}$. O mesmo autor (118) reitera:

a inovação técnica maior ocorre raramente na América Latina. Mesmo nos países de maior desenvolvimento industrial (Argentina, Brasil, México, por exemplo), os equipamentos utilizados são de procedência estrangeira, de tal modo que a margem que resta para a inovação local é muito reduzida. Deste ponto de vista, portanto, são mínimas as exigências do setor produtivo no sentido do desenvolvimento das atividades de pesquisa.

O setor saúde não foge a essa realidade. Equipamentos, medicamentos, técnicas e tecnologias avançadas no auxílio de diagnóstico, intervenções clínicas ou cirúrgicas são, em sua maioria, desenvolvidos e produzidos no exterior. A prática da pesquisa não se dá, de forma sistemática, nas universidades e muito menos no âmbito dos serviços. Os dados da pesquisa apontam para uma pirâmide educacional muito acentuada, fazendo uma clara divisão entre aqueles que possuem especialização lato sensu e os que têm pós-graduação stricto sensu, conformando o seguinte quadro: dos médicos graduados $74,1 \%$ fizeram curso de residência; $40,7 \%$ têm curso de especialização; apenas $7,7 \%$ atingiram o grau de mestre; e 3,7\% conseguiram obter o título de doutor (Tabela 2.2).

Embora a pós-graduação médica seja das mais antigas no País, ${ }^{13}$ a formação stricto sensu não tem tradição no Brasil. A ênfase na formação para o mercado e para os serviços sempre teve amparo na falta de políticas específicas para a produção científica na medicina e no baixo nível de exigências de escolaridade formal acadêmica que ca-

13 Entre os primeiros cursos de pós-graduação lato sensu do Brasil encontramos, em 1931, os cursos de especialização em Perícia Médico-Legal e Higiene e Saúde Pública, e, a partir da década de 50, os cursos de Residências Médicas. 


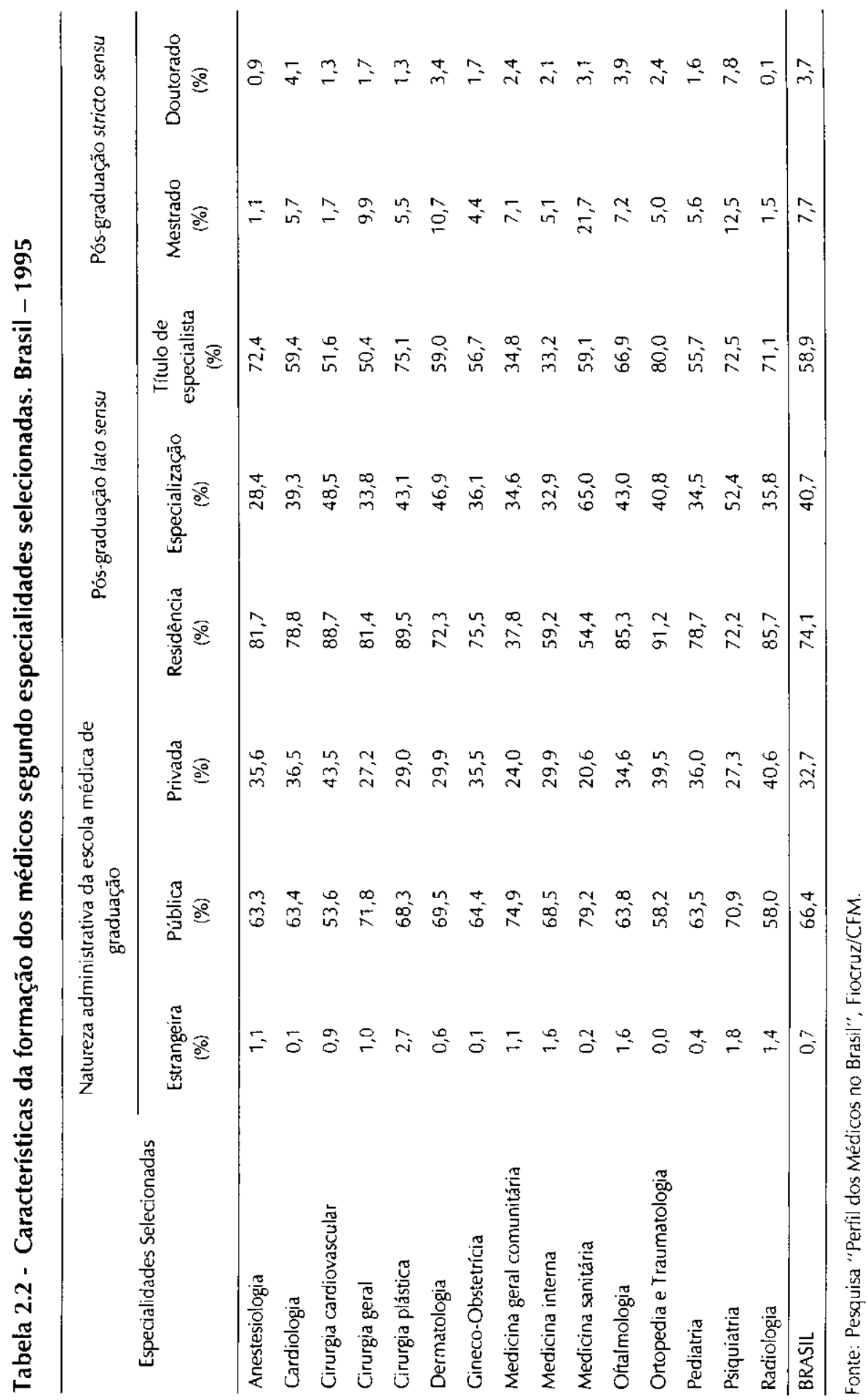


racterizou a criação e o desenvolvimento de cursos de nível superior (Sucupira, 1995:10). Somente em 1965, por meio do Parecer 977/65, o Conselho Federal de Educação regulamentou pela primeira vez a pós-graduação no Brasil. ${ }^{14}$

Mesmo assumindo que a medicina seja uma atividade profissional de seniços, não exigindo, portanto, de quem a pratica nível de especialização stricto sensu para atuar no mercado de trabalho, os dados sugerem um baixo investimento na produçāo de ciência e tecnologia (C\&T). Tal fato nāo seria grave se a medicina não fosse uma área do conhecimento que exige a renovaçáo permanente desse saber para sua aplicação na prática cotidiana do trabalho. É bom lembrar também que a medicina se tornou ciências médicas, transformando-se nessa espetacular profissão em boa parte pela extraordinária revolução científica que ocorreu nos últimos dois séculos. Portanto, não é possivel conceber a medicina voltada exclusivamente para a aplicabilidade de suas técnicas por meio de especialistas. A existência de médicos mestres e doutores representa, na verdade, um esforço inicial para aprimorar e produzir novos conhecimentos no campo das ciências médicas. Não desmerecendo os cientistas não-titulados, em última instância, esses 'doutores da medicina' (menos de $4 \%$ do contingente profissional) é que estariam 'aptos' academicamente - assim define a política de C\&T do Conselho Nacional de Pesquisas - para produzir ciência, Com isso, nảo estamos advogando em causa de uma medicina acadêmica, mas buscando promover um debate sobre a importância de pensar mais seriamente no papel e na natureza dessas instituições de ensino e pesquisa médicas (hospitais universitários e instituições de pesquisas biomédicas, por exemplo).

As Tabelas 2.3 e 2.4 mostram não só o reduzido número de programas e áreas em mestrado e doutorado, concentrando-se em somente oito áreas - anatomia patológica, cardiologia, cirurgia geral, clínica médica, infectologia (DIP/medicina tropical), gineco-obstetrícia, pediatria e saúde coletiva (medicina sanitária) -, como a escassez de instituições de ensino e pesquisa que oferecem programas de formação de mestres e doutores em medicina. Neste cenário, destacam-se as Escolas de Medicina da Universidade de São Paulo, da Universidade Federal do Rio de Janeiro, a Escola Paulista de Medicina, a PUC de Sorocaba, a Escola de Medicina de Ribeirão Preto (USP), as Escolas de Medicina da Universidade da Bahia e de Minas Gerais.

14 Consagrada a definição da pós-graduaçōes lato e stricto sensu pela Lei 5.540/68, foram, através do Parecer 77/69, daquele Conselho, estabelecidas as suas normas de credenciamento (OLIveIRA, 1995). 
Tabela 2.3 - Distribuição dos programas de mestrado e doutorado reconhecidos pela Capes/MEC segundo especialidades. Brasil - 1992

\begin{tabular}{|c|c|c|c|}
\hline Especialidades & Mestrado & Doutorado & TOTAL \\
\hline Alergia e Imunoterapia & 1 & 0 & 1 \\
\hline Anatomia patologica e Patologia clínica & 15 & 11 & 26 \\
\hline Anestesiologia & 0 & 1 & 1 \\
\hline Cardiologia & 10 & 5 & 15 \\
\hline Cirurgia abdominal & 1 & 1 & 2 \\
\hline Cirurgia cabeça e pescoço & 1 & 0 & 1 \\
\hline Cirurgia cardiovascular & 1 & 1 & 2 \\
\hline Cirurgia experimental & 2 & 2 & 4 \\
\hline Cirurgia geral & 11 & 7 & 18 \\
\hline Cirurgia plástica & 2 & 2 & 4 \\
\hline Cirurgia torácica & 1 & 0 & 1 \\
\hline Cirurgia torácica e cardiovascular & 1 & 1 & 2 \\
\hline Clínica médica & 15 & 7 & 22 \\
\hline Dermatologia & 5 & 3 & 8 \\
\hline DIP e Medicina tropical & 10 & 7 & 17 \\
\hline Endocrinologia & 4 & 3 & 7 \\
\hline Fisiatria & 1 & 0 & 1 \\
\hline Gastroenterologia & 4 & 2 & 6 \\
\hline Gastroenterologia cirúrgica & 4 & 4 & 8 \\
\hline Gineco-Obstetrícia & 10 & 8 & 18 \\
\hline Hematologia & 2 & 2 & 4 \\
\hline Medicina legal & 1 & 1 & 2 \\
\hline Nefrologia & 5 & 2 & 7 \\
\hline Neurocirurgia & 2 & 2 & 4 \\
\hline Neurologia & 6 & 5 & 11 \\
\hline Oftalmologia & 4 & 5 & 9 \\
\hline Oncologia & 1 & 1 & 2 \\
\hline Ortopedia & 3 & 3 & 6 \\
\hline Otorrinolaringologia & 6 & 3 & 9 \\
\hline Patologia tropical & 1 & 0 & 1 \\
\hline Pediatria & 13 & 7 & 20 \\
\hline Pneumologia & 5 & 3 & 8 \\
\hline Psiquiatria & 6 & 6 & 12 \\
\hline Radiologia & 3 & 3 & 6 \\
\hline Reumatologia & 2 & 2 & 4 \\
\hline Saúde coletiva & 13 & 6 & 19 \\
\hline Urologia & 3 & 2 & 5 \\
\hline TOTAL & 175 & 118 & 293 \\
\hline
\end{tabular}

Fonte: CAPES/MEC, 1992. In: MACHADO et al. (1995). 
Tabela 2.4 - Médicos com doutorado segundo instituição formadora de origem. Brasil - 1995

\begin{tabular}{|c|c|c|}
\hline Escolas Médicas & v. abs. & $(\%)$ \\
\hline Faculdade de Medicina/Universidade de São Paulo & 915 & 13,4 \\
\hline $\begin{array}{l}\text { Centro de Ciências Médicas/Faculdade de Medicina/Universidade } \\
\text { Federal do Rio de Janeiro }\end{array}$ & 613 & 9,0 \\
\hline Escola Paulista de Medicina & 585 & 8,6 \\
\hline $\begin{array}{l}\text { Centro de Ciências Médicas e Biológicas de Sorocaba/Pontifícia } \\
\text { Universidade Católica de São Paulo }\end{array}$ & 479 & 7,0 \\
\hline $\begin{array}{l}\text { Faculdade de Medicina de Ribeirăo Preto/Universidade de São } \\
\text { Paulo }\end{array}$ & 367 & 5,4 \\
\hline Faculdade de Medicina/Universidade Federal da Bahia & 343 & 5,0 \\
\hline Faculdade de Medicina/Universidade Federal de Minas Gerais & 322 & 4,7 \\
\hline Faculdade de Ciências Médicas da Santa Casa de São Paulo & 233 & 3,4 \\
\hline Faculdade de Medicina/Universidade Federal do Rio Grande do Sul & 222 & 3,2 \\
\hline Centro de Ciências da Saúde/Universidade Federal do Ceará & 220 & 3,2 \\
\hline Faculdade de Medicina do Triângulo Mineiro & 189 & 2,8 \\
\hline Escolas Médicas Estrangeiras & 180 & 2,6 \\
\hline Faculdade de Medicina/Universidade Estadual de Botucatu & 158 & 2,3 \\
\hline Fundação Faculdade Federal de Ciências Médicas de Porto Alegre & 140 & 2,1 \\
\hline Faculdade de Ciências Médicas/Universidade Estadual de Campinas & 143 & 2,1 \\
\hline Centro de Ciências da Saúde/Universidade Federal de Pernambuco & 136 & 2,0 \\
\hline $\begin{array}{l}\text { Escola de Medicina c Cirurgia da Universidade do Rio de Janeiro, } \\
\text { Uni-Rio }\end{array}$ & 106 & 1,5 \\
\hline Faculdade de Medicina de Jundiaí & 106 & 1,5 \\
\hline Outras & 1.275 & 18,6 \\
\hline lgnoradas & 110 & 1,6 \\
\hline TOTAL & 6.842 & 100,0 \\
\hline
\end{tabular}

Fonte: Pesquisa "Perfil dos Médicos no Brasil", Fiocruz/CFM. 


\section{RESIDÊNCIA MÉDICA: OS APRENDIZES DA MEDICINA}

Sendo a medicina um curso com características de terminalidade, a princípio o recém-formado encontra-se apto (teórica e praticamente) e legalmente habilitado para o exercício profissional. No Brasil e na maioria dos países latino-americanos, ${ }^{15}$ a terminalidade da formação médica se dá na graduação (Chaves \& Rosa, 1990:33). No entanto, por tradição, necessidade de aprimoramento ou até mesmo deficiência da formação profissional, boa parte dos jovens médicos busca a residência médica como fonte de aprendizagem, experiência e, sobretudo, uma especialização, o que facilita sua inserção no mercado de trabalho. Poderíamos dizer que, para tornar-se um 'médico apto' ao bom desempenho do ofício, recorre-se quase que invariavelmente a essa modalidade de aperfeiçoamento profissional.

Dessa forma, parece interessante tecer alguns comentários sobre esse contingente a que denominamos 'aprendizes da medicina'.

O curso de residência é uma modalidade de pós-graduação originada nos Estados Unidos no final do século XIX. Está fundamentada no princípio pedagógico do treinamento em serviço, formando especialistas. Excetuando a área da medicina sanitária, modernamente denominada saúde coletiva, a residência é uma modalidade de pós-graduação oferecida exclusivamente a médicos. Pressupõe dedicação exclusiva, bem como trabalho e envolvimento no cotidiano do hospital em que se desenvolve a formação. A idéia de residir no hospital ${ }^{16}$ implica esse envolvimento integral com as atividades realizadas rotineiramente pelo staff médico e acompanhadas pelo residente, possibilitando, assim, a 'vivência clínica'. A importância da residência sempre de grande procura e com destacado prestígio entre os médicos - pode ser compreendida pelo papel central que a experiência clínica tem na formação desse profissional e pela reconhecida deficiência das escolas médicas na promoção dessa prática. Rego (1994:109-114) vai mostrar que é, "portanto, componente essencial da transformação do estudante em médico". Becker \& Geer (1963:172) identifica a valorizaçăo da 'experiência clínica' e da 'responsabilidade médica' como parte fundamental no processo de formação médica. Segundo esse autor, é a busca por adquirir a experiência clínica com pacientes que mobiliza os alunos em período de formação. Por meio do cotidiano do fazer, do lidar com os pacientes e com a doença, o médico adquirirá a experiência clínica, fazendo, assim, a correta transposição do saber para o fazer, da teoria para a prática profissional. Assim define Becker (1984:231):

15 O estudo realizado por Chaves \& Rosa (1990) demonstra tal fato, ou seja, as respostas das associaçôes de escolas médicas que responderam ao estudo realizado no projeto "Educaçāo Médica nas Américas".

16 Em nosso país, devido à expansão inicial dos programas, à histórica escassez de recursos para qualquer programa de desenvolvimento de recursos humanos e à pouca atençăo dada à saúde, as moradias destinadas aos participantes dos programas sempre foram consideradas como um privilégio extemporâneo. 
Este termo refere-se à experiência clínica, a verdadeira experiência em lidar com pacientes e doenças, e o principal significado desta expressão repousa na polarização implícita com o 'aprendizado de livros'. Experiência clínica, na visão adotada para este termo, confere ao médico um conhecimento que ainda não foi sistematizado e verificado cientificamente. Não é possível adquirir este conhecimento através do estudo acadêmico - é necessário observar o fenômeno clínico e lidar com os problemas clínicos diretamente. A experiência clínica pode inclusive substituir o conhecimento comprovado cientificamente, pode ser usado para legitimar um conjunto de opçōes de procedimentos para o tratamento de um paciente e, da mesma forma, pode ser usada para contra-indicar alguns procedimentos que tenham sido estabelecidos cientificamente.

Os primeiros programas de residência médica criados no Brasil tiveram lugar no Hospital das Clínicas da Universidade de São Paulo e no Hospital dos Servidores do Estado, no Rio de Janeiro, na década de 40 (Pierantoni, 1994:7). Entre 1950 e 1960, surgiram novos programas, mas o momento de grande impulso da residência médica no Brasil se deu na década de $70 .{ }^{17}$ Tradicionalmente, em especial no âmbito do MEC, considera-se a data da criação da Comissão Nacional de Residência Médica - CNRM - (Brasil, 1977) como o marco do desenvolvimento desses programas. Mas o que ocorre, na verdade, é que esta Comissão nasceu justamente para regulamentar, controlar e padronizar o conteúdo dos inúmeros programas existentes e as condições em que eles se desenvolviam, assim como para regulamentar os cursos que começariam a funcionar a partir daquela data. Definia-se, assim, a residência médica como uma

modalidade de ensino de pós-graduaçāo, destinada a médicos, a nível de especialização, caracterizada por treinamento em serviço, em regime de dedicação exclusiva, funcionando em instituiçōes de saúde, universitárias ou não, sob orientação de profissionais médicos de elevada qualificaçāo ética e profissional. (Brasil, 1977)

A CNRM implementou outras açōes:

a) estabelecer parâmetros para a atuação do médico-residente (inclusive de jornada de trabalho e remuneração);

b) definir critérios e normas para o credenciamento dos programas.

A duração de um programa, embora varie de acordo com a especialidade, dura dois anos em geral. Entretanto, tem sido observado o aumento de sua duração, associado ou não ao desenvolvimento de subespecialidades (Machado et al., 1995). No caso de algumas especialidades, observa-se a exigência de um ou mais anos de residência numa especialidade básica (em geral, clínica médica ou cirurgia geral, dependendo do caso), seguidos de dois ou mais anos na especialidade escolhida. ${ }^{18}$

17 Para maiores informações, ver, em especial, MaCHADO et al. (1995).

18 As residências podem ter a duração de até quatro anos, principalmente, as especialidades de cirurgia cardiovascular, cirurgia pediátrica, cirurgia plástica, cirurgia vascular periférica, neurocirurgia e neurologia (MACHADO et al., 1995). 
Desta forma, para tornar-se especialista, por exemplo, em neurocirurgia, um médico poderá passar por um longo processo de formação de até quatro anos.

\section{Perfil dos aprendizes da medicina}

O contingente de médicos-residentes ${ }^{19}$ identificado na pesquisa é de 10.243 profissionais, considerando, inclusive, aqueles formados após 1990, ou seja, os que declararam estar inseridos em algum programa de residência, provavelmente como vamos demonstrar mais adiante - fazendo a segunda ou terceira opção. ${ }^{20}$

Qual seria o perfil destes 'jovens aprendizes da medicina'? Resumidamente, podemos dizer que:

a) a maioria tem menos de 29 anos de idade;

b) metade desses jovens é do sexo feminino;

c) um terço deles tem pai com formação universitária;

d) são tipicamente urbanos;

e) buscam um segundo programa de residência médica;

f) sentem necessidade de aprimoramento técnico-científico e gostariam de buscálo no exterior;

g) excetuando as áreas básicas, buscam especializar-se em oftalmologia, ortopedia e traumatologia, e cardiologia;

h) exercem suas atividades predominantemente $(90 \%)$ em instituições públicas;

i) não têm dedicação exclusiva, ou seja, desempenham duas ou três atividades de trabalho remunerado;

j) em sua maioria absoluta, têm atividade de plantão;

1) em média, têm salário de 750 dólares/mês, mas gostariam de ganhar 3.500 dólares/mês e sugerem piso salarial de 1.100 dólares/20 horas;

$\mathrm{m})$ năo se consideram profissionais liberais;

n) sentem muito desgaste no exercício profissional; e

o) vêem o futuro da profissão com incerteza e pessimismo.

Constituído em sua maioria de jovens, esse contingente médico apresenta uma expressiva presença feminina - mais da metade (Gráfico 2.2) -, evidenciando o processo de feminilização da profissão médica apontado no capítulo 1 .

19 Foi classificado como médico-residente aquele que se formou a partir de 1990 (inclusive) considerando-se 1993 o ano-base do cadastro da pesquisa - e que tenha preenchido o item 'Pós-graduação - Residência' no questionário. Para mais detalhes, ver: MACHADO et al. (1996, v.1).

20 A comparação pode ser feita com as informaçōes relativas ao número de concluintes registrados pela Comissăo Nacional de Residência Médica, cujos dados foram consolidados por MACHADO et al. (1995). 


\section{Gráfico 2.2 - Médicos residentes distribuídos por gênero. Brasil - 1995}

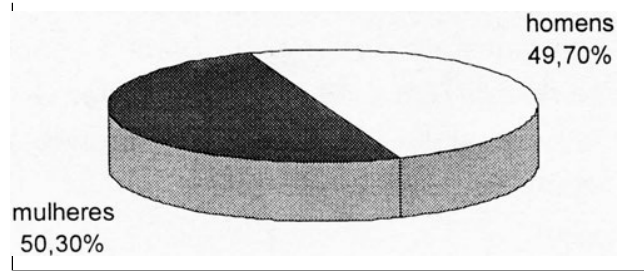

Fonte: Pesquisa "Perfil dos Médicos no Brasil", Fiocruz/CFM.

Da mesma forma, evidencia-se a crescente elevaçäo da escolaridade dos pais desses jovens médicos, mostrando que as camadas de população mais educadas têm crescido e assumido posição de destaque no mundo do trabalho - tendência verificada em países como os Estados Unidos e apontada por Larson (1980). Como mostrado anteriormente, a origem social dos médicos tem se alterado: esses profissionais são mais urbanos, mais educados e de uma camada social mais intelectualizada, diferentemente das gerações anteriores aos anos 50 , quando predominavam médicos filhos de famílias abastadas, de origem rural, com menor nível de escolaridade e reduzida inserção no mundo social urbano. Hoje, mais de um terço dos médicos-residentes é filho de profissionais liberais, com destaque para aqueles que descendem de linhagem médica.

Não fugindo à regra, médicos oriundos da classe média urbana com elevado grau de educação buscam firmar-se profissionalmente nos grandes centros. São pou$\cos$ os jovens médicos que se encontram no interior do País. Em sua maioria $(79,8 \%)$, eles vivem e buscam trabalho nas capitais (Tabela 2.5 ).

Tabela 2.5 - Médicos residentes segundo grandes regióes. Brasil - 1995

\begin{tabular}{lcccc}
\hline \multirow{2}{*}{ Brasil e Grandes Regiōes } & \multicolumn{2}{c}{ Residentes } & \multicolumn{2}{c}{ Total de médicos } \\
\cline { 2 - 5 } & v. abs. & \multicolumn{1}{c}{$(\%)$} & v. abs. & $(\%)$ \\
\hline Norte & 93 & 0,9 & 5.698 & 3,1 \\
Nordeste & 1.167 & 11,4 & 29.249 & 16,0 \\
Sudeste & 6.851 & 66,9 & 107.565 & 58,8 \\
Sul & 1.318 & 12,9 & 28.108 & 15,4 \\
Centro-Oeste & 814 & 7,9 & 12.432 & 6,8 \\
\hline BRASIL - TOTAL & 10.243 & 100,0 & 183.052 & 100,0 \\
\hline BRASIL - Capitais & 8.170 & 79,8 & 120.662 & 65,9 \\
\hline BRASIL - Interiores & 2.073 & 20,2 & 62.390 & 34,1 \\
\hline
\end{tabular}

Fonte: Pesquisa "Perfil dos Médicos no Brasil", Fiocruz/CFM. 
Reforçando nossa argumentação sobre a antipolítica de interiorização dos serviços médicos, observa-se que quase todos os programas - e, em conseqüência, os residentes - estão concentrados em duas regióes onde a economia brasileira tem o maior PIB: Sul e Sudeste detêm $78,9 \%$ de todos os programas de residência do País (de natureza pública em sua maioria absoluta), concentrando, dessa forma, na mesma proporção o contingente de residentes (Tabela 2.6).

Tabela 2.6 - Distribuição dos programas de residência médica segundo grandes regióes. Brasil - 1992

\begin{tabular}{lcc}
\hline \multirow{2}{*}{ Brasil e Grandes Regiōes } & \multicolumn{2}{c}{$\begin{array}{c}\text { No de Programas de } \\
\text { Residência Médica }\end{array}$} \\
\cline { 2 - 3 } & v. abs. & $(\%)$ \\
\hline Norte & 17 & 1,1 \\
Nordeste & 194 & 12,0 \\
Sudeste & 1.047 & 64,6 \\
Sul & 233 & 14,3 \\
Centro-Oeste & 130 & 8,0 \\
\hline BRASIL & 1.621 & 100,0 \\
\hline
\end{tabular}

Fonte: MaCHADO et al. (1995).

\section{Definindo a inserção no mercado de serviços médicos}

Mesmo estando esses médicos em processo de profissionalizaçăo para o mercado, $13 \%$ declararam já ter concluído ao menos um curso de especialização lato sensu. Destacando-se do perfil nacional, chama-nos a atenção o fato de $26 \%$ dos médicos jovens expressarem interesse específico em fazer pós-graduação stricto sensu e quase $30 \%$ almejarem ir para o exterior em busca de um aperfeiçoamento mais avançado. A competitividade do mercado, aliada à necessidade premente de reciclagem e acompanhamento das inovações técnico-científicas, tem produzido um esforço adicional desses profissionais em busca de methor inserção num mercado de trabalho que tem demandado profissionais com perfis mais arrojados e flexíveis para lidar no próximo século com uma medicina complexa, sofisticada e com alto envolvimento tecnológico.

Os dados da Tabela 2.7 e do Gráfico 2.3 apontam dois comportamentos distintos, porém complementares: primeiro, as áreas básicas - medicina interna, cirurgia geral, gineco-obstetrícia e pediatria - compōem o quadro da metade do contingente, ou seja, dos 10.243 residentes, 5.434 realizam programas nessas quatro áreas; segundo, se isolarmos os percentuais referentes a essas quatro especialidades, 
Tabela 2.7 - Médicos residentes segundo especialidade.* Brasil - 1995

\begin{tabular}{|c|c|c|}
\hline Especialidade & v. abs. & (\%) \\
\hline Anestesiologia & 302 & 3,0 \\
\hline Broncoesofagologia & 14 & 0,1 \\
\hline Cancerologia & 104 & 1,0 \\
\hline Cardiologia & 540 & 5,3 \\
\hline Cirurgia cardiovascular & 18 & 0,2 \\
\hline Cirurgia geral & 1.505 & 14,7 \\
\hline Cirurgia pediátrica & 26 & 0,3 \\
\hline Cirurgia vascular & 242 & 2,4 \\
\hline Citopatologia & 171 & 1,7 \\
\hline Dermatologia & 173 & 1,7 \\
\hline Gineco-Obstetrícia & 900 & 8,8 \\
\hline Hematologia & 39 & 0,4 \\
\hline Infectologia & 17 & 0,2 \\
\hline Mastologia & 82 & 0,8 \\
\hline Medicina geral comunitária & 66 & 0,6 \\
\hline Medicina interna & 1.663 & 16,2 \\
\hline Medicina sanitária & 26 & 0,3 \\
\hline Nefrologia & 33 & 0,3 \\
\hline Neurocirurgia & 115 & 1,1 \\
\hline Neurofisiologia & 15 & 0,2 \\
\hline Neurologia & 65 & 0,6 \\
\hline Neurologia pediátrica & 12 & 0,1 \\
\hline Oftalmologia & 747 & 7,3 \\
\hline Ortopedia e Traumatologia & 550 & 5,4 \\
\hline Otorrinolaringologia & 168 & 1,6 \\
\hline Patologia & 30 & 0,3 \\
\hline Pediatria & 1.366 & 13,3 \\
\hline Pneumologia & 112 & 1,1 \\
\hline Psiquiatria & 231 & 2,3 \\
\hline Radiologia & 251 & 2,5 \\
\hline Reumatologia & 38 & 0,4 \\
\hline Urologia & 114 & 1,1 \\
\hline Ignorada & 508 & 5,0 \\
\hline TOTAL & 10.243 & 100,0 \\
\hline
\end{tabular}

* Corresponde à primeira opção citada pelo médico, que podia apontar até três alternativas de residência.

Fonte: Pesquisa "Perfil dos Médicos no Brasil", Fiocruz/CFM. 
notamos a predominância de áreas que envolvem cirurgia ou manuseio de equipamentos médicos (oftalmologia, ortopedia e traumatologia, cardiologia, anestesiologia e radiologia). Nosso ponto de vista é reforçado quando analisamos as informações (dados năo tabulados) sobre a 'segunda residência'. Aqui, as opçōes recaem em técnico-cirúrgicas, com destaque para cirurgia de cabeça e pescoço, cirurgia pediátrica e cirurgia cardiovascular.

\section{Gráfico 2.3 - Médicos residentes segundo especialidades selecionadas.* Brasil - 1995}

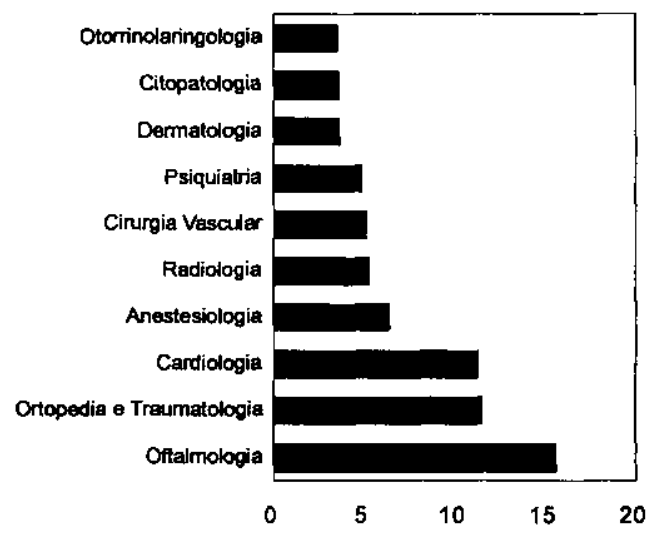

* Foram excluídas as especialidades básicas: cirurgia geral, medicina interna, pediatria e gineco-obstetrícia, que totalizaram 5.434 dos 10.243 residentes.

Fonte: Pesquisa "Perfil dos Médicos no Brasil", Fiocruz/CFM.

\section{Iniciando-se no mercado de serviços médicos}

Embora os residentes ainda estejam em processo de formação, é significativa sua participação no mundo do trabalho remunerado, o que contraria os dispositivos legais do programa de residência, que exige dedicação exclusiva. Mais da metade dos residentes tem entre duas e três atividades concomitantes à sua formação, o que caracteriza o abandono, na prática, do requisito 'dedicação exclusiva' do programa de residência (Gráfico 2.4).

Além do múltiplo emprego, outro fato que reforça ainda mais a perda da importância da residência como um programa de formação profissional é o elevado número de 'médicos em formação' que tem atividades como 'profissionais liberais'. Nada menos do que 3.446 (34\%) deles informam realizar também atividades em consultórios particulares. É bom registrar que nem mesmo o sistema de pré-pagamento (medicina de grupo, cooperativas e seguro-saúde), que afirma possuir eficazes mecanismos de controle de seus 'cooperados', exerce alguma ação discriminató- 
Gráfico 2.4 - Médicos residentes segundo número de atividades. Brasil - 1995

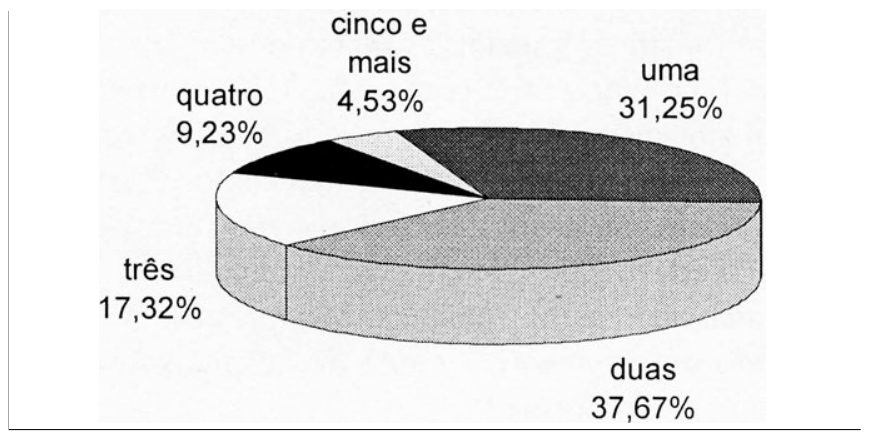

Fonte: Pesquisa "Perfil dos Médicos no Brasil", Fiocruz/CFM.

ria sobre esses profissionais ainda em fase de especialização, embora $60 \%$ dos que têm atividade em consultório estejam vinculados a esse sistema. Outro dado importante no reforço da perda da dedicação exclusiva é o fato de a maioria absoluta afirmar que faz plantão, o que constitui uma forma flexível de ter 'outra atividade' remunerada sem interferir abertamente na rotina cotidiana do residente (Gráfico 2.5).

\section{Gráfico 2.5 - Médicos residentes segundo atividade em plantão. Brasil - 1995}

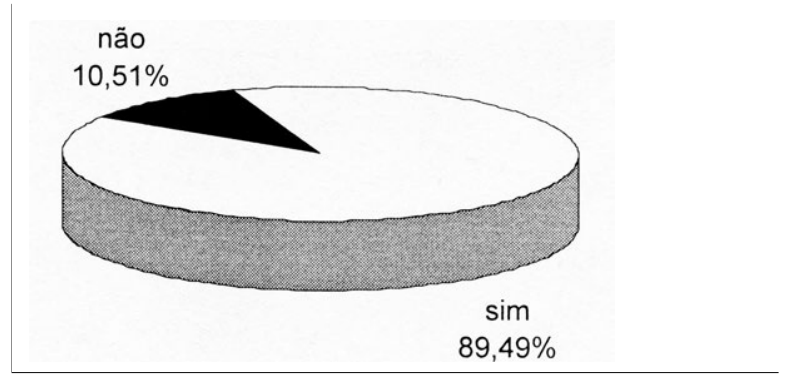

Fonte: Pesquisa "Perfil dos Médicos no Brasil", Fiocruz/CFM.

Vale ressaltar que foram os médicos-residentes os primeiros a se organizar politicamente no contexto pouco favorável da década de 70 . Organizando-se em movimentos grevistas, eles passaram a denunciar não só as condiçōes de trabalho a que estavam submetidos quando de sua formação, como também a fraca relação alunopreceptor que efetivamente acontecia no interior dos hospitais-escolas. As primeiras greves dos médicos-residentes serviram para demonstrar de forma inequívoca a participação estratégica que tinham no atendimento hospitalar - como responsáveis pelo 'atendimento em massa' -, caracterizando-se, então, a equivocada e eticamen- 
te comprometida substituição do mestre pelo aprendiz de medicina. Acostumados a ser utilizados como mão-de-obra de baixo custo, os médicos-residentes passaram a reivindicar prerrogativas trabalhistas típicas de um trabalhador assalariado: salário fixo nacional (que funcionaria como uma 'bolsa de estudos', indexado ao salário de professor universitário), direito a férias remuneradas, delimitação de jornada de trabalho semanal e benefícios previdenciários. Por um lado, as reivindicações foram vitoriosas, mas, por outro, implicaram um rápido e progressivo reordenamento da oferta de programas nessa modalidade. Várias instituiçōes, quase sempre privadas, adotaram a política de supressão de seus programas de residência, reduzindo sensivelmente a oferta de hospitais responsáveis pela formação de contingente recém-formado. ${ }^{21}$

A situação na atualidade não se alterou. Pelo contrário, o desgaste e o estresse diários somam-se às longas e exaustivas jornadas de trabalho a que esses 'aprendizes da medicina' estão submetidos, muito mais inseridos e assumindo as responsabilidades de um profissional mais experiente (Gráfico, 2. 6).

\section{Gráfico 2.6 - Médicos residentes segundo desgaste profissional. Brasil - 1995}

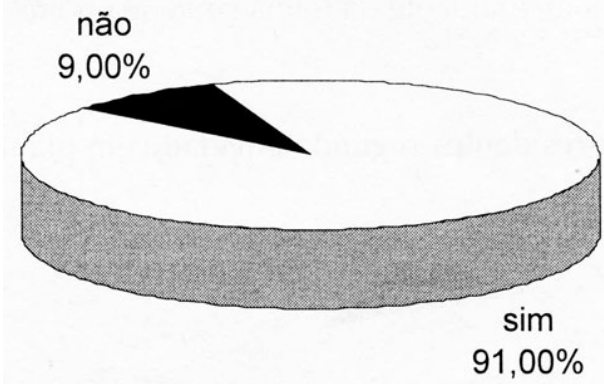

Fonte: Pesquisa "Perfil dos Médicos no Brasil", Fiocruz/CFM.

Alheio às rápidas mudanças que ocorriam na residência médica, pouco a pouco o movimento de médicos-residentes se distanciou dos aspectos ligados à formação profissional propriamente dita e centrou-se de forma exagerada nas questões concernentes ao mundo do trabalho. De aprendizes da medicina, transformaram-se precocemente em trabalhadores da saúde, reivindicando, por exemplo, o fim da de-

21 Muitos hospitais privados, por não concordarem com o aumento das despesas com os programas de residência médica, foram, gradativamente, diminuindo as vagas oferecidas na modalidade residência médica, substituindo-as por 'de pós-graduação em cursos lato sensu em nivel de residência'. Os alunos destes cursos, ao invés de receberem uma bolsa de estudos, passavam a pagar por eles. Os cursos, por sua vez, não estavam mais obrigados a se submeter às determinaçöes e ao controle da Comissão Nacional de Residência Médica. 
dicação exclusiva ao programa de residência médica, a contagem de tempo de serviço (quando residentes) para efeito de aposentadoria e diversos outros direitos típicos da relação trabalhista, bem como sua inclusão no rol dos trabalhadores que contribuem para o Fundo de Garantia por Tempo de Serviço.

O resultado de tudo isso foi o desenvolvimento de duas estruturas e realidades distintas que atendem a essa modalidade de formação de médicos especialistas no País: de um lado, programas formais, em sua maioria abrigados em instituições públicas, que remuneram seus residentes com bolsas por vezes superiores ao salário de seus preceptores; por outro lado, programas não-formais, que funcionam quase sempre em instituições privadas, não remuneram seus residentes e não sofrem qualquer sanção do órgão fiscalizador (CNRM). No entanto, ambas as estruturas formam e credenciam médicos para o mundo do trabalho especializado.

Quadro 2.1 - Médicos formados distribuídos por escolas médicas segundo localização. Brasil - 1995

\begin{tabular}{|l|c|c|c|c|c|c|}
\hline \multicolumn{2}{|c|}{ Escolas Médicas/período de fundação } & \multirow{2}{*}{$\begin{array}{l}\text { Localização da } \\
\text { Escola }\end{array}$} & \multicolumn{3}{|c|}{ Médicos formados } \\
\cline { 5 - 7 } & \multicolumn{2}{|c|}{ capital } & interior & TOTAL \\
\hline 1808 - 1929 & BA & capital & 4.103 & 1.256 & 5.359 \\
\hline $\begin{array}{l}\text { Faculdade de Medicina/Universidade Federal } \\
\text { da Bahia }\end{array}$ & & & & & \\
\hline $\begin{array}{l}\text { Centro de Ciências da Saúde - Faculdade de } \\
\text { Medicina/Universidade Federal do Rio de } \\
\text { Janeiro }\end{array}$ & RJ & capital & 8.321 & 1.325 & 9.646 \\
\hline $\begin{array}{l}\text { Faculdade de Medicina/Universidade Federal } \\
\text { do Rio Grande do Sul }\end{array}$ & RS & capital & 3.708 & 1.648 & 5.356 \\
\hline $\begin{array}{l}\text { Escola de Medicina e Cirurgia da Universidade } \\
\text { do Rio de Janeiro (Uni-Rio) }\end{array}$ & RJ & capital & 5.102 & 504 & 5.606 \\
\hline $\begin{array}{l}\text { Setor de Ciências da S̄aúde/Universidade } \\
\text { Federal do Paraná }\end{array}$ & PR & capital & 3.508 & 3.012 & 6.520 \\
\hline $\begin{array}{l}\text { Faculdade de Medicina/Universidade de São } \\
\text { Paulo }\end{array}$ & SP & capital & 4.704 & 1.276 & 5.980 \\
\hline $\begin{array}{l}\text { Faculdade de Medicina/Universidade Federal } \\
\text { de Minas Gerais }\end{array}$ & MG & capital & 6.216 & 2.364 & 8.580 \\
\hline $\begin{array}{l}\text { Centro de Ciências da Saúde/Universidade } \\
\text { Federal do Pará }\end{array}$ & PA & capital & 3.436 & 311 & 3.747 \\
\hline $\begin{array}{l}\text { Centro de Ciências da Saúde/Universidade } \\
\text { Federal de Pernambuco }\end{array}$ & PE & capital & 4.822 & 374 & 5.196 \\
\hline $\begin{array}{l}\text { Faculdade de Medicina/Universidade Federal } \\
\text { Fluminense }\end{array}$ & RJ & interior & 1.711 & 908 & 2.619 \\
\hline
\end{tabular}


Quadro 2.1 - Médicos formados distribuídos por escolas médicas segundo localização. Brasil - 1995 (continuação)

\begin{tabular}{|c|c|c|c|c|c|}
\hline \multirow{2}{*}{ Escolas Médicas/período de fundação } & \multirow{2}{*}{\multicolumn{2}{|c|}{$\begin{array}{l}\text { Localizaçăo da } \\
\text { Escola }\end{array}$}} & \multicolumn{3}{|c|}{ Médicos formados } \\
\hline & & & capital & interior & TOTAL \\
\hline \multicolumn{6}{|l|}{$1930-1949$} \\
\hline Escola Paulista de Medicina & SP & capital & 3.167 & 834 & 4.001 \\
\hline $\begin{array}{l}\text { Faculdade de Ciências Médicas/Universidade } \\
\text { Estado do Rio de Janeiro }\end{array}$ & RJ & capital & 2.743 & 698 & 3.441 \\
\hline $\begin{array}{l}\text { Centro de Ciências da Saúde/Universidade } \\
\text { Federal do Ceará }\end{array}$ & CE & capital & 3.637 & 170 & 3.807 \\
\hline \multicolumn{6}{|l|}{$1950-1959$} \\
\hline $\begin{array}{l}\text { Faculdade de Ciências Médicas de } \\
\text { Pernambuco/Fundação Universidade de } \\
\text { Pernambuco }\end{array}$ & $\mathrm{PE}$ & capital & 2.638 & 439 & 3.077 \\
\hline $\begin{array}{l}\text { Centro de Ciências Médicas e Biológicas de } \\
\text { Sorocaba/Pontifícia Universidade Católica de } \\
\text { Săo Paulo }\end{array}$ & SP & interior & 1.727 & 1.553 & 3.280 \\
\hline $\begin{array}{l}\text { Centro de Ciências da Saúde/Universidade } \\
\text { Federal de Alagoas }\end{array}$ & $\mathrm{AL}$ & capital & 1.446 & 28 & 1.474 \\
\hline $\begin{array}{l}\text { Faculdade de Ciências Médicas de Minas } \\
\text { Gerais/Fundação Educacional Lucas Machado }\end{array}$ & MG & capital & 1.608 & 608 & 2.216 \\
\hline $\begin{array}{l}\text { Faculdade de Medicina de Ribeirão Preto/ } \\
\text { Universidade de São Paulo }\end{array}$ & SP & interior & 484 & 1.816 & 2.300 \\
\hline $\begin{array}{l}\text { Escola de Medicina e Saúde Pública/Fundação } \\
\text { Bahiana para Desenvolvimento da Medicina }\end{array}$ & $\mathrm{BA}$ & capital & 2.929 & 954 & 3.883 \\
\hline $\begin{array}{l}\text { Faculdade de Medicina/Universidade Federal } \\
\text { de Juiz de Fora }\end{array}$ & MG & interior & 1.432 & 2.311 & 3.743 \\
\hline Faculdade de Medicina do Triângulo Mineiro & $M G$ & interior & 654 & 1.029 & 1.683 \\
\hline $\begin{array}{l}\text { Centro de Ciências da Saúde/Universidade } \\
\text { Federal de Santa Maria }\end{array}$ & RS & interior & 846 & 1.954 & 2.800 \\
\hline $\begin{array}{l}\text { Centro de Ciências da Saúde/Universidade } \\
\text { Federal da Paraíba. Campus I }\end{array}$ & PB & capital & 2.088 & 756 & 2.844 \\
\hline $\begin{array}{l}\text { Centro de Ciências da Saúde/Universidade } \\
\text { Federal do Rio Grande do Norte }\end{array}$ & $\mathrm{RN}$ & capital & 1.494 & 58 & 1.552 \\
\hline $\begin{array}{l}\text { Centro de Ciências Biomédicas/Pontifícia } \\
\text { Universidade Católica do Paraná }\end{array}$ & $P R$ & capital & 777 & 606 & 1.383 \\
\hline $\begin{array}{l}\text { Centro de Ciências da Saúde/Fundaçāo } \\
\text { Universidade Federal do Maranhāo }\end{array}$ & MA & capital & 1.637 & 532 & 2.169 \\
\hline $\begin{array}{l}\text { Centro Biomédico/Universidade Federal do } \\
\text { Espírito Santo }\end{array}$ & ES & capital & 1.203 & 907 & 2.110 \\
\hline
\end{tabular}


Quadro 2.1 - Médicos formados distribuídos por escolas médicas segundo localização. Brasil - 1995 (continuação)

\begin{tabular}{|c|c|c|c|c|c|}
\hline \multirow{2}{*}{ Escolas Médicas/período de fundação } & \multirow{2}{*}{\multicolumn{2}{|c|}{$\begin{array}{l}\text { Localização da } \\
\text { Escola }\end{array}$}} & \multicolumn{3}{|c|}{ Médicos formados } \\
\hline & & & capital & interior & TOTAL \\
\hline \multicolumn{6}{|l|}{$1960-1969$} \\
\hline $\begin{array}{l}\text { Faculdade de Ciências da Saúde/Universidade } \\
\text { Federal de Goiás }\end{array}$ & $\mathrm{CO}$ & capital & 1.926 & 639 & 2.565 \\
\hline $\begin{array}{l}\text { Centro de Ciências da Saúde/Universidade } \\
\text { Federal de Santa Catarina }\end{array}$ & SC & capital & 1.132 & 796 & 1.928 \\
\hline $\begin{array}{l}\text { Centro de Ciências Biológicas e da } \\
\text { Saúde/Universidade Federal de Sergipe }\end{array}$ & $\mathrm{SE}$ & capital & 1.079 & 42 & 1.121 \\
\hline $\begin{array}{l}\text { Fundação Faculdade Federal de Ciências } \\
\text { Médicas de Porto Alegre }\end{array}$ & RS & capital & 1.661 & 555 & 2.216 \\
\hline $\begin{array}{l}\text { Faculdade de Medicina/Universidade Estadual } \\
\text { Paulista, Botucatu }\end{array}$ & SP & interior & 667 & 1.546 & 2.213 \\
\hline $\begin{array}{l}\text { Faculdade de Medicina/Fundação } \\
\text { Universidade Federal de Pelotas }\end{array}$ & RS & interior & 416 & 1.435 & 1.851 \\
\hline $\begin{array}{l}\text { Faculdade de Medicina/Universidade Católica } \\
\text { de Pelotas }\end{array}$ & RS & interior & 718 & 884 & 1.602 \\
\hline $\begin{array}{l}\text { Faculdade de Ciências Médicas/Universidade } \\
\text { Estadual de Campinas }\end{array}$ & SP & interior & 204 & 2.174 & 2.378 \\
\hline $\begin{array}{l}\text { Faculdade de Ciências Médicas da Santa Casa } \\
\text { de São Paulo/Fundação Arnaldo Vieira de } \\
\text { Carvalho }\end{array}$ & SP & capital & 1.801 & 796 & 2.597 \\
\hline $\begin{array}{l}\text { Faculdade de Ciências da Saúde/Universidade } \\
\text { do Amazonas }\end{array}$ & AM & capital & 1.168 & 332 & 1.500 \\
\hline $\begin{array}{l}\text { Curso de Medicina/Fundaçáo Universidade do } \\
\text { Rio Grande }\end{array}$ & RS & interior & 214 & 817 & 1.031 \\
\hline $\begin{array}{l}\text { Faculdade de Ciências da Saúde/Universidade } \\
\text { de Brasilia }\end{array}$ & DF & capital & 1.736 & 292 & 2.028 \\
\hline $\begin{array}{l}\text { Faculdade de Medicina de Petrópolis/ } \\
\text { Fundação Otacílio Gualberto }\end{array}$ & RJ & interior & 986 & 310 & 1.296 \\
\hline $\begin{array}{l}\text { Faculdade de Medicina de Campos/Fundaçäo } \\
\text { Benedito Pereira Nunes }\end{array}$ & RJ & interior & 584 & 604 & 1.188 \\
\hline Centro de Biociências/Universidade de Taubaté & SP & interior & 722 & 821 & 1.543 \\
\hline $\begin{array}{l}\text { Centro de Ciências da Saúde/Universidade } \\
\text { Estadual de Londrina }\end{array}$ & PR & interior & 260 & 1.011 & 1.271 \\
\hline $\begin{array}{l}\text { Centro de Ciências Biológicas e da Saúde/ } \\
\text { Fundação Universidade de Caxias do Sul }\end{array}$ & RS & interior & 270 & 648 & 918 \\
\hline
\end{tabular}


Quadro 2.1 - Médicos formados distribuídos por escolas médicas segundo localização. Brasil - 1995 (continuação)

\begin{tabular}{|c|c|c|c|c|c|}
\hline \multirow{3}{*}{$\begin{array}{l}\text { Escolas Médicas/período de fundação } \\
\text { Faculdade de Medicina de Marília/Fundaçäo } \\
\text { Municipal de Ensino Superior de Marília }\end{array}$} & \multirow{2}{*}{\multicolumn{2}{|c|}{$\begin{array}{c}\text { Localizaçăo da } \\
\text { Escola }\end{array}$}} & \multicolumn{3}{|c|}{ Médicos formados } \\
\hline & & & \multirow{2}{*}{$\frac{\text { capital }}{289}$} & \multirow{2}{*}{$\frac{\text { interior }}{1.233}$} & \multirow{2}{*}{$\frac{\text { TOTAL }}{1.522}$} \\
\hline & $\mathrm{SP}$ & interior & & & \\
\hline $\begin{array}{l}\text { Centro de Ciências Biológicas e da Saúde/ } \\
\text { Universidade Federal da Paraíba. Campus If }\end{array}$ & PB & interior & 749 & 454 & 1.203 \\
\hline $\begin{array}{l}\text { Escola de Ciências Médicas de Volta Redonda/ } \\
\text { Fundação Oswaldo Aranha }\end{array}$ & RJ & interior & 615 & 245 & 860 \\
\hline $\begin{array}{l}\text { Faculdade de Medicina de Valença/Fundaçäo } \\
\text { Educacional D. André Arcoverde }\end{array}$ & RJ & interior & 1.706 & 586 & 2.292 \\
\hline $\begin{array}{l}\text { Centro de Ciências Biomédicas/Universidade } \\
\text { de Mogi das Cruzes }\end{array}$ & SP & interior & 1.337 & 859 & 2.196 \\
\hline $\begin{array}{l}\text { Fundação Faculdade Regional de Medicina de } \\
\text { São José do Rio Preto }\end{array}$ & SP & interior & 67 & 1.586 & 1.653 \\
\hline $\begin{array}{l}\text { Faculdade de Ciências Médicas Dr. José } \\
\text { Antônio Garcia Coutinho/Fundação de Ensino } \\
\text { Superior do Vale do Sapucaí }\end{array}$ & MG & interior & 665 & 767 & 1.432 \\
\hline $\begin{array}{l}\text { Curso de Medicina/Universidade Federal de } \\
\text { Mato Grosso }\end{array}$ & MT & capital & 213 & 17 & 230 \\
\hline $\begin{array}{l}\text { Escola de Medicina de Santa Casa de } \\
\text { Misericórdia de Vitória }\end{array}$ & ES & capital & 942 & 1.290 & 2.232 \\
\hline $\begin{array}{l}\text { Centro de Ciências da Saúde/Universidade } \\
\text { Federal do Piauí }\end{array}$ & $\mathrm{PI}$ & capital & 733 & 20 & 753 \\
\hline $\begin{array}{l}\text { Centro de Ciências Biomédicas/Fundação } \\
\text { Universidade Federal de Uberlândia }\end{array}$ & MC & interior & 312 & 1.342 & 1.654 \\
\hline $\begin{array}{l}\text { Faculdade de Medicina de Itajubá/Associação } \\
\text { de Integração Social de Itajubá }\end{array}$ & MG & interior & 577 & 858 & 1.435 \\
\hline $\begin{array}{l}\text { Sociedade Evangélica Beneficente de } \\
\text { Curitiba/Faculdade Evangélica de Medicina } \\
\text { do Paraná }\end{array}$ & PR & capital & 597 & 265 & 862 \\
\hline $\begin{array}{l}\text { Faculdade de Medicina/Fundação } \\
\text { Universidade de Passo Fundo }\end{array}$ & RS & interior & 494 & 636 & 1.130 \\
\hline $\begin{array}{l}\text { Faculdade de Medicina de Vassouras/ } \\
\text { Fundaçäo Severino Sombra }\end{array}$ & RJ & interior & 2.716 & 1.586 & 4.302 \\
\hline $\begin{array}{l}\text { Faculdade de Medicina do ABC/Fundação do } \\
A B C\end{array}$ & SP & interior & 1.473 & 446 & 1.919 \\
\hline Faculdade de Medicina de Jundiaí & SP & interior & 686 & 861 & 1.547 \\
\hline $\begin{array}{l}\text { Faculdade de Medicina Norte de Minas/ } \\
\text { Universidade Estadual de Montes Claros }\end{array}$ & MC & interior & 168 & 400 & 568 \\
\hline
\end{tabular}


Quadro 2.1-Médicos formados distribuídos por escolas médicas segundo localização. Brasil - 1995 (continuaçāo)

\begin{tabular}{|c|c|c|c|c|c|}
\hline \multirow{3}{*}{$\begin{array}{l}\text { Escolas Médicas/período de fundação } \\
\text { Escola de Ciências Médicas de Alagoas/ } \\
\text { Fundação Governador Lamenhas Filho }\end{array}$} & \multirow{2}{*}{\multicolumn{2}{|c|}{$\begin{array}{l}\text { Localização da } \\
\qquad \text { Escola }\end{array}$}} & \multicolumn{3}{|c|}{ Médicos formados } \\
\hline & & & \multirow{2}{*}{$\frac{\text { capital }}{1012}$} & \multirow{2}{*}{$\frac{\text { interior }}{46}$} & \multirow{2}{*}{$\begin{array}{r}\text { TOTAL } \\
1058\end{array}$} \\
\hline & $\mathrm{AL}$ & capital & & & \\
\hline \multicolumn{6}{|l|}{$1970-1979$} \\
\hline $\begin{array}{l}\text { Faculdade de Medicina de Teresópolis/ } \\
\text { Fundação Educacional Serra dos Orgãos }\end{array}$ & RJ & interior & 1.466 & 347 & 1.813 \\
\hline $\begin{array}{l}\text { Faculdade de Medicina/Pontifícia } \\
\text { Universidade Católica do Rio Grande de Sul }\end{array}$ & RS & capital & 762 & 479 & 1.241 \\
\hline $\begin{array}{l}\text { Faculdade de Medicina de Catanduva/ } \\
\text { Fundaçāo Padre Albino }\end{array}$ & $\mathrm{SP}$ & interior & 153 & 793 & 946 \\
\hline $\begin{array}{l}\text { Faculdade de Medicina de Santo Amaro/ } \\
\text { Organização Santamarense de Educação e } \\
\text { Cultura }\end{array}$ & $\mathrm{SP}$ & interior & 1.293 & 255 & 1.548 \\
\hline $\begin{array}{l}\text { Escola de Medicina/Fundação Técnico- } \\
\text { Educacional Souza Marques }\end{array}$ & RJ & capital & 1.665 & 237 & 1.902 \\
\hline $\begin{array}{l}\text { Faculdade de Medicina de Barbacena/ } \\
\text { Fundação José Bonifácio Lafayete de Andrada }\end{array}$ & MG & interior & 468 & 650 & 1.118 \\
\hline $\begin{array}{l}\text { Faculdade Estadual de Medicina do } \\
\text { Pará/Fundação Educacional do Estado do Pará }\end{array}$ & PA & capital & 895 & 123 & 1.018 \\
\hline $\begin{array}{l}\text { Faculdade de Ciências Médicas/Universidade } \\
\text { de São Francisco, Bragança }\end{array}$ & $\mathrm{SP}$ & interior & 595 & 1.009 & 1.604 \\
\hline $\begin{array}{l}\text { Fundaçāo Lusíada/Faculdade de Ciências } \\
\text { Médicas de Santos }\end{array}$ & $\mathrm{SP}$ & interior & 1.718 & 998 & 2.716 \\
\hline $\begin{array}{l}\text { Centro de Ciências Biolológicas e da Saúde/ } \\
\text { Universidade Gama Filho }\end{array}$ & RJ & capital & 1.869 & 78 & 1.947 \\
\hline $\begin{array}{l}\text { Faculdade de Ciências Médicas/Pontifícia } \\
\text { Universidade Católica de Campinas }\end{array}$ & $\mathrm{SP}$ & interior & 390 & 1.018 & 1.408 \\
\hline $\begin{array}{l}\text { Faculdade de Ciências Biológicas e da Saúde/ } \\
\text { Universidade de Nova Iguaçu }\end{array}$ & RJ & interior & 566 & 89 & 655 \\
\hline $\begin{array}{l}\text { Centro de Ciências Biológicas e da Saúde/ } \\
\text { Fundação Universidade Federal de Mato } \\
\text { Grosso do Sul }\end{array}$ & MS & capital & 724 & 211 & 935 \\
\hline \multicolumn{6}{|l|}{$1980-1990$} \\
\hline $\begin{array}{l}\text { Faculdade de Medicina Dr. Domingos } \\
\text { Leonardo Cerávolo/Universidade Oeste } \\
\text { Paulista }\end{array}$ & SP & interior & 17 & 0 & 17 \\
\hline $\begin{array}{l}\text { Faculdade de Ciências Médicas/Universidade } \\
\text { de Alfenas (Unifenas) }\end{array}$ & MG & interior & $*$ & $*$ & * \\
\hline
\end{tabular}


Quadro 2.1 - Médicos formados distribuídos por escolas médicas segundo localização. Brasil - 1995 (continuação)

\begin{tabular}{|l|r|r|r|r|r|r|}
\hline \multicolumn{1}{|c|}{ Escolas Médicas/período de fundação } & \multirow{2}{*}{$\begin{array}{c}\text { Localização da } \\
\text { Escola }\end{array}$} & \multicolumn{3}{|c|}{ Médicos formados } \\
\cline { 4 - 7 } & & Capital & interior & TOTAL \\
\hline $\begin{array}{l}\text { Centro de Ciências Biológicas e da Saúde/ } \\
\text { Fundação Universidade Estadual de Maringá }\end{array}$ & PR & interior & $*$ & $*$ & $*$ \\
\hline $\begin{array}{l}\text { Curso de Medicina/Universidade Regional de } \\
\text { Blumenau }\end{array}$ & SC & interior & $*$ & $*$ & $*$ \\
\hline 1991 - 1997 & & & & & \\
\hline $\begin{array}{l}\text { Faculdade Federal de Roraima/Universidade } \\
\text { Federal de Rorâima }\end{array}$ & RR & capital & & $*$ & \\
\hline
\end{tabular}

* Sem informaçōes.

Fonte: Machado (1996) e Pesquisa "Perfil dos Médicos no Brasil", Fiocruz/CFM. 


\section{A ESTRUTURA DO MERCADO DE TRABALHO MÉDICO}

\section{O TRABALHO NO CONTEXTO ATUAL}

A revolução tecnológica nas diversas áreas das ciências, a globalização da economia e as grandes mudanças sociais, econômicas e políticas que estão ocorrendo em todos os países têm levado a uma reconfiguração do mundo do trabalho, afetando diretamente o comportamento dos trabalhadores. O mercado de trabalho, por sua vez, tem experimentado mudanças profundas, sofrendo crises de oferta $\mathrm{e}$ demanda, desemprego, necessidade forçada de redução de jornada de trabalho, greves. O mercado de trabalho, seja do setor primário, seja do secundário ou terciário, tem buscado responder a essa nova ordem de questōes globalizantes que afetam indistintamente os trabalhadores. Relatório divulgado pela Organização Internacional do Trabalho (OIT) sobre emprego no mundo traz um alerta quanto a esta situação tanto nos países pobres quanto ricos. Segundo esse relatório, existem atualmente quase um bilhão de desempregados e subempregados, isto é, $30 \%$ da força de trabalho, sendo que, destes, 34 milhões estão localizados em países ricos. ${ }^{1}$

Em nosso entendimento, essa nova ordem de problemas transformou-se numa questão fundamental para melhor entender a dinâmica do mercado de trabaIho. Na perspectiva do emprego, observa-se atualmente o contrário do que ocorria em outros ciclos econômicos: o desemprego surge como reflexo da reestruturação produtiva, uma vez que os investimentos se deslocam, de setores intensivos em capital e mão-de-obra, para os ramos produtivos mais modernos, que passam a utilizar

1 No caso dos EUA, havia 5,8\% desempregados e, desde 1970, o salário pago ao trabalhador urbano vem sendo reduzido sistematicamente ("Um bilhão de desempregados". Veja. 14/06/95). Segundo relatório da OIT, o desemprego ameaça os grandes centros urbanos e poderá resultar em problemas sociais agudos e de difícil controle, como uma onda de violencia generalizada ("Desemprego ameaça cidades, adverte OIT". O Estado de São Paulo, 29/05/96). 
largamente tecnologia avançada (máquinas e equipamentos), bem como se intensificam a gestāo e o controle dentro das fábricas. ${ }^{2}$

O desemprego é estrutural, uma vez que nāo há mais demanda por uma massa de trabalhadores semiqualificados, que perderam seus postos de trabalho devido à adoção de novas tecnologias na produção. (Souza, 1997:41)

Stotz \& Giovanella (1996:125) mostram que o índice de desemprego nos países desenvolvidos tem crescido: na Alemanha, por exemplo, esse índice, em 1996, era de 9,0\%; na França, de 11,6\%; na Itália, de 12,4\%, e na Espanha, 22,6\%.

No Brasil, a situação não é diferente, de acordo com dados do Instituto Brasileiro de Geografia e Estatística (IBGE): o desemprego passou de 3,4\% em 1994 para 4,4\% em 1995, acompanhado de uma redução generalizada de salários, demonstrando, assim, clara deterioração das condiçōes de trabalho e vida da maioria da população brasileira. A ampliação das atividades modernas, somada à diversificação de vínculos informais de trabalho, fez do setor terciário o grande responsável pelo 'crescimento' de empregos, agregando mais da metade $(55,2 \%)$ do total de pessoas ocupadas, incluídas aí as vinculadas à assistência à saúde. No entanto, a geraçăo insuficiente de empregos coloca-se, mais do que nunca, como um dos principais problemas a serem enfrentados. Profissionais de diferentes áreas estão experimentando cotidianamente o fato de que suas habilidades pessoais não garantem mais a manutenção do emprego.

Berger \& Offe (1989), por exemplo, destacam diversas ordens de problemas que consideram fundamentais para entender a nova dinâmica do mercado de trabatho no contexto da globalização. A primeira delas refere-se à capacidade de competição internacional das chamadas high income economies, que combinam altos salários com programas sociais e controle sindical das condiçōes de trabalho. A segunda refere-se a uma certa saturação do mercado interno de produtos de consumo duráveis (automóveis, aparelhos domésticos, rádios, televisores). Uma terceira ordem de problemas é o da oferta de māo-de-obra jovem. Por fim, uma quarta ordem está associada à oferta e à demanda de força de trabalho: oferta pessoal e temporal de trabalho, produtividade e demanda de bens.

\section{A ESTRUTURA DO MERCADO DE SERVIÇOS MÉDICOS}

De modo geral, ao abordar questões referentes às atividades do setor de serviços, recorremos à correta conceituação funcional adotada por Berger \& Offe $(1991),{ }^{3}$ que considera esse setor como aquele que se insere num processo global

2 Sobre este assunto, ver o recente artigo de Stotz \& Grovanflia (1996: 123-126).

3 A definição de BERCER \& OfFe sobre mercado de serviços divide o setor em três segmentos: a) serviços comerciais; b) serviços internos à organização e c) serviços públicos e estatais. Para uma análise mais detalhada, consultar: BERGer \& OffE (1991), que descrevem o mercado de senviços, especíícando cada subsegmento. 
de reprodução de uma estrutura social - ou seja, a satisfação social e as condições físicas de sobrevivência - por meio da produçāo em si e das atividades que servem à manutenção e modificação das formas de preenchimento dessa força.

Esses serviços prestados compreendem o oferecimento de serviços de manutenção das condições físicas da vida social, dos sistemas de normas culturais e legais, a transmissão e o desenvolvimento de acervo de conhecimento de uma sociedade, seus sistemas de informação e circulação. A educaçăo, a segurança pública, os serviços de bens de consumo sociais (comércio, lazer, cultura, esporte etc.), serviços administrativos da burocracia estatal, bem como a saúde, são atividades que, na opinião de Offe, exercem "funçōes de proteção e resguardo". Portanto, são serviços entendidos como 'metatrabalho' ou trabalho reflexivo. Enfim, têm eles a função, inclusive, de dar condiçōes necessárias para que os membros da sociedade possam atuar como tais. Educaçăo e segurança da mão-de-obra operária, lazer e cultura são alguns exemplos.

O mercado de serviços em saúde faz parte dessa modalidade de prestação de bens de manutenção social a que nos referimos. De especial valor para a sociedade são os serviços médicos, que, por essa razăo, requerem proteção, atenção e controle do Estado. São estabelecidas regras e sancionadas leis protecionistas com vistas ao resguardo desses serviços, para que eles sejam prestados por profissionais reconhecidamente aptos técnica e legalmente.

Como dissemos no capítulo 1, a constituição do mercado de trabalho é uma das bases fundantes do projeto profissional da medicina, e não foi por acaso que a corporaçāo médica conseguiu construir, ao longo da história, um complexo e exclusivo mercado de serviços médicos com forte credibilidade social. Seu trabalho se insere numa estrutura organizacional de grande complexidade e exige, por sua natureza, que outros profissionais - de niveis de complexidade diferenciada - trabalhem em cooperação com sua atividade principal. Os médicos-cirurgiôes são bons exemplos dessa exigência de um aparato organizacional que se estrutura a partir de sua atividade. Freqüentemente, hospitais, ambulatórios, postos de saúde e prontos-socorros funcionam tendo o médico como centro de atividades.

No capítulo 1, tratamos também do processo de institucionalização e, conseqüentemente, da racionalização e burocratizaçăo que o setor saúde vem experimentando. No meio de todas essas transformações, a medicina também passa por mudanças. Com os custos do ato médico cada vez mais caros (fruto da revolução tecnológica) e amparado por tecnologia complexa e forte esquema organizacional, buscando 'racionalizar' freqüentemente suas açōes - equacionando custo-benefício -, o trabalho médico tem se tornado uma atividade desenvolvida cada vez mais em espaços institucionais. A institucionalização do trabalho médico é uma realidade que se afirma, levando-o, assim, a redefinir seu espaço de trabalho, suas atividades e, conseqüentemente, sua clientela, inclusive aquela que freqüenta seu consultório. 
Ao traçar a trajetória da evolução do sistema de saúde brasileiro, percebemos esse processo de institucionalização dos senviços de saúde, em particular dos serviços médicos.

Especialmente a partir da década de 80, diversos estudiosos - dentre eles, Donnangelo \& Pereira (1976); Cordeiro (1984); Luz (1984); Melo (1984); Teixeira \& Oliveira (1984); Costa (1985); Labra (1985); Singer, Campos \& Oliveira (1988) e Moysés (1986) - se dedicaram a esclarecer como se deu e consolidou o sistema de saúde brasileiro. Teríamos muito o que discutir e analisar sobre a evolução desse setor no País e a conformação do Sistema Único de Saúde (SUS). A literatura sobre o tema é vasta e competente e, para não sermos repetitivos, vamos nos ater ao momento atual, aos aspectos referentes ao mundo do trabalho médico e sua inserção na estrutura do mercado de trabalho em saúde.

O setor de saúde no Brasil está estruturado com uma rede de quase cinqüenta mil estabelecimentos de saúde com mais de quinhentos mil leitos e absorve em torno de dois milhōes de trabahhadores. Destes, mais de um milhão são profissionais que lidam diretamente com a assistência médica, composta por médicos, odontólogos, enfermeiros, farmacêuticos, atendentes, auxiliares e técnicos de enfermagem, laboratório, raios $X$, entre outros.

No Brasil, a forma como foi historicamente estruturado o modelo de assistência à saúde provocou uma efetiva divisão de 'mercados de serviços' entre as esferas pública e privada. Mais especificamente, essa rede de prestação de serviços está composta de 49.676 estabelecimentos de saúde, entre hospitais, postos e centros de saúde, prontos-socorros e ambulatórios, sendo que 27.092 estabelecimentos são públicos e 22.584 privados (IBGE-AMS, 1992). ${ }^{4}$

Nos períodos de 1980-87 e 1987-92, tanto o setor público como o privado experimentaram taxas geométricas elevadas de crescimento anual (Tabela 3.1).

O comportamento das taxas de crescimento no período 87-92 revelou um fato curioso: pela primeira vez na história recente do setor saúde, o Sudeste teve uma maior oferta de serviços na esfera privada, e experimentou o maior crescimento com taxas de $12,5 \%$ a.a. (Oliveira \& Pinto, 1996:2139).

4 A Pesquisa de Assistência Médico-Sanitária é realizada pelo IBGE anualmente e abrange todos os estabelecimentos de saúde do País, excetuando-se consultórios particulares. Os dados divulgados, embora sejam referentes a 1992, sāo os únicos disponíveis em nível nacional. 
Tabela 3.1 - Estabelecimentos de saúde distribuídos por natureza da instituição mantenedora e anos selecionados segundo grandes regióes. Brasil - 1980/1987/1992

\begin{tabular}{|c|c|c|c|c|c|}
\hline \multirow{4}{*}{$\begin{array}{l}\text { Brasil e } \\
\text { Grandes } \\
\text { Regiōes }\end{array}$} & \multicolumn{5}{|c|}{ Públicos } \\
\hline & \multicolumn{5}{|c|}{ Anos } \\
\hline & \multirow[b]{2}{*}{1980} & \multirow[b]{2}{*}{1987} & \multirow[b]{2}{*}{1992} & \multicolumn{2}{|c|}{$\Delta \%^{*}$} \\
\hline & & & & $80 / 87$ & $87 / 92$ \\
\hline BRASIL & 10.045 & 20.174 & 27.092 & 9,1 & 5,0 \\
\hline Norte & 548 & 1.643 & 2.808 & 14,7 & 9,3 \\
\hline Nordeste & 3.674 & 7.221 & 8.817 & 8,8 & 3,4 \\
\hline Sudeste & 3.833 & 6.456 & 8.721 & 6,7 & 5,1 \\
\hline Sul & 1.435 & 3.636 & 5.181 & 12,3 & 6,1 \\
\hline Centro-Oeste & 555 & 1.218 & 1.565 & 10,3 & 4,3 \\
\hline \multirow{4}{*}{$\begin{array}{l}\text { Brasil e } \\
\text { Grandes } \\
\text { Regiōes }\end{array}$} & \multicolumn{5}{|c|}{ Privados } \\
\hline & \multicolumn{5}{|c|}{ Anos } \\
\hline & & & & \multicolumn{2}{|c|}{$\Delta \%$} \\
\hline & 1980 & 1987 & 1992 & $80 / 87$ & $87 / 92$ \\
\hline BRASIL & 8.444 & 12.276 & 22.584 & 4,8 & 10,7 \\
\hline Norte & 236 & 438 & 705 & 8,0 & 8,3 \\
\hline Nordeste & 1.751 & 2.756 & 4.289 & 5,8 & 7,6 \\
\hline Sudeste & 3.699 & 5.410 & 10.996 & 4,9 & 12,5 \\
\hline Sul & 2.128 & 2.758 & 4.831 & 3,3 & 9,8 \\
\hline Centro-Oeste & 630 & 914 & 1.763 & 4,8 & 11,6 \\
\hline
\end{tabular}

* $\Delta \%=$ laxa geométrica de crescimento anual.

Fonte: Oliveira \& Pinto (1996).

As Tabelas 3.2 e 3.3 mostram, de um lado, uma rede ambulatorial predominantemente pública, constituída de postos, centros de saúde e postos de assistência médica (PAMs), destinados à prestação dos serviços em clínicas básicas. De outro lado, a hegemonia do setor privado, que responde por mais de $70 \%$ dos hospitais e por quase $80 \%$ de todos os leitos existentes no País.

Analisando-se os dados na perspectiva das políticas públicas de saúde, constata-se a inquestionável predominância da esfera privada e o 'encolhimento progressivo' do poder público na constituiçāo da estrutura hospitalar do sistema de saúde brasileiro nessas últimas décadas, configurando-se uma dependência do setor público em relação ao privado na prestação dessa modalidade de assistência à popula- 
Tabela 3.2 - Estabelecimentos de saúde distribuídos por natureza da instituição mantenedora segundo grandes regiōes. Brasil - 1992

\begin{tabular}{|c|c|c|c|c|c|c|}
\hline \multirow{3}{*}{$\begin{array}{l}\text { Brasil e } \\
\text { Grandes } \\
\text { Regiőes }\end{array}$} & \multicolumn{6}{|c|}{ Com Internação } \\
\hline & \multicolumn{2}{|c|}{ Público } & \multicolumn{2}{|c|}{ Privado } & \multicolumn{2}{|c|}{ TOTAL } \\
\hline & v. abs. & $(\%)$ & v. abs. & $(\%)$ & v. abs. & $(\%)$ \\
\hline BRASIL & 2.114 & 28,4 & 5.316 & 71,6 & 7.430 & 100,0 \\
\hline Norte & 281 & 49,2 & 290 & 50,8 & 571 & 100,0 \\
\hline Nordeste & 996 & 44,7 & 1.232 & 55,3 & 2.228 & 100,0 \\
\hline Sudeste & 460 & 18,1 & 2.087 & 81,9 & 2.547 & 100,0 \\
\hline Sul & 204 & 16,0 & 1.073 & 84,0 & 1.277 & 100,0 \\
\hline Centro-Oeste & 173 & 21,4 & 634 & 78,6 & 807 & 100,0 \\
\hline \multirow{3}{*}{$\begin{array}{l}\text { Brasil e } \\
\text { Crandes } \\
\text { Regiōes }\end{array}$} & \multicolumn{6}{|c|}{ Sem Internação } \\
\hline & \multicolumn{2}{|c|}{ Público } & \multicolumn{2}{|c|}{ Privado } & \multicolumn{2}{|c|}{ TOTAL } \\
\hline & v. abs. & $(\%)$ & v. abs. & (\%) & v. abs. & $(\%)$ \\
\hline BRASIL & 24.978 & 59,1 & 17.268 & 40,9 & 42.246 & 100,0 \\
\hline Norte & 2.527 & 85,9 & 415 & 14,1 & 2.942 & 100,0 \\
\hline Nordeste & 7.821 & 71,9 & 3.057 & 28,1 & 10.878 & 100,0 \\
\hline Sudeste & 8.261 & 48,1 & 8.909 & 51,9 & 17.170 & 100,0 \\
\hline Sul & 4.977 & 56,9 & 3.758 & 43,1 & 8.735 & 100,0 \\
\hline Centro-Oeste & 1.392 & 55,2 & 1.129 & 44,8 & 2.521 & 100,0 \\
\hline
\end{tabular}

Fonte: Oliveira \& Pinto (1996).

ção. Esse encolhimento do setor público remete a uma questão sociológica importante: o 'hospital' como locus tradicionalmente privilegiado de desenvolvimento do trabalho médico. É nele que o médico realiza a maioria de seus atos fundamentais: atividades técnico-cirúrgicas, acompanhamento e tratamento de pacientes enfermos que necessitam de hospitalização, realização de inúmeros exames e diagnósticos, entre outros. É também no ambiente hospitalar que os médicos trocam experiências clínicas, é lá que se dá a formação dos aprendizes da medicina (médicos-residentes), a reciclagem dos profissionais em geral, os encontros entre os colegas e os profissionais de áreas afins, e é no ambiente hospitalar que a maioria dos enfermeiros e da equipe de enfermagem desenvolvem suas atividades. Entretanto, a literatura produzida na década de 80 , à qual nos referimos anteriormente, mostra que o setor privado nunca teve tradição nestes aspectos: formação, troca de experiências clínicas, aprendizagem etc. A literatura revela ainda que o setor público tem negligenciado seu papel não só de provedor e produtor de serviços médicos, como também de provedor e responsável pela formação e capacitação de recursos humanos (no capítulo 2 abordamos esta questão). 
Tabela 3.3 - Evolução do número de leitos hospitalares distribuídos por tipo de instituição mantenedora segundo grandes regióes. Brasil - 1980/ $1987 / 1992$

\begin{tabular}{|c|c|c|c|c|c|}
\hline \multirow{4}{*}{$\begin{array}{l}\text { Brasil e } \\
\text { Grandes } \\
\text { Regiöes }\end{array}$} & \multicolumn{5}{|c|}{ Públicos } \\
\hline & \multicolumn{5}{|c|}{ Anos } \\
\hline & \multirow[b]{2}{*}{1980} & \multirow[b]{2}{*}{1987} & \multirow[b]{2}{*}{1992} & \multicolumn{2}{|c|}{$\Delta \%^{*}$} \\
\hline & & & & $80 / 87$ & $87 / 92$ \\
\hline BRASIL & 122.722 & 115.842 & 135.080 & $-0,7$ & 2,6 \\
\hline Norte & 6.135 & 7.828 & 11.383 & 3,1 & 6,4 \\
\hline Nordeste & 29.550 & 33.832 & 41.728 & 1,7 & 3,6 \\
\hline Sudeste & 63.408 & 50.608 & 56.482 & $-2,8$ & 1,8 \\
\hline Sul & 16.598 & 15.010 & 16.613 & $-1,2$ & 1,7 \\
\hline Centro-Oeste & 7.031 & 8.564 & 8.874 & 2,5 & 0,6 \\
\hline \multirow{4}{*}{$\begin{array}{l}\text { Brasil e } \\
\text { Grandes } \\
\text { Regiōes }\end{array}$} & \multicolumn{5}{|c|}{ Privados } \\
\hline & \multicolumn{5}{|c|}{ Anos } \\
\hline & & & & \multicolumn{2}{|c|}{$\Delta \%$} \\
\hline & 1980 & 1987 & 1992 & $80 / 87$ & $87 / 92$ \\
\hline BRASIL & 386.382 & 404.856 & 409.277 & 0,6 & 0,2 \\
\hline Norte & 8.653 & 9.664 & 11.692 & 1,4 & 3,2 \\
\hline Nordeste & 58.285 & 72.685 & 89.778 & 2,8 & 3,6 \\
\hline Sudeste & 214.390 & 212.482 & 203.895 & $-0,1$ & $-0,7$ \\
\hline Sul & 79.941 & 78.795 & 72.497 & $-0,2$ & $-1,4$ \\
\hline Centro-Oeste & 25.113 & 31.230 & 31.415 & 2,8 & 0,1 \\
\hline
\end{tabular}

* $\Delta \%=$ taxa geométrica de crescimento anual.

Fonte: Oliveira \& Pinto (1996).

Por outro lado, as recentes mudanças sócio-econômicas ocorridas no Brasil nesta última década alteraram de forma marcante a dinâmica do mercado de trabalho. $\mathrm{O}$ mercado de trabalho em saúde, com ênfase no setor público, representa uma alternativa importante para a absorção de mão-de-obra excedente de outros setores da economia. Em decorrência dessa característica, nos períodos recessivos há uma certa 'expansão', mais caracterizada por um crescimento artificial dos empregos no setor de prestação de serviços, em especial naqueles de baixa complexidade técnica. Dados do IBGE (1992) mostram que o setor saúde no Brasil acusou, no início da década de 90, um volume de empregos da ordem de mais de um milhão, o que significou a duplicação de sua capacidade de absorção em apenas uma década (Tabela 3.4). 
Tabela 3.4 - Evolução dos empregos de saúde distribuídos segundo nível de escolaridade. Brasil - 1980/1987/1992

\begin{tabular}{lcccccc}
\hline \multirow{2}{*}{$\begin{array}{c}\text { Nivel de } \\
\text { Escolaridade }\end{array}$} & \multicolumn{2}{c}{1980} & \multicolumn{2}{c}{ Anos } \\
\cline { 2 - 7 } & v. abs. & (\%) & v. abs. & (\%) & v. abs. & (\%) \\
\cline { 2 - 7 } & 197.352 & 34,4 & 290.720 & 39,7 & 451.303 & 43,6 \\
\hline Superior & 111.501 & 19,4 & 193.511 & 26,4 & 310.219 & 30,0 \\
Técnico e Auxiliar & 264.776 & 46,2 & 248.059 & 33,9 & 272.846 & 26,4 \\
Elementar* & 573.629 & 100,0 & 732.290 & 100,0 & 1.034 .368 & 100,0 \\
\hline TOTAL & &
\end{tabular}

* Foram considerados também os empregos de 'auxiliares' sem certificado.

Fonte: Teixeira et al. (1996).

Nos anos 80, a partir da crise econômica, ocorreu a expansão de empregos em saúde, explicada em parte pela adoção de

estratégias de crescimento do setor público, especialmente no campo das medidas de saúde coletiva e assistência médica. Programas como o PIASS ${ }^{5}$ criaram uma larga rede de serviços de saúde nos estados do Nordeste. Ao mesmo tempo, a intensificação dos convênios do Inamps com as redes estaduais e municipais favoreceu o crescimento das contratações para o setor público. Os períodos das eleições também representaram forte incremento no número de pessoas ocupadas nos estabelecimentos públicos de saúde. Assim, entre 1977 e 1984, o número de empregos em saúde na rede hospitalar e ambulatorial se expande a uma taxa de 7,9\% ao ano, justamente quando a crise econômica fazia declinar, em termos absolutos, o número de empregos nos setores mais dinâmicos, como a indústria. (Machado et al., 1992:42)

Nesse período, o emprego em saúde cresceu de forma mais acelerada no setor público (5,6\% a.a.) do que no privado (3,8\% a.a.). Ocorre, então, progressivamente, a perda relativa da hegemonia do setor privado na oferta e absorção de empregos. Como resultado da política de fortalecimento da rede pública - especialmente da rede ambulatorial - no final dos anos 80 e início da década de 90 , constata-se a superação da rede privada como detentora de maior volume de empregos, tornando-se o setor público o mais importante empregador. Em 1980, por exemplo, o setor privado respondia por 307.673 empregos, e o setor público por 265.956 , passando na década seguinte para 496.680 e 537.688 empregos, respectivamente (Tabela 3.5).

5 Programa de Interiorizaçāo das Ações de Saúde e Saneamento. 
Tabela 3.5 - Empregos de saúde distribuídos por ano segundo categorias profissionais. Brasil - 1980/1992

\begin{tabular}{lrrrrrr}
\hline \multicolumn{1}{c}{ Categorias } & \multicolumn{3}{c}{ Empregos públicos } & \multicolumn{2}{c}{ Empregos privados } \\
\cline { 2 - 7 } & 1980 & 1992 & $\begin{array}{c}\Delta \%^{*} \\
(80-92)\end{array}$ & 1980 & 1992 & $\begin{array}{c}\Delta \%^{*} \\
(80-92)\end{array}$ \\
\hline Médicos & 67.889 & 148.035 & 6,2 & 78.202 & 159.917 & 5,7 \\
Odontólogo & 10.829 & 28.449 & 7,7 & 5.867 & 13.060 & 6,3 \\
Enfermeiro & 9.409 & 27.081 & 8,5 & 5.749 & 14.420 & 7,3 \\
Farmacêutico & 2.238 & 3.973 & 4,5 & 2.392 & 2.935 & 1,6 \\
Nutricionista & 1.028 & 3.022 & 8,6 & 902 & 1.899 & 5,9 \\
Psicólogo & 617 & 4.990 & 17,4 & 937 & 3.300 & 10,2 \\
Assistente Social & 2.839 & 8.121 & 8,4 & 1.546 & 2.156 & 2,6 \\
Outras (superior)** & 3.530 & 10.701 & 10,1 & 3.378 & 19.244 & 14,4 \\
Tec. Laboratório & 5.618 & 11.671 & 5,8 & 3.840 & 10.450 & 8,0 \\
Téc. Raios X & 3.601 & 6.861 & 5,1 & 4.665 & 9.464 & 5,6 \\
Téc. e Aux. de Enfermagem & 36.031 & 119.963 & 9,7 & 35.449 & 92.708 & 7,7 \\
Outras (téc./aux.)** & 12.982 & 33.771 & 7,6 & 9.315 & 25.331 & 8,0 \\
Atendente & 65.625 & 63.254 & $-0,3$ & 111.266 & 79.102 & $-2,6$ \\
Parteira & 1.387 & 2.501 & 4,6 & 3.687 & 2.759 & $-2,2$ \\
Outras (elementar)** & 42.333 & 65.295 & 3,4 & 40.478 & 59.935 & 3,1 \\
\hline TOTAL & 265.956 & 537.688 & 5,6 & 307.673 & 496.680 & 3,8 \\
\hline & 2 & & & & &
\end{tabular}

* $\Delta \%=$ taxa geométrica de crescimento anual.

** Na categoria 'outras' estão incluldas: nível superior: Fisioterapeuta, Fonoaudióloga, Terapeuta Ocupacional, Bioquímico e Engenheiro Clínico; nível técnico: Higiene Dental, Reabilitação, Hematologia e Manutenção e nivel elementar: Laboratório e Reabilitação.

Fonte: Oliveira \& Campos (1996).

A expansão dos empregos públicos em saúde ocorrida nesta última década implicou uma distribuição melhor destes entre os três niveis administrativos. Com o processo da municipalização em curso, verifica-se uma efetiva expansão não só da capacidade instalada (estabelecimentos e leitos), como de empregos municipais, com taxas de crescimento da ordem de 13,9\% a.a. (Teixeira et al., 1996:152). A Tabela 3.6 mostra que, enquanto os estabelecimentos públicos federais e estaduais acusaram no período $1987-91$ um crescimento negativo (-6,3\% a.a.), os municipais apresentaram, no mesmo período, um crescimento espetacular, da ordem de 15,7\% a.a., chegando a $23,2 \%$ a.a. na região Centro-Oeste. 
Tabela 3.6 - Estabelecimentos de saúde públicos distribuídos por esfera administrativa segundo grandes regióes. Brasil - 1980/1987/1992

\begin{tabular}{|c|c|c|c|c|c|}
\hline \multirow{3}{*}{$\begin{array}{l}\text { Grandes } \\
\text { Regiões }\end{array}$} & \multicolumn{5}{|c|}{ Federais } \\
\hline & \multirow[b]{2}{*}{1980} & \multirow[b]{2}{*}{1987} & \multirow[b]{2}{*}{1992} & \multicolumn{2}{|c|}{$\Delta \%^{*}$} \\
\hline & & & & $80 / 87$ & $87 / 92$ \\
\hline BRASIL & 1.575 & 2.046 & 1.387 & 3,3 & $-6,3$ \\
\hline Norte & 186 & 360 & 323 & 8,6 & $-1,8$ \\
\hline Nordeste & 647 & 788 & 654 & 2,5 & $-3,1$ \\
\hline Sudeste & 455 & 464 & 219 & 0,2 & $-11,8$ \\
\hline Sul & 211 & 256 & 115 & 2,4 & $-12,5$ \\
\hline Centro-Oeste & 76 & 177 & 76 & 11,1 & $-13,1$ \\
\hline \multirow{3}{*}{$\begin{array}{l}\text { Grandes } \\
\text { Regiōes }\end{array}$} & \multicolumn{5}{|c|}{ Estaduais } \\
\hline & & & & \multicolumn{2}{|c|}{$\Delta \%$} \\
\hline & 1980 & 1987 & 1992 & $80 / 87$ & $87 / 92$ \\
\hline BRASIL & 5.768 & 10.381 & 7.043 & 7,7 & $-6,3$ \\
\hline Norte & 263 & 772 & 997 & 14,4 & 4,4 \\
\hline Nordeste & 1.789 & 4.220 & 3.654 & 11,3 & $-2,4$ \\
\hline Sudeste & 2.370 & 3.085 & 1.106 & 3,4 & $-15,7$ \\
\hline Sul & 993 & 1.643 & 783 & 6,5 & $-11,6$ \\
\hline Centro-Oeste & 353 & 661 & 503 & 8,2 & $-4,5$ \\
\hline \multirow{3}{*}{$\begin{array}{l}\text { Grandes } \\
\text { Regiöoes }\end{array}$} & \multicolumn{5}{|c|}{ Municipais } \\
\hline & & & & \multicolumn{2}{|c|}{$\Delta \%$} \\
\hline & 1980 & 1987 & 1992 & $80 / 87$ & $87 / 92$ \\
\hline BRASIL & 2.712 & 7.775 & 19.560 & 14,1 & 15,7 \\
\hline Norte & 99 & 512 & 1.488 & 22,8 & 19,5 \\
\hline Nordeste & 1.238 & 2.215 & 4.509 & 7,5 & 12,6 \\
\hline Sudeste & 1.008 & 3.026 & 7.396 & 14,7 & 16,1 \\
\hline Sul & 231 & 1.740 & 5.181 & 28,7 & 19,9 \\
\hline Centro-Oeste & 136 & 282 & 986 & 10,6 & 23,2 \\
\hline
\end{tabular}

* $\Delta \%=$ taxa geométrica de crescimento anual.

Fonte: Oliveira \& Pinto (1996). 
O fato de a rede municipal, em 1992, concentrar mais da metade de seus empregos no Sudeste e no Sul (12.577 dos 19.560 empregos) e uma comparação com as taxas de crescimento dessas regiōes nos períodos de 1980-87 e 1987-92 nos levam a concluir que o processo de municipalização em curso no País, embora lentamente, tem atingido seus objetivos.

O Gráfico 3.1 elucida o que acabamos de afirmar. As taxas de crescimento dos empregos municipais em todas as regiōes estão muito acima das verificadas nos empregos estaduais e federais. Merecem especial atenção as taxas de crescimento de empregos municipais apresentadas pelas regiōes Norte, Sul e Centro-Oeste $19,2 \%$ a.a., $18,2 \%$ a.a. e $16,6 \%$ a.a., respectivamente.

Gráfico 3.1 - Empregos públicos distribuídos por esfera administrativa. Brasil e Grandes Regiōes - 1980/1992
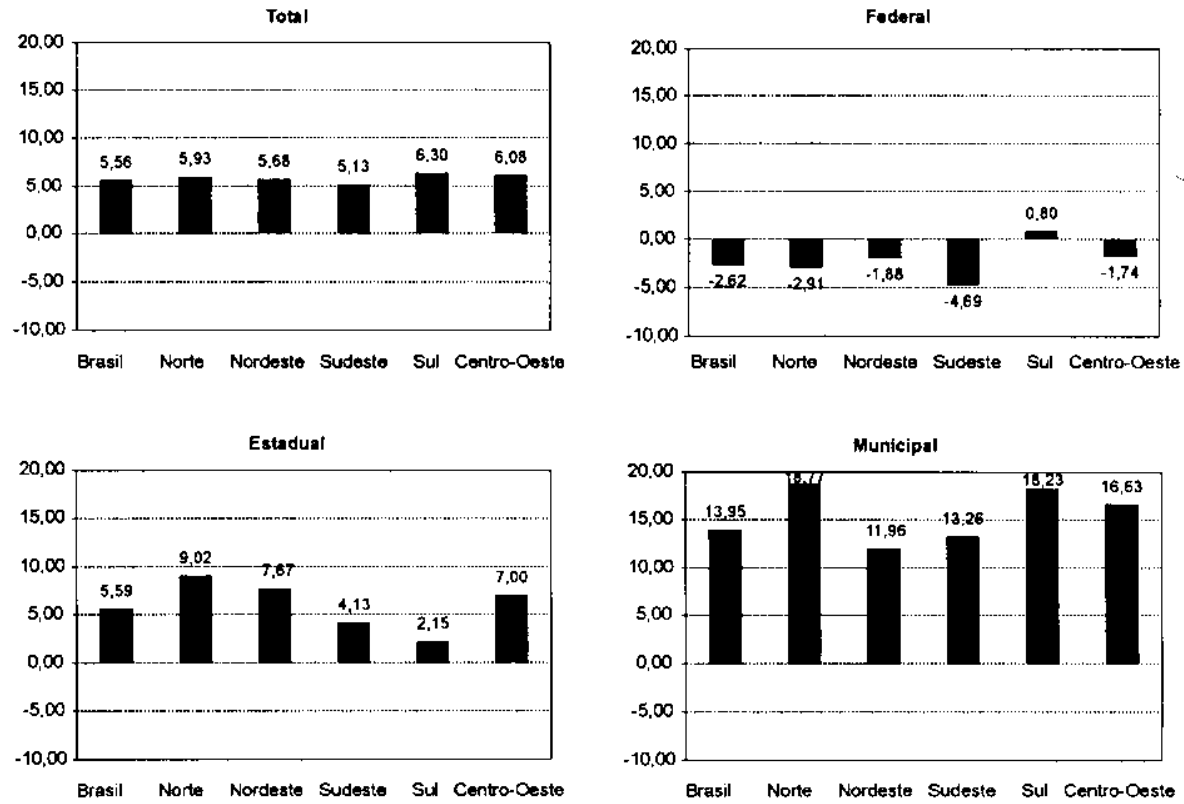

Fonte: IBGE/AMS, 1980 e 1992.

Os empregos da rede estadual também se mantiveram em crescimento em todas as regiōes, embora em nível inferior ao apresentado pela rede municipal. Com taxas de 5,6\% a.a. para o Brasil, os empregos estaduais se destacam nas regiōes Norte e Nordeste, com crescimento da ordem de $9,6 \%$ a.a. e $7,7 \%$ a.a., respectivamente.

Em situação oposta, mas coerente com a política de descentralizaçāo adotada no SUS, a rede federal vem acusando uma visível desaceleração de sua capacidade 
de gerar empregos. Os dados mostram que, no mesmo período analisado, este setor apresentou taxas negativas $(-2,6 \%$ a.a. $)$, com maior visibilidade deste fenômeno no Sudeste $(-4,7 \%$ a.a. $)$, região de tradicional geração de empregos federais.

\section{INSERÇĀO INSTITUCIONAL DOS MÉDICOS: A SITUAÇĀO DO MERCADO}

O mercado de trabalho médico é estruturado tipicamente numa correlaçāo equilibrada entre as redes pública e privada e os tradicionais consultórios particulares. A pesquisa "Perfil dos Médicos no Brasil" retratou essa realidade fielmente, mostrando-se coerente com os dados divulgados pelo IBGE, aos quais já nos referimos.

Esse mercado de serviços médicos apresenta algumas características que merecem atenção especial (Quadro 3.1).

\section{Quadro 3.1 - Características do mercado de trabalho médico. Brasil - 1995}

\begin{tabular}{|l|c|}
\hline \multicolumn{1}{|c|}{ Características } & $(\%)$ \\
\hline Setor público & 69,7 \\
Setor privado & 59,3 \\
Consultório & 74,7 \\
\hline Capital & 65,9 \\
Interior & 34,1 \\
\hline Masculino & 67,3 \\
Feminino & 32,7 \\
\hline Menos de 45 anos & 65,8 \\
\hline
\end{tabular}

Fonte: Pesquisa "Perfil dos Médicos no Brasil", Fiocruz/CFM.

Uma primeira característica é a 'homogeneidade' quanto ao comprador ou demandante de serviços, ou seja, as esferas pública e privada e os consultórios particulares ofertam serviços, mostrando-se de igual importância para o mercado de trabalho médico. A pesquisa revela que $69,7 \%$ dos médicos atuam em estabelecimentos públicos; $59,3 \%$ em estabelecimentos privados, e 74,7\% mantêm atividades em consultórios particulares.

Outra característica desse mercado é o crescente aumento da participação feminina, o que, em futuro próximo, vai implicar mudanças significativas tanto na estrutura da produção dos serviços prestados como na conformação do mercado de trabalho médico especializado.

Uma terceira característica é a constituição etária desse mercado, formado por um enorme contingente de profissionais com menos de 45 anos de idade, ou seja, $65,8 \%$ exercem a profissāo há menos de 15 anos. 
A 'urbanização' é outra característica, ou seja, $65,9 \%$ dos médicos estão atuando nas capitais brasileiras, em especial naquelas mais desenvolvidas social e economicamente, reforçando em muito a concentração desigual dos recursos humanos em saúde. Como veremos mais adiante, a medicina no Brasil vem se tornando uma prática de grandes centros urbanos, com freqüência realizada por médicos altamente especializados, voltados para uma clientela urbana. A Tabela 1.3 (capítulo 1) demonstra esse fenômeno de urbanizaçăo, acompanhado de uma má distribuição demográfica da mão-de-obra médica. A relação médico/1.000 habitantes existente no Brasil evidencia essa situação: 3,28 médicos/habitantes para as capitais e 0,53 médicos/1.000 habitantes para o interior. Especificamente, observa-se que, enquanto a capital do estado de São Paulo tem 3,02 médicos/1.000 habitantes, a do Rio de Janeiro tem 4,84 e a do Espírito Santo, 6,89; as capitais dos estados do Acre, Roraima, Maranhăo e Mato Grosso apresentam, respectivamente, taxas de $0,78,0,83,1,70$ e 1,75 médicos/1.000 habitantes. Estes percentuais se mostram ainda mais díspares ao considerarmos as cidades de médio e grande porte (Campinas, Ribeirão Preto, Juiz de Fora, Campina Grande, Londrina, entre outras) como pólos catalisadores de mão-de-obra médica. Dados recentes divulgados pelo IBCE mostram que inúmeros municípios brasileiros nāo possuem sequer um médico. Para se ter uma idéia da magnitude desse problema, vale a pena observar que, dos quase 200 mil médicos existentes no País, em torno de $75 \%$ encontram-se nas regiōes Sudeste e Sul, sendo que quase $50 \%$ estão apenas em dois estados - Rio de Janeiro e São Paulo.

Os dados da Tabela 3.7 elucidam melhor essa concentração nas capitais, estratificada por tipos de estabelecimentos de saúde (privado, público e consultório).

A Tabela 3.8 aponta a existência de um mercado de trabalho com aproximadamente 350 mil postos de trabalho (setores público e privado) para um contingente de 183.052 médicos em todo o País. Além disso, como dito acima, mais de $70 \%$ desses médicos também exercem atividades em consultório, o que significa um mercado de trabalho de quase 500 mil postos de trabalho, equivalendo a 3 empregos/atividades por médico (Tabela 3.8).

Com o processo de municipalizaçāo, os empregos da esfera federal, que até a década de 80 se mantinham em destaque, vêm perdendo sua importância na composição do mercado de trabalho médico ao longo desses últimos anos. Segundo a pesquisa, nas regióes Sul e Sudeste, onde a municipalização está em processo mais avançado, os empregos públicos municipais representam $40,2 \%$ e $39,9 \%$, respectivamente.

Já no setor privado, prevalece ainda, de modo geral, a tradicional parceria com o Estado, o que representa $38,8 \%$ dos estabelecimentos privados (conveniados com o SUS e/ou INAMPS), sendo que este percentual sobe para $49,3 \%$ na região Nordeste e para $44,8 \%$ no Sul. Por outro lado, destaca-se a participação da medicina de grupo, especialmente na região Sudeste, com 12,4\% (Tabela 3.8). 


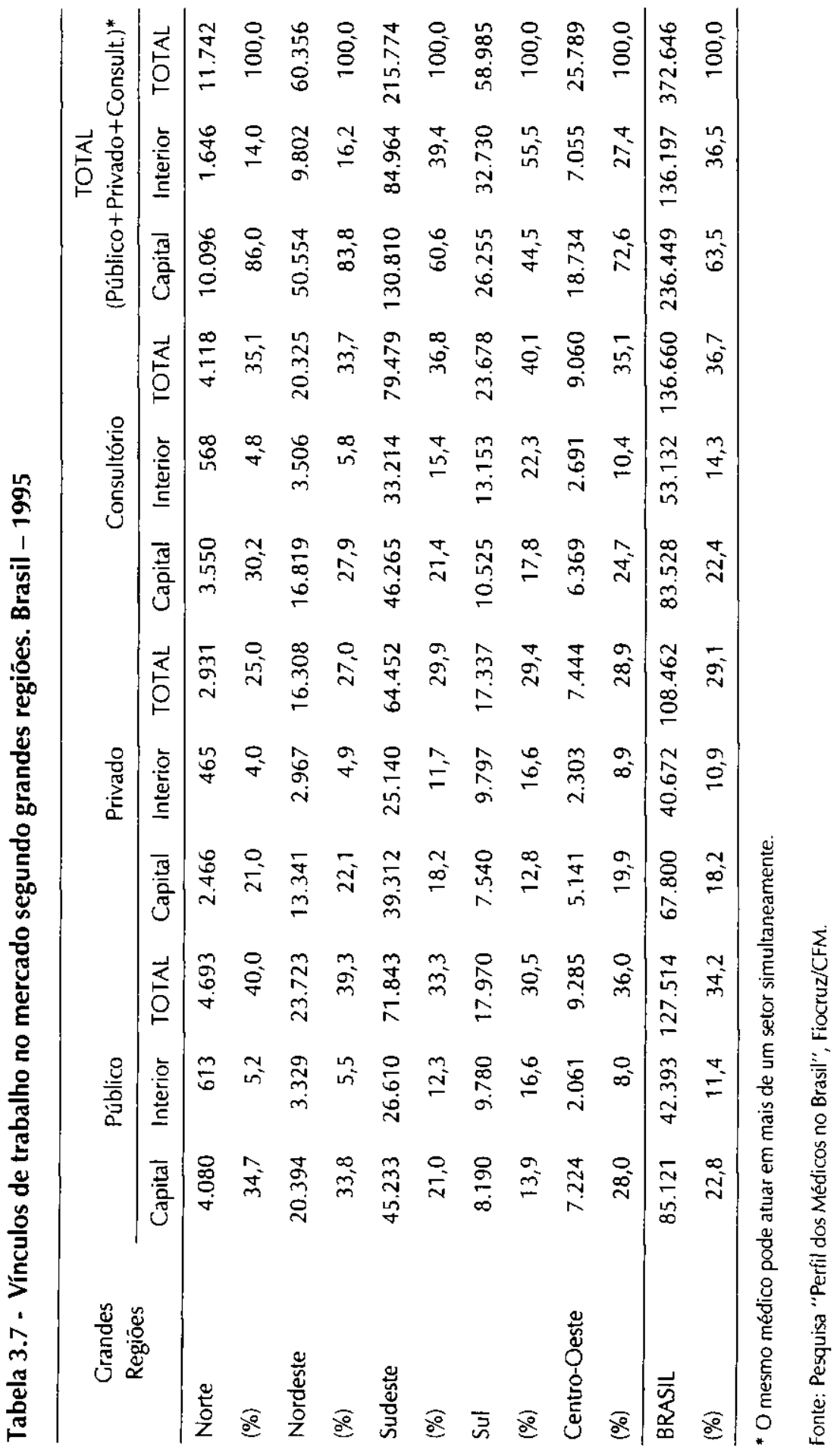




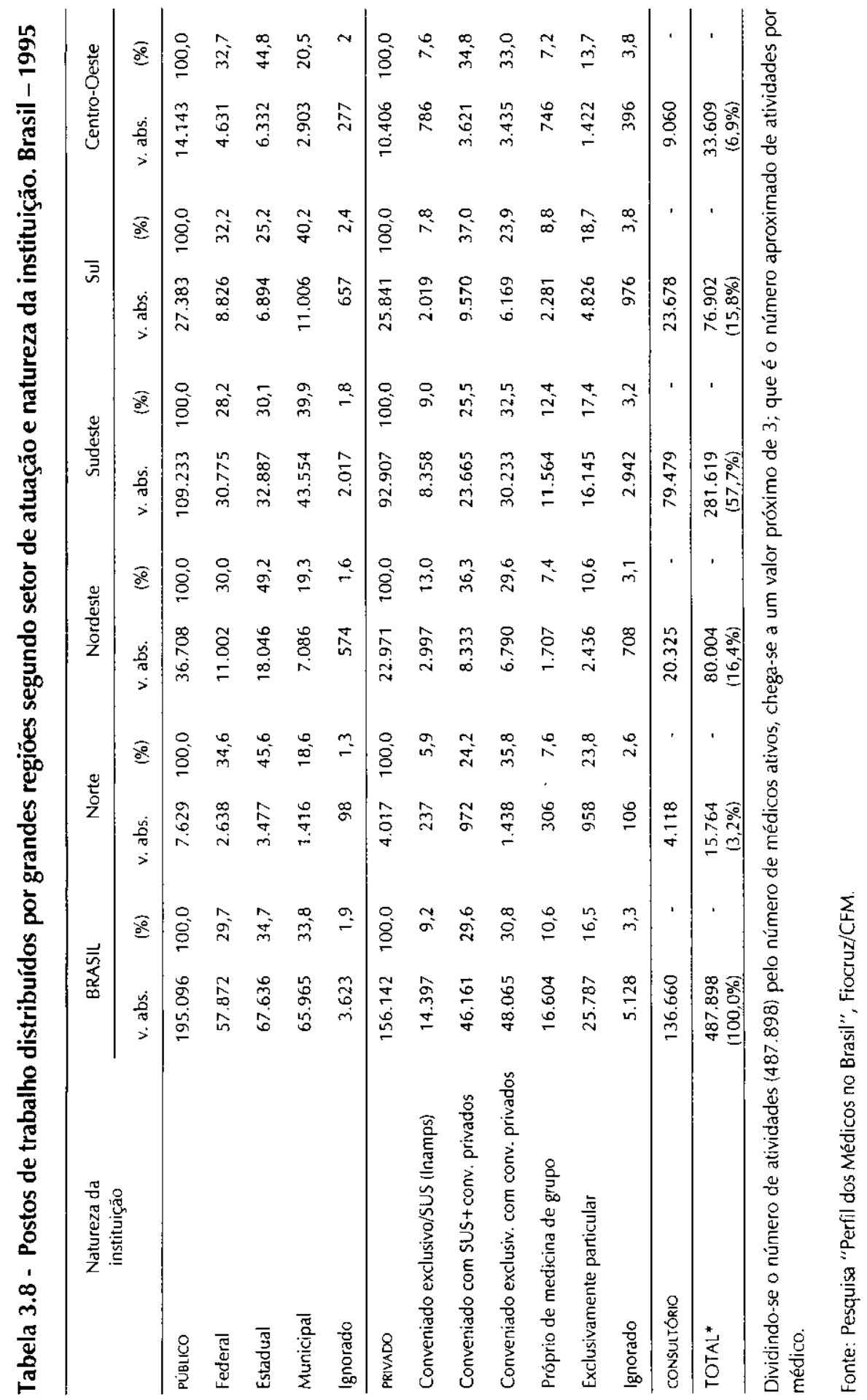


A atividade em instituições hospitalares é uma das características do trabalho médico. O hospital se destaca como lugar privilegiado de produção de senviços médicos nas esferas pública e privada (Tabela 3.9). Tanto no setor público $(46,9 \%)$ como no privado $(55,1 \%)$, os médicos encontram nas instituiçōes hospitalares seu maior empregador, situação semelhante em todas as regiōes do País. Um segundo tipo de unidade assistencial é a ambulatorial. No caso da rede privada, a polarização entre serviços hospitalares e serviços ambulatoriais é maior do que a que se apresenta na rede pública. Enquanto o setor público oferece $46,9 \%$ de sua assistência em hospitais e $12,4 \%$ em ambulatórios, a rede privada concentra $85,2 \%$ de suas atividades nessas duas modalidades assistenciais. Ressalte-se que, nas regiōes Norte e Centro-Oeste, os hospitais privados absorvem 61,4\% e $63,6 \%$, respectivamente, dos empregos médicos.

Tabela 3.9 - Médicos distribuídos por setor de atuação e grandes regiōes segundo tipo de unidade assistencial. Brasil - 1995

\begin{tabular}{|c|c|c|c|c|c|c|c|c|c|c|c|c|}
\hline \multicolumn{13}{|c|}{ Setor Público } \\
\hline \multirow{2}{*}{$\begin{array}{l}\text { Tipo de unidade } \\
\text { assistencial }\end{array}$} & \multicolumn{2}{|c|}{ BRASIL } & \multicolumn{2}{|c|}{ Norte } & \multicolumn{2}{|c|}{ Nordeste } & \multicolumn{2}{|c|}{ Sudeste } & \multicolumn{2}{|c|}{ Sul } & \multicolumn{2}{|c|}{ Centro-Oeste } \\
\hline & v. abs. & $(\%)$ & v. abs. & $(\%)$ & v. abs. & $(\%)$ & v. abs. & (\%) & v. abs. & $(\%)$ & v. abs. & $(\%)$ \\
\hline Hospital & 91.551 & 46,9 & 2.965 & 38,9 & 18.502 & 50,4 & 52.351 & 47,9 & 10.840 & 39,6 & 6.893 & 48,7 \\
\hline Posto de Saúde & 28.150 & 14,4 & 776 & 10,2 & 4.524 & 12,3 & 14.375 & 13,2 & 6.217 & 22,7 & 2.258 & 16,0 \\
\hline Ambulatório & 24.134 & 12,4 & 1.491 & 19,5 & 4.834 & 13,2 & 12.122 & 11,1 & 4.154 & 15,2 & 1.533 & 10,8 \\
\hline Centro de Saúde & 15.443 & 7,9 & 728 & 9,5 & 3.348 & 9,1 & 8.569 & 7,8 & 1.500 & 5,5 & 1.298 & 9,2 \\
\hline Pronto Socorro & 15.262 & 7,8 & 611 & 8,0 & 2.131 & 5,8 & 10.059 & 9,2 & 1.528 & 5,6 & 933 & 6,6 \\
\hline PAM & 10.208 & 5,2 & 461 & 6,0 & 1.408 & 3,8 & 6.140 & 5,6 & 1.690 & 6,2 & 509 & 3,6 \\
\hline Outros & 1.765 & 0,9 & 152 & 2,0 & 395 & 1,1 & 724 & 0,7 & 302 & 1,1 & 192 & 1,4 \\
\hline Ignorado & 8.583 & 4,4 & 445 & 5,8 & 1.566 & 4,3 & 4.893 & 4,5 & 1.152 & 4,2 & 527 & 3,7 \\
\hline TOTAL & 195.096 & 100,0 & 7.629 & 100,0 & 36.708 & 100,0 & 109.233 & 100,0 & 27.383 & 100,0 & 14.143 & 100,0 \\
\hline \multicolumn{13}{|c|}{ Setor Privado } \\
\hline \multirow{2}{*}{$\begin{array}{l}\text { Tipo de unidade } \\
\text { assistencial }\end{array}$} & \multicolumn{2}{|c|}{ BRASIL } & \multicolumn{2}{|c|}{ Norte } & \multicolumn{2}{|c|}{ Nordeste } & \multicolumn{2}{|c|}{ Sudeste } & \multicolumn{2}{|c|}{ Sul } & \multicolumn{2}{|c|}{ Centro-Oeste } \\
\hline & v. abs. & $(\%)$ & v. abs. & (\%) & v. abs. & $(\%)$ & v. abs. & $(\%)$ & v. abs. & (\%) & v. abs. & $(\%)$ \\
\hline Hospital & 86.093 & 55,1 & 2.465 & 61,4 & 12.806 & 55,7 & 50.935 & 54,8 & 13.272 & 51,4 & 6.615 & 63,6 \\
\hline Posto de Saúde & 2.019 & 1,3 & 19 & 0,5 & 342 & 1,5 & 851 & 0,9 & 637 & 2,5 & 170 & 1,6 \\
\hline Ambulatório & 46.995 & 30,1 & 1.069 & 26,6 & 6.707 & 29,2 & 29.292 & 31,5 & 7.611 & 29,5 & 2.316 & 22,3 \\
\hline Centro de Saúde & 2.859 & 1,8 & 55 & 1,4 & 460 & 2,0 & 1.619 & 1,7 & 568 & 2,2 & 157 & 1,5 \\
\hline Pronto Socorro & 5.558 & 3,6 & 140 & 3,5 & 1.103 & 4,8 & 2.564 & 2,8 & 1.430 & 5,5 & 321 & 3,1 \\
\hline PAM & 1.408 & 0,9 & 29 & 0,7 & 221 & 1,0 & 708 & 0,8 & 375 & 1,5 & 75 & 0,7 \\
\hline Outros & 792 & 0,5 & 0 & 0,0 & 150 & 0,7 & 507 & 0,5 & 82 & 0,5 & 53 & 0,5 \\
\hline Ignorado & 10.418 & 6,7 & 240 & 6,0 & 1.182 & 5,1 & 6.431 & 6,9 & 1.866 & 7,2 & 699 & 6,7 \\
\hline TOTAL & 156.142 & 100,0 & 4.017 & 100,0 & 22.971 & 100,0 & 92.907 & 100,0 & 25.841 & 100,0 & 10.406 & 100,0 \\
\hline
\end{tabular}

Fonte: Pesquisa "Perfil dos Médicos no Brasil", Fiocruz/CFM. 
Tradicionalmente, costuma-se associar a atividade liberal exercida pelo médico à sua atuação em consultório particular. No entanto, as evidências empíricas não nos autorizam a afirmar que o médico que atua no Brasil hoje desenvolve essa típica atividade liberal. Como veremos no próximo capítulo, a sensível deterioração econômica dos 'compradores individuais e por conta própria' de serviços médicos tem levado muitos profissionais a firmar convênios de diversas modalidades e, até mesmo, a se associar à medicina de grupo, como alternativa para manter seus consultórios em funcionamento.

Apenas 36,5\% dos médicos exercem suas atividades em consultório - alugado ou próprio - de forma individual (Tabela 3.10). Isso significa que a maioria absoluta o faz mediante a divisão dos gastos mensais para a manutenção desse estabelecimento. ${ }^{6}$ São significativos os percentuais apresentados para os que exercem essa atividade inseridos em estabelecimentos de saúde - comodato em hospitais $(6,8 \%)$-, .os que cedem parte de sua produção $(6 \%)$ e os que sublocam horário $(3,8 \%)$, totalizando $16,6 \%$.

Tabela 3.10 - Médicos distribuídos por modalidade de consultório segundo grandes regiōes. Brasil - 1995

\begin{tabular}{|c|c|c|c|c|c|c|c|c|c|c|c|c|}
\hline \multirow{2}{*}{$\begin{array}{c}\text { Modalidade } \\
\text { de consultório }\end{array}$} & \multicolumn{2}{|c|}{ BRASIL } & \multicolumn{2}{|c|}{ Norte } & \multicolumn{2}{|c|}{ Nordeste } & \multicolumn{2}{|c|}{ Sudeste } & \multicolumn{2}{|c|}{ Sul } & \multicolumn{2}{|c|}{$\begin{array}{l}\text { Centro- } \\
\text { Oeste }\end{array}$} \\
\hline & v. abs. & $(\%)$ & v. abs. & (\%) & v. abs. & (\%) & v. abs. & (\%) & v. abs. & (\%) & v. abs. & $(\%)$ \\
\hline Próprio & 55.425 & 40,5 & 1.807 & 43,9 & 8.399 & 41,4 & 30409 & 38,3 & 11.015 & 46,5 & 3.795 & 41,9 \\
\hline Individual & 36.499 & 26,7 & 1.337 & 32,5 & 5.316 & 26,2 & 19.457 & 24,5 & 7.990 & 33,7 & 2.399 & 26,5 \\
\hline Em grupo & 18.926 & 13,8 & 470 & 11,4 & 3.083 & 15,2 & 10.952 & 13,8 & 3.025 & 12,8 & 1.396 & 15,4 \\
\hline Alugado & 41.127 & 30,1 & 981 & 23,8 & 5.302 & 26,1 & 25.701 & 32,3 & 7.221 & 30,5 & 1.922 & 21,2 \\
\hline Individual & 13.435 & 9,8 & 370 & 9,0 & 1.844 & 9,1 & 7862 & 9,9 & 2.636 & 11,1 & 723 & 8,0 \\
\hline Em grupo & 27.692 & 20,3 & 611 & 14,8 & 3.458 & 17,0 & 17.839 & 22,4 & 4.585 & 19,4 & 1.199 & 13,2 \\
\hline Comodato em ho & 9.255 & 6,8 & 397 & 9,6 & 1.509 & 7,4 & 4.136 & 5,2 & 1.798 & 7,6 & 1.415 & 15,6 \\
\hline $\begin{array}{l}\text { Cedendo percentual } \\
\text { de sua produção }\end{array}$ & רו17 & 6,0 & 207 & 5,0 & 1.933 & 9,5 & 4.816 & 6,1 & 707 & 3,0 & 549 & 6,1 \\
\hline Horário sublocado & 5.260 & 3,8 & 171 & 4,2 & 651 & 3,2 & 3.690 & 4,6 & 524 & 2,2 & 224 & 2,5 \\
\hline Outras & 5.640 & 4,1 & 138 & 3,4 & 998 & 4,9 & 3.207 & 4,0 & 878 & 3,7 & 419 & 4,6 \\
\hline Ignorado & 11.741 & 8,6 & 417 & 10,1 & 1.533 & 7,5 & 7.520 & 9,5 & 1.535 & 6,5 & 736 & 8,1 \\
\hline TOTAL & 136.660 & 100,0 & 4.118 & 100,0 & 20.325 & 100,0 & 79.479 & 100,0 & 23.678 & 100,0 & 9.060 & 100,0 \\
\hline
\end{tabular}

Fonte: Pesquisa "Perfil dos Médicos no Brasil", Fiocruz/CFM.

6 De acordo com estudos realizados pela Fundação Instituto de Pesquisas Económicas - FIPE, o custo mensal de um consultório padrão no estado de São Paulo é de R\$ 5.157,62. Para mais detalhes, ver artigo "Uma solução civilizada". Jornal do Conselho Federal de Medicina, dez.96. 


\section{DINÂMICA DO MERCADO DE TRABALHO}

\section{A INSERÇĀO DO MÉDICO NO MUNDO DO TRABALHO}

A discussão sobre a situação do mercado de trabalho médico no Brasil não é nova. Diversos estudos já realizados, embora de caráter mais quantitativo ou mais restrito, tiveram e têm grande importância para a compreensão deste complexo campo. Considerando os fins desta publicação, não se considerou pertinente proceder a uma ampla revisão dessas pesquisas, entretanto, cabe fazer referência a algumas delas.

Estudos desenvolvidos por Sayeg, Paim, Nogueira, Médici, Machado e Girardi, especialmente na década de 80 , utilizando as bases de dados do IBCE, desvendaram as tendências macro desse mercado, como o assalariamento, o prolongamento da jornada de trabalho, o multiemprego e a feminilização, entre outras. Já as pesquisas realizadas por Donnangelo nos anos 70, em Săo Paulo, e, posteriormente, por Machado na década de 80 , em Belo Horizonte, possibilitaram um enfoque mais específico, demonstrando as múltiplas formas de inserções e já assinalando a atuação das empresas de medicina de grupo.

Poucos são os autores brasileiros que, ao longo das últimas décadas, se dedicaram à tarefa de traçar e discutir políticas de recursos humanos para o setor saúde. São análises que privilegiaram o enfoque quantitativo, uma vez que a inexistência de conhecimento analítico dos dados disponíveis levou esses autores a assumir a árdua tarefa de desvendar o universo de trabalhadores que constitui o setor de prestação de serviços de saúde no Brasil.

$\mathrm{Na}$ década de 90, destacam-se os estudos de natureza sociológica, que incorporam os referenciais da sociologia das profissōes às análises de mercado, consubstanciando-se em nova abordagem. Além de inúmeros trabalhos de Machado, diversos trabalhos foram realizados nesta perspectiva analítica: Santos Neto (1993), sobre o processo de profissionalização dos médicos pernambucanos; Belisário (1993), so- 
bre os médicos sanitaristas; Santos (1993), sobre os farmacêuticos; Falcão (1993), sobre os médicos e a ética profissional; Schraiber (1989, 1993), Rego (1994), Ribeiro (1995), sobre formação profissional e autonomia médica; Pereira Neto (1997), sobre o movimento médico numa perspectiva histórica, entre outros. As análises aqui empreendidas incorporaram esses referenciais, embora, pela abrangência e escopo desta publicação, não tenha sido possível desenvolver teoricamente cada um desses aspectos. Menção especial deve-se à obra de Santos FiIho, que, durante décadas, vem se dedicando a fazer a memória da profissão médica no Brasil. Tais estudos representam uma das raras e valiosas contribuições para compreender a história da medicina em nosso país.

No entanto, poucos foram os estudos realizados com dados empíricos de pesquisa de mercado de trabalho que buscaram entender as diversas formas de inserção do médico no mundo do trabalho no Brasil. A pesquisa "Perfil dos Médicos no Brasil" representa o primeiro esforço, a partir de um trabalho de campo, para compreender a situação desse contingente profissional. É exatamente com esta base de dados que passaremos a analisar as formas como se dá a prestação de serviços médicos no sistema de saúde brasileiro.

Neste capítulo, examinaremos a inserção dos médicos no mundo do trabalho tomando como ponto de partida a idéia de que a atividade e o processo de trabatho médicos são, por natureza, múltiplos. Em outras palavras, a vida profissional do médico é constituída de inúmeras passagens em instituições de saúde, hospitais, alteração na hierarquia da equipe médica (de aprendiz da medicina - médico-residente - a preceptor - mestre do ofício), mudanças de área de atuação, com alteração, por vezes radical, de especialização ou até mesmo migração de cidade ou de estado. A medicina, como poucas profissóes, permite essa dinâmica especial de 'estar no mundo do trabalho'.

Trata-se de um contingente que foi socializado para ter esse padrão de vida profissional, que teve a mentalidade forjada no pressuposto da liberdade de ir e vir, liberdade de escolha institucional para exercer seu ofício e, especialmente, no da autonomia de decisão no pensar e fazer seu cotidiano profissional. Portanto, a múltipla inserção do médico no mundo do trabalho não é, como parece ao senso comum, uma disfunção do mercado, resultado de uma crise econômica, mas conseqüência esperada de seu processo de trabalho. A idéia de atividade ou emprego único (mesmo que no consultório particular) não é uma premissa sociológica da mentalidade médica típica. Esse modelo de carreira numa só organização é, na verdade, uma moldura conceitual de vida profissional compatível com carreiras de vocação técnico-burocrática, que pressupōem um processo evolutivo no interior da estrutura organizacional em que se inserem. É o caso, por exemplo, de professores universitários, economistas, administradores, advogados, intelectuais, técnicos governamentais e, até mesmo, de alguns poucos segmentos médicos que se dedicam à burocracia, como os médicos-sanitaristas e os administradores hospitalares, entre outros. 
Antes de passar à discussão dos dados referentes a essa questão, é pertinente registrar que a posição teórica que adotamos para analisar o mundo de trabalho médico não exclui o pressuposto de que as instituições de saúde, públicas ou privadas, que contratam os serviços médicos necessitam ter políticas adequadas para que o médico e demais profissionais da saúde desenvolvam seu trabalho e vislumbrem um processo evolutivo na carreira profissional.

\section{A CONFORMAÇÃO DO MERCADO DE TRABALHO MÉDICO}

Constituindo um mercado de trabalho com mais de duzentos mil profissionais, que atuam em quase cinqüenta mil estabelecimentos de saúde (hospitalares $\mathrm{e}$ ambulatoriais) e prestam assistência médica a mais de quinhentos mil leitos, os médicos representam, no setor de serviços essenciais à sociedade, o segmento profissional mais dinâmico e que responde pela maioria dos empregos e prestação direta de serviços num sistema constituído de uma sólida rede pública e privada.

Do total de médicos no Brasil, $92,6 \%$ são ativos e $4,4 \%$ aposentados, havendo uma taxa de $2,0 \%$ que abandonaram e/ou se afastaram do exercício da profissão. Essa forte adesão ao projeto profissional é reforçada quando se percebe que tal proporção de ativos năo oscila muito em funçăo da região. A Sudeste tem a maior participação de médicos aposentados (4,9\%), em especial o estado do Rio de Janeiro, com $8,4 \%$.

Tabela 4.1 - Médicos distribuídos por grandes regiōes segundo situação profissional declarada. Brasil - 1995

\begin{tabular}{|c|c|c|c|c|c|c|c|c|c|c|c|c|}
\hline \multirow{2}{*}{$\begin{array}{l}\text { Situação } \\
\text { Profissional }\end{array}$} & \multicolumn{2}{|c|}{ BRASIL. } & \multicolumn{2}{|c|}{ Norte } & \multicolumn{2}{|c|}{ Nordeste } & \multicolumn{2}{|c|}{ Sudeste } & \multicolumn{2}{|c|}{ Sul } & \multicolumn{2}{|c|}{ Centro-Oeste } \\
\hline & v. abs. & $(\%)$ & v. abs. & (\%) & v. abs. & $(\%)$ & v. abs. & (\%) & v. abs. & $(\%)$ & v. abs. & (\%) \\
\hline Ativo & 169.415 & 92,6 & 5.361 & 94,1 & 26.997 & 92,3 & 98.993 & 92,0 & 26.506 & 94,3 & 11.558 & 93,0 \\
\hline Apose & 7.991 & 4,4 & 189 & 3,3 & 1.257 & 4,3 & 5.255 & 4,9 & 747 & 2,7 & 543 & 4,4 \\
\hline Afas & 3.026 & 1,7 & 127 & 22 & 558 & 1,9 & 1.706 & 1,6 & 438 & 1,6 & 197 & 1,6 \\
\hline Deser & 567 & 0,3 & 2 & 0,0 & 145 & 0 & 314 & 0 . & 94 & 0,3 & 12 & 0,1 \\
\hline Aba & 509 & 0,3 & 0 & 0,0 & 118 & 0,4 & 295 & 0,3 & 72 & 0,3 & 24 & 0,2 \\
\hline Ignora & 1.344 & 0,8 & 19 & 0,3 & 174 & 0,6 & 1.002 & 0,9 & 251 & 0,9 & 98 & 0,8 \\
\hline OTAL & 83.052 & 100,0 & 5.698 & 100,0 & 29.249 & 100,0 & 107.565 & 100,0 & 28.108 & 100,0 & 12.432 & 100,0 \\
\hline
\end{tabular}

* Inclui os médicos ativos/aposentados, ou seja, aqueles que estão ativos em uma atividade e aposentados em outra. Alguns médicos, apesar de se declararem aposentados, exercem eventualmente atividade em consultório.

Fonte: Pesquisa "Perfil dos Médicos no Brasil", Fiocruz/CFM. 
A distribuiçăo do contingente de profissionais em atividade, apresentada no capítulo 1, irá refletir-se na dinâmica do mercado de trabalho brasileiro, que tem alta concentração de médicos atuando nas regiões mais desenvolvidas (Sudeste e Sul). Estes médicos acabam elevando a renda média nacional por meio do multiemprego ou mesmo dos empresários da saúde.

O contingente médico é constituído majoritariamente de pediatras, gineco-obstetras, clínicos, cirurgiões-gerais e anestesistas, o que equivale a 80.513 $44 \%$ - de um total de 183.052 médicos em todo o País (Quadro 4.4). Além disso, diversas especialidades são típicas das regiões Sul e Sudeste, principalmente as que requerem alto domínio técnico-científico, tanto do saber quanto da prática profissional (cirurgia cardiovascular, genética clínica, neurocirurgia, terapia intensiva, hemoterapia, entre outras).

Mudanças estruturais no mundo do trabalho provocaram redefiniçōes nas formas do trabalho médico. Variáveis que antes não eram cruciais para a análise de mercado, como, por exemplo, gênero e idade, passaram a explicar algumas importantes mudanças estruturais que estão ocorrendo no mercado de serviços médicos. No capítulo 5, abordaremos em especial a questâo do gênero como determinante dessas mudanças. É fundamental destacar aqui que, embora esse mercado seja constituído majoritariamente de homens, as mulheres têm sido capazes de reverter, em pouco tempo, essa hegemonia masculina.

Como relatado no capítulo 1, a medicina no Brasil é exercida por jovens, com menos de 15 anos de inserção no mercado de trabalho. Associado ao fenômeno da 'feminilização', esse processo de 'rejuvenescimento' do contingente médico traz à tona questỏes sócio-econômicas que antes receberam pouca atenção das autoridades que formulam políticas de recursos humanos. Como se verá mais adiante, esse contingente jovem e tendencialmente feminino vai requerer novas definições e novas inserções no mercado de trabalho, compatíveis com suas necessidades e perspectivas de 'estar no mundo do trabalho'.

Uma das características mais marcantes do trabalho médico é a intensidade do processo de trabalho, ou seja, em geral esses profissionais têm jornadas longas e exercem atividades simultâneas em diversos locais. A pesquisa revelou que os médicos, em geral, desenvolvem diferentes atividades ao mesmo tempo: $54,7 \%$ conciliam três ou mais. Esse fato ocorre, com destaque, nas regiōes Nordeste $(58,8 \%)$, Norte $(58,6 \%)$ e Sul $(58,5 \%)$ (Tabela 4.2$)$. 
Tabela 4.2 - Médicos distribuídos por número de atividades segundo grandes regiöes.* Brasil - 1995

\begin{tabular}{|c|c|c|c|c|c|c|c|c|}
\hline \multirow{2}{*}{\multicolumn{2}{|c|}{$\begin{array}{c}\text { Brasil e Grandes } \\
\text { Regiōes }\end{array}$}} & \multicolumn{7}{|c|}{ Número de atividades** } \\
\hline & & \multirow{2}{*}{$\frac{\text { Uma }}{850}$} & \multirow{2}{*}{$\begin{array}{l}\text { Duas } \\
1.464\end{array}$} & \multirow{2}{*}{$\begin{array}{l}\text { Três } \\
1.673\end{array}$} & \multirow{2}{*}{$\frac{\text { Quatro }}{1.111}$} & \multirow{2}{*}{$\frac{\text { Cinco }}{416}$} & \multirow{2}{*}{$\begin{array}{c}\begin{array}{c}\text { Mais de } \\
\text { cinco }\end{array} \\
71\end{array}$} & \multirow{2}{*}{$\begin{array}{r}\text { TOTAL } \\
5.585\end{array}$} \\
\hline Norte & v. abs. & & & & & & & \\
\hline & $(\%)$ & 15,2 & 26,2 & 30,0 & 19,9 & 7,4 & 1,3 & 100,0 \\
\hline \multirow[t]{2}{*}{ Nordeste } & v. abs. & 4.442 & 7.251 & 9.292 & 4.831 & 1.808 & 774 & 28. \\
\hline & $(\%)$ & 15,6 & 25,5 & 32,7 & 17,0 & 6,4 & 2,7 & 100,0 \\
\hline \multirow[t]{2}{*}{ Sudeste } & v. abs. & 18.245 & 31.735 & 30.590 & 15.855 & 6.198 & 2.158 & 104.781 \\
\hline & (\%) & 17,4 & 30,3 & 29,2 & 15,1 & 5,9 & 2,1 & 100,0 \\
\hline \multirow[t]{2}{*}{ Sul } & v. abs. & 5.188 & 6.242 & 9.033 & 4.535 & 1.569 & 964 & 27.531 \\
\hline & $(\%)$ & 18,8 & 22,7 & 32,8 & 16,5 & 5,7 & 3,5 & 100,0 \\
\hline \multirow[t]{2}{*}{ Centro-Oeste } & v. abs. & 2.390 & 3.063 & 3.432 & 2.069 & 875 & 329 & 12.158 \\
\hline & (\%) & 19,7 & 25,2 & 28,2 & 17,0 & 7,2 & 2,7 & 100,0 \\
\hline \multirow[t]{2}{*}{ BRASIL } & v. abs. & 31.115 & 49.755 & 54.020 & 28.401 & 10.866 & 4.296 & 178.453 \\
\hline & (\%) & 17,4 & 27,9 & 30,3 & 15,9 & 6,1 & 2,4 & 100,0 \\
\hline
\end{tabular}

* A diferença observada em relação ao total geral de médicos refere-se a médicos aposentados, afastados e desempregados e aqueles que não declararam.

** Atividades $\approx$ público + privado + consultório.

Fonte: Pesquisa "Perfil dos Médicos no Brasil", Fiocruz/CFM.

Constata-se também que o Distrito Federal tem o maior índice de médicos com até duas atividades $(57,5 \%)$, seguido pelos estados do Pará $(53,2 \%)$ e Rio de Janeiro $(53,0 \%)$. Paralelamente, estes estados apresentam os índices mais baixos de médicos com quatro ou mais atividades. Chama a atenção o fato de os estados que compõem a regiáo Norte - exceto o Pará, cuja maioria dos profissionais atua em apenas duas atividades - apresentarem os maiores índices de médicos com múltiplos vínculos, demonstrando uma sobrecarga de trabalho para aqueles que atuam nessa região: Roraima (47,5\%), Amapá $(38,9 \%)$, Rondônia $(38,1 \%)$. A escassez de profissionais e a baixa densidade populacional explicam, em parte, essa situação peculiar que obriga o médico a atuar em vários municípios e estabelecimentos para suprir a deficiência do sistema de saúde regional. Por outro lado, como mostrado acima, é de peculiar interesse para a formulação de políticas de recursos humanos observar que, exatamente nas Unidades da Federação - Rio de Janeiro, Pará e Distrito Federal - onde os médicos declaram ter menor acumulação de atividades (multiemprego), o índice de desgaste físico e mental se apresenta com sensivel diferença em relação aos demais estados brasileiros. A associação de um emprego (público, quase sempre) à atividade em consultório pa- 
Tabela 4.3 - Médicos distribuídos por número de atividades segundo Unidades da Federação. Brasil - 1995

\begin{tabular}{|c|c|c|c|c|}
\hline \multirow{2}{*}{$\begin{array}{c}\text { Unidades } \\
\text { da Federação }\end{array}$} & \multicolumn{4}{|c|}{ Número de atividades (\%) } \\
\hline & até duas & três & mais de três & TOTAL \\
\hline REGIÃO NORTE & 41,4 & 30,0 & 28,6 & 100,0 \\
\hline Acre & 31,4 & 33,3 & 35,3 & 100,0 \\
\hline Amapá & 28,5 & 32,5 & 38,9 & 100,0 \\
\hline Amazonas & 33,1 & 30,1 & 36,8 & 100,0 \\
\hline Pará & 53,2 & 30,5 & 16,2 & 100,0 \\
\hline Rondônia & 32,9 & 28,9 & 38,1 & 100,0 \\
\hline Roraima & 31,9 & 20,6 & 47,5 & 100,0 \\
\hline Tocantins & 32,6 & 36,4 & 31,0 & 100,0 \\
\hline REGIÄO NORDESTE & 41,1 & 32,7 & 26,1 & 100,0 \\
\hline Alagoas & 43,5 & 29,1 & 27,4 & 100,0 \\
\hline Bahia & 38,5 & 33,9 & 27,7 & 100,0 \\
\hline Ceará & 37,6 & 35,2 & 27,2 & 100,0 \\
\hline Maranhão & 43,0 & 30,7 & 26,2 & 100,0 \\
\hline Paraíba & 43,9 & 33,5 & 22,7 & 100,0 \\
\hline Pernambuco & 46,5 & 32,6 & 20,8 & 100,0 \\
\hline Piauí & 34,9 & 28,5 & 36,6 & 100,0 \\
\hline Rio Grande do Norte & 43,1 & 29,9 & 27,0 & 100,0 \\
\hline Sergipe & 36,1 & 32,6 & 31,3 & 100,0 \\
\hline REGIĀO SUDESTE & 47,7 & 29,2 & 23,1 & 100,0 \\
\hline Espírito Santo & 36,9 & 32,2 & 30,8 & 100,0 \\
\hline Minas Gerais & 40,7 & 30,8 & 28,6 & 100,0 \\
\hline Rio de Janeiro & 53,0 & 27,5 & 19,5 & 100,0 \\
\hline São Paulo & 48,3 & 29,2 & 22,5 & 100,0 \\
\hline REGIĀO SUL & 41,5 & 32,8 & 25,7 & 100,0 \\
\hline Paraná & 39,9 & 28,5 & 31,7 & 100,0 \\
\hline Rio Grande do Sul & 44,6 & 35,4 & 19,8 & 100,0 \\
\hline Santa Catarina & 34,3 & 32,7 & 33,0 & 100,0 \\
\hline REGIÄO CENTRO-OESTE & 44,9 & 28,2 & 26,9 & 100,0 \\
\hline Distrito Federal & 57,5 & 25,7 & 16,8 & 100,0 \\
\hline Goiás & 37,1 & 30,0 & 32,8 & 100,0 \\
\hline Mato Grosso & 36,7 & 28,4 & 34,9 & 100,0 \\
\hline Mato Grosso do Sul & 37,6 & 30,4 & 31,9 & 100,0 \\
\hline BRASIL & 45,3 & 30,3 & 24,4 & 100,0 \\
\hline
\end{tabular}

Fonte: Pesquisa "Perfil dos Médicos no Brasil", Fiocruz/CFM. 
rece ser a forma mais adequada para manter os médicos em 'plena forma', com índices de desgaste e estresse compativeis com a intensidade e a natureza do trabalho médico. Tais questões serão aprofundadas no capítulo 6 , que apresenta, de forma detalhada, as condiçōes de vida e de trabalho dos médicos em geral.

No que se refere à renda mensal declarada dos médicos, a pesquisa năo registra diferenças salariais entre as regióes ou estados, como se pode observar no Gráfico 4.1. No entanto, as disparidades salariais vão se dar ao analisarmos o rendimento do médico e sua escolha profissional, ou seja, em que especialidade ele atua e o fato de ser ou não 'novato' no mercado de trabaIho (Quadro 4.5 e 4.6). O gênero também é uma variável de grande valor explicativo para as disparidades salariais. Ser mulher, quase sempre 'novata' no mercado, e atuar em determinada especialidade, freqüentemente de baixo prestígio sócio-econômico, significam, em grande número de casos, condiçōes desfavoráveis no mercado, com jornadas menores e salários mais baixos, configurando um segmento diferenciado de médicos. Estas e outras questões afins serão dicutidas posteriormente.

\section{Gráfico 4.1 - Médicos distribuídos por grandes regiōes segundo renda mensal declarada.* Brasil - 1995}

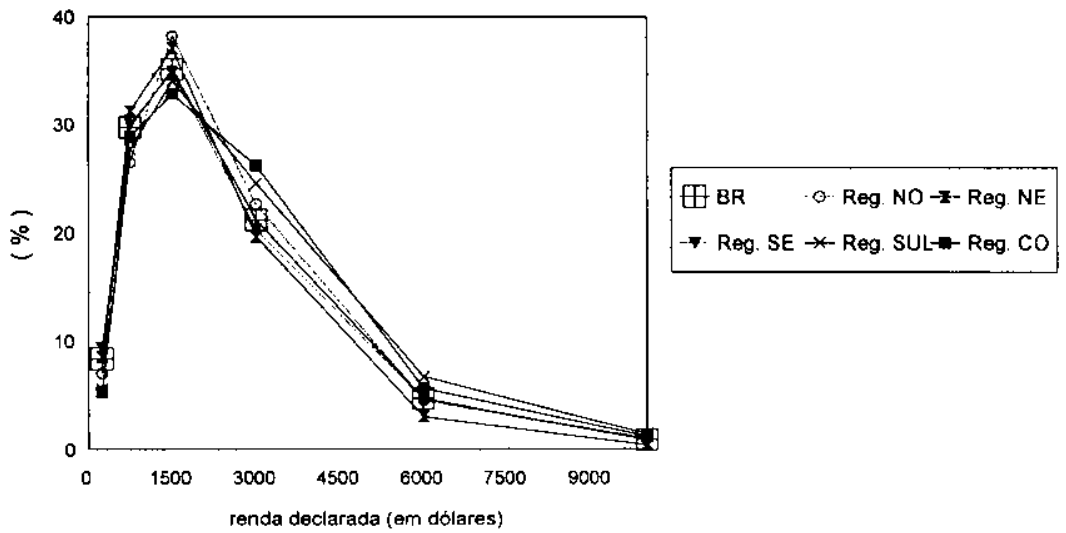

* A renda mensal dectarada corresponde à obtida com o trabalho médico. Os valores modais foram de $1.429,8$ para a região Norte; $1.250,3$, Nordeste; $1.252,1$, Sudeste; $1.400,6$, Sul e 1.371.1, Centro-Oeste.

Fonte: Pesquisa "Perfil dos Médicos no Brasil", Fiocruz/CFM. 


\section{AS TIPOLOGIAS DE MERCADO}

Ao analisar as formas de inserção do médico no mercado de trabatho, deparamo-nos com a dificuldade metodológica de realizar uma análise sócio-econômica detalhada, pelo fato de se tratar de um mercado de prestação de serviços complexo e de difícil compreensão. Poucos são os médicos que adotam ou podem adotar 'formas puras' de exercer seu ofício. Como abordamos no início deste capítulo, os médicos, pela natureza de sua atividade e do processo de trabalho, têm uma forma singular de estar no mundo de trabalho. As análises de mercado empreendidas nas décadas de 70 e 80 , tomando emprestadas as categorias macro e micro da economia (Donnangelo, Médici, Nogueira, Machado e Girardi, entre outros), não foram sensíveis o bastante para captar as dimensōes explicativas que compreendam, efetivamente, esse universo. Portanto, no mundo do trabalho médico, é praticamente impossível propor análises de tipos puros (assalariado ou liberal). Essas dimensões, até então tidas como forças explicativas, não resistiriam a uma investigação mais rigorosa, com base, por exemplo, na economia política ou na sociologia econômica.

Um bom exemplo de tal 'incapacidade analítica' amparada nessa vetha moldura conceitual é o estudo em que Campos (1988) - utilizando definições originais de Donnangelo, reinterpretadas por Cohn \& Donnangelo (1982:65-67) - descreve as formas de inserção dos médicos no mercado, a saber:

a) trabalho liberal, caracterizado por apresentar

a existência de clientela própria, canalizada através de processos informais, com a qual estabelece as condições de remuneração (...) e a posse, pelo médico, dos instrumentos de trabalho, ai incluídos o aluguel de equipamentos;

b) assalariamento, definido como

categoria que engloba os médicos que vendem sua força de trabalho, por tempo determinado, em troca de salário;

c) proprietários, sendo aqueles que

detêm o controle de condições materiais de trabalho ampliadas em relaçāo aos instrumentos que podem ser operados por um único ou por poucos profissionais;

d) autônomos

poderiam ser considerados intermediários ou transacionais entre o liberal e o assalariado, na medida em que envolvem um controle parcial dos meios de trabalho ou da clientela. (...) a categoria dos autônomos compreende médicos cujas formas de relacionamento com a clientela e com as instituiçōes médicas não são idênticas. (...) Essa diferenciação interna à categoria acarreta, naturalmente, uma certa imprecisão, aproximando-a alternativamente do trabalho liberal e do trabalho assalariado e colocando-a na condição de categoria residual por referência às demais. 
Apesar de Campos, apropriadamente, refutar a conotação de 'residual' conferida ao 'autônomo', ele a atribui aos 'liberais' e confere, no entanto, aos autônomos o caráter de "forma possível de organizaçăo da pequena produção de serviços de saúde" num contexto econômico marcado pela interferência do Estado, do capital financeiro e da indústria. Assim, esse autor considera tal forma de inserção no mercado como complementar ao assalariamento, apontando uma preferência dos médicos por esta modalidade como uma "busca de defesa de seus níveis de renda e ampliação das oportunidades de emprego" (Campos, 1988:35).

Embora reconheçamos a adesão dos médicos a esta modalidade, devemos ser menos generosos nas concessōes ao senso comum. A expressăo 'médico autôno$\mathrm{mo}^{\prime}$, da forma como é utilizada por esse autor, está associada à modalidade de inscrição do profissional na Previdência Social e nas Secretarias de Fazenda e, sem dúvida, representa uma expressão habitualmente utilizada pelos médicos para referirse à sua condiçăo de 'não-empregado'. Uma análise sociológica não deve limitar-se a questōes hermenêuticas, nem se apoiar em eufemismos ideológicos, mas, sim, desmistificar o que for necessário.

Vejamos, portanto, quem são os autônomos descritos por Campos, já que ele excluiu os 'liberais', embora estes possuam o mesmo tipo de registro na Previdência Social. São "o(s) médico(s) credenciado(s) pelo Inamps, para atender previdenciários em seu(s) consultório(s)", 1 os "médicos filiados às UNIMEDs (....); os que trabalham conveniados com a indústria, o comércio ou com seguradoras privadas" (Campos, 1988:32). Ora, é sobre os que atuam, em seus consultórios ou clínicas, no sistema baseado no pré-pagamento (subordinados a terceiros), público ou privado, que este sistema mais interfere, limitando esses profissionais em sua autonomia técnica e econômica.

Em estudo recente, Machado (1996) assinala que os médicos 'liberais', em seus consultórios dependentes de convênios, com forte vocação racionalizadora, têm a autonomia médica tolhida em vários aspectos. Tais limitaçōes abrangem desde a determinaçăo do retorno do paciente ao consultório para acompanhamento da enfermidade, até a escolha de procedimentos terapêuticos e diagnósticos, e, mais fortemente, a determinação do valor de seus serviços, o que o obriga a trabalhar a preço de 'atacado' e a prestar assistência na qualidade de 'varejo'. Estes médicos, destituídos de liberdade profissional, devem ser (in)justamente chamados de autônomos? Certamente que nāo. Eles exercem sua profissão como liberais, embora sejam cerceados nesta prática. Entre os 'liberais' que trabalham sem vinculação ao sistema de pré-pagamento, convivem os que fizeram esta escolha (em geral, quando possuem uma clientela ampla e diversificada, estando já consolidados no mercado) com os que não tiveram opção, pois são os convênios que năo os aceitam (especialidades como psiquiatria, infectologia, homeopatia e acupuntura, por exemplo).

1 Adaptando-se a definição ao nosso tempo, refere-se aos credenciados pelo SUS. 
Estes últimos, por tratarem de patologias de longa duração e com características que as tornam antieconômicas para as empresas.

A partir dessa nova ordem de problemas, adotamos o recurso da sociologia de 'tipificar' realidades e, a partir daí, flexibilizar a análise das mesmas, buscando entender o médico como um ator social inserido em dada realidade e que a constrói cotidianamente. Assim, estaremos examinando os tipos médicos inseridos no mercado de saúde, que, freqüentemente, representam papéis e funçōes múltiplas, concomitantes e complementares. Por meio da análise dos 'assalariados', dos 'liberais', dos novos 'empresários-médicos' e dos 'especialistas' é que iremos compreender um pouco melhor esse complexo universo.

\section{Os liberais}

Atuar em consultório é uma das atividades constitutivas do trabalho médico, por se tratar do local em que o médico se realiza como profissional liberal. No entanto, o rápido avanço do processo de institucionalizaçāo por que passam os setores de prestaçăo de serviços especializados, a visível crise econômico-financeira da clientela e o altíssimo custo da assistência à saúde, em especial dos serviços médicos, praticamente inviabilizam a manutenção dessa prática sem uma associaçăo às empresas que intermediam a prestação de serviços médicos com base no sistema de pré-pagamento. Assim, tornou-se praticamente inviável, tanto para os médicos como para a clientela, arcar individualmente com os custos. A inviabilidade é maior ainda quando envolve atos cirúrgicos ou exames complementares de apoio diagnóstico, freqüentemente sofisticados e de alto custo. De forma simples, pode-se afirmar que a medicina se tornou excepcionalmente capaz de obter preciosos e sofisticados diagnósticos, caros e inacessíveis a quase todos, médicos e pacientes. Estudos, pesquisas, reportagens e debates têm movimentado a agenda dos que se preocupam em formular políticas compatíveis com os interesses dos profissionais e da população.

Mesmo cada vez mais dependentes de contratos com empresas, seguros, medicina de grupo, cooperativas e convênios com o próprio SUS, um enorme contingente de médicos - quase $80 \%$ - continua a manter consultórios. Na região Sul, este índice chega a $88 \%$ (Tabela 4.4). O destaque da prática liberal nessa regiăo năo deve causar estranheza, pois foi exatamente lá que ocorreram os principais movimentos dos médicos em defesa desta prática, com descredenciamento do sistema público, formação de cooperativas, elaboraçāo de propostas de planilhas de custos para a composição do preço dos serviços prestados etc. Não se devem esquecer, igualmente, as características específicas da área no tocante ao mercado de serviços especializados, com grande participação de especialidades típicas da prática privada em consultório. Há uma certa homoge- 
neidade entre as demais regiōes, mas no Sudeste observa-se o menor índice dessa prática $(74,3 \%)$.

Tabela 4.4 - Médicos com atuação em consultório distribuídos por participação em convênio e/ou cooperativa segundo grandes regiōes. Brasil - 1995

\begin{tabular}{lrrrrrrrr}
\hline \multirow{2}{*}{$\begin{array}{l}\text { Brasil e Grandes } \\
\text { Regiöes }\end{array}$} & \multicolumn{2}{c}{ Participa } & \multicolumn{2}{c}{ Não participa } & \multicolumn{2}{c}{ lgnorado } & \multicolumn{2}{c}{ TOTAL } \\
\cline { 2 - 9 } & \multicolumn{1}{c}{ v. abs. } & \multicolumn{1}{c}{$(\%)$} & \multicolumn{1}{c}{ v. abs, } & (\%) & v. abs. & (\%) & v. abs. & $(\%)$ \\
\hline Norte & 3.324 & 80,7 & 790 & 19,2 & 4 & 0,1 & 4.118 & 100,0 \\
Nordeste & 16.913 & 83,2 & 3.401 & 16,7 & 11 & 0,1 & 20.325 & 100,0 \\
Sudeste & 59.053 & 74,3 & 20.287 & 25,5 & 139 & 0,2 & 79.479 & 100,0 \\
Sul & 20.985 & 88,6 & 2.693 & 11,4 & 0 & 0,0 & 23.678 & 100,0 \\
Centro-Oeste & 7.758 & 85,6 & 1.290 & 14,2 & 12 & 0,1 & 9.060 & 100,0 \\
\hline BRASIL - TOTAL & 108.033 & 79,1 & 28.461 & 20,8 & 166 & 0,1 & 136.660 & 100,0 \\
\hline BRASIL - Capitzis & 60.438 & 72,4 & 22.946 & 27,5 & 144 & 0,2 & 83.528 & 100,0 \\
\hline BRASIL - Interiores & 47.595 & 89,6 & 5.515 & 10,4 & 22 & 0,0 & 53.132 & 100,0 \\
\hline
\end{tabular}

Fonte: Pesquisa "Perfil dos Médicos no Brasil", Fiocruz/CFM.

Dentre os profissionais que atuam em consultórios sem convênios, destacamse os que residem na região Sudeste, em especial no estado do Rio de Janeiro, que apresenta o percentual de $39,1 \%{ }^{2}$ Os médicos em fase de paralisaçâo são os que, proporcionalmente, se dedicam à atividade liberal de forma mais acentuada, ainda que menos intensa, sendo exatamente o Rio de Janeiro o estado que concentra o maior contingente de profissionais mais idosos do País.

Essa modalidade de atividade médica é mais afeta aos homens do que às mulheres. Segundo a pesquisa, a participação feminina é de $29,4 \%$, ou seja, a maioria dos consultórios existentes hoje no Brasil são de domínio do universo masculino.

Freqüentemente, a visita do paciente a um consultório médico é associada à recomendação por terceiros quanto à qualificação técnica do médico e sua fama ou prestígio em curar uma enfermidade. Tais atributos são inexoravelmente associados à sua experiência profissional, ou seja, ao tempo em que atua no mercado.

Esse comportamento representa o valor que a 'experiência clínica' possui para os médicos, sendo seguido por sua clientela. Essa experiência, como assinalou Rego (1994), complementa e até contrapõe-se àquela adquirida nos livros, sendo o hospital ou as clínicas com atendimento a pacientes internos os

2 Ver MACHADO et al. (1996:49, v.6). 
locais mais valorizados para sua aquisição. Ao médico em início de carreira, a dedicação ao consultório numa cidade com razoável oferta de serviços pode significar dificuldades adicionais de difícil superação para a conquista da clientela e do respeito profissional de seus pares. Assim, não causa surpresa que apenas $8,4 \%$ dos médicos com menos de quatro anos de formados (em fase de formação, de iniciação profissional) se dediquem exclusivamente à prática em consultório. Aqueles que estão na fase de afirmação e consolidação no mercado de trabalho é que 'dominam' este segmento do mercado, concentrando mais de $70 \%$ das participaçōes. Com a experiência adquirida e sempre renovada com o trabalho hospitalar, certamente selecionam melhor sua clientela, ainda que captada por meio de convênios.

Ao considerar as especialidades dos médicos que atuam em consultório (Tabela 4.5), deparamo-nos com algumas aparentes inconsistências, que trataremos de esclarecer. Referimo-nos à presença de especialidades que, diferentemente, não se caracterizam pela atividade de consultório. Correspondem, em geral, às especialidades burocráticas (administração hospitalar, medicina sanitária, medicina legal, medicina do tráfego).

Algumas das especialidades mais freqüentemente associadas à prática no. consultório com convênios são citopatologia, hematologia, fisiatria, cancerologia, radioterapia, tisiologia, alergia e imunoterapia. Por outro lado, as que estão menos associadas à prática mediante convênios são: genética clínica, hemoterapia, broncoesofagologia, homeopatia, angiologia, eletroencefalografia, psiquiatria, endoscopia digestiva, geriatria e gerontologia, infectologia, medicina do trabalho e nutrologia. Estas especialidades, em sua maioria, estão excluídas por seus objetos específicos de trabalho, que não são habitualmente cobertos pelo sistema privado de pré-pagamento. É o caso dos pacientes acometidos por patologias infecciosas, dos pacientes na terceira idade. As demais podem estar sendo excluídas pela alta tecnologia envolvida, terapêuticas de longo prazo ou por envolverem consultas médicas freqüentes. Tais resultados sugerem que são os convênios de medicina de grupo, seguradoras e cooperativas que não as desejam, em virtude das possíveis despesas adicionais que essas especialidades representariam se fossem regularmente oferecidas. 
Tabela 4.5 - Participaçáo em convênio e/ou cooperativa segundo especialidades.* Brasil - 1995

\begin{tabular}{|c|c|}
\hline Especialidades & $(\%)$ \\
\hline Alergia e Imunoterapia & 92,8 \\
\hline Anestesiologia & 92,2 \\
\hline Angiologia & 57,6 \\
\hline Broncoesofagologia & 50,5 \\
\hline Cancerologia & 94,5 \\
\hline Cardiologia & 77,5 \\
\hline Cirurgia cardiovascular & 81,9 \\
\hline Cirurgia da mão & 76,2 \\
\hline Cirurgia cabeça e pescoço & 84,7 \\
\hline Cirurgia geral & 89,5 \\
\hline Cirurgia pediátrica & 79,9 \\
\hline Cirurgia plástica & 73,8 \\
\hline Cirurgia torácica & 79,5 \\
\hline Cirurgia vascular & 89,5 \\
\hline Citopatologia & 100,0 \\
\hline Dermatologia & 83,2 \\
\hline Eletroencefalografia & 65,2 \\
\hline Endocrinologia e Metabolia & 79,3 \\
\hline Endoscopia digestiva & 68,2 \\
\hline Fisiatria & 96,0 \\
\hline Gastroenterologia & 82,6 \\
\hline Genética clínica & 37,0 \\
\hline Geriatria e Gerontologia & 63,4 \\
\hline Gineco-Obstetrícia & 86,7 \\
\hline Hansenologia & 89,2 \\
\hline Hematologia & 95,2 \\
\hline Hemoterapia & 40,4 \\
\hline Homeopatia & 54,7 \\
\hline Infectologia & 68,0 \\
\hline Mastologia & 83,7 \\
\hline Medicina esportiva & 85,5 \\
\hline Medicina geral comunitária & 76,8 \\
\hline Medicina interna & 75,8 \\
\hline Medicina nuclear & 83,0 \\
\hline Medicina trabalho & 61,5 \\
\hline Nefrologia & 83,2 \\
\hline Neurocirurgia & 70,3 \\
\hline Neurofisiologia clínica & 87,5 \\
\hline Neurologia & 79,8 \\
\hline
\end{tabular}


Tabela 4.5 - Participação em convênio e/ou cooperativa segundo especialidades.* Brasil - 1995 (continuação)

\begin{tabular}{lc}
\hline \multicolumn{1}{c}{ Especialidades } & $(\%)$ \\
\hline Neurologia pediátrica & 67,5 \\
Nutrologia & 50,0 \\
Oftalmologia & 83,9 \\
Ortopedia e Traumatologia & 92,5 \\
Otorrinolaringologia & 89,7 \\
Patologia & 88,8 \\
Patologia clínica & 68,9 \\
Pediatria & 80,3 \\
Pneumologia & 83,8 \\
Proctologia & 84,3 \\
Psiquiatria & 45,8 \\
Radiologia & 76,9 \\
Radioterapia & 93,8 \\
Reumatologia & 81,9 \\
Terapia Intensiva & 84,4 \\
Tisiologia & 100,0 \\
Urologia & 89,7 \\
\hline TOTAL & 79,0 \\
\hline "Foram consideradas apenas as especialidades principais de atuação \\
Fonte: Pesquisa “Perfil dos Médicos no Brasi””, & Fiocruz/CFM. \\
\hline
\end{tabular}

\section{Os liberais e os convênios}

A medicina de grupo e os seguros-saúde constituem um sistema de atendimento médico-hospitalar no qual são oferecidos atendimentos ambulatoriais, consultas médicas e internações. Fundamenta-se no pré-pagamento, pelo cliente, dos serviços demandados. ${ }^{3}$ Os atendimentos são feitos na rede credenciada em nível regional. Esse sistema detém hoje a maior fatia do mercado, abrangendo cerca de 17,5 milhões de beneficiários em todo o País, por meio de 670 empresas que atuam mais fortemente na região Sudeste.

A UNIMED é a maior cooperativa médica do Brasil, sendo composta de $65,7 \%$ dos profissionais conveniados do País, que são, simultaneamente, sócios da cooperativa e prestadores de serviços. Surgiu inicialmente com o objetivo de

3 O cliente paga mensalmente à empresa, que atribui à prestação de senviços médicos um valor " $x$ ", proporcional ao risco estatístico de ele vir a necessitar dos seniços. Os médicos que prestam atendimento receberão o valor arbitrado pela empresa como pagamento de seus seviços no prazo mínimo de um mês após o atendimento. 
manter a idéia básica do sistema de pré-pagamento e autonomia profissional de cada médico. O Sistema Nacional UNIMED agrega onze milhões de pessoas e possui 350 cooperativas, que atendem uma clientela composta basicamente de planos de empresas (80\%), sendo o restante de planos individuais. Seu maior mercado está localizado na região Sul.

Os planos de saúde de 'autogestão' são oferecidos por empresas estatais ou privadas que administram planos de saúde. Estes serviços podem ser oferecidos por meio da contratação de médicos como assalariados das empresas ou da prestação de serviços. A autogestão de conveniados surgiu como uma idéia promissora para evitar o absenteísmo nas empresas e representa uma conquista de trabalhadores organizados em empresas bem estruturadas.

Cabe esclarecer que, neste estudo, 'outras cooperativas' (excluindo-se a UNIMED) engloba os serviços médicos cooperativados, que têm crescido em todo o País. $\mathrm{O}$ convênio-SUS é o contrato entre governo e médico, ou seja, médicos contratados em localidades onde, quase sempre, há carência de atendimento médico especializado ao público. Representa o antigo sistema de saúde previdenciário (INPS, INAMPS).

Os convênios, portanto, são hoje uma realidade na vida dos médicos que decidem assumir a atividade tipicamente liberal da profissão, a fim de assegurar clientela e manter seu estabelecimento aberto, sem sofrer sérios prejuízos. Mas há um preço para essa nova modalidade de captação de clientela: a autonomia do médico ficará condicionada aos interesses e exigências burocráticas impostas pelas empresas que negociam com a suposta clientela.

Desta forma,

para manter seu consultório aberto, os médicos têm que se submeter a estes convênios, porquanto cada vez mais deles dependem tanto econômica quanto financeiramente. Mesmo estando em seu consultório particular, terá que atender a várias exigências burocráticas - preenchimento de papeletas, formulários, guias especiais - e obedecer a normas e códigos organizacionais de cada convênio. Além do mais, o valor de seus serviços estará predeterminado, não sendo permitidas extrapolaçōes e alteraçōes de qualquer ordem. (Machado, 1996:201-202)

Um fato interessante é que, no contexto de uma política de regulação do mercado de serviços médicos, essas empresas privadas - seguros de saúde, medicina de grupo e até mesmo as cooperativas médicas, como a UNIMED, por exemplo - desenvolveram mecanismos regulatórios de tal ordem que promoveram 'espontaneamente' uma certa equiparação salarial entre os médicos. Isto é, perante o contrato de determinado convênio, todos são iguais nos direitos e deveres a serem seguidos por ambas as partes - contratante e contratado. Promoveu-se, assim, a isonomia salarial por meio da fixação de honorários médicos de todos aqueles que prestam serviços em determinada especialidade, estejam eles no início ou no final da carreira profissional. Neste sentido, não há distinção, no mer- 
cado de serviços médicos conveniados, entre profissionais mais ou menos qualificados, entre os experientes e os novatos. É assegurado pagamento igual a todos, diferenciado apenas para aqueles que executem atos e procedimentos mais ou menos complexos (clínicos, diagnósticos ou cirúrgicos). ${ }^{4}$

Em linhas gerais, os dados da pesquisa apontam um mercado de serviços especializados, realizados em consultório, dominados por convênios de medicina de grupo e seguros de saúde, planos de saúde e UNIMEDs, totalizando 73,5\% (Tabela 4.6). Os convênios mais citados pelos médicos por ordem de importância em seu rendimento mensal ${ }^{5}$ são os seguintes: UNIMED $(33,6 \%)$, estatais $(20,3 \%)$, Golden Cross $(8,0 \%)$ e Sul América $(7,6 \%$ ) (Tabela 4.7).

\section{Tabela 4.6 - Distribuição de tipos de convênios e/ou cooperativas segundo grandes regiões.* Brasil - 1995}

\begin{tabular}{|c|c|c|c|c|c|c|c|c|c|c|c|c|}
\hline \multirow{2}{*}{$\begin{array}{c}\text { Tipo de } \\
\text { convênio ou } \\
\text { cooperativa }\end{array}$} & \multicolumn{2}{|c|}{ BRASHL } & \multicolumn{2}{|c|}{ Norte } & \multicolumn{2}{|c|}{ Nordeste } & \multicolumn{2}{|c|}{ Sudeste } & \multicolumn{2}{|c|}{ Sul } & \multicolumn{2}{|c|}{ Centro-Oeste } \\
\hline & v. abs. & $(\%)$ & v. abs. & $(\%)$ & v. abs. & $(\%)$ & v. abs. & (\%) & v. abs. & $(\%)$ & v. abs. & $(\%)$ \\
\hline SUS & 42.334 & 19,4 & 1.117 & 18,9 & 6.867 & 19,7 & 20.641 & 17,6 & 10.062 & 23,0 & 3.647 & 22,5 \\
\hline $\begin{array}{l}\text { Med. grupo/ } \\
\text { Seguro saúde }\end{array}$ & 52.188 & 23,9 & 1.046 & 17,7 & 8.333 & 23,9 & 32.849 & 27,9 & 6.672 & 15,3 & 3.288 & 20,2 \\
\hline $\begin{array}{l}\text { Plano de assist. } \\
\text { médica** }\end{array}$ & 37.049 & 17,0 & 1.032 & 17,4 & 5.668 & 16,3 & 21.684 & 18,4 & 6.160 & 14,1 & 2.505 & 15,4 \\
\hline UNIMED & 71.076 & 32,6 & 2.119 & 35,8 & 11.147 & 32,0 & 34.677 & 29,5 & 18.014 & 41,2 & 5.119 & 31,5 \\
\hline $\begin{array}{l}\text { Outras } \\
\text { cooperativas }\end{array}$ & 13.875 & 6,4 & 549 & 9,3 & 2.496 & 7,2 & 6.658 & 5,7 & 2.689 & 6,1 & 1.483 & 9,1 \\
\hline Ignorado & 1.793 & 0,8 & 62 & 1,0 & 340 & 1,0 & 1.052 & 0,9 & 139 & 0,3 & 200 & 1,2 \\
\hline TOTAL & 218.315 & 100,0 & 5.925 & 100,0 & 34.851 & 100,0 & 117.561 & 100,0 & 43.736 & 100,0 & 16.242 & 100,0 \\
\hline
\end{tabular}

* Cada médico podia declarar mais de um tipo de convênio/cooperativa.

** Plano de assistência médica aos funcionários da própria empresa (autogestão).

Fonte: Pesquisa "Perfil dos Médicos no Brasil", Fiocruz/CFM.

4 A própria AMB reforçou a concepção isonômica através de sua Tabela de Honorários Médicos. Considerando-se as circuntâncias históricas de sua criaçāo, esta observaçăo nāo está imbuída de qualquer conotação valorativa, o que demandaria um tipo de análise que extrapola os objetivos deste livro.

5 O SUS ocupa o segundo lugar ao serem considerados os convênios individualmente, logo após a UNIMED. Entretanto, para a elaboração do ranking relativo à sua importância no financiamento do consultório, nāo era possivel a inclusāo deste convênio, já que a pergunta referia-se explicitamente ao sistema de medicina de grupo/seguros/cooperativas. 
Tabela 4.7 - Distribuição percentual dos tipos de convênios/cooperativas segundo local de moradia.* Brasil - 1995

\begin{tabular}{lrrr}
\hline \multicolumn{1}{c}{$\begin{array}{c}\text { Convênios/ } \\
\text { cooperativas** }\end{array}$} & Capitais & Interiores & BRASIL \\
\cline { 2 - 4 } & $(\%)$ & $(\%)$ & \multicolumn{1}{c}{$(\%)$} \\
\hline Estatais*** & 12,0 & 8,3 & 20,3 \\
SUS & 1,7 & 3,9 & 5,6 \\
INAMPS & 0,1 & - & 0,1 \\
Amil & 2,9 & 0,1 & 3,0 \\
Golden Cross & 7,4 & 0,6 & 8,0 \\
Bradesco & 4,8 & 2,0 & 6,8 \\
Sul América & 6,0 & 1,6 & 7,6 \\
Bamerindus & 2,3 & 0,9 & 3,2 \\
Outros planos privados & 7,9 & 3,1 & 11,0 \\
UNIMED & 15,6 & 18,0 & 33,6 \\
Outras cooperativas & 0,7 & 0,1 & 0,8 \\
\hline TOTAL & 61,4 & 38,6 & 100,0 \\
\hline
\end{tabular}

* Somente dentre aqueles que declararam o nome do convênio e foi possivel identificá-lo.

* Refere-se aos convénios declarados pelos médicos como os mais importantes para a sua renda mensal.

*** Dentre as empresas estatais sobressaíram: Banco do Brasil, Geap/Patronal, Funcep, Petrobrás, Capesaúde.

Fonte: Pesquisa "Perfil dos Médicos no Brasil", Fiocruz/CFM.

\section{Os assalariados}

O assalariamento, no setor público ou privado, é uma modalidade consolidada e representa hoje a mais importante forma de inserção no mercado de serviços dos médicos. Denominamos como assalariamento todas as formas de trabatho institucionalizadas, por meio das quais o profissional presta seus serviços, esteja o vínculo formalizado ou não sob a égide das leis trabalhistas. Na verdade, os dados empíricos disponíveis levam a crer que boa parte desse contigente de assalariados não dispõe de formalização no contrato de trabalho estabelecido entre ele e o comprador dos serviços.

Curiosamente, os dados da pesquisa revelam também uma certa homogeneidade do mercado de trabalho desses assalariados, nas instituições tanto públicas quanto privadas, em especial quanto ao salário, às áreas e modalidades de atendimento e à avaliação que os médicos fazem desses estabelecimentos. As Tabelas 4.8 
e 4.9 sugerem uma certa homogeneidade de mercados, ou seja, praticamente nāo se encontram formas puras de inserção profissional.

Esses dados e a leitura cuidadosa de milhares de questionários nos permitem afirmar, resumidamente, que os médicos assalariados do setor público são mais jovens, o contingente feminino é tendencialmente maior e, em decorrência do modelo assistencial adotado pelo Estado brasileiro, eles atuam, predominantemente, em áreas básicas - gineco-obstetrícia, medicina interna (clínica geral), pediatria e cirurgia geral. Dotado de hospitais gerais de grande porte, de hospitais-escolas e de uma extensa e importante rede ambulatorial, esse setor polariza dois contigentes de médicos: jovens em busca de profissionalização para o mercado (residência médica), constituindo $27,8 \%$ dos que optam pelo vínculo único; e médicos em fase de consolidação da vida profissional, que têm o maior percentual de participação.

A nosso ver, dois fatores interferem nessa realidade. Primeiro, a maioria dos concursos públicos (quase todos federais), assegurando salários compativeis com os do mercado em geral, ocorreram exatamente na década de 70 . Segundo, são estes médicos, detentores de sólida e reconhecida experiência, que dominam a maioria das instituiçōes que oferecem formaçāo profissional em nível de graduação e pósgraduação (lato e stricto sensu). Em ambas as situaçōes, essas instituiçōes empregadoras estabelecem vínculos trabalhistas formais e fomentam a dedicação exclusiva.

Já a análise do setor privado sugere um mercado que absorve um pequeno contingente jovem, em especial os que estão em fase de profissionalização formal. As mulheres, por sua vez, nāo buscam preferencialmente este setor para trabalhar; 0 vínculo trabalhista tende a ser mais informal, admitindo-se uma variedade imensa de formas de prestação e contratação dos serviços médicos. Coerentemente com o modelo assistencial no Brasil, as instituiçōes privadas adotam um modelo mais hospitalar (quase $80 \%$ dos leitos existentes são privados), especializado e desenvolvido em estabelecimentos de médio e pequeno portes. A tradição desse setor tem sido prestar assistência hospitalar especializada, com alta concentração nos centros urbanos de grande capacidade de investimentos, abrangendo, assim, as áreas e serviços mais rentáveis para o sistema privado. Com isto, aglutinam os médicos-cirurgiōes, os anestesistas e os especialistas em enfermidades que envolvem tecnologia de ponta e recursos de apoio diagnóstico sofisticados.

À primeira vista, somos tentados a identificar os médicos, que atuam exclusivamente no setor privado, no consultório ou de forma simultânea nesses dois segmentos do mercado, como profissionais que não dependem do serviço público para o 'financiamento' de suas atividades. Mas isto nāo é verdade. Tanto as clínicas e hospitais privados, como os consultórios particulares mantêm, em grande número, convênios com o SUS. Buscaríamos, então, um pretenso segmento 'nāo-dependente' do Estado entre as clínicas e consultórios que não possuem convênios públicos. Vinculados apenas aos convênios privados, formariam este segmento de mercado. Novamente, tais argumentos não resistem ao confronto com a realidade, já que o Estado também contribui para o financiamento deles por meio da renúncia fiscal, 
caracterizada pelo abatimento oferecido a despesas médico-hospitalares no imposto de renda. Assim, mesmo o profissional que atua em seu consultório, ainda que não trabalhe mediante convênio, é indiretamente financiado pelo Estado. Estado esse que foi competente no financiamento da expansão da rede privada hospitalar na década de 70 e que hoje é incapaz de formular políticas que regulem um setor tão amparado por seus recursos.

Enfim, apesar da tentativa de analisar separadamente a inserção 'pura' ou a natureza das instituiçōes (pública, privada ou consultório), os dados qualitativos e quantitativos nos levam a crer que o mais prudente e compatível com nossa proposta analítica é a 'inserção múltipla', que concentra a maioria dos médicos (Tabelas 4.8 e 4.9). O fato de os médicos prestarem serviços essenciais e de domínio, controle e responsabilidade do Estado faz com que as formas, as condições e as necessidades dos usuários se conformem a um mercado de serviços com acentuada homogeneidade, constituindo, assim, um quadro de significativa importância para se pensar a estruturação desse mercado.

Desse modo, a alta incidência de regulação (necessária e imprescindível) na produção, distribuição e manutenção dos senviços médicos ocasiona essa homogeneidade na prestação e absorção desses serviços em todo o território nacional.

\section{Os assalariados e a atividade de plantão}

Por oferecer serviços vitais à manutençăo dos indivíduos, a atividade médica tornou-se indispensável e é oferecida 24 horas por dia, não podendo ser interrompida na rotina de um hospital. O plantão surge dessa necessidade básica e, portanto, é uma atividade inerente à vida do médico. Os dados da pesquisa mostram que $48,8 \%$ dos profissionais fazem plantão (Tabela 4.10 ) e esse índice chega a $60,0 \%$ na regiăo Centro-Oeste.

A função de plantonista é exercida fundamentalmente por médicos em início de carreira $-61,6 \%$ deles têm até 39 anos de idade (Tabela 4.11). Săo eles que, em geral, assumem esta modalidade de assistência médica, freqüentemente desgastante, exigindo intensa concentraçăo, perfazendo 6,12 ou 24 horas em atividade. A maioria desses médicos trabalha entre 12 e 48 horas mensais de plantão, sendo esta média mantida em todas as regióes brasileiras (Tabela 4.12). No interior, observa-se um significativo aumento de profissionais que acumulam mais de 48 horas de plantăo, acusando uma sobrecarga para os que atuam nessas áreas. Em boa parte, tal fato justifica-se pela ausência de médicos em número suficiente nos hospitais do interior. 


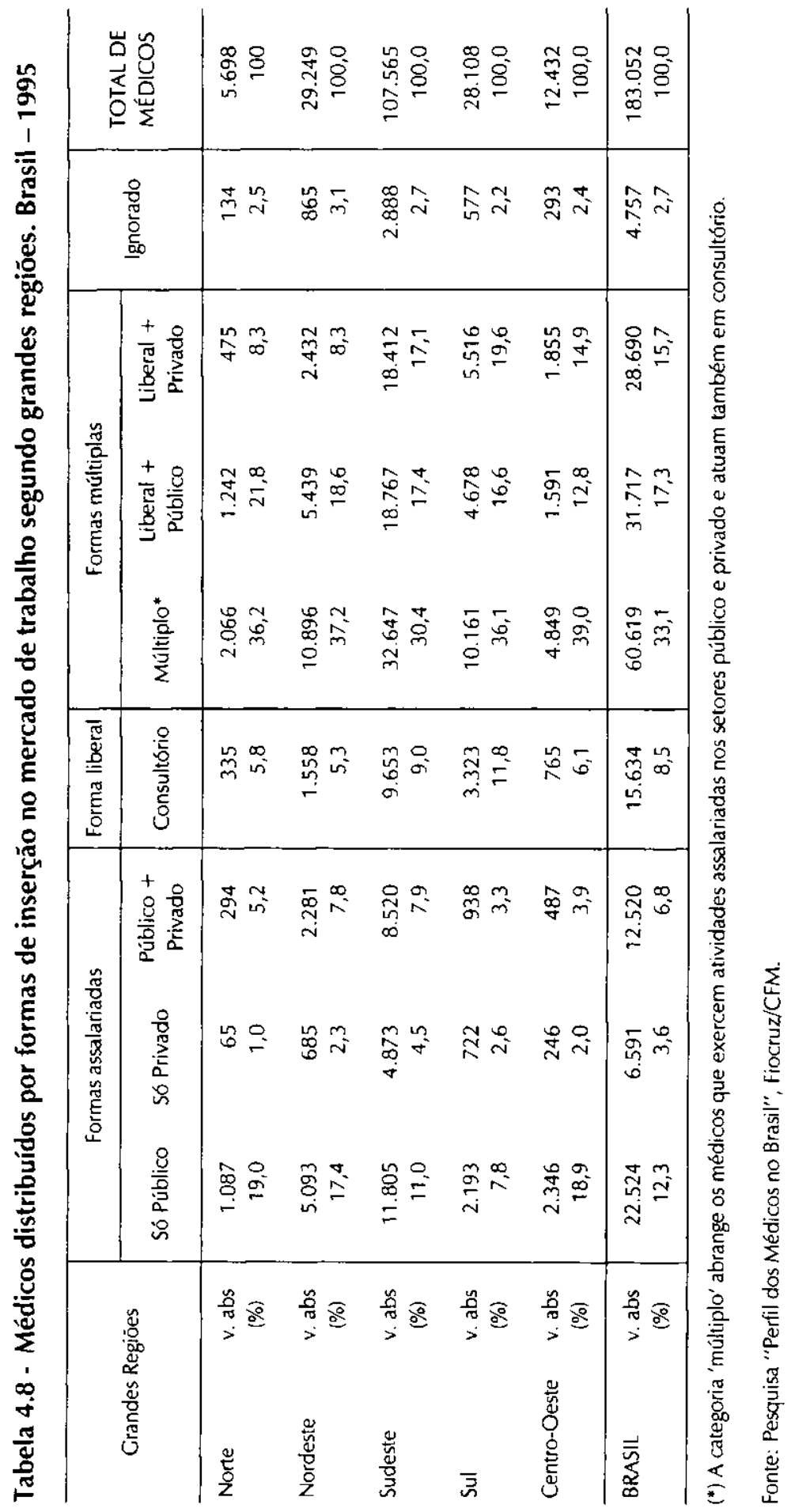




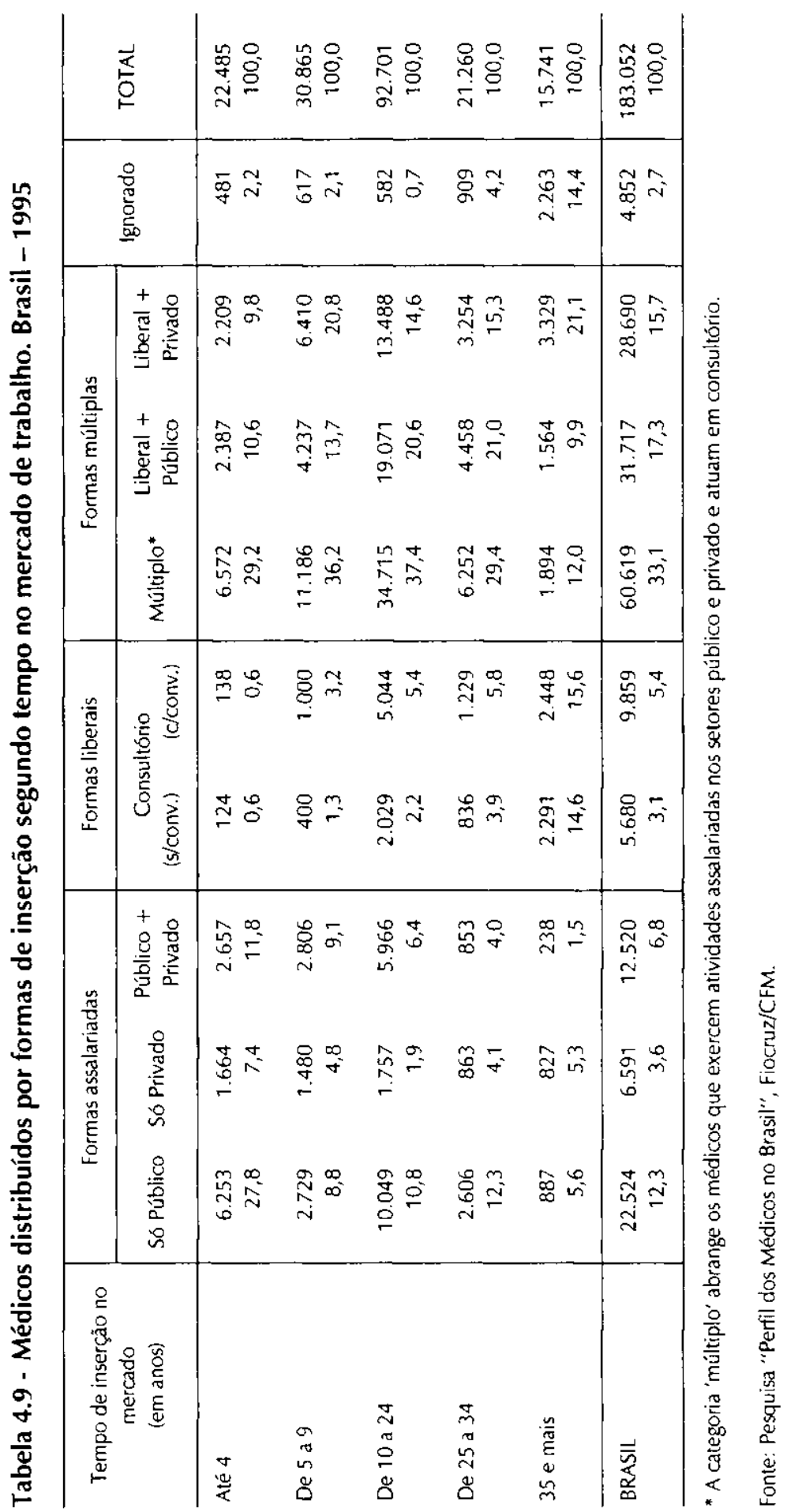


Tabela 4.10 - Médicos plantonistas segundo grandes regióes. Brasil - 1995

\begin{tabular}{lrl}
\hline \multirow{2}{*}{ Grandes Regiões } & \multicolumn{2}{c}{ Plantonistas } \\
\cline { 2 - 3 } & v. abs. & $(\%)^{*}$ \\
\hline Norte & 2.638 & 46,3 \\
Nordeste & 13.755 & 47,0 \\
Sudeste & 51.727 & 48,0 \\
Sul & 13.912 & 49,4 \\
Centro-Oeste & 7.463 & 60,0 \\
\hline BRASIL - TOTAL & 89.495 & 48,8 \\
\hline BRASIL - Capitais & 54.421 & 45,1 \\
\hline BRASIL - Interiores & 35.074 & 56,2 \\
\hline
\end{tabular}

* Percentual relativo ao total de médicos por regiāo.

Fonte: Pesquisa "Perfil dos Médicos no Brasil", Fiocruz/CFM.

Embora os dados disponíveis sejam insuficientes para demonstrar a correspondência entre tempo de formado e modalidade de plantão (presente no local ou de sobreaviso), é possível estabelecer uma correlação entre os que estão iniciando a carreira com o plantão no local, e entre os que já se estabeleceram profissionalmente com o plantão de sobreaviso. Esta última modalidade permite que o médico esteja de 'plantão virtual' em determinado hospital sem estar fisicamente no local, sendo sua presença requerida quando necessária.

Tabela 4.11 - Médicos plantonistas distribuídos por local de moradia segundo faixa etária.* Brasil - 1995

\begin{tabular}{|c|c|c|c|c|c|c|c|c|c|}
\hline \multirow{2}{*}{$\begin{array}{l}\text { Local de } \\
\text { Moradia }\end{array}$} & \multicolumn{2}{|c|}{ Capitais } & \multicolumn{2}{|c|}{ Interiores } & \multicolumn{2}{|c|}{ BRASIL } & \multicolumn{3}{|c|}{ Freqüência acumulada (\%) } \\
\hline & v. abs. & $(\%)$ & v. abs. & $(\%)$ & v. abs. & $(\%)$ & Capitais & Interiores & TOTAL \\
\hline Até 29 & 13.059 & 24,0 & 5.158 & 14,7 & 18.217 & 20,4 & 24,0 & 14,7 & 20,4 \\
\hline De 30 a 39 & 22.625 & 41,6 & 14.268 & 40,7 & 36.893 & 41,2 & 65,6 & 55,4 & 61,6 \\
\hline De 40 a 49 & 13.959 & 25,7 & 11.256 & 32,1 & 25.215 & 28,2 & 91,2 & 87,5 & 89,8 \\
\hline De 50 a 59 & 3.721 & 6,8 & 3.519 & 10,0 & 7.240 & 8,1 & 98,1 & 97,5 & 97,8 \\
\hline 60 e mais & 1.057 & 1,9 & 873 & 2,5 & 1.930 & 2,2 & 100,0 & 100,0 & 100,0 \\
\hline TOTAL & 54.421 & 100,0 & 35.074 & 100,0 & 89.495 & 100,0 & - & - & - \\
\hline
\end{tabular}

Fonte: Pesquisa "Perfil dos Médicos no Brasil", Fiocruz/CFM. 
Tabela 4.12 - Médicos plantonistas distribuídos por número de horas trabalhadas segundo grandes regióes. Brasil - 1995

\begin{tabular}{|c|c|c|c|c|c|c|c|c|c|c|c|c|}
\hline \multirow{2}{*}{$\begin{array}{l}\text { Grandes } \\
\text { Regiōes }\end{array}$} & \multicolumn{2}{|c|}{$\begin{array}{c}\text { Menos de } \\
12 \mathrm{~h}\end{array}$} & \multicolumn{2}{|c|}{ De 12 a $24 h$} & \multicolumn{2}{|c|}{ De 25 a $48 h$} & \multicolumn{2}{|c|}{ Mais de $48 \mathrm{~h}$} & \multicolumn{2}{|c|}{ Ignorado } & \multicolumn{2}{|c|}{ TOTAL } \\
\hline & v. abs. & $(\%)$ & v. abs. & $(\%)$ & v. abs. & $(\%)$ & v. abs. & $(\%)$ & v. abs. & $(\%)$ & v. abs. & $(\%)$ \\
\hline Norte & 104 & 3,9 & 1.216 & 46,1 & 738 & 28,0 & 555 & 21,1 & 25 & 0,9 & 2.638 & 100,0 \\
\hline Nordeste & 504 & 3,7 & 7.030 & 51,1 & 3.767 & 27,0 & 2.353 & 17,1 & 101 & 0,7 & 13.755 & 100,0 \\
\hline Sudeste & 2.827 & 5,5 & 25.557 & 49,4 & 14.266 & 27,6 & 8.882 & 17,1 & 195 & 0,4 & 51.727 & 100,0 \\
\hline Sul & 944 & 6,8 & 6.369 & 45,8 & 3.422 & 24,6 & 2.935 & 21,1 & 242 & 1,7 & 13.912 & 100,0 \\
\hline Centro-Oeste & 565 & 7,6 & 3.666 & 49,1 & 1.908 & 25,6 & 1.237 & 16,6 & 85 & 1,1 & 7.463 & 100,0 \\
\hline BRASIL - TOTAL & 4.944 & 5,5 & 43.838 & 49,0 & 24.101 & 26,9 & 15.964 & 17,9 & 648 & 0,7 & 89.495 & 100,0 \\
\hline BRASIL - Capitais & 3.077 & 5,7 & 28.900 & 53,1 & 15.386 & 28,3 & 9.117 & 12,6 & 211 & 0,4 & 54.421 & 100,0 \\
\hline BRASIL - Interiores & 1.867 & 5,3 & 14.938 & 42,6 & 8.715 & 24,8 & 6.847 & 26,0 & 437 & 1,2 & 35.074 & 100,0 \\
\hline
\end{tabular}

Fonte: Pesquisa "Perfil dos Médicos no Brasil”, Fiocruz/CFM.

Tabela 4.13 - Médicos plantonistas distribuídos por tipo de plantão segundo grandes regióes. Brasil - 1995

\begin{tabular}{|c|c|c|c|c|c|c|c|c|c|c|}
\hline \multirow{2}{*}{$\begin{array}{l}\text { Grandes } \\
\text { Regiōes }\end{array}$} & \multicolumn{2}{|c|}{$\begin{array}{c}\text { Presente no } \\
\text { local }\end{array}$} & \multicolumn{2}{|c|}{ Sobreaviso } & \multicolumn{2}{|c|}{ Ambos } & \multicolumn{2}{|c|}{ Ignorado } & \multicolumn{2}{|c|}{ TOTAL } \\
\hline & v. abs. & $(\%)$ & v. abs. & $(\%)$ & v. abs. & $(\%)$ & v. abs. & $(\%)$ & v. abs. & $(\%)$ \\
\hline Norte & 1.718 & 65,1 & 707 & 26,8 & 177 & 6,7 & 36 & 1,4 & 2.638 & 100,0 \\
\hline Nordeste & 11.471 & 83,4 & 1.487 & 10,8 & 682 & 5,0 & 115 & 0,8 & 13.755 & 100,0 \\
\hline Sudeste & 36.868 & 71,3 & 10.298 & 19,9 & 3.940 & 7,6 & 621 & 1,2 & 51.727 & 100,0 \\
\hline Sul & 7.808 & 56,1 & 4.792 & 34,4 & 1.204 & 8,7 & 108 & 0,8 & 13.912 & 100,0 \\
\hline Centro-Oeste & 5.283 & 70,8 & 1.698 & 22,8 & 443 & 5,9 & 39 & 0,5 & 7.463 & 100,0 \\
\hline BRASIL - TOTAL & 63.148 & 70,6 & 18.982 & 21,2 & 6.446 & 7,2 & 919 & 1,0 & 89.495 & 100,0 \\
\hline BRASIL - Capitais & 45.497 & 83,6 & 5.376 & 9,9 & 2.857 & 5,2 & 691 & 1,3 & 54.421 & 100,0 \\
\hline BRASIL - Interiores & 17.651 & 50,3 & 13.606 & 38,8 & 3.589 & 10,2 & 228 & 0,7 & 35.074 & 100,0 \\
\hline
\end{tabular}

Fonte: Pesquisa "Perfil dos Médicos no Brasil", Fiocruz/CFM

\section{Os empresários}

Para Nogueira (1991:119), o médico-empresário é

aquele que gerencia seu próprio negócio, mas também é detentor principal dos conhecimentos e das habilidades requeridas por seu produto, ou seja, condensa em si as funçōes de trabalhador e de empresário. ${ }^{6}$

Nesta perspectiva, esse profissional com duplo papel acaba mantendo de forma mais segura a autonomia técnica e econômica requerida pela medicina. Esses

6 O 'empresário de saúde' foi considerado na pesquisa como médico proprietário ou sócio de um estabelecimento de saúde, independentemente dos vínculos que exercia no mercado de trabalho. 
médicos constituem um segmento reduzido e privilegiado da profissão: representam $18,4 \%$ do total, concentrando-se especialmente nas regiōes Centro-Oeste, onde um quarto dos médicos são empresários de saúde, e Nordeste, onde essa proporção é de um quinto (Tabela 4.14).

Tabela 4.14 - Médicos empresários de saúde segundo grandes regiões. Brasil - 1995

\begin{tabular}{lcc}
\hline \multirow{2}{*}{ Grandes Regiōes } & \multicolumn{2}{c}{ Empresários } \\
\cline { 2 - 3 } & v. abs. & $(\%)^{*}$ \\
\hline Note & 1.075 & 18,9 \\
Nordeste & 5.885 & 20,1 \\
Sudeste & 18.178 & 16,9 \\
Sul & 5.214 & 18,5 \\
Centro-Oeste & 3.347 & 26,9 \\
\hline BRASIL - TOTAL & 33.699 & 18,4 \\
\hline BRASIL - Capitais & 20.014 & 16,6 \\
\hline BRASIL - Interiores & 13.685 & 21,9 \\
\hline
\end{tabular}

* Percentual relativo ao total de médicos por região.

Fonte: Pesquisa "Perfil dos Médicos no Brasil", Fiocruz/CFM.

Adotando a rotina de empresário e médico, estes profissionais acabam acumulando trabalho, ou seja, a metade possui mais de três atividades médicas além da empresarial. Em sua maioria, essas empresas são clínicas e hospitais, e, com menor importância, surgem as cooperativas médicas. Sabe-se, no entanto, que esta nova modalidade de empresariamento nos serviços médicos - a cooperativa - é fruto das recentes transformaçōes do mundo do trabalho, não constituindo, à época da pesquisa, um segmento empresarial expressivo.

Os médicos-empresários possuem algumas características que os tornam um tipo profissional especial. São jovens - 34\% deles têm até 34 anos, e quase $80 \%$ têm menos de 50 anos de idade. Este fato reforça a idéia de que o empresariamento da saúde por médicos é um fenômeno recente no Brasil, com a baixa concentração de profissionais mais velhos (com mais de 60 anos), somando apenas $8,8 \%$. Predominantemente, são do sexo masculino, desenvolvem suas atividades nas capitais e são especializados nas seguintes áreas: pediatria, ortopedia e traumatologia, anestesiologia, cardiologia e cirurgia-geral. Além disso, buscam dar continuidade ao 'negócio de família', ou seja, $50 \%$ deles têm pais ou parentes médicos, sugerindo a idéia de manutençăo do status adquirido pelos familiares. 


\section{AS FASES DA VIDA PROFISSIONAL DO MÉDICO}

\section{Iniciando-se na vida profissional}

Os primeiros anos após a graduação são marcados pela busca de uma inserção efetiva no mercado de trabalho. Enquanto estudantes, vão progressivamente se iniciando nos hospitais universitários, tentando estabelecer os primeiros vínculos com o mercado de trabalho médico por meio de estágios extracurriculares. Será nesses estágios que a maioria deles atuará efetivamente como médico, até mesmo com graus de autonomia incompatíveis com seu nível de formação. Tais vínculos, muitas vezes remunerados, representam, para muitos deles, a perspectiva de um emprego/estágio após a graduação ou, no mínimo, um incremento em sua experiência clínica (Rego, 1994).

Depois de formados, os primeiros anos da vida profissional são marcados pela procura de uma especialização. $O$ médico passa a estabelecer os primeiros vínculos - muitas vezes, informais - com o mercado profissional. Constituído de jovens com menos de 30 anos, este contingente, em fase de 'iniciação da vida profissional', representa $12,3 \%$ dos médicos. Vivem, em sua maioria absoluta, nas capitais - mais de dezesseis mil dentre os 22.485 médicos jovens (Tabela 4.15). Um contingente expressivo - $77,0 \%$ - localiza-se nas regiôes Sul e Sudeste, e, desse percentual, mais da metade reside no estado de São Paulo (Tabelas 4.16 e 4.17). Tal fenômeno pode ser explicado pela concentração acentuada, nessa parte do País, de escolas médicas e de programas de especialização, especialmente residência médica, em particular no eixo São Paulo-Rio de Janeiro-Belo Horizonte. Por outro lado, o fato de a maioria dos programas de residência serem desenvolvidos em instituiçóes públicas justifica a maior presença $(42,1 \%)$ destes jovens médicos no setor público (Tabela 4.18).

Por estarem iniciando suas atividades profissionais e, em sua maioria, se encontrarem em processo de 'especialização' para o mercado, o número de atividades que os médicos jovens desempenham (Tabela 4.19) é comparativamente menor do que nos demais segmentos, excetuando os que estão na fase de 'paralisaçăo' (médicos com mais de 35 anos de inserção no mercado de trabalho). Desse contingente em fase de 'iniciação', $49,3 \%$ exercem no máximo duas atividades, com ênfase para aquela desenvolvida no setor público.

De recente inserção no mercado, tendo poucas atividades remuneradas e quase sempre em fase de formação profissional, esse grupo tem rendimentos inferiores aos das demais faixas etárias: ganham até mil dólares. A faixa modal para este segmento é de 786,1 dólares (Tabela 4.20). 


\section{Afirmando-se no mercado}

A segunda fase - denominada 'afirmação no mercado de trabalho' - é constituída por mais de trinta mil médicos e se diferencia do contingente anterior por várias razōes. A primeira refere-se a sua inserção no mercado, ou seja, esses profissionais já se encontram 'especializados para o mercado', visto que, em sua maioria, fizeram algum programa de especialização - residência e/ou curso de especialização.

A segunda diferença está na concentração urbana: enquanto $72,5 \%$ dos médicos com menos de trinta anos estão nas capitais, o contingente em questăo apresenta um percentual de $65,1 \%$ (Tabela 4.15). Esses dados se justificam se considerarmos que, nessa fase de vida profissional (entre cinco e nove anos), o médico recémprofissionalizado busca inserir-se no mercado de trabalho, estando mais propenso a atuar no interior do País, mesmo que sua origem seja urbana, e a tendência geral, conforme o capítulo 2, seja para a urbanização. Os dados das Tabelas 4.16 e 4.17 elucidam este fenômeno de concentração nas regiōes Sul e Sudeste $(77,3 \%$ dos médicos nessa fase), com ênfase nos estados de São Paulo, Rio de Janeiro, Minas Gerais e Rio Grande do Sul.

A terceira diferença refere-se ao tipo de setor em que o médico, nessa fase, está inserido: ele reduz a participação no setor público (de $42,1 \%$ para $31,7 \%$ ), aumenta no setor privado $(33,1 \%)$ e inicia efetivamente as atividades em consultório $35,2 \%$ deles se dedicam a elas (Tabela 4.18 ).

Com uma especialidade já definida para atuar no mercado de serviços médicos, esses profissionais começam a diversificar ainda mais as áreas de inserção e passam a conviver mais claramente com o múltiplo emprego, acumulando várias atividades. Por exemplo, 60,6\% dos médicos (Tabela 4.19), com cinco a nove anos no mercado, têm três ou mais atividades.

Sua remuneração, entretanto, fica muito aquém da jornada de trabalho extensa e intensa (Tabela 4.20). Freqüentemente, associando atividades em locais diferentes - que exigem cumprimento de horário e produtividade de acordo com a política organizacional da instituição - com a atuação em consultório de clientela ainda incipiente, esses médicos percebem salários baixos em cada uma das atividades, perfazendo uma renda mensal de apenas 1.053,6 dólares (valor modal).

\section{Consolidando-se na vida profissional}

$\mathrm{Na}$ chamada fase de 'consolidação' da vida profissional, concentram-se os médicos que estão em atividade há mais de dez e menos de 25 anos, totalizando mais de noventa mil, ou seja, 50,6\% de todo o contingente do País. De modo mais semelhante ao segmento anterior, estes profissionais são os que dominam (qualitativa e quantitativamente) o mercado de serviços, seja nas capitais ou interior, seja nas instituições privadas ou públicas que compōem o sistema de saúde, 
seja ainda em seus consultórios, nos quais passam a ser mais seletivos com os contratos firmados com as empresas e seguradoras. Um percentual menor do que os inseridos nas fases anteriores $(72,0 \%)$ está concentrado nas regiōes Sul e Sudeste (Tabelas 4.15, 4.16 e 4.17). Neste e no segmento que o sucede, são observadas as menores proporções de médicos na regiăo Sudeste, ou seja, $56,3 \%$ e $53, \%$, respectivamente, sugerindo um movimento migratório que, entretanto, é impossivel comprovar com as informações disponíveis.

A atuação no mercado por natureza do setor também diferencia estes médicos daqueles recém-formados, ou seja, enquanto $42,1 \%$ destes últimos atuam em instituições públicas e $27,0 \%$ mantêm atividades em consultórios, estes percentuais se alteram sensivelmente na fase de 'consolidação', que cai para $34,9 \%$ no setor público e cresce para $37,2 \%$ no consultório (Tabela 4.18).

Em relação ao número de atividades por médico, estes últimos profissionais têm comportamento muito semelhante aos daqueles que se encontram na fase de 'afirmação no mercado de trabalho'. São médicos com idade entre trinta e 49 anos, que têm jornadas de trabalho mais extensas, acumulando várias atividades (Tabela 4.19). No entanto, o que vai diferenciar qualitativamente estes dois segmentos é a renda mensal: enquanto os médicos que se encontram na fase de 'afirmação' no mercado percebem renda mensal com valor modal de apenas 1.053,6 dólares, os da fase de 'consolidação' recebem 1.595,9 dólares (Tabela 4.20). Como veremos mais adiante, provavelmente são a modalidade e o volume de convênios firmados nos consultórios aliados a uma melhor inserção nas instituições públicas e privadas que garantem, ainda que acanhada, uma certa melhoria salarial.

\section{Desacelerando as atividades médicas}

$\mathrm{Na}$ fase de 'desaceleração' no mundo do trabalho, caracterizada por um contingente médico com 50 a 59 anos de idade, os médicos estão, de modo geral, há mais de 25 anos no mercado e buscam reduzir as atividades. Em sua maioria, atuam em até duas atividades $(48,4 \%)$, conciliando um emprego (público ou privado) com a atividade em consultório. Sua distribuição proporcional entre regiōes se altera, apresentando um crescimento nas regiōes Nordeste, Sul e Centro-Oeste (Tabela 4.17) e nas capitais (Tabela 4.15), sugerindo a possibilidade de intensificação dos movimentos migratórios nesta fase. Mais especificamente, os dados das Tabelas 4.16 e 4.17 sugerem esta 'desaceleração' nas duas regiōes mais desenvolvidas (Sul e Sudeste), com um percentual de $70,4 \%$ dos médicos ali concentrados.

A participação da atividade em consultório é privilegiada por este segmento médico, representando o maior percentual entre as três atividades: $38,7 \%$ (Tabela 4.18). Por outro lado, com uma posição mais tranqüila no mercado, eles passam a trabalhar 'menos', qualificando melhor seus serviços e garantindo uma renda mensal mais eleva- 
da (Tabela 4.20), embora, em média, ainda muito aquém da representação social da profissão. O valor modal encontrado foi três vezes superior (2.133,2 dólares) ao dos médicos que estāo em fase de 'iniciaçäo' da vida profissional.

\section{Paralisando a vida profissional}

Constituído por médicos com mais de setenta anos de idade, este segmento representa o menor número de profissionais, ou seja, pouco menos de quinze mil, e se encontra na fase de 'paralisação' das atividades. Em alguns aspectos, esses médicos se assemelham aos que estão iniciando sua carreira. Os dados das Tabelas 4.15 e 4.16 reforçam esta análise. Os estados de São Paulo e Rio de Janeiro respondem por $60,0 \%$ de todo o contingente desta fase (9.543 dentre 15.741) (Tabela 4.17). Trabalhando menos, reduzindo as atividades profissionais, esta parcela de médicos possui a maior renda modal (2.192,04 dólares) (Tabela 4.20). Vários fatores induzem $a$ isso: constituem um contingente pequeno, homogêneo e, embora por motivos distintos e muitas vezes divergentes, estão concentrados também nas capitais $(74,7 \%)$ e nas regióes Sul e Sudeste $(\mathbf{8 0}, 2 \%)$. Possivelmente associado a processos de aposentadoria, verifica-se o fato de que a participação em atividades nos setores público e privado diminui significativamente, mantendo-se aquelas do setor privado e as de consultório (Tabelas 4.18 e 4.19).

Tabela 4.15 - Médicos distribuídos por local de moradia segundo tempo de inserção no mercado de trabalho. Brasil - 1995

\begin{tabular}{lccrrrr}
\hline \multirow{2}{*}{$\begin{array}{c}\text { Tempo de inserçäo } \\
\text { (em anos) }\end{array}$} & \multicolumn{2}{c}{ Capitais } & \multicolumn{2}{c}{ Interiores } & \multicolumn{2}{c}{ BRASIL } \\
\cline { 2 - 7 } & v. abs. & $(\%)$ & v. abs. & $(\%)$ & v. abs. & $(\%)$ \\
\hline Até 4 & 16.294 & 72,5 & 6.191 & 27,5 & 22.485 & 100,0 \\
De 5 a 9 & 20.104 & 65,1 & 10.761 & 34,9 & 30.865 & 100,0 \\
De 10 a 24 & 58.371 & 63,0 & 34.330 & 37,0 & 92.701 & 100,0 \\
De 25 a 34 & 14.130 & 66,5 & 7.130 & 33,5 & 21.260 & 100,0 \\
35 e mais & 11.763 & 74,7 & 3.978 & 25,3 & 15.741 & 100,0 \\
\hline TOTAL & 120.662 & 65,9 & 62.390 & 34,7 & 183.052 & 100,0 \\
\hline
\end{tabular}

Fonte: Pesquisa "Perfil dos Médicos no Brasil", Fiocruz/CFM. 
Tabela 4.16 - Médicos distribuídos por grandes regiōes segundo tempo de inserção no mercado. Brasil - 1995

\begin{tabular}{|c|c|c|c|c|c|c|c|c|c|c|c|c|}
\hline \multirow{2}{*}{$\begin{array}{l}\text { Tempo de } \\
\text { inserção } \\
\text { (em anos) }\end{array}$} & \multicolumn{2}{|c|}{ BRASIL } & \multicolumn{2}{|c|}{ Norte } & \multicolumn{2}{|c|}{ Nordeste } & \multicolumn{2}{|c|}{ Sudeste } & \multicolumn{2}{|c|}{ Sul } & \multicolumn{2}{|c|}{ Centro-Oeste } \\
\hline & v. abs. & (\%) & v. abs. & $(\%)$ & v. abs. & (\%) & v. abs. & $(\%)$ & v. abs. & $(\%)$ & v. abs. & $(\%)$ \\
\hline Até 4 & 22.485 & 12,3 & 470 & 8,2 & 2.981 & 10,2 & 13.872 & 12,9 & 3.607 & 12,8 & 1.561 & 12,6 \\
\hline De 5 a 9 & 30.865 & 16,9 & 837 & 14,6 & 4.241 & 14,5 & 19.021 & 17,7 & 4.849 & 17,2 & 1.917 & 15,4 \\
\hline De 10 a 24 & 92.701 & 50,6 & 3.329 & 58,04 & 16.106 & 55,1 & 52.202 & 48,5 & 14.543 & 51,7 & 6.521 & 52,5 \\
\hline De 25 a 34 & 21.260 & 11,6 & 684 & 12,1 & 3.935 & 13,5 & 11.379 & 10,6 & 3.585 & 12,8 & 1.677 & 13,5 \\
\hline 35 e mais & 15.741 & 8,6 & 378 & 6,7 & 1.986 & 6,8 & 11.091 & 10,3 & 1.530 & 5,5 & 756 & 6,1 \\
\hline TOTAL & 183.052 & 100,0 & 5.698 & 100,0 & 29.249 & 100,0 & 107.565 & 100,0 & 28.108 & 100,0 & 12.432 & 100,0 \\
\hline
\end{tabular}

Fonte: Pesquisa "Perfil dos Médicos no Brasil", Fiocruz/CFM.

Tabela 4.17 - Médicos distribuídos por tempo de inserção no mercado de trabalho segundo Unidades da Federação. Brasil - 1995

\begin{tabular}{|c|c|c|c|c|c|c|c|c|c|c|c|c|}
\hline \multirow{2}{*}{$\begin{array}{l}\text { Unidades da } \\
\text { Federaçáo }\end{array}$} & \multicolumn{2}{|c|}{ Até 4 anos } & \multicolumn{2}{|c|}{ De 5 a 9 anos } & \multicolumn{2}{|c|}{ De 10 a 24} & \multicolumn{2}{|c|}{ De 25 a 34} & \multicolumn{2}{|c|}{35 e mais } & \multicolumn{2}{|c|}{ TOTAL } \\
\hline & v. abs. & $(\%)$ & v. abs. & $(\%)$ & v. abs. & $(\%)$ & v. abs. & $(\%)$ & v. abs. & $(\%)$ & v. abs. & $(\%)$ \\
\hline REGIÄO NORTE & 470 & 2,1 & 837 & 2,7 & 3.329 & 3,6 & 684 & 3,2 & 378 & 2,4 & 5.698 & 3,1 \\
\hline Amapá & 18 & 0,1 & 19 & 0,1 & 145 & 0,2 & 17 & 0,1 & 8 & 0,1 & 207 & 0,1 \\
\hline Amazonas & 72 & 0,3 & 216 & 0,7 & 912 & 1,0 & 112 & 0,5 & 24 & 0,2 & 1.336 & 0,7 \\
\hline Acre & 12 & 0,1 & 33 & 0,1 & 121 & 0,1 & 26 & 0,1 & 11 & 0,1 & 203 & 0,1 \\
\hline Pará & 289 & 1,3 & 340 & 1,1 & 1.445 & 1,6 & 425 & 2,0 & 323 & 2,1 & 2.822 & 1,5 \\
\hline Rondônia & 22 & 0,1 & 62 & 0,2 & 368 & 0,4 & 48 & 0,2 & 2 & 0,0 & 502 & 0,3 \\
\hline Roraima & 22 & 0,1 & 25 & 0,1 & 86 & 0,1 & 11 & 0,1 & 0 & 0,0 & 144 & 0,1 \\
\hline Tocantins & 35 & 0,2 & 142 & 0,5 & 252 & 0,3 & 45 & 0,2 & 10 & 0,1 & 484 & 0,3 \\
\hline REGIÄO NORDESTE & 2.981 & 13,3 & 4.241 & 13,7 & 16.106 & 17,4 & 3.935 & 18,5 & 1.986 & 12,6 & 29.249 & 16,0 \\
\hline Alagoas & 184 & 0,8 & 395 & 1,3 & 1.399 & 1,5 & 217 & 1,0 & 88 & 0,6 & 2.283 & 1,2 \\
\hline Bahia & 1.076 & 4,8 & 1.157 & 3,7 & 4.681 & 5,0 & 1.127 & 5,3 & 684 & 4,3 & 8.725 & 4,8 \\
\hline Ceará & 377 & 1,7 & 635 & 2,1 & 1.858 & 2,0 & 560 & 2,6 & 261 & 1,7 & 3.691 & 2,0 \\
\hline Maranhāo & 154 & 0,7 & 242 & 0,8 & 1.128 & 1,2 & 282 & 1,3 & 96 & 0,6 & 1.902 & 1,0 \\
\hline Paraíba & 238 & 1,1 & 450 & 1,5 & 1.766 & 1,9 & 398 & 1,9 & 116 & 0,7 & 2.968 & 1,6 \\
\hline Pernambuco & 552 & 2,5 & 810 & 2,6 & 2.820 & 3,0 & 942 & 4,4 & 603 & 3,8 & 5.727 & 3,1 \\
\hline Piauí & 119 & 0,5 & 115 & 0,4 & 678 & 0.7 & 98 & 0,5 & 42 & 0,3 & 1.052 & 0,6 \\
\hline Rio C. Norte & 216 & 1,0 & 246 & 0,8 & 988 & 1,1 & 197 & 0,9 & 60 & 0,4 & 1.707 & 0,9 \\
\hline Sergipe & 65 & 0,3 & 191 & 0,6 & 788 & 0,9 & 114 & 0,5 & 36 & 0,2 & 1.194 & 0,7 \\
\hline RECIĀO SUDESTE & 13.872 & 61,7 & 19.021 & 61,6 & 52.202 & 56,3 & 11.379 & 53,5 & 11.091 & 70,5 & 107.565 & 58,8 \\
\hline Espírito Santo & 315 & 1,4 & 557 & 1,8 & 2.129 & 2,3 & 345 & 1,6 & 145 & 0,9 & 3.491 & 1,9 \\
\hline Minas Gerais & 2.714 & 12,1 & 3.432 & 11,1 & 9.339 & 10,1 & 2.069 & 9,7 & 1.403 & 8,9 & 18.957 & 10,4 \\
\hline Rio de Janeiro & 2.818 & 12,5 & 3.762 & 12,2 & 12.768 & 13,8 & 3.210 & 15,1 & 4.455 & 28,3 & 27.013 & 14,8 \\
\hline São Paulo & 8.025 & 35,7 & 11.270 & 36,5 & 27.966 & 30,2 & 5.755 & 27,1 & 5.088 & 32,3 & 58.104 & 31,7 \\
\hline
\end{tabular}


Tabela 4.17 - Médicos distribuídos por tempo de inserção no mercado de trabalho segundo Unidades da Federação. Brasil - 1995 (continuação)

\begin{tabular}{|c|c|c|c|c|c|c|c|c|c|c|c|c|}
\hline \multirow{2}{*}{$\begin{array}{l}\text { Unidades da } \\
\text { Federaçăo }\end{array}$} & \multicolumn{2}{|c|}{ Atê 4 anos } & \multicolumn{2}{|c|}{ De 5 a 9 anos } & \multicolumn{2}{|c|}{ De 10 a 24} & \multicolumn{2}{|c|}{ De 25 a 34} & \multicolumn{2}{|c|}{35 e mais } & \multicolumn{2}{|c|}{ TOTAL. } \\
\hline & v. abs. & $(\%)$ & v. abs. & $(\%)$ & v. abs. & $(\%)$ & v. abs. & $(\%)$ & v. abs. & (\%) & v. abs. & $(\%)$ \\
\hline RECLĀO SUL & 3.601 & 16,0 & 4.849 & 15,7 & 14.543 & 15,7 & 3.585 & 16,9 & 1.530 & 9,7 & 28.108 & 15,4 \\
\hline Paraná & 1.162 & 5,2 & 1.459 & 4,7 & 4.317 & 4,7 & 1.117 & 5,3 & 769 & 4,9 & 8.824 & 4,8 \\
\hline Rio Grande do Sul & 1.954 & 8,7 & 2.579 & 8,4 & 7.747 & 8,4 & 1.949 & 9,2 & 571 & 3,6 & 14.800 & 8,1 \\
\hline Santa Catarina & 485 & 2,2 & 811 & 2,6 & 2.479 & 2,7 & 519 & 2,4 & 190 & 1,2 & 4.484 & 2,4 \\
\hline RECIĀO C.-OESTE & 1.561 & 6,9 & 1.917 & 6,2 & 6.521 & 7,0 & 1.677 & 7,9 & 756 & 4,8 & 12.432 & 6,8 \\
\hline Distrito Federal & 817 & 3,6 & 711 & 2,3 & 2.223 & 2,4 & 687 & 3,2 & 346 & 2,2 & 4.784 & 2,6 \\
\hline Goiás & 447 & 2,0 & 707 & 2,3 & 2.314 & 2,5 & 630 & 3,0 & 253 & 1,6 & 4.351 & 2,6 \\
\hline Mato Crosso & 110 & 0,5 & 208 & 0,7 & 956 & 1,0 & 143 & 0,7 & 42 & 0,3 & 1.459 & 0,8 \\
\hline M. Grosso do Sul & 187 & 0,8 & 291 & 0,9 & 1.028 & 1,1 & 217 & 1,0 & 115 & 0,7 & 1.838 & 1,0 \\
\hline BRASIL & 22.485 & 100,0 & 30.865 & 100,0 & 92.701 & 100,0 & 21.260 & 100,0 & 15.741 & 100,0 & 183.052 & 100,0 \\
\hline
\end{tabular}

Fonte: Pesquisa "Perfil dos Médicos no Brasil", Fiocruz/CFM

Tabela 4.18 - Médicos distribuídos por setor de atuação segundo tempo de inserção no mercado. Brasil - 1995

\begin{tabular}{lcccccccc}
\hline \multirow{2}{*}{$\begin{array}{c}\text { Tempo de inserção } \\
\text { (em anos) }\end{array}$} & \multicolumn{2}{c}{ Público } & \multicolumn{2}{c}{ Privado } & \multicolumn{2}{c}{ Consultório } & \multicolumn{2}{c}{ TOTAL } \\
\cline { 2 - 9 } & v. abs. & $(\%)$ & v. abs. & $(\%)$ & v. abs. & $(\%)$ & v. abs. & $(\%)$ \\
\hline Até 4 & 17.869 & 42.1 & 13.102 & 30,9 & 11.419 & 27,0 & 42.390 & 100,0 \\
De 5 a 9 & 20.958 & 31,7 & 21.882 & 33,1 & 23.233 & 35,2 & 66.073 & 100,0 \\
De 10 a 24 & 69.860 & 34,9 & 55.951 & 27,9 & 74.363 & 37,2 & 200.174 & 100,0 \\
De 25 a 34 & 14.244 & 34,3 & 11.239 & 27,0 & 16.029 & 38,7 & 41.512 & 100,0 \\
35 e mais & 4.583 & 20,3 & 6.288 & 27,9 & 11.616 & 51,8 & 22.487 & 100,0 \\
\hline TOTAL & 127.514 & 34,2 & 108.462 & 29,1 & 136.660 & 36,7 & 372.636 & 100,0 \\
\hline
\end{tabular}

Fonte: Pesquisa "Perfil dos Médicos no Brasil", Fiocruz/CFM. 
Tabela 4.19 - Médicos distribuídos por tempo de inserção no mercado segundo número de atividades. Brasil - 1995

\begin{tabular}{|c|c|c|c|c|c|c|c|c|c|c|c|c|}
\hline \multirow{2}{*}{$\begin{array}{l}\text { Número de } \\
\text { Atividades }\end{array}$} & \multicolumn{2}{|c|}{ Até 4 anos } & \multicolumn{2}{|c|}{5 a 9 anos } & \multicolumn{2}{|c|}{10 a 24 anos } & \multicolumn{2}{|c|}{25 a 34 anos } & \multicolumn{2}{|c|}{$\begin{array}{c}35 \text { anos e } \\
\text { mais }\end{array}$} & \multicolumn{2}{|c|}{ TOTAL } \\
\hline & v. abs. & $(\%)$ & v. abs. & $(\%)$ & v. abs. & $(\%)$ & v. abs. & $(\%)$ & v. abs. & $(\%)$ & v. abs. & $(\%)$ \\
\hline Uma & 4.939 & 22,0 & 3.602 & 11,7 & 12.546 & 13,5 & 4.100 & 19,3 & 5.928 & 37,7 & 31.115 & 16,9 \\
\hline Duas & 6.146 & 27,3 & 7.922 & 25,7 & 25.466 & 27,5 & 6.177 & 29,1 & 4.044 & 25,7 & 49.755 & 27,1 \\
\hline Três & 5.637 & 25,1 & 9.882 & 32,0 & 29.700 & 32,0 & 6.049 & 28,5 & 2.752 & 17,5 & 54.020 & 29,5 \\
\hline Quatro & 3.275 & 14,6 & 5.931 & 19,2 & 16.283 & 17,6 & 2.411 & 11,3 & 501 & 3,2 & 28.401 & 15,5 \\
\hline Mais de quatro & 2.007 & 8,9 & 2.911 & 9,4 & 8.195 & 8,8 & 1.706 & 8,0 & 343 & 2,2 & 15.162 & 8,3 \\
\hline Sem atividade & 481 & 2,1 & 617 & 2,0 & $5+1$ & 0,6 & 817 & 3,8 & 2.173 & 13,7 & 4.599 & 2,7 \\
\hline TOTAL & 22.485 & 100,0 & 30.865 & 100,0 & 92.701 & 100,0 & 21.260 & 100,0 & 15.741 & 100,0 & 183.052 & 100,0 \\
\hline
\end{tabular}

Fonte: Pesquisa "Perfil dos Médicos no Brasil", Fiocruz/CFM.

Tabela 4.20 - Médicos distribuídos por tempo de inserção no mercado segundo faixas de renda.* Brasil - 1995

\begin{tabular}{|c|c|c|c|c|c|c|c|c|c|c|c|c|}
\hline \multirow{2}{*}{$\begin{array}{c}\text { Faixas de renda } \\
\text { (em dólares) }\end{array}$} & \multicolumn{2}{|c|}{ Até 4 anos } & \multicolumn{2}{|c|}{5 a 9 anos } & \multicolumn{2}{|c|}{10 a 24 anos } & \multicolumn{2}{|c|}{25 a 34 anos } & \multicolumn{2}{|c|}{$\begin{array}{c}35 \text { anos e } \\
\text { mais }\end{array}$} & \multicolumn{2}{|c|}{ TOTAL } \\
\hline & v. abs. & $(\%)$ & v. abs. & (\%) & v. abs. & $(\%)$ & v. abs. & $(\%)$ & v. abs. & $(\%)$ & v. abs. & $(\%)$ \\
\hline Até 500 & 1.746 & 34,5 & 1.337 & 26,4 & 1.217 & 24,0 & 232 & 4,6 & 528 & 10,5 & 5.060 & 100,0 \\
\hline De 501 a 1.000 & 7.520 & 35,2 & 4.983 & 23,4 & 6.724 & 31,5 & 1,149 & 5.4 & 956 & 4,5 & 21.332 & 100,0 \\
\hline De 1.001 a 2.000 & 8.091 & 15,9 & 10.264 & 20,2 & 25.900 & 50,9 & 4.213 & 8,3 & 2.344 & 4,7 & 50.812 & 100,0 \\
\hline De 2.001 a 4.000 & 3.653 & 5,9 & 9.788 & 15,8 & 34.842 & 56,3 & 8.426 & 13,6 & 5.121 & 8,4 & 61.830 & 100,0 \\
\hline De 4.001 a 8.000 & 522 & 1,9 & 2.848 & 10,3 & 17.916 & 64,9 & 4.217 & 15,3 & 2.061 & 7,6 & 27.564 & 100,0 \\
\hline Mais de 8.000 & - & - & 684 & 12,7 & 3.230 & 59,8 & 1.079 & 20,0 & 401 & 7.5 & 5.394 & 100,0 \\
\hline Ignorada** & 953 & 8,6 & 961 & 8,7 & 2.872 & 25,9 & 1.944 & 17,6 & 4.330 & 39,2 & 11.060 & 100,0 \\
\hline TOTAL & 22.485 & 12,3 & 30.865 & 16,9 & 92.701 & 50,6 & 21.260 & 11,6 & 15.741 & 8,6 & 183.052 & 100,0 \\
\hline
\end{tabular}

* Os valores modais (em dólares) por tempo de inserçāo no mercado são: até 4 anos $(786,1)$; de 5 a 9 anos (1.053,6); de 10-24 anos (1.595,9); de $25-34$ anos $(2.133,2) ; 35$ anos e mais $(2.192,4)$.

** Estāo incluídos neste item 4.599 médicos que nāo possuem atividades.

Fonte: Pesquisa "Perfil dos Médicos no Brasil", Fiocruz/CFM.

\section{OS ESPECIALISTAS: UMA QUESTÃO GERACIONAL}

Das 65 especialidades formalmente reconhecidas pelo Conselho Federal de Medicina, as relativas às quatro áreas básicas aqui também referidas como 'matrizes' - pediatria, gineco-obstetrícia, cirurgia geral e medicina interna - absorvem 70.940 $(38,8 \%)$ do total de 183.052 médicos em todo o País (Tabela 4.21). Juntamente com a anestesiologia, a cardiologia, a oftalmologia, a ortopedia e traumatologia, e a psiquiatria, formam o maior contingente de especialistas, com 108.810 médicos. 
A análise dos dados referentes às especialidades por regiōes geográficas revela que há dois grupos distintos de especialistas: o primeiro é formado por médicos que atuam em especialidades básicas ou matrizes, as quais mantêm comportamento homogêneo em todas as regiões, ou seja, há uma proporcionalidade entre o número de médicos existente na região e o número de especialistas em particular. $O$ segundo grupo é constituído por uma típica concentração de especialidades em determinadas regiōes do País, formando verdadeiros nichos de mercado com serviços especializados. Neste segundo bloco, pode-se dizer que se configuram as especialidades do Brasil-Sudeste: cirurgia de mão, cirurgia cardiovascular, cirurgia de cabeça e pescoço, cirurgia pediátrica etc. É possível, assim, considerar a região Sudeste como o mercado dos cirurgiōes-especialistas e dos nichos de especialidades ainda pouco difundidas: sexologia, genética clínica, medicina do tráfego, entre outras. Assim como já afirmamos que o Brasil é feito de pediatras, cirurgiões-gerais, clínicos e ginecoobstetras, podemos também afirmar que o Brasil-Sudeste é composto de cirurgiões especializados, sendo o berço das novas especialidades (Tabela 4.22).

Tabela 4.21 - Médicos distribuídos por grandes regiōes segundo especialidade principal de atuaçăo. Brasil - 1995

\begin{tabular}{|c|c|c|c|c|c|c|}
\hline \multirow{2}{*}{ Especialidades } & \multicolumn{5}{|c|}{ Grandes Regiões } & \multirow{2}{*}{ BRASIL } \\
\hline & Norte & Nordeste & Sudeste & Sul & C.-Oeste & \\
\hline Administração hospitalar & 121 & 417 & 885 & 53 & 81 & 1.557 \\
\hline Alergia e Imunoterapia & 21 & 73 & 285 & 82 & 37 & 498 \\
\hline Anestesiologia & 288 & 1.265 & 5.870 & 1.423 & 727 & 9.573 \\
\hline Angiologia & 25 & 203 & 197 & 22 & 25 & 472 \\
\hline Broncoesofagologia & 2 & 53 & 350 & 83 & 0 & 488 \\
\hline Cancerologia & 19 & 248 & 825 & 386 & 81 & 1.559 \\
\hline Cardiologia & 147 & 1.141 & 5.793 & 1.165 & 613 & 8.859 \\
\hline Cirurgia cabeça e pescoço & 35 & 46 & 542 & 63 & 54 & 740 \\
\hline Cirurgia cardiovascular & 52 & 175 & 1.086 & 169 & 43 & 1.525 \\
\hline Cirurgia geral & 357 & 1.758 & 5.280 & 1.747 & 907 & 10.049 \\
\hline Cirurgia de mão & 16 & 128 & 462 & 5 & 8 & 619 \\
\hline Citopatologia & 0 & 249 & 276 & 91 & 43 & 659 \\
\hline Cirurgia pediátrica & 64 & 302 & 1.665 & 282 & 106 & 2.419 \\
\hline Cirurgia plástica & 94 & 361 & 2.283 & 476 & 181 & 3.395 \\
\hline Cirurgia torácica & 33 & 233 & 342 & $130^{\circ}$ & 40 & 778 \\
\hline Cirurgia vascular & 48 & 392 & 1.254 & 395 & 197 & 2.286 \\
\hline Dermatologia & 188 & 604 & 1.965 & 585 & 148 & 3.490 \\
\hline Eletroencefalografia & 59 & 107 & 674 & 161 & 23 & 1.024 \\
\hline
\end{tabular}


Tabela 4.21 : Médicos distribuídos por gæandes regióes segundo especialidade principal de atuação. Brasil - 1995 (continuaçăo)

\begin{tabular}{|c|c|c|c|c|c|c|c|}
\hline \multirow{2}{*}{ Especialidades } & & \multicolumn{5}{|c|}{ Grandes Regiōes } & \multirow{2}{*}{ BRASIL } \\
\hline & & Norte: & Nordeste & Sudeste & Sul & C.-Oeste & \\
\hline \multicolumn{2}{|c|}{ Endocrinologia e Metabolia } & 27 . & 288 & 1.350 & 233 & 156 & 2.054 \\
\hline \multicolumn{2}{|l|}{ Endoscopia digestiva } & $\therefore 38$ & 111 & 355 & 167 & 45 . & $\therefore \therefore 716$ \\
\hline \multicolumn{2}{|l|}{ Foniatria* } & 0 & $\mathbf{0}$ & 0 & 0 & $\mathbf{0}$ & $\therefore 0$ \\
\hline \multicolumn{2}{|l|}{ Fisiatria } & 0 & 12 & 371 & 84 & 32 & 499 \\
\hline \multicolumn{2}{|l|}{ Gastroenterologia } & $\therefore 47$ & 291 & 1.533 & 282 & $124:$ & $2: 277$ \\
\hline \multicolumn{2}{|l|}{ Cenética clínica } & 0 & 0 & 108 & 5 & 11 & $\therefore \quad 124$ \\
\hline \multicolumn{2}{|c|}{ Geriatria e Gerontologia } & 0 & 103 & 162 & 93 & 20 & $\because=378$ \\
\hline \multicolumn{2}{|l|}{ Gineco-Obstetrícia } & 694 & 3.532 & 12.457 & 3.230 & 1.662 & $: 21: 575$ \\
\hline \multicolumn{2}{|l|}{ Hansenologia } & 11 & 10 & 87 & 0 & 25 & $\because 133$ \\
\hline \multicolumn{2}{|l|}{ Hematologia } & 36 & .219 & 612 & 137 & 37 & $\therefore 1: 041$ \\
\hline \multicolumn{2}{|l|}{ Hemoterapia } & $\therefore 0$ & 86 & 317 & 31 & 4 & $\because 438$ \\
\hline \multicolumn{2}{|l|}{ Homeopatia } & 17 & 145 & 1.904 & 222 & 140 & 2.428 \\
\hline \multicolumn{2}{|l|}{ Infectologia } & 126 & 120 & 832 & 124 & 47 & .1249 \\
\hline \multicolumn{2}{|l|}{ Mastologia } & 0 & 88 & 86 & 39 & 0 & 213 \\
\hline \multicolumn{2}{|l|}{ Medicina do trabalho } & 87 & 454 & 3.046 & $\therefore, 597$ & 143 & 4.327 \\
\hline \multicolumn{2}{|l|}{ Medicina do tráfego } & 3 & 0 & 237 & 4 & 20 & 264 \\
\hline \multicolumn{2}{|l|}{ Medicina esportiva } & 0 & 0 & 214 & 5 & 0 & 219 \\
\hline \multicolumn{2}{|l|}{ Medicina interna } & 481 & 2.781 & 7.375 & 2.739 & 1.290 & 14.666 \\
\hline \multicolumn{2}{|l|}{ Medicina legal } & 71 & 91 & 84 & $\therefore 94$ & $\therefore \because$ & $\therefore \quad: 378$. \\
\hline \multicolumn{2}{|l|}{ Medicina nuclear. } & $\therefore 0$ & $\therefore 58$ & $\therefore 0$ & $\therefore 9$ & 16 & 83 \\
\hline \multicolumn{2}{|l|}{ Medicina sanitária. } & 150 & $\therefore 540$ & 910 . & 309 & 105 & 2.014 \\
\hline \multicolumn{2}{|c|}{ Medicina geral comunitária } & 393 & 947 & …039 & 1.009 & $\therefore 424$ & 4.812 \\
\hline \multicolumn{2}{|l|}{ Nefrologia } & 22 & 314 & -719 & 554 & 90 & 1.699 \\
\hline \multicolumn{2}{|l|}{ Neurocirurgia } & 27 & 80 & 1.093 & 228 & 59 & 1.487 \\
\hline Neurofisiologia & & 0 & 51 & 37 & $56^{\prime}$ & 0 & 144 \\
\hline Neurologia & & 33 & 223 & 1.345 & 194 & 98 & 1.893 \\
\hline Neurologia pediátrica & & 18. & 102 & 382 & 258 & 37 & 797 \\
\hline Nutrologia & & 3 & 10 & 75 & 32 & 0 & 120 \\
\hline Oftalmologia & & 179 & 1.086 & 4.018 & 835 & 382 & 6.500 \\
\hline Ortopedia e Traumatc & ologia & 153 & 895 & 4.423 & 886 & 457 & 6.814 \\
\hline Otorrinolaringologia & & 65 & 272 & 1.827 & 535 & 226 & 2.925 \\
\hline Patologia & & 41 & 150 & 968 & 120 & 113 & 1.392 \\
\hline Patologia clínica & & 91 & 175 & 618 & 50 & 64 & 998 \\
\hline
\end{tabular}


Tabela 4.21 - Médicos distribuídos por grandes regiōes segundo especialidade principal de atuação. Brasil - 1995 (continuação)

\begin{tabular}{|c|c|c|c|c|c|c|}
\hline \multirow{2}{*}{ Especialidades } & \multicolumn{5}{|c|}{ Grandes Regiōes } & \multirow{2}{*}{ BRASIL } \\
\hline & Norte & Nordeste & Sudeste & Sul & C.-Oeste & \\
\hline Pediatria & 739 & 4.163 & 14.143 & 3.647 & 1.958 & 24.650 \\
\hline Pneumologia & 132 & 490 & 692 & 251 & 59 & 1.624 \\
\hline Proctologia & 19 & 107 & 329 & 58 & 83 & 596 \\
\hline Psiquiatria & 106 & 1.114 & 3.164 & 1.549 & 191 & 6.124 \\
\hline Radiologia & 24 & 578 & 2.334 & 508 & 230 & 3.674 \\
\hline Radioterapia & 0 & 52 & 190 & 77 & 33 & 352 \\
\hline Reumatologia & 21 & 125 & 757 & 146 & 63 & 1.112 \\
\hline Sexologia & 0 & 0 & 7 & 0 & 0 & 7 \\
\hline Terapia intensiva & 16 & 205 & 1.202 & 104 & 143 & 1.670 \\
\hline Tisiologia & 3 & 0 & 159 & 0 & 17 & 179 \\
\hline Urologia & 83 & 257 & 1.483 & 429 & 154 & 2.406 \\
\hline Outras & 12 & 211 & 372 & 117 & 29 & 741 \\
\hline Ignorada & 161 & 958 & 3.115 & 743 & 293 & 5.270 \\
\hline TOTAL & 5.698 & 29.249 & 107.565 & 28.108 & 12.432 & 183.052 \\
\hline
\end{tabular}

* Na amostra não houve a seleção de foniatras.

Fonte: Pesquisa "Perfil dos Médicos no Brasil", Ficcruz/CFM.

Tabela 4.22 - Médicos distribuídos por grandes regióes segundo especialidade principal de atuação (percentuais por linha). Brasil - 1995

\begin{tabular}{lcccccc}
\hline \multirow{2}{*}{ Especialidades } & \multicolumn{7}{c}{ Grandes Regióes } & \multirow{2}{*}{ BRASIL } \\
\cline { 2 - 6 } & Norte & Nordeste & Sudeste & \multicolumn{1}{c}{ Sul } & C.-Oeste \\
\hline Administraçăo hospitalar & 7,8 & 26,8 & 56,8 & 3,4 & 5,2 & 100,0 \\
Alergia e Imunoterapia & 4,2 & 14,7 & 57,2 & 16,5 & 7,4 & 100,0 \\
Anestesiologia & 3,0 & 13,2 & 61,3 & 14,9 & 7,6 & 100,0 \\
Angiologia & 5,3 & 43,0 & 41,7 & 4,7 & 5,3 & 100,0 \\
Broncoesofagologia & 0,4 & 10,9 & 71,7 & 17,0 & 0,0 & 100,0 \\
Cancerologia & 1,2 & 15,9 & 52,9 & 24,8 & 5,2 & 100,0 \\
Cardiologia & 1,7 & 12,9 & 65,4 & 13,2 & 6,9 & 100,0 \\
Cirurgia cabeça e pescoço & 4,7 & 6,2 & 73,2 & 8,5 & 7,3 & 100,0 \\
Cirurgia cardiovascular & 3,4 & 11,5 & 71,2 & 11,1 & 2,8 & 100,0 \\
Cirurgia geral & 3,6 & 17,5 & 52,5 & 17,4 & 9,0 & 100,0 \\
Cirurgia de mão & 2,6 & 20,7 & 74,6 & 0,8 & 1,3 & 100,0
\end{tabular}


Tabela 4.22 - Médicos distribuídos por grandes regiōes segundo especialidade principal de atuaçăo (percentuais por linha). Brasil - 1995 (continuaçăo)

\begin{tabular}{|c|c|c|c|c|c|c|}
\hline \multirow{2}{*}{ Especialidades } & \multicolumn{5}{|c|}{ Grandes Regiōes } & \multirow{2}{*}{ BRASIL } \\
\hline & Norte & Nordeste & Sudeste & Sul & C.-Oeste & \\
\hline Citopatologia & 0,0 & 37,8 & 41,9 & 13,8 & 6,5 & 100,0 \\
\hline Cirurgia pediátrica & 2,6 & 12,5 & 68,8 & 11,7 & 4,4 & 100,0 \\
\hline Cirurgia plástica & 2,8 & 10,6 & 67,2 & 14,0 & 5,3 & 100,0 \\
\hline Cirurgia torácica & 4,2 & 29,9 & 44,0 & 16,7 & 5,1 & 100,0 \\
\hline Cirurgia vascular & 2,1 & 17,1 & 54,9 & 17,3 & 8,6 & 100,0 \\
\hline Dermatologia & 5,4 & 17,3 & 56,3 & 16,8 & 4,2 & 100,0 \\
\hline Eletroencefalografia & 5,8 & 10,4 & 65,8 & 15,7 & 2,2 & 100,0 \\
\hline Endocrinologia e Metabolia & 1,3 & 14,0 & 65,7 & 11,3 & 7,6 & 100,0 \\
\hline Endoscopia digestiva & 5,3 & 15,5 & 49,6 & 23,3 & 6,3 & 100,0 \\
\hline Foniatria* & - & - & - & - & - & - \\
\hline Fisiatria & 0,0 & 2,4 & 74,3 & 16,8 & 6,4 & 100,0 \\
\hline Gastroenterologia & 2,1 & 12,8 & 67,3 & 12,4 & 5,4 & 100,0 \\
\hline Genética clínica & 0,0 & 0,0 & 87,1 & 4,0 & 8,9 & 100,0 \\
\hline Geriatria e Gerontologia & 0,0 & 27,2 & 42,9 & 24,6 & 5,3 & 100,0 \\
\hline Gineco-Obstetrícia & 3,2 & 16,4 & 57,7 & 15,0 & 7,7 & 100,0 \\
\hline Hansenologia & 8,3 & 7,5 & 65,4 & 0,0 & 18,8 & 100,0 \\
\hline Hematologia & 3,5 & 21,0 & 58,8 & 13,2 & 3,6 & 100,0 \\
\hline Hemoterapia & 0,0 & 19,6 & 72,4 & 7,1 & 0,9 & 100,0 \\
\hline Homeopatia & 0,7 & 6,0 & 78,4 & 9,1 & 5,8 & 100,0 \\
\hline Infectologia & 10,1 & 9,6 & 66,6 & 9,9 & 3,8 & 100,0 \\
\hline Mastologia & 0,0 & 41,3 & 40,4 & 18,3 & 0,0 & 100,0 \\
\hline Medicina do trabalho & 2,0 & 10,5 & 70,4 & 13,8 & 3,3 & 100,0 \\
\hline Medicina do tráfego & 1,1 & 0,0 & 89,8 & 1,5 & 7,6 & 100,0 \\
\hline Medicina esportiva & 0,0 & 0,0 & 97,7 & 2,3 & 0,0 & 100,0 \\
\hline Medicina interna & 3,3 & 19,0 & 50,3 & 18,7 & 8,8 & 100,0 \\
\hline Medicina legal & 18,8 & 24,1 & 22,2 & 24,9 & 10,1 & 100,0 \\
\hline Medicina nuclear & 0,0 & 69,9 & 0,0 & 10,8 & 19,3 & 100,0 \\
\hline Medicina sanitária & 7,4 & 26,8 & 45,2 & 15,3 & 5,2 & 100,0 \\
\hline Medicina geral comunitária & 8,2 & 19,7 & 42,4 & 21,0 & 8,8 & 100,0 \\
\hline Nefrologia & 1,3 & 18,5 & 42,3 & 32,6 & 5,3 & 100,0 \\
\hline Neurocirurgia & 1,8 & 5,4 & 73,5 & 15,3 & 4,0 & 100,0 \\
\hline Neurofisiologia & 0,0 & 35,4 & 25,7 & 38,9 & 0,0 & 100,0 \\
\hline
\end{tabular}


Tabela 4.22 - Médicos distribuídos por grandes regióes segundo especialidade principal de atuação (percentuais por linha). : Brasil - 1995 (continuaçăo)

\begin{tabular}{|c|c|c|c|c|c|c|c|}
\hline \multirow{2}{*}{ Especialidades- } & & \multicolumn{5}{|c|}{ Grandes Regiōes } & \multirow{2}{*}{ BRASIL } \\
\hline & & Norte & Nordeste & Sudeste : & Sul & C.-Oeste & \\
\hline Neurologia & . & 1,7 & 11,8 & 71,1 & 10,2 & 5,2 & 100,0 \\
\hline Neurologia pediátrica & & $2,3 . i$ & 12,8 & 47,9 & 32,4 & 4,6 & 100,0 \\
\hline Nutrologia & $\ldots$ & 2,5 & 8,3 & 62,5 & 26,7 & 0,0 & 100,0 \\
\hline Oftalmologia & $\therefore$ & 2,8 & 16,7 & 61,8 & 12,8 & 5,9 & 100,0 \\
\hline Ortopedia e Traumatol & logia & 2,2 & 13,1 & 64,9 . & 13,0 & 6,7 & 100,0 \\
\hline Otorrinolaringologia & & 2,2 & 9,3 & 62,5 & 18,3 & 7,7 & 100,0 \\
\hline Patologia & & 2,9 & 10,8 & 69,5 & 8,6 & $8 ; 1$ & 100,0 \\
\hline Patologia clínica & & 9,1 & 17,5 & 61,9 & $5 ; 0$ & 6,4 & 100,0 \\
\hline Pediatria & & 3,0 & 16,9 & 57,4 & 14,8 & 7,9 & 100,0 \\
\hline Pneumologia & & 8,1 & 30,2 & 42,6 & 15,5 & 3,6 & 100,0 \\
\hline Proctologia & . & 3,2 & 18,0 & 55,2 & 9,7 & 13,9 & 100,0 \\
\hline Psiquiatria & $\cdot$ & 1,7 & 18,2 & 51,7 & 25,3 & 3,1 & 100,0 \\
\hline Radiologia & . & 0,7 & 15,7 & 63,5 & 13,8 & 6,3 & 100,0 \\
\hline Radioterapia & . & 0,0 & 14,8 & 54,0 & 21,9 & 9,4 & $.100,0$ \\
\hline Reumatologia & . & 1,9 & 11,2 & 68,1 & 13,1 & 5,7 & $\therefore 100,0$ \\
\hline Sexologia & : & 0,0 & 0,0 & 100,0 & 0,0 & 0,0 & 100,0 \\
\hline Terapia intensiva & $\because$ & 1,0 & 12,3 & 72,0 & 6,2 & 8,6 & 100,0 \\
\hline Tisiologia & & 1,7 & 0,0 & 88,8 & 0,0 & 9,5 & $100 ; 0$ \\
\hline Urologia & & 3,4 & $10 ; 7$ & 61,6 & 17,8 & 6,4 & 100,0 \\
\hline Outras & & 1,6 & 28,5 & 50,2 & 15,8 & 3,9 & $\therefore 100,0$ \\
\hline Ignorada & & 3,1 & 18,2 & 59,1 & 14,1 & 5,6 & 100,0 \\
\hline TOTAL & .. & 3,1 & 16,0 & 58,8 & 15,4 & 6,8 & $.100,0$ \\
\hline
\end{tabular}

* Na amostra não houve a seleção de foniatras.

Fonte: Pesquisa "Perfil dos Médicos no Brasil", Fiocruz/CFM.

Além disso, o mercado de serviços conta com um contingente de médicos que, suplementarmente; atuam em nichos superespecializados (nao-reconhecidos pelo Conselho Federal de Medicina), captando clientela altamente selecionada: $O$ Quadro 4.1 mostra a variedade encontrada, $\mathrm{e}$, certamente, existem inúmeras outras que a pesquisa não pôde detectar. Essas subespecialidades são, em boa parte, subconjuntos da cirurgia especializada (cirurgia do aparelho digestivo, cirurgia experimental etc.) e da área de imagens e diagnóstico (ultra-sonografia, ultra-sonografia vascular, ecografia, videoendoscopia etc.). Chama-nos a atenção o comportamento 
dos pediatras, que, constituindo-se ém área de assistência de um ontingente populacional específico (infantil), acaba criando subáreas 'quase autônomas' de atuação. na área médica. Estas, por suâ interface cóm outras especialidádes cognitivas típicas do adulto, têm estado no centro de repetidas controvérsias a respeito de șua matriz de formação básica. No caso das subespecialidades técnicas (cirurgia, oftalmologia etc.), estas tendem a ser reconhecidas como a matriz básica do conhecimento e, conseqüentemente, da formaçăo.

Ainda que a distribuiçáo dos médicos que atuam nas especialidades básicas $\mathbf{e}$ na anestesiologia seja regular para todas as gerações, tal fato não oєorre com as demais. Estas especialidades demonstraram um movimento específico a cada faixa etária, configurando-se em 'gerações de médicos especialistas'. Tal tendência, certamente, é influenciada por aspectos de mercado, fato que corrobora a tese de que os médicos são filhos de seu tempo, sem lugar para romantismos ou idealizáçổès teóricas. Esses aspectos podem ser identificados como: a) decorrentes das transformações epidemiológicas observadas no País; b) decorrentes do modelo de assistência médico-sanitária implantado; c) secundários à incorporação tecnológica observada na medicina e à atração efetiva que ela exerce sobre os profissionais e d) secundários à organização político-ldeológica das diversas especialidades diante das questôes de ordem médica.

A distribuição das especialidades segundo a faixa etária requer precaução e cuidados metodológicos na análise. Como visto em çapítulos anteriores, o maior contingente de médicos encontra-se na faixa de 35 a 44 anos, conseqüência da criação de escolas médicas nó final da década de 60 e início da de 70 , refletindo um boom desses profissionaîs, cuja maior expressãó foi verificada no início dos anos 80 . Ao construir o Quadro 4.2, percebemos com certa clareza a força deste fenômeno 'geracional'.

A análise das especialidades segundo geraçöes exigiria, a rigor, um estudo longitudinal que permitisse acompanhar, por um período, as 'escolhas profissionais' dos médicos. Utilizando os dadós da pesquisa e pará aprésentar uma primeira aproximação a este respeito, procuramos nos deter na análise da frequêência de profissionais de cada especialidade segundo geraçóes. 
Quadro 4.1 - Subespecialidades declaradas.* Brasil - 1995

\begin{tabular}{|l|l|}
\hline Anatomia, Anatomia humana & Medicina de seguro \\
Andrologia & Medicina escolar \\
Antroposofia & Medicina ortomolecular \\
Arritmias cardíacas & Medicina tropical \\
Cardiologia pediátrica & Microbiologia \\
Cirurgia do aparelho digestivo & Microbiologia médica \\
Cirurgia experimental & Nefrologia pediátrica \\
Colposcopia & Neonatologia \\
Ecocardiologia & Neuroradiologia \\
Ecografia & Perícia médica \\
Ergonomia & Perinatologia \\
Farmacologia & Psicanálise \\
Farmacologia endócrina & Psicanálise e Psicologia social \\
Fitoterapia & Psicobiologia \\
Hemodinâmica & Psicodinâmica \\
Histologia e embriologia & Radiologia pediátrica \\
Imunologia renal & Reproduçăo humana \\
Imunologia clínica pediátrica & Terapia intensiva pediátrica \\
Laparoscopia & Toxicologia \\
Lingüística educacional & Ultra-sonografia \\
Mamografia & Ultra-sonografia vascular \\
Medicina estética e Cosmetologia & Videoendoscopia \\
Medicina aeroespacial & \\
\hline
\end{tabular}

* Áreas de atuação especializada do médico, independente de ser ou não ligada à medicina ou reconhecida pelo CFM.

Fonte: Pesquisa "Perfil dos Médicos no Brasil", Fiocruz/CFM. 
Quadro 4.2 - Comportamento geracional de especialidades selecionadas segundo posição relativa na década.* Brasil - 1995

\begin{tabular}{|c|c|c|c|c|c|c|}
\hline $\begin{array}{l}\text { Especialidades } \\
\text { selecionadas }\end{array}$ & Anos 40 & Anos 50 & Anos 60 & Anos 70 & Anos 80 & Anos 90** \\
\hline \multicolumn{7}{|c|}{ Cognitivas } \\
\hline Cardiologia & 11 & 13 & 10 & 7 & 4 & 5 \\
\hline Endocrinologia e Metabolia & 21 & 38 & 24 & 24 & 18 & 24 \\
\hline Homeopatia & 0 & 32 & 23 & 19 & 14 & 27 \\
\hline Infectologia & 0 & 34 & 19 & 36 & 27 & 30 \\
\hline Med. geral e comunitária & 1 & 15 & 9 & 10 & 17 & 12 \\
\hline Medicina do trabalho & 24 & 5 & 8 & 11 & 15 & 15 \\
\hline Medicina interna & 3 & 6 & 3 & 3 & 3 & 2 \\
\hline Neurologia & 0 & 21 & 35 & 16 & 30 & 17 \\
\hline Pediatria & 4 & 2 & 1 & 1 & 1 & 1 \\
\hline Pneumologia & 23 & 18 & 46 & 23 & 25 & 19 \\
\hline Psiquiatria & 18 & 10 & 7 & 6 & 9 & 13 \\
\hline \multicolumn{7}{|c|}{ Técnico-cirúrgicas } \\
\hline Cirurgia cardiovascular & 14 & 30 & 28 & 25 & 28 & 28 \\
\hline Cirurgia geral & 5 & 3 & 4 & 5 & 6 & 4 \\
\hline Cirurgia pediátrica & 0 & 31 & 26 & 15 & 21 & 16 \\
\hline Cirurgia plástica & 7 & 12 & 17 & 17 & 11 & 32 \\
\hline Cirurgia toráxica & 0 & 42 & 20 & 40 & 35 & 47 \\
\hline Cirurgia vascular & 22 & 20 & 15 & 21 & 37 & 9 \\
\hline \multicolumn{7}{|c|}{ Intermediárias } \\
\hline Anestesiologia & 6 & 4 & 5 & 4 & 5 & 6 \\
\hline Broncoesofagologia & 8 & 40 & 47 & 56 & 48 & 44 \\
\hline Cancerologia & 0 & 17 & 33 & 30 & 29 & 14 \\
\hline Dermatologia & 10 & 24 & 14 & 14 & 12 & 11 \\
\hline Fisiatria & 0 & 29 & 16 & 50 & 57 & 0 \\
\hline Gastroenterologia & 12 & 23 & 27 & 18 & 20 & 21 \\
\hline Gineco-Obstetrícia & 2 & 1 & 2 & 2 & 2 & 3 \\
\hline Oftalmologia & 0 & 11 & 12 & 8 & 8 & 7 \\
\hline Ortopedia e Traumatologia & 0 & 7 & 6 & 9 & 7 & 8 \\
\hline Otorrinolaringologia & 19 & 9 & 18 & 22 & 13 & 20 \\
\hline Terapia intensiva & 0 & 0 & 0 & 29 & 16 & 33 \\
\hline Urołogia & 16 & 16 & 11 & 27 & 19 & 18 \\
\hline \multicolumn{7}{|c|}{ Tecnológicas e Burocráticas } \\
\hline Administração hospitalar & 25 & 14 & 22 & 20 & 36 & 42 \\
\hline Eletroencefalografia & 9 & 19 & 29 & 32 & 45 & 39 \\
\hline Hemoterapia & 13 & 0 & 39 & 53 & 42 & 0 \\
\hline Medicina sanitária & 27 & 28 & 32 & 13 & 23 & 49 \\
\hline Patologia & 15 & 8 & 30 & 33 & 39 & 38 \\
\hline Patologia clínica & 17 & 22 & 13 & 41 & 40 & 46 \\
\hline Radiologia & 20 & 27 & 31 & 12 & 10 & 10 \\
\hline
\end{tabular}

* Posição que a especialidade ocupava em ordem de procura pelos médicos na respectiva década.

- As décadas consideradas na tabela seguem a tipologia criada no Quadro 1.2 (Cap. 1) que associa a geraçāo dos médicos formados com a respectiva faixa etária.

Fonte: Pesquisa "Perfil dos Médicos no Brasil", Fiocruz/CFM. 
Vamros 'desprezar' metodologicamente as áreas: (especialidades) matrizes de nossa análise geracional, por térem demonstrado comportamento linear em todas as geraçóes aqui estudadas (das décadas de 40 a 90 ). Assim, temos o seguinte quadro gèracional:

a) anos 40: médicos comunitaristas, broncoesofagologistas, eletroencefalografistas, gastroenterologistas e hemoterapeutas;

b) anos 50: anestesistas, patologistas, otorrinolaringologistas, médicos do trabalho e ortopedistas e traumatologistas;

c) anos 60: anestesistas, otorrinolaringologistas, psiquiatras, médicos do trabalho e ortopedistas e traumatologistas;

d) anos 70: anestesistas, cardiologistas, psiquiatras, oftalmologistas e ortopedistas e traumatologistas.;

e) anos 80: cardiologistas, cirurgiôes plásticos, oftalmologistas, ortopedistas e traumatologistas e intensivistas; $\mathrm{e}$

f) "anos 90: cardiologistas, cirurgióes vasculares, oftalmọlogistas, ortopedistas e traumatologistas e cancerologistas.

Gráfico 4.2 - Movimento geracional das especialidades. Brasil - 1995

Evoluçăo da participaçào dos grupos

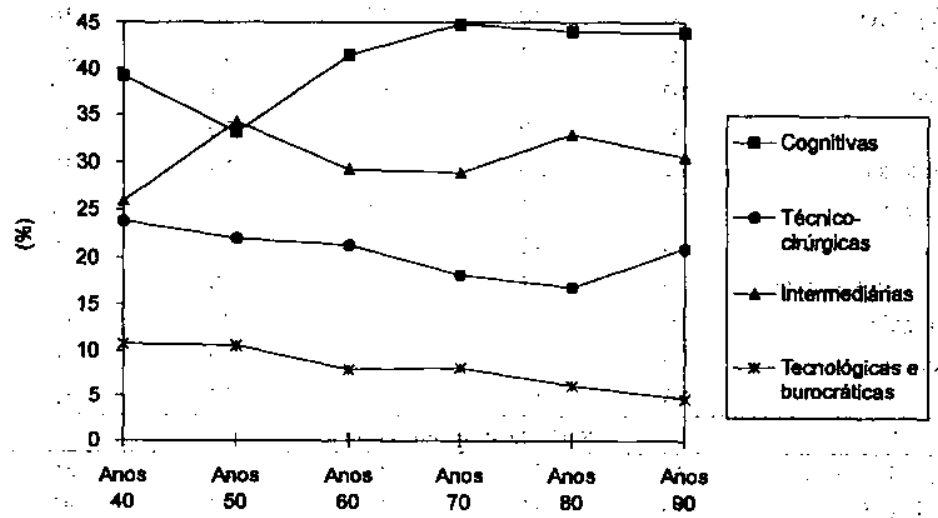

Fonte: Pesquisa "Perfil dos Médicos no Brasil", Fiocruz/CFM. 


\section{DEFININDO O PERFIL DAS ESPECIALIDADES MATRIZES}

\section{Os clinicos gerais}

A medicina interna, hoje reconhecida e considerada como uma especialidade, foi, durante muito tempo - enquanto persistia a divisão entre físicos e cirurgiōes - a essência cognitiva da medicina. Com a intensifiçaçăo da divisăo técnica do trabalhọ, diversas especialidades clínicas nasceram de seu campo de conhecimento. Com 14.666 clínicos, representa $8,0 \%$ do total de médicos do País $(59,9 \%$ nas capitais e $39,1 \%$ no interior). A maioria dos clínicos $(68,5 \%)$ formou-se em escolas públicas e fez residência $(60,2 \%)$ (Quadro 4.3). A clínica médica é uma especialidade tipicamente masculina, com forte atuação no setor público. Em sua quase totalidade, săo profissionais que possuem menos de três atividades, com renda média de 2.247 dólares.

\section{Os cirurgiōes-gerais}

Até o advento da medicina científica, esta prática era pouco valorizada e, como a própria clínica, marcada pelo insucesso e despreștígio. A descoberta da anestesia e da assepsia valorizou-a socialmente, levando-a a superar as restrições e o preconceito que a marcavam enquanto prática eminentemente técnica. $\mathrm{O}$ moderno desenvolvimento tecnológico e a ininterrupta incorporaçăo deste à prática de saúde têm possibilitado um fantástico desenvolvimento de téçnicas cirúrgicas e do êxito de sua prática e, também, têm contribuído para o florescimento de inúmeras subespecialidades cirúrgicas de grande habilidade e prestígio. Pode-se dizer que a cirurgia, de modo geral, é hoje uma prática médica de enorme sucesso social e financeiro.

Estes especialistas estāo também distribuídos de forma regular em nível nacional, em todas as faixas etárias. Freqüentar um ano de residência médica nesta especialidade é pré-requisito para a especialização na maioria das outras áreas cirúrgicas típicas, o que contribui para que um grande volume de médicos recém-formados esteja fazendo residência. Sabe-se, no entanto, que boa parte dos atuais residentes, tanto da medicina interna como da cirurgia, não atuarão nessas áreas, mas em especialidades correlatas a elas. Sua distribuição geográfica é bem equilibrada, tanto nas grandes regiōes, como nas capitais e no interior. Os cirurgiōes, em sua maioria, também são originários de escolas públicas e boa parte deles tem residência, especial. mente aqueles que atuam nas capitais (77\%). Os cirurgiōes sāo homens, com atuação nos três setores e com renda mensal média de 3.008 dólares (Quadro 4.3). 


\section{Os pediatras}

Os pediatras totalizam 24.650 profissionais, formando o maior contingente de médicos especialistas do País (13,5\%), estando distribuídos de forma homogênea em todo o território brasileiro. Em sua maioria $(63,5 \%)$, são formados em escolas públicas. Do total de pediatras, $78,7 \%$ freqüentaram residência médica. Em relação ao mercado de trabalho, mais da metade tem entre 10 e 24 anos de profissão, exercendo em média três atividades, com maior atuação no setor público. É uma especialidade tendencialmente feminina, com uma renda média de 2.163 dólares (Quadro 4.3).

\section{Os Gineco-Obstetras ${ }^{7}$}

Da mesma forma que os pediatras, os gineco-obstetras constituem uma das especialidades que concentram maior número de médicos no País - 21.575 $(11,8 \%)$, com distribuição eqüitativa em todas as Unidades da Federação. São formados na rede pública de ensino (64\%) e estão homogeneamente distribuídos em diversas faixas etárias. Os que residem nas capitais - como era de se esperar, por se tratar de um mercado mais competitivo - destacam-se nos aspectos de formação, ou seja, $78 \%$ fizeram pelo menos uma residência médica e $52 \%$, duas ou mais. Os gineco-obstetras, em sua maioria, são homens, atuam com mais intensidade nos consultórios e exercem, em média, três atividades, com uma renda média de 2.824 dólares (Quadro 4.3).

7 Por serem especialidades correlatas, quase sempre desenvolvidas de forma complementar e simultânea pelo médico, optamos por analisá-las conjuntamente. 


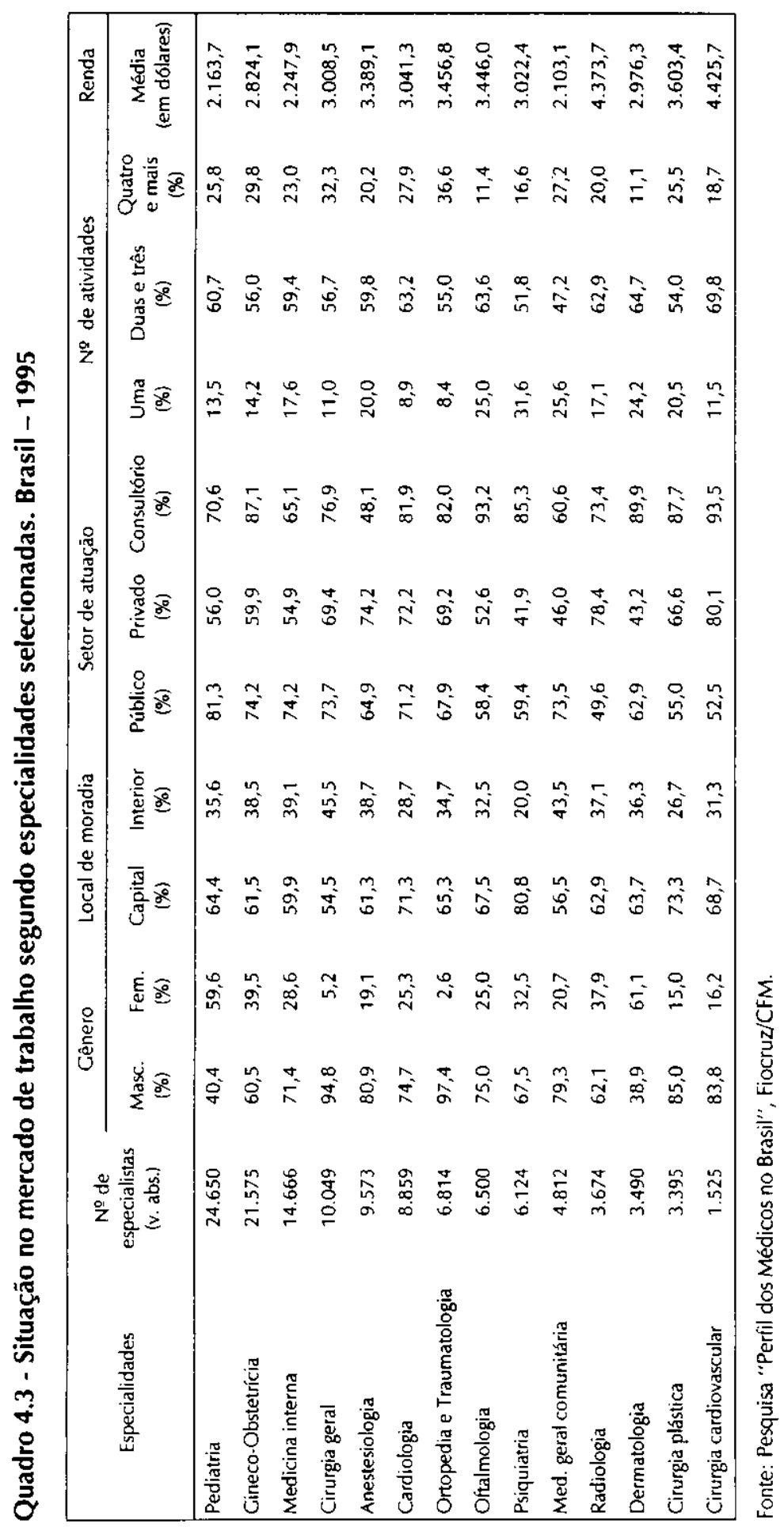


Quadro 4.4 - As dez principais especialidades distribứtas por Unidades da Federaçầo em ordem decrescentê. Brasil - 1995

\begin{tabular}{|l|l|}
\hline BRASIL & $\begin{array}{l}\text { Pediatria, Gineco-Obstetrícia, Medicina interna, Cirurgia geral, } \\
\text { Anestesiologia, Cardiologia, Ortopedia e Tráumatologia, } \\
\text { Oftalmologia, Psiquiatria e Medicina geral comúnitária. }\end{array}$ \\
\hline
\end{tabular}

\begin{tabular}{|c|c|}
\hline REGIÃO NORTE & $\begin{array}{l}\text { Pediatria, Gineco-Obstetrícia, Medicina interna, Medicina geral } \\
\text { comunitária, Cirurgia geral, Arestesiologia, Dermatologia, } \\
\text { Oftalmologia, Ortopedia e Traumatologia e Medicina sanitária. }\end{array}$ \\
\hline Acre & $\begin{array}{l}\text { Pediatria, Medicina geral comunitária, Gineco-Obstetrícia, Medicina } \\
\text { interna, Cirurgia geral, Anestesiologia, Oftalmologia, } \\
\text { Otorrinolaringologia, Infectologia e Cardiológia. }\end{array}$ \\
\hline Amapá & $\begin{array}{l}\text { Pediatria, Medicina interna, Anestesiologia, Ortopedia e } \\
\text { Traumatologia, Medicina geral comunitária, Gineco-Obstetrícia, } \\
\text { Cirurgia geral, Terapia intensiva, Neurologia e Cardiologia. }\end{array}$ \\
\hline Amazonas & $\begin{array}{l}\text { Pediatria, Gineco-Obstetrícia, Medicina interna, Medicina geral } \\
\text { comunitária, Anestesiologia, Oftalmologia, Cirurgia geral, Medicina } \\
\text { sanitária, Dermatologia e Medicina do trabalho. }\end{array}$ \\
\hline Pará & $\begin{array}{l}\text { Pediatra, Gineco-Obstetrícia, Medicina interna, Cirurgia getal, } \\
\text { Medicina geral comunitária, Anestesiologia, Dermatologia, } \\
\text { Pneumologia, Infectologia e Patologia clínica. }\end{array}$ \\
\hline Rondônia & $\begin{array}{l}\text { Gineco-Obstetrícia, Pediatria, Medicina interna, Cirurgia geral, } \\
\text { Medicina geral comunitária, Cardiologia, Anestesiologia, } \\
\text { Oftalmologia, Ortopedia e Traumatologia e Medicina sanitária. }\end{array}$ \\
\hline Roraima & $\begin{array}{l}\text { Gineco-Obstetrícia, Medicina geral comunitária, Anestesiologia, } \\
\text { Medicina interna, Medicina legal, Cirurgia geral, Ortopedia e } \\
\text { Traumatologia, Cardiologia, Radiologia e Pediatria. }\end{array}$ \\
\hline Tocantins & $\begin{array}{l}\text { Medicina geral comunitária, Cineco-Obstetrícia, Medicina interna, } \\
\text { Cirurgia geral, Pediatria, Ortopedia e Traumatologia, Oftalmologia, } \\
\text { Anestesiologia e Otorrinolaringologia. }\end{array}$ \\
\hline
\end{tabular}

\begin{tabular}{|l|l|}
\hline $\begin{array}{l}\text { RECIÄO } \\
\text { NOROESTE }\end{array}$ & $\begin{array}{l}\text { Pediatria, Cineco-Obstetrícia, Medicina interna, Cirurgia geral, } \\
\text { Anestesiologia, Cardiologia, Psiquiatria, Oftalmologia, Medicina geral } \\
\text { comunitária, Ortopedia e Traumatologia. }\end{array}$ \\
\hline Alagoas & $\begin{array}{l}\text { Pediatria, Cineco-Öbstetrícia, Medicina interna, Anestesiologia, } \\
\text { Medicina geral comunitária, Psiquiatria, Cirurgia geral, Ortopedia e } \\
\text { Traumatologia, Oftalmologia e Cardiologia. }\end{array}$ \\
\hline Bahia & $\begin{array}{l}\text { Gineco-Obstetrícia, Medicina interna, Pediatria, Cirurgia geral, } \\
\text { Cardiologia, Psiquiatria, Oftalmologia, Ortopedia e Traumatologia, } \\
\text { Anestesiologia e Medicina geral comunitária. }\end{array}$ \\
\hline Ceará & $\begin{array}{l}\text { Cineco-Obstetrícia, Pediatria, Oftalmologia, Anestesiologia, Medicina } \\
\text { interna, Cardiologia, Cirurgia geral, Pneumologia, Medicina geral } \\
\text { comunitária e Girungia plástica. }\end{array}$ \\
\hline
\end{tabular}


Quadro 4.4 As dez principais especialidades distribúdas por Unidades da

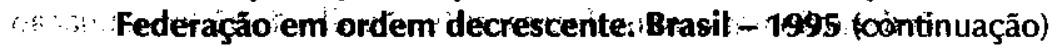

\begin{tabular}{|c|c|}
\hline \begin{tabular}{c} 
Maranhäo \\
\hdashline$:$ \\
\hdashline
\end{tabular} & $\begin{array}{l}\text { Pediatria, Gineco-Obstetrícia, Cirurgia geral, Medicina interna, } \\
\text { Mediçina geral comuniţária, Anestesiologia, Oftalmologia, Ortopedia } \\
\text { e Traumatọlogia, Mediçna. Sanitária e Dermatologia. }\end{array}$ \\
\hline $\begin{array}{c}\text { Paraíba } \\
\cdots\end{array}$ & $\begin{array}{l}\text { Pediatria, Gineco-Obstetrícia, Medicina interna, Anestesiologia } \\
\text { Cirurgia geral, Medicina geral comunitária, Cardiologia, Ortopedia e } \\
\text { Traumatologia, Psiquiatria e Cirurgia torácica. }\end{array}$ \\
\hline Pernambuco & $\begin{array}{l}\text { Pediatria, Medjcina interna, Gineco-Obstetrícia, Cirurgia geral } \\
\text { Anestesjologia . Psiqujatria, Cirurgia vascular, Cardiologia, } \\
\text { Citopatologia e Radiologia.: }\end{array}$ \\
\hline 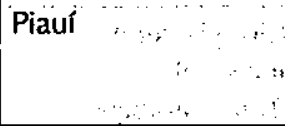 & $\begin{array}{l}\text { Gineco-Qbstetrícia, Pediatria, Cirurgia geral, Medicina interna, } \\
\text { Médicina geral comunitária, Psiquiatria, Dermatologia, Oftalmologia, } \\
\text { Cardiologia e Radiologạa }\end{array}$ \\
\hline $\begin{array}{l}\text { Rio Grande do } \\
\text { Norte }\end{array}$ & $\begin{array}{l}\text { Gineco-Obstetrícia, Pediatria, Cirurgia geral, Medicina interna, } \\
\text { Medicina geral comunitária, Psiquiatria, Oftalmologia, Medicina } \\
\text { sanitária, Dermátologia e Anestésiologià. }\end{array}$ \\
\hline Sergipe & $\begin{array}{l}\text { Pediatria, Medicina interna, Gineco-Obstetrícia, Anestesiologia, } \\
\text { Medicina geral comunitária, Cardiologia, Psiguiatria, Radiotogia, } \\
\text { Oftalmólogia e Cirurgia geral. }\end{array}$ \\
\hline
\end{tabular}

\begin{tabular}{|c|c|}
\hline $\begin{array}{l}\text { REGIÄQ SUPESTE } \\
\therefore \quad \therefore \quad \therefore \quad \therefore \quad\end{array}$ & $\begin{array}{l}\text { Pediatria, Gineco-Obstetricia, Medicina interna, Anestesiologia, } \\
\text { Cardiologia Cirurgia geral, Ortopedia e Traumatologia, Oftalmologia, } \\
\text { Psiquiatria e Medicina do trabalho. }\end{array}$ \\
\hline Espírito Santo & $\begin{array}{l}\text { Pediatria, Gineco-Obstetrícia, Medicina interna, Cirurgia geral, } \\
\text { Anestesiologia, Ortopedia e Traumatologia, Oftalmologia, } \\
\text { Cardiologia, Dermatologia e Psiquiatria. }\end{array}$ \\
\hline $\begin{array}{r}\text { Minas Gerais } \\
\therefore\end{array}$ & $\begin{array}{l}\text { Pediatria, Gineco-Öbstetricia, Medicina interna, Crurgia geral, } \\
\text { Cardiologia, Anestessiologia, Oftalmologia, Ortopedia e } \\
\text { Traumatologia, Medicina geral comunitária e Medicina do trabalho. }\end{array}$ \\
\hline Rio de Janeiro & $\begin{array}{l}\text { Pediatria, Gineco-Obstetrícia, Anestesiologia, Cardiologia, Medicina } \\
\text { interna, Cirurgia geral, Ortopedia e Traumatologia, Psiquiatria, } \\
\text { Oftalmologia e Cirurgia plástica. }\end{array}$ \\
\hline São Paulo & $\begin{array}{l}\text { Pediatria, Gineco-Obstetrícia, Medicina interna, Cardiologia, } \\
\text { Anestesiologia, Ortopedia e Traumatologia, Cirurgia geral, } \\
\text { Oftalmologia, Psiquiatria e Medicina do trabalho. }\end{array}$ \\
\hline
\end{tabular}


Quadro 4.4 - As dez principais especialidades distribuídas por Unidades da Federação em ordem decrescente. Brasil - 1995 (continuação)

\begin{tabular}{|l|l|}
\hline REGIÄO SUL & $\begin{array}{l}\text { Pediatria, Gineco-Obstetrícia, Medicina interna, Cirurgia geral, } \\
\text { Psiquiatria, Anestesiologia, Cardiologia, Medicina geral comunitária, } \\
\text { Ortopedia e Traumatologia e Oftalmologia. }\end{array}$ \\
\hline Paraná & $\begin{array}{l}\text { Pediatria, Gineco-Obstetrícia, Medicina interna, Cirurgia geral, } \\
\text { Anestesiologia, Cardiologia, Oftalmologia, Psiquiatria, Medicina do } \\
\text { trabalho e Cirurgia vascular. }\end{array}$ \\
\hline Rio Grande do Sul & $\begin{array}{l}\text { Gineco-Obstetrícia, Pediatria, Medicina interna, Psiquiatria, Cirurgia } \\
\text { geral, Anestesiologia, Medicina geral comunitária, Ortopedia e } \\
\text { Traumatologia, Cardiologia e Nefrologia. }\end{array}$ \\
\hline Santa Catarina & $\begin{array}{l}\text { Pediatria, Medicina interna, Gineco-Obstetrícia, Cirurgia geral, } \\
\text { Oftalmologia, Cardiologia, Anestesiologia, Medicina geral } \\
\text { comunitária, Medicina do trabalho, Ortopedia e Traumatologia. }\end{array}$ \\
\hline
\end{tabular}

\begin{tabular}{|l|l|}
\hline REGIĀO & $\begin{array}{l}\text { Pediatria, Gineco-Obstetrícia, Medicina interna, Cirurgia geral, } \\
\text { Anestesiologia, Cardiologia, Ortopedia e Traumatologia, Medicina } \\
\text { geral comunitária, Oftalmologia e Radiologia. }\end{array}$ \\
\hline Distrito Federal & $\begin{array}{l}\text { Pediatria, Medicina interna, Gineco-Obstetrícia, Cardiologia, } \\
\text { Anestesiologia, Cirurgia geral, Oftalmologia, Ortopedia e } \\
\text { Traumatologia, Otorrinoralingologia e Medicina geral comunitária. }\end{array}$ \\
\hline Goiás & $\begin{array}{l}\text { Pediatria, Gineco-Obstetrícia, Cirungia geral, Medicina interna, } \\
\text { Anestesiologia, Medicina geral comunitária, Cardiologia, Ortopedia e } \\
\text { Traumatologia, Oftalmologia e Radiologia. }\end{array}$ \\
\hline Mato Grosso & $\begin{array}{l}\text { Pediatria, Gineco-Obstetrícia, Medicina interna, Cirurgia geral, } \\
\text { Anestesiologia, Cardiologia, Oftalmologia, Medicina geral } \\
\text { comunitária, Ortopedia e Traumatologia e Cirurgia vascular. }\end{array}$ \\
\hline Mato Grosso do Sul & $\begin{array}{l}\text { Pediatria, Gineco-Obstetrícia, Cirurgia geral, Ortopedia e } \\
\text { Traumatologia, Medicina interna, Anestesiologia, Cardiologia, } \\
\text { Oftamologia, Medicina geral comunitária e Homeopatia. }\end{array}$ \\
\hline
\end{tabular}

Fonte: Pesquisa "Perfil dos Médicos no Brasil", Fiocruz/CFM. 
Quadro 4.5 - Especialidades segundo faixa de rendimento. Brasil - 1995

\begin{tabular}{|l|l|}
\hline $\begin{array}{c}\text { Faixas de rendimento } \\
\text { (em dólares) }\end{array}$ & \multicolumn{1}{|c|}{ Especialidades } \\
\hline Mais de 5.000 & Radioterapia; Medicina nuclear e Neurofisiologia clínica. \\
\hline De 4.000 a 4.999 & $\begin{array}{l}\text { Hansenologia; Endoscopia digestiva; Mastologia; Cirurgia } \\
\text { cardiovascular e Radiologia. }\end{array}$ \\
\hline De 3.000 a 3.999 & $\begin{array}{l}\text { Proctologia; Otorrinolaringologia; Patologia; Cirurgia plástica; } \\
\text { Hematologia; Ortopedia e Traumatologia; Oftalmologia; Urologia; } \\
\text { Anestesiologia; Alergia e Imunoterapia; Cirurgia de cabeça e } \\
\text { pescoço; Cirurgia vascular; Neurocirurgia; Angiologia; } \\
\text { Endocrinologia e Metabolia; Cardiologia; Psiquiatria; } \\
\text { Gastroenterologia; Patologia clínica; Cirurgia geral e Medicina } \\
\text { esportiva. }\end{array}$ \\
\hline De 2.000 a 2.999 & $\begin{array}{l}\text { Cirurgia pediátrica; Dermatologia; Geriatria e Gerontologia; } \\
\text { Terapia Intensiva; Fisiatria; Cirurgia torácica; Nutrologia; } \\
\text { Gineco-Obstetrícia; Nefrologia; Hemoterapia; Homeopatia; } \\
\text { Medicina do trabalho; Broncoesofagologia; Neurologia; } \\
\text { Reumatologia; Infectologia; Administração hospitalar; } \\
\text { Cancerologia; Neurologia pediátrica; Cirurgia da mão; } \\
\text { Pneumologia; Eletroencefalografia; Medicina interna; Pediatria; } \\
\text { Medicina geral comunitária; Medicina de tráfego; Medicina legal e } \\
\text { Citopatologia. }\end{array}$ \\
\hline Menos de 1.999 & \begin{tabular}{l} 
Medicina sanitária; Sexologia; Tisiologia e Genética clínica. \\
\hline
\end{tabular} \\
\hline
\end{tabular}

Fonte: Pesquisa "Perfil dos Médicos no Brasil", Fiocruz/CFM.

Quadro 4.6 - Renda média segundo especialidades. Brasil - 1995

\begin{tabular}{|l|c|}
\hline \multicolumn{1}{|c|}{$\begin{array}{c}\text { Especialidade } \\
\text { principal }\end{array}$} & $\begin{array}{c}\text { Renda média } \\
\text { (em dólares) }\end{array}$ \\
\hline Endoscopia digestiva & $4.518,9$ \\
Cirurgia cardiovascular & $4.425,7$ \\
Radiologia & $4.373,7$ \\
Proctologia & $3.718,5$ \\
Otorrinolaringologia & $3.677,8$ \\
Patologia & $3.612,7$ \\
Cirurgia plástica & $3.603,4$ \\
Hematologia & $3.581,0$ \\
Ortopedia e Traumatologia & $3.456,8$ \\
Oftalmologia & $3.446,0$ \\
Urologia & $3.428,8$ \\
Anestesiologia & $3.389,1$ \\
Cirurgia cardiovascular & $3.256,4$ \\
Cirurgia vascular & $3.199,8$
\end{tabular}


Quadro 4.6 - Renda média por especialidades. Brasil - 1995 (continuação)

\begin{tabular}{|l|c|}
\hline \multicolumn{1}{|c|}{$\begin{array}{c}\text { Especialidade } \\
\text { principal }\end{array}$} & $\begin{array}{c}\text { Renda média } \\
\text { (em dólares) }\end{array}$ \\
\hline Neurocirurgia & $3.198,7$ \\
Endocrinologia e Metabolia & $3.056,9$ \\
Cardiologia & $3.041,3$ \\
Psiquiatria & $3.022,4$ \\
Castroenterologia & $3.013,8$ \\
Patologia clínica & $3.009,8$ \\
Cirurgia geral & $3.008,5$ \\
Cirurgia pediátrica & $2.981,0$ \\
Dermatologia & $2.976,3$ \\
Terapia intensiva & $2.890,0$ \\
Cirurgia torácica & $2.838,0$ \\
Gineco-Obstetrícia & $2.824,1$ \\
Nefrologia & $2.760,6$ \\
Homeopatia & $2.599,2$ \\
Medicina do trabalho & $2.597,6$ \\
Neurologia & $2.570,9$ \\
Reumatologia & $2.528,8$ \\
Infectologia & $2.520,1$ \\
Administração hospitalar & $2.488,0$ \\
Cancerologia & $2.439,1$ \\
Neurologia pediátrica & $2.405,6$ \\
Cirurgia de mão & $2.349,8$ \\
Pneumologia & $2.302,4$ \\
Eletroencefalografia & $2.266,4$ \\
Medicina interna & $2.247,9$ \\
Pediatria & $2.163,7$ \\
Medicina geral comunitária & $2.103,1$ \\
Citopatologia & $2.038,6$ \\
Medicina sanitária & $1.917,6$ \\
Outras* & $3.217,3$ \\
\hline
\end{tabular}

* Inclui todas as especialidades com menos de 500 médicos.

Fonte: Pesquisa "Perfil dos Médicos no Brasil", Fiocruz/CFM. 


\section{AS MÉDICAS NO BRASIL}

\section{A INSERÇÃO DAS MULHERES NO MUNDO DO TRABALHO}

O mundo contemporâneo assiste à inserção da mulher no mercado de trabaIho como nunca antes visto. Este fenômeno foi acentuado, em parte, pela necessidade de suprimento de măo-de-obra requisitado pelo avanço industrial, sobretudo no período de vigência das duas grandes guerras e na época subseqüente a elas, quando o capitalismo experimentou grande crescimento econômico. Vaitsman (1989:37) mostra que 0

aprofundamento da acumulação capitalista - que se fez por meio do desenvolvimento sem par das forças materiais de produção e da sociedade de consumo -, a elevação do nivel educacional e de informação das massas - através da expansão do ensino e das novas técnicas de comunicação - e de urbanizaçāo foram alguns dos fatores decisivos para provocar as transformações na divisão sexual do trabalho típicas do início do capitalismo industrial. As mulheres começaram a participar de forma cada vez mais legítima de um espaço antes reservado apenas aos individuos do gênero masculino, nas atividades profissionais, educacionais, politicas etc. Paralelamente, o avanço da ciência garantiu o domínio de técnicas cada vez mais eficazes de controle da fertilidade, permitindo que elas se tornassem capazes de domesticar sua natureza biológica. Esse processo, típico dos países capitalistas mais modernos - isto é, mais industrializados e mais democráticos - implicou o desenvolvimento não só de uma consciência feminista por parte de um número crescente de mulheres, mas também de formas de açōes politicas canalizadoras de suas reivindicaçōes especificas, fazendo com que a luta pela ampliação dos direitos de cidadania fosse assumida também como luta pelos direitos femininos.

Aliada a essas mudanças estritamente econômicas, fez-se presente uma nova concepção do papel feminino na sociedade, na qual as mutheres vêm conquistando maior representatividade social. Isto ocorre em todos os setores de atividades, in- 
cluindo profissōes de reconhecido prestígio social, como a medicina, a odontologia, a engenharia e a advocacia, entre outras. Tal fato pode ser explicado, em parte, pelo crescimento do ensino superior em todo o mundo, resultando em maior acesso das mulheres às universidades, levando ao que se denominou 'processo de feminilização'. De fato,

o aumento da escolaridade feminina tem permitido maiores oportunidades de ingresso da mulher em ocupaçōes e postos especializados, influenciando o incremento da taxa de atividade feminina nas idades jovens (a partir dos 18 anos) e mais maduras. (Médici, 1989:79)

No Brasil, por exemplo, a participação feminina tem crescido mais, proporcionalmente, nos segmentos de mulheres com nivel de escolaridade mais elevado.

Os dados da Pesquisa Nacional por Amostra de Domićlios indicam, ainda, que a escolaridade é determinante na elevação dos niveis de participação econômica da mulher. Em 1985 a taxa de atividade feminina foi de 62,06\% para as mulheres com nove ou mais anos de estudo e de apenas 36,55\% nas mulheres com cinco a oito anos de estudo. (Médici, 1989:80)

Enfim, o que se tem registrado é que

quanto maior a escolaridade alcançada pelas mulheres, maiores têm sido suas oportunidades concretas de inserçāo na força de trabalho. Desta forma, 26,0\% das mulheres economicamente ativas detêm nove anos de estudo ou mais, contra apenas 16,9\% dos homens nesta condiçāo. (Médici, 1989:80)

No entanto, essa participaçăo das mulheres no mundo do trabalho, na esfera pública, freqüentemente está associada a atividades de baixo prestígio, que gravitam em torno de atividades econômicas ligadas às funções do setor terciário (funções de doméstica, limpeza, higiene) ou às áreas sociais, como nutrição, educação e saúde, todas elas localizadas no setor de prestação de serviços. Assinala Médici (1989:83):

Em termos gerais, as mulheres respondiam, em 1985, por $33,3 \%$ do total de ocupados. No entanto, em dois ramos de atividades as mulheres sāo maioria absoluta. Cerca de $65 \%$ dos ocupados no setor de prestaçāo de serviços são mulheres, o mesmo ocorrendo nas atividades sociais, onde a participação feminina é de $73 \%$.

Mesmo inseridas numa estrutura pouco vantajosa, as mulheres têm adquirido espaço cada vez mais evidente.

Uma das mais rápidas transformaçōes na conjuntura do mercado de trabalho dos últimos vinte anos diz respeito ao aumento da participação da muIher. Entre 1976 e 1985 a taxa de atividade feminina passa de $28,7 \%$ para $36,9 \%$. Neste período o contingente de mulheres economicamente ativas cresceu a uma taxa geométrica anual de $5,6 \%$, enquanto o contingente masculino cresceu, apenas, 2,9\%. (Médici, 1989:78-79) 


\section{AS MÉDICAS NO MERCADO DE TRABALHO}

O mundo do trabalho médico é, por tradição, constituído por profissionais do sexo masculino, seja nos países industrializados e com tradição democrata, como Estados Unidos, França e Alemanha, seja naqueles que compóem a realidade latinoamericana, como Argentina, Chile e Brasil. Só muito recentemente se assistiu à entrada de mulheres nesse mercado para exercer o ofício de curar. No Brasil, o fenômeno da feminilização só vai ocorrer a partir do final dos anos 30, mesmo assim de forma acanhada, tomando impulso apenas nas décadas seguintes.

Tratando-se especificamente da medicina no Brasil, os números corroboram o que se disse acima, apontando uma crescente participação de mulheres na profissão (Tabela 5.1). A consolidação da măo-de-obra feminina na profissão médica é fruto da geração dos anos 70 . Tal situação resulta das transformações ocorridas naquela época, quando as mulheres buscaram inserir-se na vida econômica produtiva do País, seja em áreas de baixa qualificação, como a prestaçāo de serviços - limpeza, vestuário etc. -, seja nos serviços de alta qualificação, como engenharia, advocacia, medicina, matemática, física e arquitetura, entre outros. Se, nos anos 90, registra-se quase a metade do contingente médico (com menos de 30 anos) constituído por mulheres, mostrando sua nítida posição de destaque, nos anos 40 elas não passavam de $1 \%$. A evolução do processo de feminilização demonstra que a participação da mulher experimentou um acentuado e vigoroso crescimento nestes últimos cinqüenta anos (Tabela 5.1).

Tabela 5.1 - Evolução da participação das mulheres distribuída por décadas segundo grandes regióes. ${ }^{*}$ Brasil - 1995

\begin{tabular}{|c|c|c|c|c|c|c|c|c|c|c|c|c|}
\hline \multirow{2}{*}{$\begin{array}{c}\text { Brasil e Grandes } \\
\text { Regiōes }\end{array}$} & \multicolumn{2}{|c|}{ Anos 40} & \multicolumn{2}{|c|}{ Anos 50} & \multicolumn{2}{|c|}{ Anos 60} & \multicolumn{2}{|c|}{ Anos 70} & \multicolumn{2}{|c|}{ Anos 80} & \multicolumn{2}{|c|}{ Anos 90} \\
\hline & v. abs. & $(\%)$ & v. abs. & $(\%)$ & v. abs. & $(\%)$ & v. abs. & (\%) & v. abs. & $(\%)$ & v. abs. & $(\%)$ \\
\hline Norte & 0 & 0,0 & 2 & 0,7 & 147 & 21,5 & 728 & 30,5 & 832 & 46,7 & 226 & 48,1 \\
\hline Nordeste & 22 & 4,7 & 332 & 21,9 & 880 & 22,4 & 4.077 & 38,7 & 5.104 & 52,1 & 1.610 & 54,0 \\
\hline Sudeste & 12 & 0,3 & 826 & 12,7 & 1.662 & 14,6 & 9.227 & 27,8 & 16.308 & 42,9 & 6.874 & 49,6 \\
\hline Sul & 19 & 4,9 & 12 & 6,3 & 344 & 3,6 & 2.046 & 21,3 & 3.514 & 35,8 & 1.554 & 43,2 \\
\hline Centro-Oest & 0 & 0,0 & 48 & 8,0 & 242 & 14,4 & 1.035 & 23,6 & 1.458 & 35,9 & 698 & 44,7 \\
\hline BRASIL-TOTAL & 53 & 1,0 & 1.280 & 12,3 & 3.275 & 15,4 & 17.113 & 28,6 & 27.216 & 42.9 & 10.962 & 48,8 \\
\hline BRASIL-Capitais & 43 & 1,0 & 1.146 & 15,5 & 2.666 & 18,9 & 12.988 & 34,4 & 19.341 & 47,5 & 8.223 & 50,5 \\
\hline BRASIL-Interiores & 10 & 1,0 & 134 & 4,5 & 609 & 8,5 & 4.125 & 18,4 & 7.875 & 34,7 & 2.739 & 44,2 \\
\hline
\end{tabular}

* As décadas consideradas seguem a tipologia criada no Quadro 1.2 (Cap. 1), que associa a geração dos médicos formados com a respectiva faixa etária.

Fonte: Pesquisa "Perfil dos Médicos no Brasil", Fiocruz/CFM. 
Os dados da pesquisa sobre as capitais e o interior do País indicam que esse crescimento foi ainda mais acentuado nos grandes centros urbanos (nas capitais), fato explicado, em parte, pelo maior dinamismo econômico-social e pelas transformações culturais ocorridas - como o movimento feminista e o movimento pela cidadania, entre outros.

Enfocando a análise pelo ângulo das grandes regiōes brasileiras, notam-se variações em torno da média nacional, sendo a região Sudeste $(32,5 \%)$ a que melhor acompanha a tendência nacional (Tabela 5.2). Chama a atenção o índice de feminilização da região Nordeste, que atinge $41,1 \%$, especialmente se comparado aos do Sul $(26,9 \%)$ e Centro-Oeste (28,0\%). Ressalta-se a baixa participação feminina em alguns estados, se comparada à média nacional: Acre $(22,2 \%)$, Rondônia $(22,7 \%)$, Santa Catarina $(22,7 \%)$, Goiás $(21,2 \%)$ e Mato Grosso $(22,1 \%)$. É importante registrar que nestes estados, exceto em Santa Catarina, as condiçōes de vida da população são difíceis, dada a situaçāo de início de desenvolvimento regional. Sendo assim, a inserção da mulher nestas regiōes, de modo geral, torna-se ainda mais difícil, exigindo maior esforço diante de condições sócio-culturais e econômicas muito desfavoráveis.

O mercado de trabalho médico dispôe hoje de um contingente de aproximadamente duzentos mil médicos, dos quais em torno de $30 \%$ são mulheres. Os números revelam que as médicas estão inseridas no mercado com características semelhantes às de seus colegas médicos (Quadro 5.1). Poucas são as variaçōes nas modalidades de inserçăo do contingente feminino. O que mais se destaca talvez seja a maior participação delas nos empregos da esfera pública $(75,1 \%$ contra $67,0 \%)$ e uma participação menor na prática em consultório, onde as mulheres mostram índices de $67,0 \%$, e os homens, de $78,4 \%$. Resumindo, os dados sugerem que o contingente feminino trabalha um pouco menos em consultórios, em estabelecimentos privados, faz menos plantão e está mais inserido no mercado de trabalho por meio do emprego público (Quadro 5.1).

\section{Quadro 5.1 - Atuação profissional segundo gênero. Brasil - 1995}

\begin{tabular}{|c|c|c|c|c|}
\hline \multirow{2}{*}{ Gênero } & Público & Privado & Consultório & Plantão \\
\cline { 2 - 5 } & $(\%)$ & $(\%)$ & $(\%)$ & $(\%)$ \\
\hline Masculino & 67,0 & 61,9 & 78,4 & 50,0 \\
\hline Feminino & 75,1 & 53,9 & 67,0 & 46,6 \\
\hline
\end{tabular}

Fonte: Pesquisa "Perfil dos Médicos no Brasil", Fiocruz/CFM.

Um dos fatores que justifica essa preferência institucional é o fato de que nessas instituições, por força constitucional, a inserção no trabalho se dá por vínculo formal (concurso público), assegurando à mulher direitos trabalhistas, como licença maternidade, abono de faltas e férias. Também cabe ressaltar que, por tradição da cultura organizacional, o horário (apesar de formalmente preestabelecido), a produtividade e o controle burocrático săo menores nas instituições públicas, permitindo maior flexibilização das inúmeras exigências sociais impostas à mulher. 
Um dado que corrobora o que se expôs acima é a participaçāo das médicas nas instituiçóes privadas. Pouco mais da metade delas $(53,9 \%)$ desenvolvem atividades no setor privado, o que não ocorre com os médicos. Sabe-se que boa parte dos postos de trabalho oferecidos a estes profissionais constituem uma relação profissional sem vínculo trabalhista e, portanto, sem direitos legais, prescritos na Constituição brasileira.

Tabela 5.2 - Médicos distribuídos por gênero segundo Unidades da Federação. Brasil - 1995

\begin{tabular}{|c|c|c|c|c|c|c|}
\hline \multirow{2}{*}{$\begin{array}{c}\text { Unidades da } \\
\text { Federação }\end{array}$} & \multicolumn{2}{|c|}{ Masculino } & \multicolumn{2}{|c|}{ Feminino } & \multicolumn{2}{|c|}{ TOTAL } \\
\hline & v. abs. & (\%) & v. abs. & (\%) & v. abs. & $(\%)$ \\
\hline Acre & 158 & 77,8 & 45 & 22,2 & 203 & 100,0 \\
\hline Amazonas & 864 & 64,7 & 472 & 35,3 & 1.336 & 100,0 \\
\hline Amapá & 157 & 75,8 & 50 & 24,2 & 207 & 100,0 \\
\hline Pará & 1.734 & 61,4 & 1.088 & 38,6 & 2.822 & 100,0 \\
\hline Rondônia & 388 & 77,3 & 114 & 22,7 & 502 & 100,0 \\
\hline Roraima & 108 & 75,0 & 36 & 25,0 & 144 & 100,0 \\
\hline Tocantins & 354 & 73,1 & 130 & 26,9 & 484 & 100,0 \\
\hline REGIÄO NORTE & 3.763 & 66,0 & $1.93 \overline{5}$ & 34,0 & 5.698 & 100,0 \\
\hline$\overline{\text { Alagoas }}$ & 1.131 & 49,5 & 1.152 & 50,5 & 2.283 & 100,0 \\
\hline Bahia & 5.369 & 61,5 & 3.356 & 38,5 & 8.725 & 100,0 \\
\hline Ceará & 2.261 & 61,3 & 1.430 & 38,7 & 3.691 & 100,0 \\
\hline Maranhão & 1.246 & 65,5 & 656 & 34,5 & 1.902 & 100,0 \\
\hline Paraíba & 1.688 & 56,9 & 1.280 & 43,1 & 2.968 & 100,0 \\
\hline Pernambuco & 3.159 & 55,2 & 2.568 & 44,8 & 5.727 & 100,0 \\
\hline Piaui & 744 & 70,7 & 308 & 29,3 & 1.052 & 100,0 \\
\hline Rio Grande do Norte & 960 & 56,2 & 747 & 43,8 & 1.707 & 100,0 \\
\hline Sergipe & 666 & 55,8 & 528 & 44,2 & 1.194 & 100,0 \\
\hline REGIÄO NORDESTE & 17.224 & 58,9 & 12.025 & 41,1 & 29.249 & 100,0 \\
\hline Espírito Santo & 2.370 & 67,9 & 1.121 & 32,1 & 3.491 & 100,0 \\
\hline Minas Gerais & 13.614 & 71,8 & 5.343 & 28,2 & 18.957 & 100,0 \\
\hline Rio de Janeiro & 16.714 & 61,9 & 10.299 & 38,1 & 27.013 & 100,0 \\
\hline São Paulo & 39.958 & 68,8 & 18.146 & 31,2 & 58.104 & 100,0 \\
\hline REGIÃO SUDESTE & 72.656 & 67,5 & 34.909 & 32,5 & 107.565 & 100,0 \\
\hline Paraná & 6.678 & 75,7 & 2.146 & 24,3 & 8.824 & 100,0 \\
\hline Rio Grande do Sul & 10.416 & 70,4 & 4.384 & 29,6 & 14.800 & 100,0 \\
\hline Santa Catarina & 3.465 & 77,3 & 1.019 & 22,7 & 4.484 & 100,0 \\
\hline REGIÄO SUL & 20.559 & 73,1 & 7.549 & 26,9 & 28.108 & 100,0 \\
\hline Distrito Federal & 3.002 & 62,8 & 1.782 & 37,2 & 4.784 & 100,0 \\
\hline Goiás & 3.428 & 78,8 & 923 & 21,2 & 4.351 & 100,0 \\
\hline Mato Grosso do Sul & 1.384 & 75,3 & 454 & 24,7 & 1.838 & 100,0 \\
\hline Mato Grosso & 1.137 & 77,9 & 322 & 22,1 & 1.459 & 100,0 \\
\hline REGIÃO CENTRO-OESTE & 8.951 & 72,0 & 3.481 & 28,0 & 12.432 & 100,0 \\
\hline BRASIL & 123.153 & 67,3 & 59.899 & 32,7 & 183.052 & 100,0 \\
\hline
\end{tabular}

Fonte: Pesquisa "Perfil dos Médicos no Brasil", Fiocruz/CFM. 
As mulheres atuam menos nas atividades da iniciativa privada: $33 \%$ declararam não ter consultório, embora a maioria delas trabalhe em áreas que requerem atendimento em consultório - pediatria, ginecologia e dermatologia. No total de consultórios existentes no Brasil, a participação feminina é inferior a $\mathbf{3 0 \%}$.

Estariam as mulheres mais afetas às atividades assalariadas? Estariam elas menos afetas à iniciativa privada? Tenderiam mais à estabilidade no emprego?

Segundo os dados empíricos da pesquisa, as mulheres sofrem discriminações sociais, por vezes sutis, por parte dos colegas e da sociedade em geral:

Falta de respeito em cidades do interior. Não indicação para cargos de chefia. (ginecologista, feminino, 31 anos, MG)

Preconceitos nos empregos públicos e/ou privados. A mulher médica precisa mostrar dez vezes mais capacidade de trabalho para ser considerada 'igual' ao sexo masculino. (anestesiologista, feminino, 60 anos, SC)

Abuso do poder dos colegas (nas chefias). Discriminação da mulher pelos próprios colegas. (pediatra, feminino, 34 anos, $\mathrm{RO}$ )

Em relação ao tempo dedicado ao trabalho pela mulher, constata-se que vêm ocorrendo mudanças significativas. Até recentemente afirmava-se que:

Embora números crescentes de mulheres se qualifiquem para o exercício de uma atividade ocupacional, esta qualificação se faz, quase sempre, a título das garantias pessoais que representa no futuro incerto que a ordem social competitiva encerra. O trabalho, como via de realização profissional, como fator de enriquecimento da personalidade humana e mesmo como meio de ajustamento social a condiçóes de variável grau de insegurança econômica, não constitui ainda um valor nem para a maioria das mulheres nem para a sociedade quando atribui ao contingente feminino de seus membros papéis sociais bastante definidos. Ter um emprego significa, para a mulher, encontrar um modo socialmente aceitável de enfrentar uma situação econômica difícil ou de ampliar os rendimentos da família, de maneira a permitir certa folga orçamentária a fim de proporcionar melhor e mais completa educação aos filhos, alcançar um padrăo superior de vida. (Saffioti, 1976:300-301)

Progressivamente, entretanto, vai se desfazendo a noção, por vezes falsa, de que o trabalho e o salário da mulher são complementares aos do homem, uma vez que a vida da mulher na esfera produtiva é cada vez mais intensa e duplamente desgastante. Desse modo, dedicar-se mais ou menos ao trabalho não pode mais ser entendido como uma questão de gênero.

A pesquisa mostra que o percentual de médicas que exercem até três atividades atinge $80,0 \%$, enquanto o de médicos é de $73,4 \%$ (Tabela 5.3). Quanto ao total de profissionais com mais de três atividades, obsenva-se pequena superioridade do contingente masculino (26,6\% para os homens e $19,9 \%$ para as mulheres). Mais uma vez, os dados da pesquisa confirmam essa realidade, quando indicam, por 
exemplo, que a atividade de plantão é exercida pelas médicas em igual proporção (50\% para os homens e $46,6 \%$ para as mulheres).

Tabela 5.3 - Médicos distribuídos por gênero segundo número de atividades. Brasil - 1995

\begin{tabular}{lllll}
\hline \multirow{2}{*}{$\begin{array}{c}\text { Número de } \\
\text { atividades }\end{array}$} & \multicolumn{2}{c}{ Masculino } & \multicolumn{2}{c}{ Feminino } \\
\cline { 2 - 5 } & v. abs. & $(\%)$ & v. abs. & $(\%)$ \\
\hline Uma & 20.624 & 17,2 & 10.491 & 17,8 \\
Duas & 30.839 & 25,8 & 18.916 & 32,2 \\
Três & 36.395 & 30,4 & 17.625 & 30,0 \\
Quatro & 20.362 & 17,0 & 8.039 & 13,6 \\
Mais de quatro & 11.453 & 9,6 & 3.709 & 6,3 \\
\hline TOTAL* & 119.673 & 100,0 & 58.780 & 100,0 \\
\hline
\end{tabular}

- A diferença observada em relação ao total geral de médicos refere-se aos aposentados, afastados e desempregados e àqueles que năo declararam.

Fonte: Pesquisa "Perfil dos Médicos no Brasil", Fiocruz/CFM.

Sem a intenção de transformar as mulheres em mártires do mundo do trabatho, cuja hegemonia cultural ainda é masculina, os depoimentos registrados nos autorizam a afirmar que elas sofrem preconceitos, obstáculos familiares e sociais para exercer a profissão. Na opinião de Saffioti (1976:47),

a perspectiva do casamento e a necessidade que muitas vezes se impöe de interromper o trabalho e a situação de volta ao emprego depois de um longo periodo de inatividade profissional são fatores que pesam no encaminhamento das mulheres para ocupaçōes subalternas e que envolvem menores responsabilidades.

A realidade mostra que aliar casamento, filhos, marido e trabalho tem sido uma enorme luta que as mulheres têm que travar diariamente para conciliar a vida privada e a profissional:

Dupla jornada de trabalho. Falta de credibilidade (ainda) da mulher como profissional capacitada. (ginecologista, feminino, 41 anos, Mato Grosso)

Dificuldade e desgaste em conciliar o trabalho e família. Preconceito da propria classe e equipe profissional em geral. (médico do trabalho, feminino, 40 anos, BA)

Preconceitos para obter emprego (preterida em relação ao homem com base na idéia que, como mulher, tinha quem me sustentasse e/ou não precisava sustentar famílial). (psiquiatra, feminino, 45 anos, MC) 
Falta de estímulo do companheiro para o crescimento profissional da esposa (machismo). Não-cooperação nas atividades domésticas e familiares. (médico do trabalho, feminino, 51 anos, SE)

Dificuldade para conciliar filhos e trabalho. Dificuldades para trabalhar em hospitais, onde fui barrada por ser mulher. (pediatra, feminino, 31 anos, PR)

Os maridos não compreendem. Os colegas não reconhecem como iguais. (clínico geral, feminino, 31 anos, SE)

Embora esse contingente feminino trabalhe tanto quanto o masculino e esteja submetido à mesma estrutura de prestação de serviços, ele aufere rendimentos inferiores. O mercado de trabalho médico caracteriza-se por uma significativa desigualdade distributiva da renda entre os sexos, verificando-se maior concentração das mulheres nas faixas de renda mais baixas. Enquanto $66,2 \%$ delas ganham até dois mil dólares, apenas 34,0\% dos homens se encontram nesta situação (Gráfico 5.1 e Tabela 5.4). Ocorre o oposto nas faixas de renda mais elevadas: $20,7 \%$ dos homens percebem renda entre 4.001 e oito mil dólares, ao passo que somente $5,2 \%$ das mulheres têm esse rendimento. Na faixa acima de oito mil dólares, o contingente feminino representa apenas $0,5 \%$, enquanto o masculino atinge $4,0 \%$.

As disparidades são visiveis e contundentes, mostrando um efetivo desnível entre o que as médicas afirmam trabalhar e o que recebem. Para avaliar corretamente o que ocorre, seria necessário investigar mais qualitativamente as causas dessas visíveis diferenças e das singularidades que envolvem esse mundo feminino.

\section{Gráfico 5.1 - Médicos distribuídos por gênero segundo faixas de renda.* Brasil - 1995}

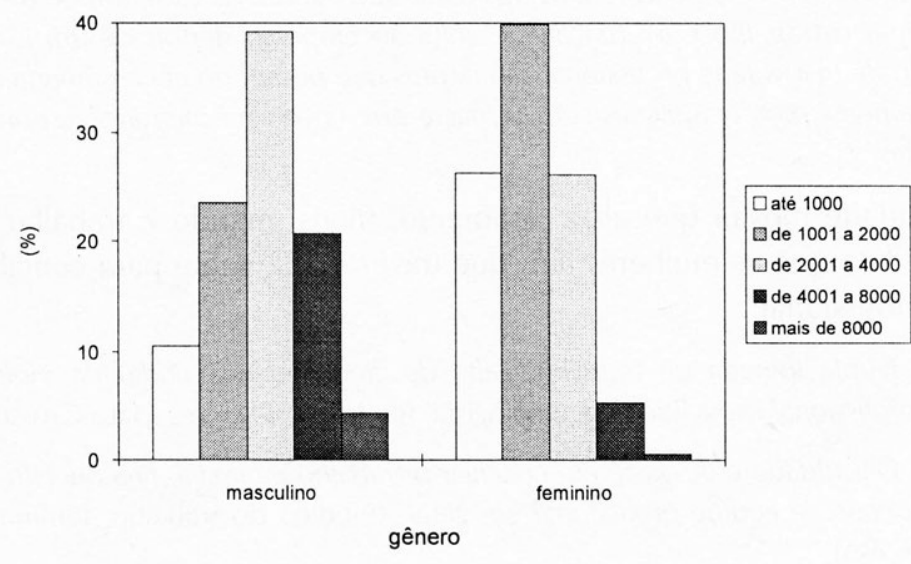

* Em dólares.

Fonte: Pesquisa "Perfil dos Médicos no Brasil", Fiocruz/CFM. 
Tabela 5.4 - Médicos distribuídos por gerações e gênero segundo faixas de renda. Brasil - 1995

\begin{tabular}{lrrrrrrrrrrrrr}
\hline $\begin{array}{c}\text { Faixas de renda } \\
\text { (em dolares) }\end{array}$ & \multicolumn{2}{c}{ Anos 90} & \multicolumn{2}{c}{ Anos 80} & \multicolumn{2}{c}{ Anos 70} & \multicolumn{3}{c}{ Anos 60} & \multicolumn{2}{c}{ Anos 50} & \multicolumn{3}{c}{ Anos 40 } \\
\cline { 2 - 14 } & Masc. & Fem. & Masc. & Fem. & Masc. & Fem. & Masc. & Fem. & Masc. & Fem. & Masc. & Fem. \\
\hline Até 1.000 & 39,6 & 47,3 & 9,6 & 26,1 & 4,4 & 17,3 & 7,3 & 15,7 & 11,8 & 24,0 & 17,5 & 41,5 \\
1.001 a 2.000 & 35,8 & 39,2 & 28,2 & 41,7 & 20,6 & 40,9 & 19,4 & 39,0 & 22,0 & 37,2 & 15,1 & 0,0 \\
2.001 a 4.000 & 20,0 & 13,3 & 39,1 & 27,3 & 43,3 & 30,8 & 43,7 & 39,6 & 43,0 & 36,7 & 43,5 & 22,6 \\
4.001 a 8.000 & 4,4 & 0,3 & 19,5 & 4,4 & 26,1 & 10,3 & 23,5 & 5,2 & 20,9 & 1,4 & 19,1 & 35,8 \\
8.001 e mais & 0,3 & 0,0 & 3,7 & 0,5 & 5,7 & 0,7 & 6,1 & 0,4 & 2,2 & 0,6 & 4,9 & 0,0 \\
\hline TOTAL & 100,0 & 100,0 & 100,0 & 100,0 & 100,0 & 100,0 & 100,0 & 100,0 & 100,0 & 100,0 & 100,0 & 100,0 \\
\hline
\end{tabular}

* As décadas consideradas seguem a tipologia criada no Quadro 1.2 (Cap. 1), que associa a geraçăo dos médicos formados com a respectiva faixa etária.

Fonte: Pesquisa "Perfil dos Médicos no Brasil", Fiocruz/CFM.

\section{ESCOLHA PROFISSIONAL: FONTE DE DISCRIMINAÇĀO?}

O mercado de serviços médicos é amplo e profundamente especializado, porém os dados aqui apresentados mostram que as mulheres não acompanham essa diversificação, ao contrário, elas se concentram em poucas áreas. É marcante o fato de que, dentre 64 especialidades, apenas cinco concentram mais de $60 \%$ de todo o contingente feminino. São médicas pediatras, ginecologistas, clínicas gerais, cardiologistas e dermatologistas (Tabela 5.5).

Por outro lado, raras são as especialidades em que essas profissionais constituem maioria. Mesmo assim, é preciso questionar o impacto e a importância de boa parte dessas especialidades na prestação de serviços médicos. Excetuando a pediatria, estamos nos referindo às áreas de dermatologia, sexologia, genética clínica, cirurgia da mão, tisiologia, nutrologia e medicina sanitária, nas quais há predominância das mulheres. É fundamental observar que, em apenas 13 das 64 especialidades, ocorre essa predominância feminina, que, ainda assim, é questionável pelo fato de serem áreas - excetuando a pediatria e a dermatologia - sem impacto no mercado de serviços médicos. Por exemplo, as cinco especialidades em que há predominância das mulheres (com índice superior a 60\%) - sexologia, genética clínica, hemoterapia, cirurgia da mão e tisiologia - não somam nem $1 \%$ de profissionais em todo o País. Ou seja, dos 183.052 médicos, apenas 1.367 (homens e mulheres) estão nestas cinco áreas de especialização (Tabela 5.6).

Estudos realizados no Brasil sobre a condição da mulher no mercado de trabalho em saúde - Leite \& Machado (1981), Médici (1989), Machado (1989, 1993) mostram que a escolha da mulher quanto à área de atuação, de modo geral, recai em áreas semelhantes às que elas tradicionalmente desenvolvem na esfera privada. No caso da medicina, também ocorre essa preferência 'sexual' pelas áreas da pedia- 
tria, dermatologia, clínica geral e nutrologia, havendo, assim, uma certa conjugação entre as funções 'domésticas' e as 'profissionais'. Poucas são as médicas que se dedicam a trabalhar, por exemplo, em áreas cirúrgicas, excetuando-se de cirurgia de mão. Neste caso, além de haver um contingente mínimo de médicos dedicados a ela, esta especialidade exige 'habilidades finas', provavelmente mais afetas às muIheres.

A condiçāo feminina, segundo $21,6 \%$ das médicas brasileiras, influenciou a escolha da especialidade a ser exercida. As respostas abertas (correspondentes ao material qualitativo da pesquisa) ressaitam questões ligadas à discriminação e ao preconceito sociais. Assim, as médicas escolhem especialidades que asseguram boa aceitação da clientela e reconhecimento profissional junto aos colegas:

Para especialidades da área cirúrgica são mais bem aceitos os homens, com exceção da gineco-obstetrícia. (ginecologista, feminino, 26 anos, SP)

Não fui aceita em residências de neurocinurgia, apesar de ter alcançado notas melhores. (intensivista, feminino, 33 anos, SP)

Em medicina do trabalho, por exemplo, a médica não é aceita e sempre recebe menor remuneração. (clínico geral, feminino, 35 anos, PE)

Há obstáculos por parte dos colegas médicos. Obstáculos por parte dos familiares dos pacientes, na área cirúrgica. (ginecologista, feminino, 27 anos, PI)

Fui aprovada para residência em cirurgia no interior de São Paulo com 9,5 pontos e não pude fazer residência, o que até hoje tem me prejudicado. (ginecologista, feminino, 50 anos, MS)

A hostilidade, mesmo que não seja aberta, é sentida pelas médicas de modo tăo intenso, que elas acabam desistindo de provar sua 'capacidade' para atuar de igual para igual em relação aos colegas homens:

Não vale a pena passar a vida inteira provando aos colegas e pacientes que ser mulher não atrapalha ou impede um bom desempenho profissional. (pediatra, feminino, 27 anos, RN)

Iniciei o internato em cirurgia, mas o ambiente machista e a grande responsabilidade me desestimularam, pois era mais exigida e menos prezada ou depreciada na conduta. (pediatra, feminino, 38 anos, $\mathrm{RJ}$ )

Da mesma forma, a escolha profissional recai sobre áreas e funçōes semeIhantes à 'condição feminina' da vida privada: materno-infantil, aconselhamento, cosmetologia e ensino-burocracia, entre outras. As justificativas oferecidas são elucidativas:

$O$ instinto maternal, o carinho e o desejo de ter filhos me aproximaram da pediatria, e a afinidade foi imediata. (pediatra, feminino, 39 anos, AC)

Aspectos da minha personalidade como mulher colaboraram na escolha da psiquiatria, e atendo crianças e adolescentes. (psiquiatra, feminino, 46 anos, SP) 
$O$ lado materno sempre é relevante para a mulher-pediatra. (pediatra, feminino, 34 anos, DF)

Como mulher, posso compreender melhor os problemas que afligem as mulheres no campo da ginecologia e obstetricia. (ginecologista, feminino, 35 anos, PE)

Meu próprio perfil psicologico de mulher, minha sensibilidade mais desenvolvida. $O$ conhecimento de algumas situaçōes específicas da mulher me fez decidir por determinada especialidade. (ginecologista, feminino, 43 anos, BA)

Horários flexíveis compatíveis com os dois mundos - privado e público - e horários 'comerciais' - mais definidos, sem imprevisibilidades, não exigindo sair à noite para atender urgências - constituem outro conjunto de fatores que interferem na escolha da especialidade. Entre as entrevistadas que sentem obstáculos ao exercício profissional, 19,9\% apontam que escolheram especialidades cujo horário, mais maleável, permite dedicação à familia, e 19,6\% gostariam de ter jornadas mais definidas, sem necessidade de saídas noturnas para atendimentos de urgência. Tal preferência, acreditamos, nāo está ligada a uma escolha espontânea por menos 'trabaIho' e mais 'lazer', com conseqüente melhoria da qualidade de vida, mas, sim, ao fato de ter que enfrentar a dupla jornada no lar, aliado às discriminaçōes sociais e ao pouquíssimo retorno financeiro e social:

Escolhi uma especialidade em que pudesse conciliar melhor minhas atividades de médica, mãe e dona-de-casa. (dermatologista, feminino, 37 anos, ES)

Procurei uma especialidade em que fosse possivel conciliar a função de esposa e mãe. (intensivista, feminino, 44 anos, ES)

É penoso conciliar afazeres e responsabilidades domésticas com a vida profissional, não podendo nunca dispor de 24 horas por dia para a medicina. (pediatra, feminino, 37 anos, MG)

É difícil para uma mulher sair à noite, dar plantões fora e não poder planejar seus horários. Para conciliar casa, marido, filhos e trabalho, não pode haver imprevistos nem urgéncias. (neurologista pediátrico, feminino, 39 anos, MG)

Optei por algo menos estressante, com mais tempo disponivel para atividades domésticas. (cirurgiāo geral, feminino, 39 anos, PB)

Não se pode incorrer no erro de associar linearmente a área de atuação a uma escolha marcada apenas pelo desejo e por vontades pessoais, ou, pior ainda, à condição feminina. Ao contrário, a escolha é racional e pontilhada de impedimentos culturais e sociais, que conduzem a áreas nas quais os conflitos, os ajustes culturais são mais brandos. 
Tabela 5.5 - Médicos distribuídos por gênero segundo especialidade principal. Brasil - 1995

\begin{tabular}{|c|c|c|c|c|c|}
\hline \multirow{2}{*}{ Especialidade principal } & \multicolumn{2}{|c|}{ Feminino } & \multicolumn{2}{|c|}{ Masculino } & \multirow{2}{*}{ TOTAL } \\
\hline & v. abs. & $(\%)$ & v. abs. & $(\%)$ & \\
\hline Administração hospitalar & 590 & 1,0 & 967 & 0,8 & 1.557 \\
\hline Alergia e Imunoterapia & 300 & 0,5 & 198 & 0,2 & 498 \\
\hline Anestesiologia & 1.833 & 3,1 & 7.740 & 6,3 & 9.573 \\
\hline Angiologia & 111 & 0,2 & 361 & 0,3 & 472 \\
\hline Broncoesofagologia & 194 & 0,3 & 294 & 0,2 & 488 \\
\hline Cirururgia de cabeça e pescoço & 51 & 0,1 & 689 & 0,6 & 740 \\
\hline Cirurgia cardiovascular & 247 & 0,4 & 1.278 & 1,0 & 1.525 \\
\hline Cirurgia geral & 519 & 0,9 & 9.530 & 7,7 & 10.049 \\
\hline Cirurgia pediátrica & 797 & 1,3 & 1.622 & 1,3 & 2.419 \\
\hline Cirurgia plástica & 509 & 0,8 & 2.886 & 2,3 & 3.395 \\
\hline Cirurgia torácica & 223 & 0,4 & 555 & 0,5 & 778 \\
\hline Cirurgia vascular & 689 & 1,2 & 1.597 & 1,3 & 2.286 \\
\hline Cancerologia & 644 & 1,1 & 915 & 0,7 & 1.559 \\
\hline Cardiologia & 2.245 & 3,7 & 6.614 & 5,4 & 8.859 \\
\hline Cirurgia da māo & 422 & 0,7 & 197 & 0,2 & 619 \\
\hline Citopatologia & 357 & 0,6 & 302 & 0,2 & 659 \\
\hline Dermatologia & 2.132 & 3,6 & 1.358 & 1,1 & 3.490 \\
\hline Eletroencefalografia & 360 & 0,6 & 664 & 0,5 & 1.024 \\
\hline Endocrinologia e Metabolia & 957 & 1,6 & 1.097 & 0,9 & 2.0 .54 \\
\hline Endoscopia digestiva & 114 & 0,2 & 602 & 0,5 & 710 \\
\hline Fisiatria & 194 & 0,3 & 305 & 0,2 & 499 \\
\hline Foniatria* & - & - & - & - & . \\
\hline Gastroenterologia & 898 & 1,5 & 1.379 & 1,1 & 2.277 \\
\hline Genética clínica & 113 & 0,2 & 11 & 0,0 & 124 \\
\hline Geriatria e Cerontologia & 148 & 0,2 & 230 & 0,2 & 378 \\
\hline Gineco-Obstetrícia & 8.521 & 14,2 & 13.054 & 10,6 & 21.575 \\
\hline Hansenologia & 18 & 0,0 & 115 & 0,1 & 133 \\
\hline Hematologia & 449 & 0,7 & 592 & 0,5 & 1.041 \\
\hline Hemoterapia & 311 & 0,5 & 127 & 0,1 & 438 \\
\hline Homeopatia & 727 & 1,2 & 1.701 & 1,4 & 2.428 \\
\hline Infectologia & 431 & 0,7 & 818 & 0,7 & 1.249 \\
\hline Mastologia & 47 & 0,1 & 166 & 0,1 & 213 \\
\hline Medicina do trabalho & 856 & 1,4 & 3.471 & 2,8 & 4.327 \\
\hline Medicina esportiva & 73 & 0,1 & 146 & 0,1 & 219 \\
\hline
\end{tabular}


Tabela 5.5 - Médicos distribuídos por gênero segundo especialidade principal. Brasil - 1995 (continuação)

\begin{tabular}{|c|c|c|c|c|c|}
\hline \multirow[t]{2}{*}{ Especialidade principal } & \multicolumn{2}{|c|}{ Feminino } & \multicolumn{2}{|c|}{ Masculino } & \multirow{2}{*}{ TOTAL } \\
\hline & v. abs. & $(\%)$ & v. abs. & $(\%)$ & \\
\hline Medicina geral comunitária & 998 & 1,7 & 3.814 & 3,1 & 4.812 \\
\hline Medicina interna & 4.200 & 7,0 & 10.466 & 8,5 & 14.666 \\
\hline Medicina legal & 79 & 0,1 & 299 & 0,2 & 378 \\
\hline Medicina nuclear & 24 & 0,0 & 59 & 0,0 & 83 \\
\hline Medicina sanitária & 1.088 & 1,8 & 926 & 0,8 & 2.014 \\
\hline Medicina do tráfego & 0 & 0,0 & 264 & 0,2 & 264 \\
\hline Nefrologia & 565 & 0,9 & 1.134 & 0,9 & 1.699 \\
\hline Neurocirurgia & 203 & 0,3 & 1.284 & 1,0 & 1.487 \\
\hline Neurofisiologia clínica & 39 & 0,1 & 105 & 0,1 & 144 \\
\hline Neurologia & 618 & 1,0 & 1.275 & 1,0 & 1893 \\
\hline Neurologia pediátrica & 406 & 0,7 & 391 & 0,3 & 797 \\
\hline Nutrologia & 68 & 0,1 & 52 & 0,0 & 120 \\
\hline Oftalmologia & 1.628 & 2,7 & 4.872 & 4,0 & 6.500 \\
\hline Ortopedia e Traumatologia & 179 & 0,3 & 6.635 & 5,4 & 6.814 \\
\hline Otorrinolaringologia & 537 & 0,9 & 2.388 & 1,9 & 2.925 \\
\hline Patologia & 512 & 0,9 & 880 & 0,7 & 1.392 \\
\hline Patologia clínica & 212 & 0,4 & 786 & 0,6 & 998 \\
\hline Pediatria & 14.688 & 24,5 & 9.962 & 8,1 & 24.650 \\
\hline Pneumologia & 754 & 1,3 & 870 & 0,7 & 1.624 \\
\hline Proctologia & 197 & 0,3 & 399 & 0,3 & 596 \\
\hline Psiquiatria & 1.992 & 3,3 & 4.132 & 3,4 & 6.124 \\
\hline Radiologia & 1.392 & 2,3 & 2.282 & 1,9 & 3.674 \\
\hline Radioterapia & 43 & 0,1 & 309 & 0,3 & 352 \\
\hline Reumatologia & 654 & 1,1 & 458 & 0,4 & 1.112 \\
\hline Sexologia & 7 & 0,0 & 0 & 0,0 & 7 \\
\hline Terapia intensiva & 770 & 1,3 & 900 & 0,7 & 1.670 \\
\hline Tisiologia & 118 & 0,2 & 61 & 0,0 & 179 \\
\hline Urologia & 66 & 0,1 & 2.340 & 1,9 & 2.406 \\
\hline Outras & 333 & 0,6 & 408 & 0,3 & 741 \\
\hline Ignorada & 1.449 & 2,4 & 3.821 & 3,1 & 5.270 \\
\hline TOTAL & 59.899 & 100,0 & 123.153 & 100,0 & 183.052 \\
\hline
\end{tabular}

* Na amostra não houve seleção de foniatras.

Fonte: Pesquisa "Perfil dos Médicos no Brasil", Fiocruz/CFM. 
Tabela 5.6 - Médicos distribuídos por gênero segundo especialidade principal. Brasil - 1995

\begin{tabular}{|c|c|c|c|c|c|c|}
\hline \multirow{2}{*}{ Especialidade principal } & \multicolumn{2}{|c|}{ Feminino } & \multicolumn{2}{|c|}{ Masculino } & \multicolumn{2}{|c|}{ TOTAL } \\
\hline & v. abs. & (\%) & v. abs. & $(\%)$ & v. abs. & (\%) \\
\hline Administraçāo hospitalar & 590 & 37,9 & 967 & 62,1 & 1.557 & 100,0 \\
\hline Alergia e Imunoterapia & 300 & 60,2 & 198 & 39,8 & 498 & 100,0 \\
\hline Anestesiologia & 1.833 & 19,1 & 7.740 & 80,9 & 9.573 & 100,0 \\
\hline Angiologia & 111 & 23,5 & 361 & 76,5 & 472 & 100,0 \\
\hline Broncoesofagologia & 194 & 39,8 & 294 & 60,2 & 488 & 100,0 \\
\hline Cirurgia de cabeça e pescoço & 51 & 6,9 & 689 & 93,1 & 740 & 100,0 \\
\hline Cirurgia cardiovascular & 247 & 16,2 & 1.278 & 83,8 & 1.525 & 100,0 \\
\hline Cirurgia geral & 519 & 5,2 & 9.530 & 94,8 & 10.049 & 100,0 \\
\hline Cirurgia pediátrica & 797 & 32,9 & 1.622 & 67,1 & 2.419 & 100,0 \\
\hline Cirurgia plástica & 509 & 15,0 & 2.886 & 85,0 & 3.395 & 100,0 \\
\hline Cirurgia torácica & 223 & 28,7 & 555 & 71,3 & 778 & 100,0 \\
\hline Cirurgia vascular & 689 & 30,1 & 1.597 & 69,9 & 2.286 & 100,0 \\
\hline Cancerologia & 644 & 41,3 & 915 & 58,7 & 1.559 & 100,0 \\
\hline Cardiologia & 2.245 & 25,3 & 6.614 & 74,7 & 8.859 & 100,0 \\
\hline Cirurgia da mão & 422 & 68,2 & 197 & 31,8 & 619 & 100,0 \\
\hline Citopatologia & 357 & 54,2 & 302 & 45,8 & 659 & 100,0 \\
\hline Dermatologia & 2.132 & 61,1 & 1.358 & 38,9 & 3.490 & 100,0 \\
\hline Eletroencefalografia & 360 & 35,2 & 664 & 64,8 & 1.024 & 100,0 \\
\hline Endocrinologia e Metabolia & 957 & 46,6 & 1.097 & 53,4 & 2.054 & 100,0 \\
\hline Endoscopia digestiva & 114 & 15,9 & 602 & 84,1 & 716 & 100,0 \\
\hline Fisiatria & 194 & 38,9 & 305 & 61,1 & 499 & 100,0 \\
\hline Foniatria* & - & - & - & - & - & - \\
\hline Gastroenterologia & 898 & 39,4 & 1.379 & 60,6 & 2.277 & 100,0 \\
\hline Genética clínica & 113 & 91,1 & 11 & 8,9 & 124 & 100,0 \\
\hline Geriatria e Gerontologia & 148 & 39,2 & 230 & 60,8 & 378 & 100,0 \\
\hline Gineco-Obstetrícia & 8.521 & 39,5 & 13.054 & 60,5 & 21.575 & 100,0 \\
\hline Hansenologia & 18 & 13,5 & 115 & 86,5 & 133 & 100,0 \\
\hline Hematologia & 449 & 43,1 & 592 & 56,9 & 1.041 & 100,0 \\
\hline Hemoterapia & 311 & 71,0 & 127 & 29,0 & 438 & 100,0 \\
\hline Homeopatia & 727 & 29,9 & 1.701 & 70,1 & 2.428 & 100,0 \\
\hline Infectologia & 431 & 34,5 & 818 & 65,5 & 1.249 & 100,0 \\
\hline Mastologia & 47 & 22,1 & 166 & 77,9 & 213 & 100,0 \\
\hline Medicina do trabalho & 856 & 19,8 & 3.471 & 80,2 & 4.327 & 100,0 \\
\hline Medicina esportiva & 73 & 33,3 & 146 & 66,7 & 219 & 100,0 \\
\hline
\end{tabular}


Tabela 5.6 - Médicos distribuídos por gênero segundo especialidade principal. Brasil - 1995 (continuação)

\begin{tabular}{|c|c|c|c|c|c|c|}
\hline \multirow[t]{2}{*}{ Especialidade principal } & \multicolumn{2}{|c|}{ Feminino } & \multicolumn{2}{|c|}{ Masculino } & \multicolumn{2}{|c|}{ TOTAL } \\
\hline & v. abs. & $(\%)$ & v. abs. & $(\%)$ & v. abs. & $(\%)$ \\
\hline Medicina geral comunitária & 998 & 20,7 & 3.814 & 79,3 & 4.812 & 100,0 \\
\hline Medicina interna & 4.200 & 28,6 & 10.466 & 71,4 & 14.666 & 100,0 \\
\hline Medicina legal & 79 & 20,9 & 299 & 79,1 & 378 & 100,0 \\
\hline Medicina nuclear & 24 & 28,9 & 59 & 71,1 & 83 & 100,0 \\
\hline Medicina sanitária & 1.088 & 54,0 & 926 & 46,0 & 2.014 & 100,0 \\
\hline Medicina do tráfego & 0 & 0,0 & 264 & 100,0 & 264 & 100,0 \\
\hline Nefrologia & 565 & 33,3 & 1.134 & 66,7 & 1.699 & 100,0 \\
\hline Neurocirurgia & 203 & 13,7 & 1.284 & 86,3 & 1.487 & 100,0 \\
\hline Neurofisiologia clínica & 39 & 27,1 & 105 & 72,9 & 144 & 100,0 \\
\hline Neurologia & 618 & 32,6 & 1.275 & 67,4 & 1893 & 100,0 \\
\hline Neurologia pediátrica & 406 & 50,9 & 391 & 49,1 & 797 & 100,0 \\
\hline Nutrologia & 68 & 56,7 & 52 & 43,3 & 120 & 100,0 \\
\hline Oftalmologia & 1.628 & 25,0 & 4.872 & 75,0 & 6.500 & 100,0 \\
\hline Ortopedia e Traumatologia & 179 & 2,6 & 6.635 & 97,4 & 6.814 & 100,0 \\
\hline Otorrinolaringologia & 537 & 18,4 & 2.388 & 81,6 & 2.925 & 100,0 \\
\hline Patologia & 512 & 36,8 & 880 & 63,2 & 1.392 & 100,0 \\
\hline Patologia clínica & 212 & 21,2 & 786 & 78,8 & 998 & 100,0 \\
\hline Pediatria & 14.688 & 59,6 & 9.962 & 40,4 & 24.650 & 100,0 \\
\hline Pneumologia & 754 & 46,4 & 870 & 53,6 & 1.624 & 100,0 \\
\hline Proctologia & 197 & 33,1 & 399 & 66,9 & 596 & 100,0 \\
\hline Psiquiatria & 1.992 & 32,5 & 4.132 & 67,5 & 6.124 & 100,0 \\
\hline Radiologia & 1.392 & 37,9 & 2.282 & 62,1 & 3.674 & 100,0 \\
\hline Radioterapia & 43 & 12,2 & 309 & 87,8 & 352 & 100,0 \\
\hline Reumatologia & 654 & 58,8 & 458 & 41,2 & 1.112 & 100,0 \\
\hline Sexologia & 7 & 100,0 & 0 & 0,0 & 7 & 100,0 \\
\hline Terapia intensiva & 770 & 46,1 & 900 & 53,9 & 1.670 & 100,0 \\
\hline Tisiologia & 118 & 65,9 & 61 & 34,1 & 179 & 100,0 \\
\hline Urologia & 66 & 2,7 & 2.340 & 97,3 & 2.406 & 100,0 \\
\hline Outras & 333 & 44,9 & 408 & 55,1 & 741 & 100,0 \\
\hline Ignorada & 1.449 & 27,5 & 3.821 & 72,5 & 5.270 & 100,0 \\
\hline TOTAL & 59.899 & 32,7 & 123.153 & 67,3 & 183.052 & 100,0 \\
\hline
\end{tabular}

* Na amostra não houve seleção de foniatras.

Fonte: Pesquisa "Perfil dos Médicos no Brasil", Fiocruz/CFM. 



\section{AS CONDIÇŌES DE TRABALHO MÉDICO}

\section{TRABALHO E DESGASTE PROFISSIONAL}

Discutindo as relações entre processo de produção e saúde, Laurell \& Noriega (1989:115) conferem papel de destaque ao conceito de desgaste em sua construção teórico-metodológica. Sua definição está associada à "perda da capacidade, efetiva e/ou potencial, biológica e psíquica" do indivíduo, considerando-o mediador privilegiado entre o processo de trabalho e a constituiçăo biopsíquica característica de grupos de trabalhadores. Essa formulação teórica propõe que, no processo de trabalho, esses grupos estão submetidos a cargas físicas, químicas, biológicas, fisiológicas e psíquicas que "interatuam dinamicamente entre si e com o corpo do trabaIhador, gerando processos de adaptação que se traduzem em desgaste". A conformação biológica e psíquica adquirida pelos homens historicamente é resultante da combinação entre desgaste e reprodução (reposição e desenvolvimento da capacidade biopsíquica), que, por sua vez, determina uma grande diversidade de doenças - o perfil patológico de um grupo social.

Esse conceito de desgaste é suficientemente abrangente e possibilita um entendimento da relação trabalho-saúde, de forma que o processo de trabalho ganha um papel central e a saúde deixa de ser considerada somente em sua antinomia. Além disso, a noçăo de processo biopsíquico e desgaste como interação das cargas com o corpo do trabalhador possibilita entender o humano como uma unidade em relação com o seu mundo.

No caso aqui analisado, as perguntas feitas aos médicos - Você considera sua atividade profissional desgastante? Por quê? - nos deram condições de identificar as questões e algumas características do trabalho que mais os atingem. É interessante notar que grande parte dessas respostas se refere aos aspectos psíquicos do desgaste.

Seligmann Silva (1987) desenvolve esses aspectos acima referidos, denominando-os de "desgaste mental", apoiada na conceituação de Laurell \& Noriega. 
Com uma particular preocupação com a identificação das fontes 'laborais' de tensão, ela realiza diversos estudos de caso em diferentes ocupaçōes. Chama a atenção para o fato de que as fontes de tensão agem, em geral, de forma integrada, resultantes das condições e da organização do trabalho (Seligmann Silva, 1987:244-245).

Sua opção teórica para definir desgaste é explicada por sua abrangência e pelo caráter integrador do conhecimento que tem sido produzido nesse campo. A ele, acrescenta-se a idéia de que "no trabalho alienado há uma utilização deformada e deformante das potencialidades psíquicas, assim como do próprio corpo" (Seligmann Silva, 1994:79). Deformação, enfatiza a autora, traz a idéia de transformação negativa, perda de um estado anterior mais satisfatório, mais valorizado. Como a idéia de desgaste está fortemente associada a máquinas e a elementos físicos, Seligmann Silva justifica seu uso em relação aos aspectos mentais fundamentada em Jervis (1979) e Doray (1981), afirmando que as pessoas e as relaçóes interpessoais são reificadas no interior do processo de produção capitalista, de onde emerge a alienação, quando parte da subjetividade do trabalhador é expropriada.

Com o conceito de desgaste, Seligmann Silva construiu um tripé teórico integrador dos conhecimentos, acrescentando os conceitos de identidade em processo a identidade está em permanente transformação, mediada pelas experiências laborais - e de economia psicossomática - que designa a densa integração existente entre os processos mentais e orgânicos, segundo Dejours (1994) e Marty (1980). A articulação entre eles, na opinião de Seligmann Silva (1994:84-85), se dá, em primeiro lugar, porque

existe um desgaste da identidade que atinge a personalidade e a vida mental $\mathrm{e}$, por conseguinte, a economia psicossomática (...); em segundo lugar, vemos que a estabilidade dessa economia - essencial para a preservação da saúde - pode ser rompida pela experiência social (experiência de trabalho).

Utilizando outro construto teórico, Palácios (1993) realizou um estudo dos trabalhadores da saúde de um hospital geral, buscando analisar as relaçōes entre o modo como o trabalho se organiza num hospital geral e o sofrimento psíquico dos que lá atuam. ${ }^{1}$ A proposta teórico-metodológica desenvolvida pela autora é de um modelo (Blauner, 1973) de entendimento do sofrimento psíquico dos trabalhadores em que este se articula com a organização do trabalho, tendo como categorias mediadoras os sentimentos de impotência, falta de sentido da tarefa, isolamento social e auto-estranhamento ou distanciamento de si. Os determinantes da organização do trabalho - como pessoas e meios se articulam em função de um resultado almejado - utilizados foram: qualificação dos trabalhadores, participação, condiçōes de trabatho e divisão do trabalho.

1 O sofrimento psíquico tem sido estudado através do SRQ-20 (Self Report Questionnaire). Este instrumento, validado nacional e internacionalmente, detecta distúrbios mentais leves. Para maiores informações, ver HARDING (1976), MARI (1986) e SILVA FILHO et al. (1992). 
Com esta compreensão, Palácios demonstra que determinada estrutura da organização do trabalho em dada situação concreta pode levar certo segmento de trabalhadores a experimentar sentimentos negativos, como de impotência, falta de sentido, isolamento social e auto-estranhamento. Estes, por sua vez, também não podem ser considerados fatores isolados ou isoláveis, já que estão articulados entre si. Sendo assim, o sofrimento psíquico deve ser entendido a partir da idéia de sofrimento como "sentimento de vida contrariada" (Canguilhem, 1966), associada à de especificidade do psíquico - situa-se no espaço entre a saúde e a doença mental, caracterizado por uma intensa luta contra a doença e o próprio sofrimento (Dejours, 1987, 1993).

As categorias que Palácios (1993) utiliza para compreender a mediação entre trabalho e sofrimento psíquico podem ser apresentadas resumidamente como:

a) Carência de poder - está relacionada à perda do controle do trabalhador sobre os instrumentos de trabalho, sobre o ritmo, os movimentos e as habilidades. Isto significa que o trabalhador detém o controle sobre seu processo imediato de trabalho quando pode controlar o ritmo, está livre de pressóes, livre para movimentar-se, pode controlar a quantidade e a qualidade da produção e escolher a técnica de trabalho.

b) Falta de significação do trabalho - é atribuída à divisão do trabalho. Esse fato leva à ausência de responsabilidade concreta do trabalhador em relação a seu trabaIho, não requerendo a sua compreensão do processo como um todo. A responsabilidade, a solução de problemas, a tomada de decisões, por exemplo, são atribuiçōes de terceiros, alheios inclusive à dinâmica do processo de trabalho em si. Esta relaçāo fragmentada rouba o senso de propósito do indivíduo.

c) Isolamento social - refere-se ao sentimento de nāo pertencer à comunidade de trabatho. Ser membro deste tipo de grupo implica a adesão aos objetivos institucionais e resulta em sentimentos de lealdade com a organização, o que significa dizer que uma comunidade laboral é composta por uma rede de relações sociais que se estabelecem no trabalho e que é valorizada pelos seus membros.

d) Auto-estranhamento - ausência de envolvimento do sujeito com o trabaIho. Tem relação próxima, embora não causal, com os outros componentes. Isto significa dizer que, quanto maior o controle do trabalhador sobre o processo de trabalho imediato, quanto maiores a significação do trabaIho e a integração do trabalhador, maior será a chance de que o trabalho seja a expressão pessoal desse trabalhador e não o conduza ao 'estranhamento'.

Enfim, ao considerar as características da organização e do processo de trabaIho em diferentes setores do hospital (emergência, ambulatório, internação etc.) e os 
indices observados de sofrimento entre os médicos, a autora pôde demonstrar a importância dessa mediação. ${ }^{2}$ Assinala Palácios (1993:91):

não existe apenas um fator responsável pelo sofrimento dos trabalhadores, mas uma rede de processos que se interpenetram, gerando situaçōes de sofrimento.

Em setores hospitalares como o de emergência, o inesperado, o imprevisível, o incontrolável são uma característica do atendimento. Estudos realizados em hospitais de emergências mostram que

quanto às condiçōes ambientais em que o trabalho de atendimento em emergência se realiza, faltam os instrumentos adequados à disposição dos trabalhadores. Tais elementos, necessários ao desempenho das funçöes, podem não estar disponiveis, por um lado, pela falta de recursos para a compra do material de consumo imediato - por exemplo, remédios, peças de reposição dos aparethos. Por outro lado, mesmo aquelas unidades bem aparelhadas podem sofrer com a sobrecarga de demanda decorrente de suas até então melhores condiçōes - tanto por aumento da procura, quanto pelo agravamento dos quadros clínicos, longa peregrinação pelos hospitais. (Rego \& Palácios, 1996:98)

Estes autores procuram definir o processo de trabalho num hospital de emergência como sendo a possibilidade diária e ininterrupta de ter como objeto de trabalho uma

pessoa gravemente doente que precisa de cuidados imediatos, que corre risco de vida. A finalidade do processo é salvar a vida do paciente, aliviar seu sofrimento intenso, oferecendo os primeiros cuidados. (Rego \& Palácios, 1996:97)

Dessa forma, não seriam somente a morte ou o sofrimento do indivíduo que explicariam o sofrimento do médico, mas esse sentimento de impotência, de perda de controle sobre seu trabalho, de impossibilidade de fazer algo positivo para o paciente.

Tais sentimentos, em nossa opinião, também podem estar presentes quando a instituição na qual o médico desempenha as tarefas possui uma estrutura fortemente burocrática, com a adoção de procedimentos técnicos e administrativos que cerceiam sua autonomia. Com esta hipótese, passaríamos a considerar todos os processos que limitam a autonomia profissional também como mediadores da relação sofrimento psíquico-trabalho.

Para o estudo que aqui apresentamos, a análise de Palácios (1993) sobre o sentimento de perda da significação do conteúdo da tarefa desempenhada é esclarecedora para estabelecer a correta relação entre autonomia técnica e os efeitos danosos do ambiente na vida diária do médico, especialmente se este trabalha em or-

2 Como exemplo, consideremos sua observação de que a diferença entre as freqüências de sofrimento dos médicos na emergência e no conjunto dos outros setores se manteve, considerando-se todos os estratos das variáveis sócio-demográficas. 
ganizaçōes hospitalares. Quando, por exemplo, o médico atende um paciente em estado de saúde grave, sem muitas chances de que o desfecho seja positivo, este sentimento torna-se agudo e visível. Esta percepção é ainda mais forte para algumas áreas e setores de atuação médica. Por sua natureza, estrutura e funcionamento, um hospital apresenta um ambiente favorável ao estresse, uma vez que as ambigüidades, as incertezas humanas, são pouco toleradas, porque lá o que está em questão, com freqüência, é a vida de um paciente. Rego \& Palácios (1996:97-98) mostram que:

Outro aspecto importante das condiçōes ambientais é que na emergência do hospital estudado o ambiente é mal iluminado, vive superlotado, pacientes são atendidos até na maca da ambulância, onde chegam por falta de lugar, e os leitos săo amontoados (...). Outra característica marcante desse setor é que ele é procurado por pacientes com quadros graves de dor intensa, que querem alivio imediato. (...) Isso confere ao trabalho neste ambiente uma pressão permanente e imprime um ritmo intenso (...), o que aumenta a mortalidade de casos potencialmente evitáveis. (..) As principais conseqüências para os médicos são o sentimento de impotência originado da falta de controle sobre o processo imediato de trabalho, o sentimento de perda das tarefas e o isolamento.

Esta formulação teórica encontra paralelo nas duas principais correntes que estudam as relaçōes entre saúde mental e trabalho: a psicodinâmica do trabalho e a fundamentada no conceito de estresse. ${ }^{3}$ Nesta última a noção de grau de controle do trabalho pelo indivíduo está correlata à noção de impotência, de falta de sentido, de suporte social, bem como à de isolamento social. Já na formulação da psicodinâmica, a dinâmica do reconhecimento descrita por Dejours (1993) passa pela possibilidade de intervenção do indivíduo sobre o processo imediato de trabalho; a dinâmica da cooperação leva em conta a abordagem sobre o isolamento social, sendo a busca de sentido uma das questōes-chave da intervenção da psicodinâmica.

Embora nossa investigação não tenha abrangido o estudo do sofrimento psíquico dos médicos em si, a análise das respostas oferecidas no quesito "por que consideram sua atividade desgastante" permite fazer algumas afirmaçōes. Ainda que tais abordagens não sigam metodologias próprias da epidemiologia, existem correlações positivas entre os diversos aspectos referidos como mediadores da relação sofrimento psíquico-trabalho e a avaliação sobre desgaste decorrente do trabalho (Pitta, 1990; Silva Filho et al., 1992; Palácios, 1993; e Jardim, 1994, entre outros). Seria interessante que estudos específicos, de natureza epidemiológica, aprofundassem algumas questōes que discutiremos aqui.

Utilizando a construção social feita pelos próprios médicos sobre 'desgaste', encontramos respaldo na literatura disponivel, em seus aspectos tanto físicos quanto psíquicos. A seguir, iremos identificar e caracterizar o problema, levando em consideração diversas variáveis sócio-econômicas obtidas na pesquisa.

3 Para maiores críticas sobre essas correntes, ver: SchabracQ, Winnubst \& COOPER (1996) e Dejours $(1987,1993,1994)$. 


\section{ATIVIDADE MÉDICA: UMA PRÁTCA DESGASTANTE}

Lidar com vidas quase sempre em situações de fragilidade, tomar decisões que envolvem riscos vitais, fazer intervenções clínicas ou cirúrgicas em indivíduos enfermos - tudo isso torna o médico um profissional mais propenso a se sentir desgastado física e psicologicamente ao longo da vida profissional. Em boa parte, a ação do médico envolve não só o paciente, como também o núcleo familiar deste, o que torna o profissional responsável e envolvido para além da técnica da medicina, extrapolando uma mera relaçăo consumidor-produtor.

Assumindo uma perspectiva sociológica, é correto afirmar que os médicos, desde sua formação, são socializados para se sentir responsáveis pela vida das pessoas que os procuram em busca de assistência médica. Treinados e acostumados a salvar vidas a qualquer custo, a estar disponíveis e aptos ao ofício a qualquer hora do dia - é bom lembrar que a omissão de socorro, segundo o Código de Ética Médica, é delito ético grave, passível de punição com perda do direito do exercício profissional -, os médicos acabam se tornando, na prática, 'guardiões da vida'. Estas são premissas sociológicas importantes para compreender o que se passa no cotidiano desse profissional, compreender seus dilemas, suas angústias e um certo 'sentimento de incapacidade' frente às adversidades.

Os dados da pesquisa garantem que essas sensaçōes de 'mal-estar' fazem parte da vida diária dos médicos, já que $80,4 \%$ declararam que a atividade médica é desgastante. ${ }^{4}$ A percepçăo de desgaste é semelhante nas diversas regiões do País, sendo o menor índice observado no Norte $(75,9 \%)$ e o maior $(83,0 \%)$ no CentroOeste. Chamam-nos a atenção as diferenças registradas nas taxas das unidades da Federação da região Norte, como, por exemplo, Pará $(68,7 \%)$, Rondônia $(83,2 \%)$ e Roraima $(85,8 \%)$. Tais diferenças, no entanto, não nos permitem tecer hipóteses explicativas fundamentadas em aspectos meramente geográficos (Tabela 6.1).

Embora nossa análise não se baseie num estudo longitudinal, há uma clara correlação entre percepção de desgaste e idade, ou seja, registra-se o percentual de $89 \%$ de médicos mais jovens, em fase de profissionalização e início de carreira. Esse percentual decresce à medida que os médicos se consolidam no mercado e atinge $48 \%$ dos médicos com mais de 60 anos, fase de paralisação progressiva das atividades (Gráfico 6.1).

4 À pergunta objetiva sobre desgaste ('sim' ou 'năo') seguia-se uma aberta, solicitando-lhes que explicassem as razóes que os levaram a declarar-se 'com' ou 'sem' desgaste. Neste item, os médicos năo se limitaram a informar apenas uma razăo, mas traçaram verdadeiros depoimentos das condiçōes em que exerciam a medicina. Assim, os cruzamentos que apresentaremos, bem como nossa análise, estarão comprometidos com uma visăo sociológica do desgaste profissional, nos isentando de qualquer inferência epidemiológica. 
Tabela 6.1 - Médicos distribuídos por desgaste profissional segundo Unidades da Federação. Brasil - 1995

\begin{tabular}{|c|c|c|c|c|c|c|}
\hline \multirow{2}{*}{$\begin{array}{l}\text { Unidades da } \\
\text { Federação }\end{array}$} & \multicolumn{2}{|c|}{ Sente desgaste } & \multicolumn{2}{|c|}{ Não sente desgaste } & \multicolumn{2}{|c|}{ Total* } \\
\hline & v. abs. & $(\%)$ & v. abs. & (\%) & v. abs. & (\%) \\
\hline REGIÃO NORTE & 4.251 & 75,9 & 1.348 & 24,1 & 5.599 & 100,0 \\
\hline Acre & 153 & 75,4 & 50 & 24,6 & 203 & 100,0 \\
\hline Amapá & 171 & 83,4 & 34 & 16,6 & 205 & 100,0 \\
\hline Amazonas & 1.104 & 84,1 & 208 & 15,9 & 1.312 & 100,0 \\
\hline Pará & 1.904 & 68,7 & 867 & 31,3 & 2.771 & 100,0 \\
\hline Rondônia & 416 & 83,2 & 84 & 16,8 & 500 & 100,0 \\
\hline Roraima & 121 & 85,8 & 20 & 14,2 & 141 & 100,0 \\
\hline Tocantins & 382 & 81,8 & 85 & 18,2 & 467 & 100,0 \\
\hline REGIÄO NORDESTE & 22.627 & 78,8 & 6.082 & 21,2 & 28.709 & 100,0 \\
\hline Alagoas & 1.669 & 74,7 & 565 & 25,3 & 2.234 & 100,0 \\
\hline Bahia & 6.560 & 76,3 & 2.038 & 23,7 & 8.598 & 100,0 \\
\hline Ceará & 3.044 & 82,9 & 628 & 17,1 & 3.672 & 100,0 \\
\hline Maranhão & 1.454 & 76,8 & 438 & 23,2 & 1.892 & 100,0 \\
\hline Paraíba & 2.272 & 78,9 & 606 & 21,1 & 2.878 & 100,0 \\
\hline Pernambuco & 4.662 & 83,7 & 909 & 16,3 & 5.571 & 100,0 \\
\hline Piauí & 821 & 79,0 & 218 & 21,0 & 1.039 & 100,0 \\
\hline Rio Grande do Norte & 1.180 & 72,3 & 451 & 27,7 & 1.631 & 100,0 \\
\hline Sergipe & 965 & 80,8 & 229 & 19,2 & 1.194 & 100,0 \\
\hline REGIĀO SUDESTE & 84.923 & 80,6 & 20.499 & 19,4 & 105.422 & 100,0 \\
\hline Espírito Santo & 2.876 & 83,6 & 564 & 16,4 & 3.440 & 100,0 \\
\hline Minas Gerais & 15.636 & 83,1 & 3.169 & 16,9 & 18.805 & 100,0 \\
\hline Rio de Janeiro & 19.982 & 75,5 & 6.479 & 24,5 & 26.461 & 100,0 \\
\hline São Paulo & 46.429 & 81,9 & 10.287 & 18,1 & 56.716 & 100,0 \\
\hline REGIÃO SUL & 22.588 & 81,4 & 5.154 & 18,6 & 27.742 & 100,0 \\
\hline Paraná & 7.251 & 83,6 & 1.419 & 16,4 & 8.670 & 100,0 \\
\hline Rio Grande do Sul & 11.541 & 78,9 & 3.082 & 21,1 & 14.623 & 100,0 \\
\hline Santa Catarina & 3.796 & 85,3 & 653 & 14,7 & 4.449 & 100,0 \\
\hline REGIÃO CENTRO-OESTE & 10.116 & 83,0 & 2.068 & 17,0 & 12.184 & 100,0 \\
\hline Distrito Federal & 3.781 & 81,7 & 847 & 18,3 & 4.628 & 100,0 \\
\hline Goiás & 3.644 & 84,7 & 659 & 15,3 & 4.303 & 100,0 \\
\hline Mato Grosso do Sul & 1.486 & 81,6 & 335 & 18,4 & 1.821 & 100,0 \\
\hline Mato Grosso & 1.205 & 84,1 & 227 & 15,9 & 1.432 & 100,0 \\
\hline BRASIL & 144.505 & 80,4 & 35.151 & 19,6 & 179.656 & 100,0 \\
\hline
\end{tabular}

* Um total de 3.396 médicos não declararam se sentem desgaste ou não com o exercício profissional.

Fonte: Pesquisa "Perfil dos Médicos no Brasil", Fiocruz/CFM. 
Tal correlaçăo sugere que a percepção do desgaste profissional está diretamente relacionada à história da vida profissional do médico: ${ }^{5}$ fase de 'iniciação' e 'afirmação' no mercado de trabalho, com intenso desgaste $(88,7 \%$ e $87,2 \%)$; período de 'consolidação' do trabalho $(81,2 \%)$ - de reconhecimento social; 'desaceleração' progressiva do trabalho $(69,7 \%)$; e a etapa de 'paralisaçăo' parcial ou total das atividades $(48,2 \%)$, na qual se pressupõe um comportamento cada vez mais seletivo das fontes laborais de tensão (Gráfico 6.1). Nossa argumentaçăo fundamenta-se na idéia de que a competitividade e a necessidade de conhecer e de se expor a diversas situações, funções e locais de trabalho são muito mais afetas aos médicos cuja posição laboral ainda năo está consolidada. Os profissionais com menos de dez anos no mercado (com até 34 anos de idade), por exemplo, estão mais sujeitos ao multiemprego (aceitando, inclusive, subempregos, salários inferiores à média etc.) e a trabalhar mais intensamente em regime de plantão, sendo ainda escassa sua clientela em consultório. Enfim, são médicos que, claramente, estão mais expostos à competitividade do mercado de trabalho.

\section{Gráfico 6.1 - Médicos distribuídos por desgaste profissional segundo faixa etária. Brasil - 1995}

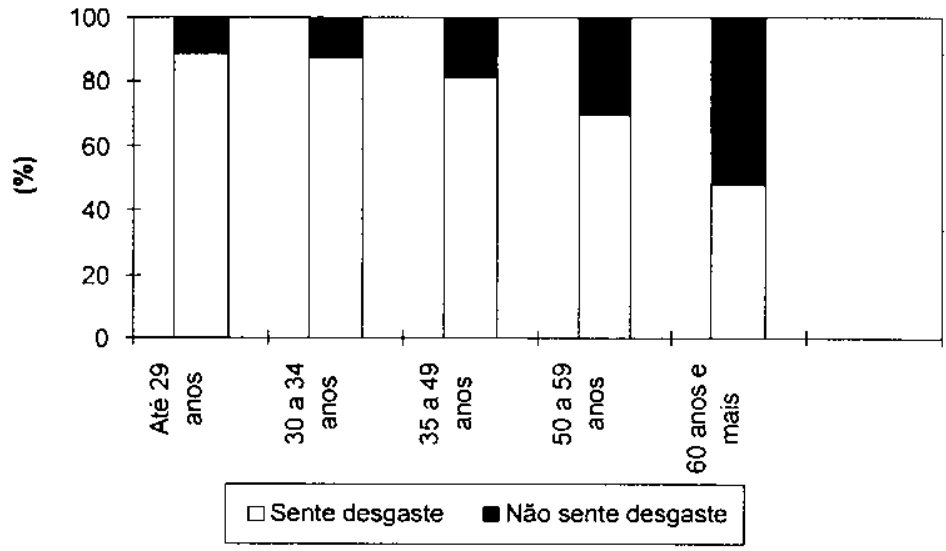

Fonte: Pesquisa "Perfil dos Médicos no Brasii", Fiocruz/CFM.

5 Neste trabalho, para analisar a trajetória evolutiva da vida profissional do médico no mercado de trabalho, adotamos a conceituação de 'f́ases': a) iniciação - médicos com até 29 anos; b) afirmação 30 a 34 anos; c) consolidaçāo - 35 a 49 anos; d) desaceleração - 50 a 59 anos; e e) paralisação das atividades - mais de 60 anos. 
A percepção de desgaste segundo gênero (Gráfico 6.2), embora seja semelhante, merece alguns comentários. Como vimos no capítulo 5 , as médicas, por motivos diversos, sofrem pressōes sociais mais agudas para desenvolver atividades na esfera pública. A sempre lembrada dupla jornada - lar e vida pública - não é apenas uma figura da retórica feminista. As atividades no lar, os encargos intransferiveis da procriação, os obstáculos e preconceitos sociais são alguns dos fatores que podem contribuir para que a mulher sofra maior desgaste no mundo do trabalho. Os entraves para exercer certas especialidades, para prolongar ainda mais a jornada de trabalho, para assumir cargos diretivos representam dificuldades adicionais para a plena integraçăo da médica no trabalho e para a consolidação de sua carreira. Certamente, representam fontes de desgaste, de estresse, além de contribuírem para gerar um sentimento de incapacidade frente às diversidades ambientais.

\section{Gráfico 6.2 - Médicos que declararam desgaste profissional distribuídos por gênero. Brasil - 1995}
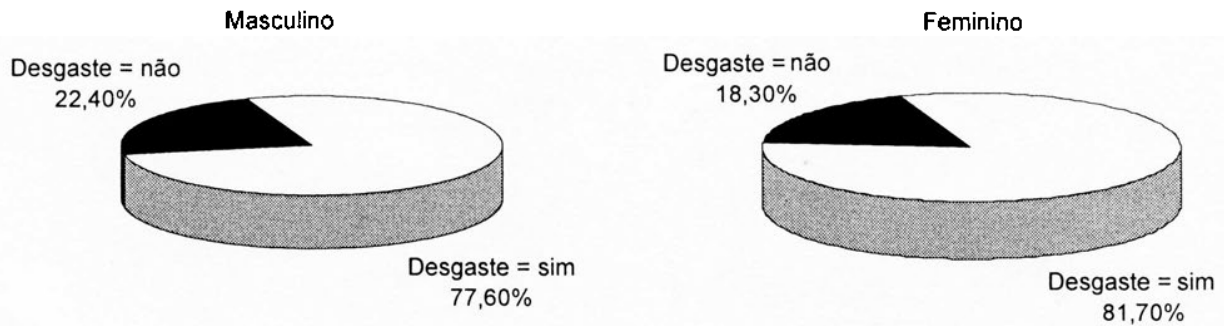

Fonte: Pesquisa "Perfil dos Médicos no Brasil", Fiocruz/CFM.

\section{OS MÉDICOS FALAM DE SEU DESGASTE}

Apenas um pequeno contingente de médicos $(19,6 \%)$ afirmou năo sentir desgaste no exercício profissional. Apesar disso, julgamos interessante apresentar as razões pelas quais eles năo sentem esse problema. As mais freqüentes foram: (a) satisfação profissional e amor à profissão $(40 \%)$; (b) boas condições de trabalho, com recursos humanos e materiais adequados (15\%) e (c) atividade profissional equilibrada (programada), não requerendo múltiplos vínculos empregatícios (9\%).

Como veremos em seguida, tais razóes, quase sempre, representam a antítese daquelas que justificaram o desgaste. Isto não significa, para nos determos na razão mais freqüente, que estes médicos têm maior adesão ao ideal profissional de serviço. Esta adesão, como expusemos no capítulo 1, é característica de algumas profissões (Larson, 1977:58-59), e, certamente, a profissão médica está incluída entre as 
que apresentam intensamente esse traço. Amor à profissão e satisfação em exercer o ofício da medicina sāo elementos presentes na quase totalidade dos médicos entrevistados, mas acabam ficando encobertos em razão da realidade adversa a que a maioria está submetida. Na verdade, o que efetivamente conta nessa análise é o fato de que poucos são os médicos que não expressam desgaste no exercício profissional. Hoje, no Brasil, existem reduzidas condiçōes adequadas para 'seguir' a carreira de medicina.

Os principais motivos alegados para o desgaste foram: excesso de trabalho, jornada de trabalho prolongada, multiemprego (27\%); baixa remuneração $(17 \%)$; más condiçōes de trabalho (16\%); área de atuação/especialidade $(9 \%)$; excesso de responsabilidade, relação de vida e morte com os pacientes (12\%) (Gráfico 6.3). 6

Antes de explorar as justificativas oferecidas pelos médicos, convém contextualizá-las em relação a alguns aspectos de nosso sistema de saúde. Como assinala Veras (1991:65-66),

a estrutura do sistema de saúde brasileiro se define pela existência de grande variedade de tipos de serviços que se diferenciam segundo o tipo de financiamento, a natureza jurídica, a estrutura gerencial, as formas de pagamento e o modo de organização da prática médica. É um sistema plural onde o Estado atua tanto como provedor de serviços (serviços públicos), como financiador de serviços prestados pelo setor privado (setor privado dependente). Existem também os serviços privados que operam com base nas leis de mercado, tais como: os consultórios de médicos liberais, as empresas médicas e os seguros-saúde.

6 a) excesso de trabalho/multiemprego: agrega os códigos jornada de trabalho elevada, disponibilidade integral, '24 horas no ar', dedicação contínua, pouco lazer, pouco contato com a família, 'não há hora para parar' etc.; b) más condições de trabalho: agrega os códigos falta de material, falta de recursos humanos, pessoal não-qualificado, trabalho com improvisação, aumento exagerado da demanda devido à socialização da medicina e inadequada alocação de recursos disponiveis, além da escassez de médicos atuando, provocando sobrecarga de trabalho; c) área de atuaçāo/ especialidade: agrega os códigos atuar em plantão, emergência, UTI, escolha da especialidade, especificidades da especialidade, necessidade de aperfeiçoamento e estudo contínuo exigido pela função exercida; d) relação médico-paciente: agrega os códigos relaçāo de envolvimento emocional com o problema do paciente, impotência/limitação do médico frente às condiçōes de vida precárias do enfermo, exposição a casos em que não possui condiçōes de auxifiar; e) conflito e cobrança da população: agrega os códigos cobranças/julgamento dos pacientes/população geral, trabaiho pouco reconhecido, pouco respeitado, marginalizado, manipulação da opinião pública contra o médico, via imprensa; f) perda da autonomia: agrega os códigos interferências políticas, questōes de políticas de saúde, também através das políticas públicas, conflitos gerenciais, problemas na organização do trabalho, preenchimento de um excessivo número de papeletas de controle, responsabilidade com a burocracia do serviço, e, ainda, por problemas burocráticos.

Como já foi dito, estas categorias agregam códigos atribuídos por nós a mais de vinte mil respostas oferecidas pelos médicos. Destaque-se a grande identidade entre estas respostas e as categorias (teóricas) mediadoras utilizadas nos diversos estudos citados. 


\section{Gráfico 6.3 - Motivos de desgaste profissional.* Brasil - 1995}

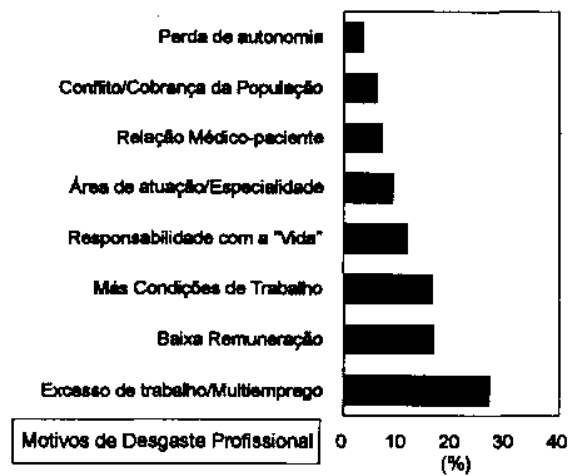

* Cada médico poderia declarar mais de um motivo.

Fonte: Pesquisa "Perfil dos Médicos no Brasil", Fiocruz/CFM.

O conjunto das áreas de atuação médica de cada setor delineia padrões distintos de comportamento de seus trabalhadores, por exemplo, quando a estrutura gerencial impõe limites à autonomia médica de tomar decisōes em relação aos pacientes. Isto gera problemas na relação com o paciente e se reflete na percepção de desgaste do médico. A análise da relação existente entre percepção de desgaste e tipo de inserção no mercado está, entretanto, prejudicada pela multiplicidade de vínculos que é habitual da categoria, pautada por diferentes especialidades e setores de atuação. O socorrista de uma emergência pública pode ser plantonista de uma UTI de uma instituição privada e cardiologista e/ou clínico geral em seu consultório. A Tabela 6.2 mostra que tanto o médico que atua exclusivamente em determinado setor (público ou privado) como aquele que só faz consultório sofrem desgaste. Mas por que tal fenômeno acontece? Por que o médico que atua exclusivamente em consultório sofre tanto desgaste quanto aquele que está inserido como assalariado numa estrutura pública ou privada?

Tabela 6.2 - Médicos que declararam desgaste profissional segundo setor de atuação. Brasil - 1995

\begin{tabular}{lc}
\hline \multicolumn{1}{c}{ Setor de atuação } & $(\%)$ \\
\hline Público & 84,5 \\
Privado & 83,2 \\
Consultório & 79,3 \\
Público, privado e consultório & 86,9 \\
\hline
\end{tabular}

Fonte: Pesquisa "Perfil dos Médicos no Brasil", Fiocruz/CFM. 


\section{Mëdico '24 horas no ar'}

$\mathrm{Na}$ opinião dos médicos, ter vários empregos e, portanto, estar submetido a diversas situaçōes de trabalho representa uma fonte importante de desgaste, relacionada, assim, com a intensidade da atividade ( $27 \%)$. Neste grupo, incluemse como fontes de desgaste mais apontadas pelos médicos a multiplicidade de vínculos profissionais (Tabela 6.3), a necessidade de trabalhar em município diferente daquele onde residem (Gráfico 6.4) e a falta de tempo adequado para o lazer e o descanso.

Tabela 6.3 - Médicos por desgaste profissional segundo número de atividades. Brasil - 1995

\begin{tabular}{|c|c|c|c|c|c|c|c|c|}
\hline \multirow{2}{*}{$\begin{array}{l}\text { Número de } \\
\text { atividades }\end{array}$} & \multicolumn{2}{|c|}{ Sente desgaste } & \multicolumn{2}{|c|}{$\begin{array}{l}\text { Não sente } \\
\text { desgaste }\end{array}$} & \multicolumn{2}{|c|}{ Ignorado } & \multicolumn{2}{|c|}{ TOTAL } \\
\hline & v. abs. & (\%) & v. abs. & $(\%)$ & v. abs. & $(\%)$ & v. abs. & $(\%)$ \\
\hline Uma & 20.187 & 64,9 & 9.908 & 31,8 & 1.020 & 3,3 & 31.115 & 100,0 \\
\hline Duas & 38.737 & 77,9 & 10.706 & 21,5 & 312 & 0,6 & 49.755 & 100,0 \\
\hline Três & 45.128 & 83,5 & 8.564 & 15,9 & 328 & 0,6 & 54.020 & 100,0 \\
\hline Quatro & 25.017 & 88,1 & 3.207 & 11,3 & 177 & 0,6 & 28.401 & 100,0 \\
\hline Cinco ou mais & 13.650 & 90,0 & 1.291 & 8,5 & 221 & 1,5 & 15.162 & 100,0 \\
\hline TOTAL* & 142.719 & 80,0 & 33.676 & 18,9 & 2.058 & 1,2 & 178.453 & 100,0 \\
\hline
\end{tabular}

* A diferença observada do total geral de médicos (183.052) refere-se a médicos aposentados, afastados, desempregados e aos que não declararam.

Fonte: Pesquisa "Perfil dos Médicos no Brasil", Fiocruz/CFM.

O desgaste é mais referido entre os que trabalham num município diferente daquele onde residem, o que implica deslocamentos freqüentes. Da mesma forma, ao se observar a referência a desgaste e a multiplicidade de vínculos profissionais, tem-se uma relação de proporcionalidade direta, ou seja, quanto maior o número de atividades, maior o desgaste, apresentando este sintoma em grau mais elevado aqueles que têm quatro ou mais atividades.

O cansaço físico e mental acompanha a vida diária de cada médico, em especial daqueles que atuam diretamente na assistência, o que lhes dá a sensação de estar '24 horas no ar':

Ansiedade a que o médico está sujeito (como profissional da 'ajuda'). Sempre cobram 'dedicação exclusiva'. Somos médicos 24 horas por dia, mesmo não estando de plantão em local de trabalho. (clínico geral, masculino, 33 anos, MG) 
Não há 'fim de expediente'. Não há feriado, fim de semana ou noite de sono. É uma espécie de plantão permanente. (ginecologista, masculino, 43 anos, RS)

\section{Gráfico 6.4 - Médicos distribuídos por residência em município diferente do qual trabalha segundo desgaste profissional. Brasil - 1995}

Trabalha em munciplo diferente

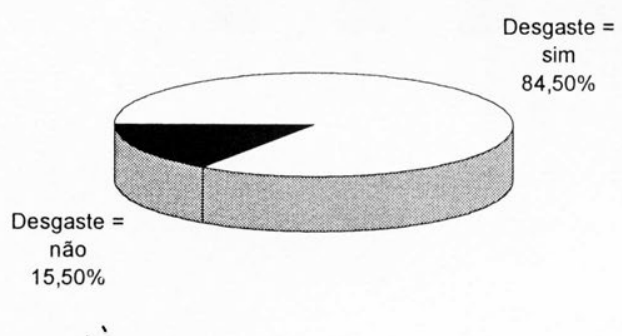

Trabalha no mesmo municipio

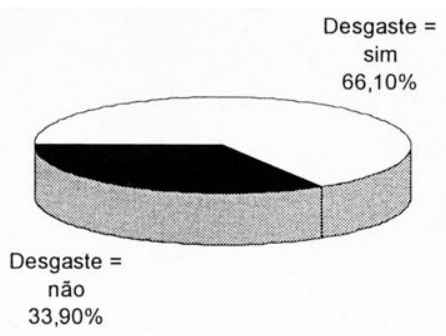

Fonte: Pesquisa "Perfil dos Médicos no Brasil", Fiocruz/CFM.

\section{Trabalhar muito e ganhar pouco}

De modo geral, ao analisarmos comparativamente o mercado de trabalho especializado, associamos salários mais baixos e jornadas prolongadas aos profissionais que estão em início de carreira. A pesquisa permite constatar este fato especialmente se correlacionarmos esses fatores com o desgaste sofrido na vida diária do médico. Como já mencionado, os novatos experimentam um cotidiano de trabalho mais extenuante em conseqüências das jornadas prolongadas, plantões, clientela particular escassa e convênios que pagam menos por procedimentos. Enfim, diversos fatores nos induzem a pensar que a relação encontrada entre renda e desgaste (Gráfico 6.5) condiz com o exposto acima.

Alie-se a isto o sentimento de não ser valorizado e de ter perdido o status, sentimento que está fortemente relacionado aos baixos salários e à pequena remuneração conferida ao médico. Mas não apenas os novatos amargam uma remuneração incompatível com a representação social da profissão.

O respeito pelo profissional está em extinção. Salários humilhantes. (pediatra, masculino, 48 anos, $\mathrm{GO}$ )

O médico perdeu a noçăo de seu próprio valor e submete-se a uma condição indigna de sua importância para a sociedade. Deve reaprender o significado de sua 'arte-profissão' e ser remunerado à altura que the corresponde. (oftalmologista, masculino, 42 anos, SC) 


\section{Gráfico 6.5 - Médicos que declararam desgaste profissional segundo renda mensal. Brasil - 1995}

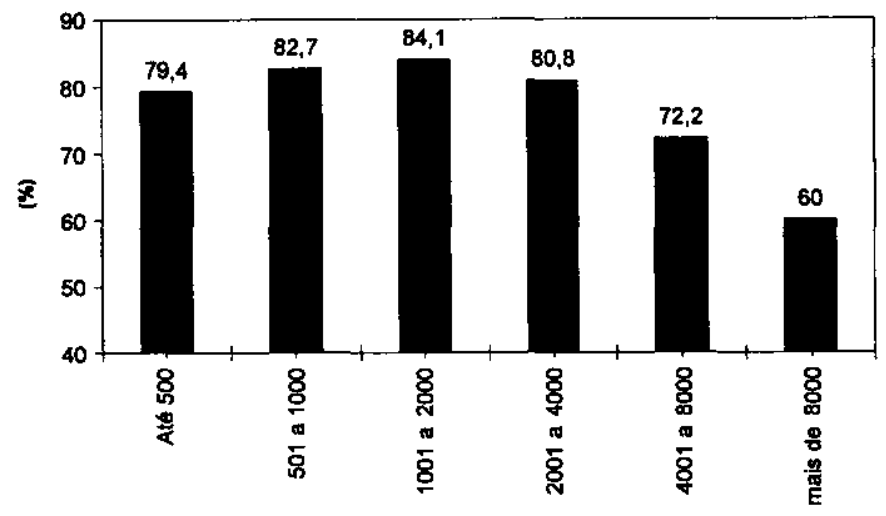

Renda mensal deciarada (em dólares)

Fonte: Pesquisa "Perfil dos Médicos no Brasil", Fiocruz/CFM.

Sobrecarga de atendimentos devido à baixa remuneração e à alta taxa de retorno não-remunerado no consultório. (pediatra, feminino, 38 anos, SP)

As correlações entre aumento da jornada de trabalho e multiemprego estão freqüentemente relacionadas com a necessidade de o médico manter um certo padrāo social de consumo, submetendo-se a vários empregos por salários que, muitas vezes, estão bem aquém do desejado.

Trabalho mais de dez horas por dia, para poder pagar contas e sobreviver. (neuropediatra, feminino, 38 anos, PA)

Tenho vários empregos para conseguir uma renda mínima mènsal de sobrevivência. Atendo aos pacientes em pé para poder dar tempo (...) Às vezes, tenho que comprar pilha para equipamentos do posto porque o serviço não oferece. (pediatra, feminino, 35 anos, MT)

Más condiçōes de trabatho: impedimento do exercicio profissional

Uma das razões para o desgaste mais alegadas pelos médicos está associada às más condições de trabalho. Uma conjuntura política caracterizada pela redução dos investimentos em políticas sociais, racionalização dos custos, maior adequação entre custo-benefício e redução de pessoal auxiliar tem sido apontada como fonte importante de insatisfação dos profissionais da saúde que trabalham em instituições de saúde públicas ou privadas. Em muitos casos, a falta de recursos humanos ade- 
quados tem gerado sobrecarga de trabalho e responsabilidade, obrigando os médi$\cos$ a responder por áreas que estão além de sua estrita responsabilidade.

Por que tenho de me dividir entre atividades de ambulatório, plantão e gerenciamento em um local onde os recursos humanos são escassos?. (clínico geral, masculino, 34 anos, ES)

Trabalhamos com vidas, seres humanos, cada qual envolto em problemáticas diversas, exigindo do médico raciocínio rápido, porém nossa baixa remuneração nos leva a trabalhar em excesso, sob condiçōes adversas, como falta de recursos humanos e materiais, e daí o estresse. (pediatra, feminino, 45 anos, $\mathrm{PE}$ )

Como dirigente hospitalar (hospital do SUS), a receita não dá para as despesas, e a entidade está sujeita a fechamento. (administrador hospitalar, feminino, 47 anos, SP)

Há total falta de condiçōes de atendimento. Falta tudo! Até um antitérmico. (pediatra, feminino, 48 anos, CE)

Mesmo em condições precaríssimas, os médicos são levados a acreditar que terão que tomar decisões técnicas corretas sobre o paciente, ainda que estas estejam expostas a constrangimentos devido a fatores ambientais, externos à sua ação técnica. Assim, eles julgam que têm:

Responsabilidade frente à vida do proximo. Complexidade e responsabilidade de decisão do ato médico. (clínico geral, feminino, 51 anos, MA)

E protestam diante das circunstâncias:

$O$ 'sofrimento' da decisão terapêutica é agravado pela falta de materiais. A sobrevivência exige regime de trabalho absurdo. (obstetra, masculino, 39 anos, SP)

Nestas circunstâncias, são inúmeros os médicos que não acreditam mais que o trabalho possa ser realizado. Numa associação correta entre exercício profissional e ambiente, eles acabam elaborando severas críticas ao ambiente hostil que circunda seu cotidiano:

Excluindo o cansaço físico por trabalho noturno e finais de semana, o médico tem de 'tentar' contornar problemas sociais, condiçōes de trabalho precárias, paciente que nāo tem condição de adquirir medicaçāo, dificuldade para internar, faltam vagas, dificuldade de investigação com exames complementares, caros e pouco disponíveis quando feitos pelo SUS; e o mais grave atualmente e que causa estresse é o problema que enfrentamos com as queixas e processos judiciais, nos quais, muitas vezes, o que levou à má evolução de algum caso clínico é um conjunto de fatores que foge ao nosso alcance individual de resolução: primeiro, excesso de trabalho, que reduz a nossa capacidade de raciocínio; segundo, pacientes imunodeprimidos, desnutridos, com doenças crônicas, anemias etc.; terceiro, enfermagem mal preparada; quarto, demora que o paciente encontra para conseguir atendimento; quinto, bombardeio de noticias negativas 
sobre a classe médica, alguns pacientes nos vendo como culpados por seu infortúnio na evolução de uma patologia, até prova em contrário. (pediatra, feminino, 34 anos, PR)

Porque o médico está deixando de ser um profissional liberal para ser funcionário público de um sistema falido e sem respaldo (ético e social) de entidades médicas. (cirurgiâo geral, masculino, 50 anos, MT)

Outros adotam o lema de não se 'contaminar' com os constrangimentos ambientais:

Estabeleci um regime de desaceleração progressiva chamado $P A$, que é Profilaxia da Aporrinhação. (otorrinolaringologista, masculino, 59 anos, SC)

Segundo Machado, a perda da autonomia técnica é associada às más condiçóes de trabalho. Aquela, por sua vez, atua como determinante de mudanças na relação médico-paciente. Uma vez que a diminuição do poder de decisão sobre a conduta médica limita a eficiência/eficácia do trabalho, a credibilidade do profissional e a confiança do paciente é que são abaladas. Desta forma, o conflito entre a 'racionalidade gerencial' das instituiçōes e os preceitos típicos ideais da conduta médica gera um posicionamento negativo do paciente no tocante à deferência devida à expertise do médico - deterioração da relação de confiança do paciente. Ou seja,

as exigências da profissão são sacrificadas à lógica burocrática da organização, que requer prestação de contas de atos, procedimentos e condutas técnicas num permanente processo de controle sobre a atividade do médico ao molde do que ocorre com a burocracia americana através dos DRGs (Diagnostic Related Groups). (Machado, 1996:163)

Por outro lado, cada vez mais a clientela reivindica a responsabilidade penal dos profissionais. Ainda segundo essa autora,

a clientela exige explicações detalhadas dos procedimentos a serem adotados em seu caso particular e busca também não só compreender, mas certificar-se de que está sendo atendida corretamente. Em muitos casos, e em número crescente, estes clientes chegam a penalizar judicialmente os profissionais faltosos. (p.67-68)

Estas situações de penalização têm se tornado mais freqüentes. Nesse mesmo trabalho, depoimento de um líder sindical elucida bem a questão:

Os médicos estão, por exemplo, fazendo sutura, improvisando tubos de soro como fios de sutura. Chegou um caso aqui (sindicato dos médicos) na.semana passada, que tratava disso, de uma sutura de um braço feita com tubo de soro fisiológico, porque não havia fio de sutura no hospital. Há três dias atrás uma companheira nossa teve uma amiga que foi ter filho em uma maternidade pública. Ela teve que ficar esperando duas horas para fazer indução do seu parto porque o médico foi em casa buscar fio de sutura dele, pois estava em falta no hospital. Quando ele chegou, a criança já estava morta. Então, isso está acontecendo e as condiçōes são as piores possiveis. O médico está responden- 
do a processo no Conselho Regional de Medicina, porque a família identifica na figura do médico a culpa de tudo (médico, lider sindical, 53 anos). (Machado, 1996:173)

\section{Com a vida e a morte nas māos}

Até agora, observamos que as razōes alegadas para o desgaste estavam associadas fundamentalmente a causas externas à profissão. Consideremos, então, como os médicos se referiram a um dos aspectos essenciais de sua profissão - lidar com a vida e a morte de terceiros como ator principal numa situação concreta. A noção de responsabilidade pela vida do paciente, a permanente necessidade de decidir sobre a vida de outrem traz conseqüências paradoxais: por um lado, o sentimento de fazer parte de uma 'casta de eleitos', que tem poder sobre outra pessoa, e de ser o profissional central do sistema de saúde, o que, em geral, satisfaz o médico; por outro, esta mesma imagem o expōe a críticas e a acusações pelo não-funcionamento dessa engrenagem, o que o torna vulnerável num contexto desfavorável, como é o sistema de saúde brasileiro.?

Atualmente, o médico do pronto-socorro vive um momento de grande angústia. Além de atender, deve decidir quem vai ter direito à vida, devido à falta de vagas nos hospitais de emergência. Esta 'onipotência' é por demais desgastante. (cirurgião geral, masculino, 37 anos, ES)

Péssimas condiçōes de trabalho, descaso das autoridades para com o senviço, nos colocando em choque com a população que não encontra o serviço (atendimento) que necessita. (obstetra, masculino, 38 anos, MA)

Alta responsabilidade com a vida alheia. Baixa remuneração. Pressão do paciente, do poder público e dos donos dos hospitais. (dermatologista, masculino, 47 anos, PR)

Assumindo a posição de que os médicos são os responsáveis pelo estado de deterioração em que se encontra boa parte das instituições de saúde do País, a população usuária acaba estabelecendo uma relação de estranhamento entre médico e paciente. Ficam pouco à vontade os usuários e os médicos:

A população cobra do médico que este seja quase um 'semideus', dono de um saber infalivel, mas não é bem assim, somos humanos e por isso limitados. (ginecologista, masculino, 35 anos, MS)

Porque em virtude da opiniảo pública já ter um posicionamento conttrário ao médico, devido à demora ou não acesso ao atendimento, já chega brigando. (cardiologista, masculino, 40 anos, ES)

7 Para um interessante paralelo com trabalhadores na indústria, ver: DejOURS \& JAYET (1994). 
O sistema (SUS) levou o médico a uma condição de desprestigio, perdendo sua 'postura honrosa', passando a ser maltratado e até ameaçado pelo cliente como sendo o 'testa-de-ferro' do sistema. (clínico geral, masculino, 51 anos, MA)

\section{ESCOLHA PROFISSIONAL: UMA FONTE DE DESGASTE?}

A função que o médico ocupa numa estrutura organizacional, seja numa instituição de saúde hospitalar ou ambulatorial, seja em seu consultório, altera a forma, a percepção e a intensidade do desgaste de seu trabalho. Funções como, por exemplo, a de plantão (Gráfico 6.6) são apontadas pelos médicos como causadoras de estresse e desgaste.

\section{Gráfico 6.6 - Médicos distribuídos por atuação em plantão segundo desgaste profissional. Brasil - 1995}

\section{Faz plantão}

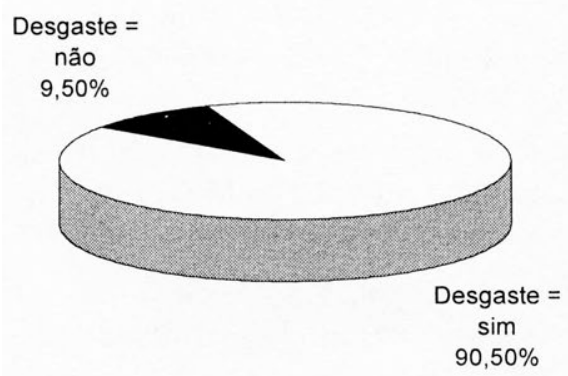

Não faz plantão

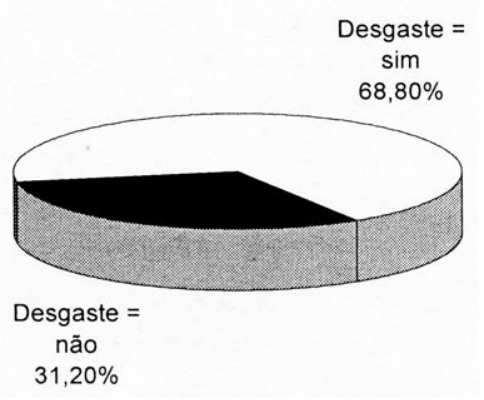

Fonte: Pesquisa "Perfil dos Médicos no Brasil", Fiocruz/CFM.

Os dados da (Tabela 6.4) sugerem algumas considerações: a) a atividade de plantonista é a que mais explicita o impacto do desgaste, já que $91 \%$ dos profissionais que fazem plantão percebem a atividade como desgastante, seja qual for a função em que atuem - emergência, pronto-socorro, enfermaria, UTI etc. - e seja qual for o setor de atuação (público ou privado); b) o desgaste é menos frequüente nas funções ligadas à atividade de 'rotina', especialmente nas instituiçōes privadas; c) pela natureza da função, a residência é uma fonte de desgaste, pois é o momento profissional em que o médico se submete a jornadas prolongadas de trabalho e a inúmeros plantões, que sobrecarregam seu cotidiano e d) fazer parte do staff técnico-burocrático ou exercer a função de docência, estando o médico no setor público ou privado, causam menor desgaste. 
Tabela 6.4 - Médicos que deciararam desgaste profissional segundo funções desempenhadas nos setores público e privado. Brasil - 1995

\begin{tabular}{|c|c|c|c|c|}
\hline \multirow[b]{2}{*}{ Funções } & \multicolumn{2}{|c|}{ Setor público } & \multicolumn{2}{|c|}{ Setor privado } \\
\hline & (\%) & $\begin{array}{c}\% \text { de } \\
\text { desgaste } \\
\text { na faixa* }\end{array}$ & $(\%)$ & $\begin{array}{c}\% \text { de } \\
\text { desgaste } \\
\text { na faixa* }\end{array}$ \\
\hline \multicolumn{5}{|l|}{ Plantonista } \\
\hline Emergência/pronto-socorro & 14,8 & 93,1 & 10,3 & 95,7 \\
\hline Maternidade & 4,5 & 94,4 & 4,4 & 95,8 \\
\hline Enfermaria & 2,1 & 95,9 & 3,0 & 89,4 \\
\hline UTI & 3,1 & 88,8 & 4,8 & 93,9 \\
\hline Ambulatório/pronto-atendimento & 4,8 & 87,9 & 5,3 & 88,6 \\
\hline Serviço de apoio terapêutico/diagnóstico & 1,3 & 80,5 & 2,5 & 95,0 \\
\hline \multicolumn{5}{|l|}{ Rotinas } \\
\hline Emergência/pronto-socorro & 1,4 & 90,2 & 2,1 & 83,1 \\
\hline Enfermaria & 6,4 & 88,4 & 9,5 & 83,8 \\
\hline Ambulatório/pronto-atendimento & 25,7 & 87,6 & 26,1 & 81,8 \\
\hline UTI & 0,8 & 76,7 & 1,1 & 76,8 \\
\hline Maternidade & 0,6 & 83,1 & 1,7 & 90,2 \\
\hline Serviço de apoio terapêutico/diagnóstico & 8,1 & 81,0 & 16,6 & 79,6 \\
\hline \multicolumn{5}{|l|}{ Residência } \\
\hline Cirurgia/Espec. cirúrgica & 2,2 & 94,5 & 0,7 & 89,5 \\
\hline Clínica/Espec. clínica & 2,8 & 89,3 & 1,0 & 78,9 \\
\hline Serviço de apoio terapêutico/diagnóstico & 0,4 & 85,9 & 0,2 & 88,0 \\
\hline \multicolumn{5}{|l|}{ Outras } \\
\hline Gestão (chefia/direção) & 7,9 & 82,6 & 7,4 & 73,7 \\
\hline Saúde pública & 5,8 & 82,1 & 0,7 & 86,7 \\
\hline Docentes & 6,3 & 73,0 & 2,5 & 81,4 \\
\hline TOTAL & 100,0 & 86,3 & 100,0 & 85,1 \\
\hline
\end{tabular}

* O percentual de desgaste na faixa representa o percentual de médicos que declararam desgaste por funçöes desempenhadas no especfíco setor.

Fonte: Pesquisa "Perfil dos Médicos no Brasil", Fiocruz/CFM. 
Em seu estudo sobre sofrimento psíquico num hospital público federal no Rio de Janeiro, Palácios (1993:10) mostra que

As diferentes inserçöes no processo de trabalho em saúde, a falta de controle sobre a atividade desempenhada, a falta de sentido das tarefas, o isolamento social e o 'distanciamento de si' são os principais fatores que determinam a diversidade de niveis de sofrimento psíquico, nas diferentes áreas de trabalho do hospital geral estudado.

Aponta ainda um maior índice de sofrimento entre aqueles que trabalhavam sob regime de plantão e, entre os médicos, nos que atuavam no setor de emergência.

Ainda neste grupo de respostas, estão as questōes relacionadas com as especialidades exercidas pelos médicos e sua percepção de desgaste. ${ }^{8}$ Ao se analisar sobre a escolha profissional (especialidade) e desgaste, fatos extremamente relevantes advêm das singularidades dos diversos "tipos de práticas" da medicina. Neste contexto, emergem distintos grupamentos de médicos especialistas, que experimentam o desgaste do trabalho de forma mais ou menos intensa (Tabela 6.5).

Tabela 6.5 - Médicos que declararam desgaste profissional segundo especialidade principal. Brasil - 1995

\begin{tabular}{lc}
\hline \multicolumn{1}{c}{ Especialidade principal } & (\%) \\
\hline Hansenologia & 97,7 \\
Hemoterapia & 96,6 \\
Cirurgia da māo & 95,8 \\
Nefrologia & 95,6 \\
Mastologia & 95,3 \\
Reumatologia & 94,5 \\
Pneumologia & 93,3 \\
Neurocirurgia & 93,1 \\
Anestesiologia & 92,4 \\
Ortopedia e Traumatologia & 91,0 \\
Geriatria e Gerontologia & 90,7 \\
Hematologia & 90,7 \\
Tisiologia & 90,5
\end{tabular}

8 Vale ressaltar que serão necessários estudos que façam a devida correlação entre desgaste, estresse e sofrimento mental e especialidade médica, para que possamos, de fato, analisar corretamente este importante aspecto do mundo do trabalho. 
Tabela 6.5 - Médicos que declararam desgaste profissional segundo especialidade principal. Brasil - 1995 (continuação)

\begin{tabular}{|c|c|}
\hline Especialidade principal & $(\%)$ \\
\hline Cancerologia & 90,4 \\
\hline Neurofisiologia clínica & 89,6 \\
\hline Alergia e Imunoterapia & 88,6 \\
\hline Cirurgia pediátrica & 85,3 \\
\hline Medicina interna & 85,0 \\
\hline Pediatria & 84,7 \\
\hline Endocrinologia e Metabolia & 84,4 \\
\hline Cirurgia geral & 84,3 \\
\hline Terapia intensiva & 84,3 \\
\hline Angiologia & 83,9 \\
\hline Gineco-Obstetrícia & 84,0 \\
\hline Cardiologia & 83,1 \\
\hline Cirurgia de cabeça e pescoço & 82,0 \\
\hline Infectologia & 80,9 \\
\hline Urologia & 80,8 \\
\hline Cirurgia vascular & 78,7 \\
\hline Neurologia pediátrica & 76,9 \\
\hline Patologia & 76,9 \\
\hline Medicina sanitária & 76,5 \\
\hline Dermatologia & 75,8 \\
\hline Cirurgia cardiovascular & 75,7 \\
\hline Citopatologia & 75,3 \\
\hline Medicina geral comunitária & 75,1 \\
\hline Gastroenterologia & 73,9 \\
\hline Proctologia & 73,0 \\
\hline Otorrinolaringologia & 71,9 \\
\hline Medicina do trabalho & 70,0 \\
\hline Cirurgia torácica & 69,7 \\
\hline Psiquiatria & 69,4 \\
\hline Cirurgia plástica & 68,8 \\
\hline Administração hospitalar & 68,4 \\
\hline Endoscopia digestiva & 67,6 \\
\hline
\end{tabular}


Tabela 6.5 - Médicos que declararam desgaste profissional segundo especialidade principal. Brasil - 1995 (continuação)

\begin{tabular}{lc}
\hline \multicolumn{1}{c}{ Especialidade principal } & $(\%)$ \\
\hline Homeopatia & 67,0 \\
Neurologia & 65,1 \\
Medicina legal & 65,1 \\
Oftalmologia & 64,6 \\
Medicina esportiva & 64,4 \\
Radiologia & 64,2 \\
Patologia clínica & 62,9 \\
Broncoesofagologia & 60,5 \\
Nutrologia & 41,7 \\
Eletroencefalografia & 41,1 \\
Radioterapia & 40,9 \\
Medicina nuclear & 33,7 \\
Genética clínica & 24,2 \\
Fisiatria & 10,4 \\
Medicina de tráfego & 9,1 \\
\hline TOTAL* & 78,9 \\
\hline
\end{tabular}

* Ao total incluiu-se 1.918 ignorados e 501 médicos de outras especialidades.

Fonte: Pesquisa "Perfil dos Médicos no Brasil", Fiocruz/CFM.

Quais seriam as especialidades que mais vivenciam esse desgaste?

São 14 as especialidades cujos praticantes, em proporçōes acima de $90 \%$, expressaram o problema nos depoimentos - ou seja, estão se sentindo pressionados, desgastados, estressados. Mas o que teriam a hansenologia, a tisiologia, a geriatria, a anestesiologia ou mesmo a nefrologia ou a cancerologia em comum? Parece-nos importante refletir sobre alguns aspectos. Primeiro, quase todas essas especialidades lidam com doenças crônicas, nas quais as possibilidades de 'cura' efetiva não dependem exclusivamente do médico ou são apenas remotas (cancerologia, nefrologia, reumatologia, hematologia e hansenologia, por exemplo). Neste grupo, o sentimento de impotência pode ser o predominante, seja pelas dificuldades em obter medicamentos para os portadores da hanseníase, seja pela indisponibilidade de órgãos para transplante ou pelo inexorável processo de morte decorrente de algumas neoplasias malignas. 
Outro aspecto a destacar é a relação de algumas dessas especialidades com as deformaçōes e os estigmas sociais, referentes às próprias patologias das quais se encarregam a hansenologia, geriatria, tisiologia e reumatologia, por exemplo, ou a cirurgia mutiladora (mastologia). Na maioria delas, pode-se dizer que há um ciclo de acompanhamento, pelo médico, do lento sofrimento do paciente, que, em geral, não leva à cura. Neste contexto, o profissional assiste à 'deterioração' do enfermo, sem ter muito a fazer. O sucesso da cura, nestes casos, é um componente pouco presente para o médico, o paciente e seus familiares. Entre os mais desgastados deste grupo estão os anestesistas, que, paradoxalmente, também lidam com a vida e a morte. $\mathrm{O}$ ato da anestesia, apesar de altamente tecnificado e padronizado, constitui, por natureza, a retirada e o retorno do paciente à vida. Embora não seja possivel excluir quaisquer hipóteses, o quadro apresentado para algumas dessas especialidades sugere que outros fatores já apontados - idade, condiçōes de trabalho etc. - podem contribuir para a maior freqüência de desgaste entre seus praticantes.

Em posição diametralmente oposta situa-se o grupamento de médicos especialistas que demonstram menos desgaste em seu cotidiano. Encontram-se nessa situaçāo os especialistas em apoio diagnóstico e imagens (genética clínica, eletroencefalografia, radiologia, patologia clínica), especialidades nas quais a relaçăo médicopaciente é mediada por pedidos e recomendações de outro colega médico, que, em última instância, é o responsável direto pelo paciente encaminhado ao diagnóstico. Săo especialidades onde o controle do processo de trabalho é exercido mais plenamente pelo médico, e os resultados do trabalho são mais 'perceptíveis' - a realização de um exame e a emissão de seu laudo.

Vale destacar, ainda, o importante papel das especialidades cirúrgicas, que, em sua maioria, criam um grupo homogêneo de percepção de desgaste. Embora năo se encontre no mesmo grau do grupo de médicos que lidam diretamente com o paciente crônico, ainda assim destacam-se com $85 \%$. Mais uma vez, é importante reportar-se ao seu processo de trabalho, pois é nele que possivelmente serăo encontradas as principais correlaçōes com o desgaste. Entre os cirurgiōes, a indisponibilidade de tempo, o trabalho manual por longos períodos em posição desconfortável e a grande dependência em relação a instrumentos e técnicas em cada hospital onde atuam podem ser elementos explicativos - a serem mais bem explorados em análises e estudos posteriores - do maior desgaste referido entre eles.

Resumidamente, o perfil dos médicos que apresentam esse problema é o seguinte:

a) estão no início da vida profissional - com menos de dez anos de inserçăo no mercado de trabalho;

b) exercem quatro ou mais atividades;

c) são plantonistas, principalmente em setores de emergência e pronto-socorro em hospitais públicos, e médicos de serviços de apoio terapêutico-diagnóstico no setor privado;

d) sāo especialistas em doenças crônico-degenerativas; 
e) são cirurgiōes;

f) obstetras em rotina de maternidade;

g) médicos-residentes em áreas cirúrgicas;

h) trabalham em município diferente daquele em que residem;

i) têm rendimentos baixos, entre mil e dois mil dólares;

j) atuam em condições precárias, que os obrigam a fazer a medicina do 'possível'. 


\section{OS MÉDICOS E A PARTICIPAÇÃO NA VIDA POLITICO-SINDICAL}

\section{OS MÉDICOS E A NOVA ORDEM POLITICO-SINDICAL}

Durante a década de 70, a força de trabalho, segundo Offe, tornou-se mais sensivel e crítica à fadiga gerada pelo excesso de trabalho. No mundo inteiro, as reivindicaçōes por maior tempo para lazer e descanso cresceram mais do que aquelas por melhores condiçōes de trabalho. ${ }^{1}$ A redução gradual da jornada do trabalho é fruto da organização e da luta sindical travada não só pelos trabalhadores de linha (blue-collars), mas também pelos trabalhadores mais qualificados (white-collars). Com mais freqüência, assiste-se ao surgimento de movimentos grevistas desses segmentos profissionais mais qualificados, até então inimagináveis num contexto de luta sindical. Buscando conquistar melhores condiçōes de trabalho e melhores salários, ou mesmo garantir seus direitos trabalhistas, médicos, advogados, engenheiros e executivos de grandes empresas têm aderido aos sindicatos.

Estudos realizados por Oppenheimer (1975), Simóes (1992) e Mckinlay \& Arches (1986) analisam o fenômeno da sindicalização dos profissionais liberais e mostram que é um fato percebido em todas as sociedades atuais. $O$ fim ou a ameaça da perda de privilégios e prerrogativas monopolistas, bem como a crescente inserção no mercado de trabalho na condição de 'assalariados', têm levado parcelas significativas desses profissionais a buscar abrigo e proteção para seus direitos trabalhistas nos sindicatos. Simōes (1992:162-63) evidencia a questão da perda de status ocorrida nas profissōes liberais e mostra que:

A imagem predominante do profissional liberal tem sido confrontada com a realidade de um processo sócio-econômico em mudança que crescentemente transforma a grande maioria em assalariados e uns poucos em emprega-

1 Atualmente, a situação apresenta-se um pouco diferente: busca-se muito mais o equacionamento entre trabalho, lazer, descanso e ócio. 
dores. Se até duas ou três décadas atrás estes profissionais ainda eram vistos principalmente como 'profissionais liberais', nos últimos anos eles têm nitidamente se tornado trabalhadores assalariados, e algumas vezes têm combinado as duas posiçōes - de assalariamento e liberal. Simultaneamente a esse processo de transformaçōes estruturais e econômicas, também tem ocorrido uma mudança igualmente marcante na organização politica e de classe dos profissionais.

Desta forma, o processo de sindicalização dos chamados white-collars tem crescido em quase todo o mundo, até mesmo em maior proporção do que o dos tradicionais blue-collars. Oppenheimer (1975:35) analisa esta questão:

Enquanto a proporção da $\mathrm{FT}^{2}$ americana sindicalizada declinou aproximadamente $1 \%$ (de $23 \%$ para $22,6 \%$ ) entre 1960 e 1970 , a proporção de profissionais de colarinho-branco em todos os sindicatos americanos recebeu incremento de 12\%, em 1960, e de 16\%, em 1970.

No Brasil, o fenômeno da sindicalização entre os profissionais mais qualificados tem aumentado nas últimas décadas. Médicos, odontólogos, engenheiros, advogados, psicólogos, economistas, entre outros profissionais liberais, têm buscado se organizar em sindicatos. Os dados da pesquisa evidenciam que $44,9 \%$ dos médicos estão filiados ao sindicato médico. Os dados da Tabela 7.1 mostram o índice de sindicalização dos médicos nas Unidades da Federação e demonstram que tais índices são bem maiores em estados da região Nordeste, como, por exemplo, Alagoas $(76,5 \%)$, Ceará $(72,4 \%)$, Sergipe $(72,2 \%)$ e Rio Grande do Norte $(68,6 \%)$. Em contrapartida, as regiōes Sul e Sudeste apresentam índices muito mais baixos: São Paulo $(34,3 \%)$; Rio de Janeiro (39,9\%); Paraná (27,5\%); Santa Catarina (39,2\%).

Não dispomos de dados qualitativos que nos permitam explicar esta significativa diferenciação regional. Apesar disso, acreditamos que tal situação se deve à perda mais acentuada das condiçōes adequadas ao exercício profissional nestes estados, traduzidas em baixos salários - por vezes atrasados -, hospitais sem condições de atendimento e pequena oferta de empregos com salários condizentes, entre outras.

A perda do prestígio social tem levado os médicos a adotar movimentos em defesa da recuperação de seu status. Afirmam Mckinlay \& Arches (1986:55),

preocupados com problemas de 'auto-imagem', muitos médicos estão também optando por organizar-se sindicalmente (32,33\%). Existem hoje pelo menos 26 organizaçōes diferentes encarregadas da negociação coletiva em nome dos médicos. Em 1973, representantes de seis organizaçōes médicas formaram a Federaçăo Americana de Médicos e Dentistas e declararam mais de dez mil membros. Outras organizações, como a Federação Industrial de Profissionais Empregados (filiados ao AFL-CIO), vários gnupos ativos internos e residentes e muitos independentes, também têm grande número de membros. Um representante do Sindicato Nacional dos Médicos estima que o número de médicos filiados é mais ou menos trinta mil (em torno de $10 \%$ do total dos médicos); por outro

2 Força de Trabalho (Nota dos autores). 
lado, outro observador eleva a cifra para mais de cinqüenta mil. Recentes estudos e demonstraçōes públicas contra o aumento das taxas de seguro, contra má prática médica e conflitos sobre as horas de trabalho na Califórnia, Chicago e Nova lorque demonstram a vitalidade destes grupos.

Tabela 7.1 - Médicos sindicalizados segundo Unidades da Federação. Brasil - 1995

\begin{tabular}{|c|c|c|}
\hline $\begin{array}{c}\text { Brasil e } \\
\text { Grandes Regiōes }\end{array}$ & v. abs. & $(\%)$ \\
\hline REGIÁO NORTE & 3.304 & 58,0 \\
\hline Acre & 80 & 39,4 \\
\hline Amapá & 135 & 65,2 \\
\hline Amazonas & 792 & 59,3 \\
\hline Pará & 1.666 & 59,0 \\
\hline Rondônia & 300 & 59,8 \\
\hline Roraima & 55 & 38,2 \\
\hline Tocantins & 276 & 57,0 \\
\hline REGIÃO NORDESTE & 18.547 & 63,4 \\
\hline Alagoas & 1.747 & 76,5 \\
\hline Bahia & 5.567 & 63,8 \\
\hline Ceará & 2.672 & 72,4 \\
\hline Maranhão & 798 & 42,0 \\
\hline Paraíba & 1.910 & 64,4 \\
\hline Pernambuco & 3.264 & 57,0 \\
\hline Piauí & 556 & 52,9 \\
\hline Rio Grande do Norte & 1.171 & 68,6 \\
\hline Sergipe & 862 & 72,2 \\
\hline REGIÄO SUDESTE & 42.367 & 39,4 \\
\hline Espírito Santo & 2.113 & 60,5 \\
\hline Minas Gerais & 9.530 & 50,3 \\
\hline Rio de Janeiro & 10.769 & 39,9 \\
\hline São Paulo & 19.955 & 34,3 \\
\hline REGIẢO SUL & 10.833 & 38,5 \\
\hline$\overline{\text { Paraná }}$ & 2.430 & 27,5 \\
\hline Rio Grande do Sul & 6.646 & 44,9 \\
\hline Santa Catarina & 1.757 & 39,2 \\
\hline REGIÃO CENTRO-OESTE & 7.164 & 57,6 \\
\hline Distrito Federal & 3.083 & 64,4 \\
\hline Goiás & 2.218 & 51,0 \\
\hline Mato Grosso do Sul & 800 & 54,8 \\
\hline Mato Grosso & 1.063 & 57,8 \\
\hline BRASIL & 82.215 & 44,9 \\
\hline
\end{tabular}

Fonte: Pesquisa "Perfil dos Médicos no Brasil", Fiocruz/CFM. 
A Tabela 7.2 mostra os motivos que levaram os médicos brasileiros a filiar-se aos sindicatos. Os mais destacados são defesa dos interesses sindicais ( $49 \%$ ) e proteção do exercício profissional (32\%).

Tabela 7.2 - Motivos de sindicalização distribuídos por local de moradia. Brasil - 1995

\begin{tabular}{lrrrrrr}
\hline \multirow{2}{*}{ Motivos de sindicalização } & \multicolumn{2}{c}{ Capitais } & \multicolumn{2}{c}{ Interiores } & \multicolumn{2}{c}{ BRASIL } \\
\cline { 2 - 7 } & v. abs. & \multicolumn{1}{c}{ (\%) } & v. abs. & (\%) & v. abs. & (\%) \\
\hline Defesa dos interesses sindicais & 27.426 & 51,8 & 12.931 & 44,1 & 40.357 & 49,1 \\
Prestígio/status profissional & 43 & 0,1 & 34 & 0,1 & 77 & 0,1 \\
Proteção do exercício profissional & 15.921 & 30,1 & 10.559 & 36,1 & 26.480 & 32,2 \\
Outros & 7.700 & 14,5 & 5.140 & 17,6 & 12.840 & 15,6 \\
Ignorado & 1.835 & 3,5 & 626 & 2,1 & 2.461 & 3,0 \\
\hline TOTAL & 52.925 & 100,0 & 29.290 & 100,0 & 82.215 & 100,0 \\
\hline
\end{tabular}

Fonte: Pesquisa "Perfil dos Médicos no Brasil", Fiocruz/CFM.

\section{GREVE NA SAÚDE: UMA SAIDDA POLITICA?}

A discussão sobre a participação de médicos em movimentos sindicais e grevistas deve ser situada historicamente, a fim de possibilitar a compreensão não-maniqueísta do problema. A primeira organização dos médicos em sindicatos ocorreu no Rio de Janeiro, em 1927, no denominado Sindicato Médico Brasileiro, com sede na cidade do Rio de Janeiro. ${ }^{3}$ Essa associação tinha como objetivo principal a defesa do exercício profissional, combatendo os chamados 'charlatães do ofício'. A partir da década de 50, entretanto, os sindicatos voltaram-se especialmente para questões econômicas, refletindo o progressivo assalariamento da categoria.

Com o golpe militar de 64 e a intervençāo em suas principais entidades representativas, ${ }^{4}$ o movimento sindical perdeu vitalidade. Só em 1977 começaram a ser obsevvados os efeitos da reorganização desse movimento, com as primeiras manifestaçóes operárias na região do $\mathrm{ABC}$ paulista. Entre os médicos, os residentes são os que primeiro se manifestam, contemporaneamente às vitórias do Movimento de Renovação Médica (Reme) em alguns sindicatos. Suas vitórias iniciais em São Paulo e depois no Rio de Janeiro, na opinião de um dirigente sindical da época, propiciaram aos sindicatos "mobili-

3 Ressalte-se que os médicos foram o primeiro segmento de profissionais liberais a se organizar em sindicato.

4 Entre 1964 e 1965, foram efetuadas 433 intervençōes em sindicatos, federações e confederaçōes sindicais (CHORNY, GANEM \& VIANNA, 1980:15). 
zar os demais médicos, que entenderam a importância das lutas coletivas no sentido de novas conquistas" (Souza, 1982:3-4). Desses movimentos iniciais, calcados especialmente na participaçāo e mobilizaçăo dos médicos residentes, a categoria foi se organizando, até que, em 1981, é deflagrada importante greve nacional de médicos. Essa greve, de onganização nacional, foi um marco na atuação dos sindicatos médicos do País, em especial no Rio de Janeiro. ${ }^{5}$

A reorganização sindical dos profissionais liberais em geral e a dos médicos em particular, nos anos 80, é analisada por Vianna (1983:179):

o sindicalismo dos intelectuais (...) possui longas e sólidas raízes no processo de modernização capitalista, acelerado nessas últimas décadas (60 e 70), que, de um lado, produziu uma nova massa de intelectuais subordinados à lógica do capital $\mathrm{e}$ às relaçōes de assalariamento e, de outro, redefiniu o mercado de profissōes tradicionais, como a médica, a advocacia, a arquitetura, entre tantas.

Esses movimentos grevistas, no entanto, sofrem até hoje severas restrições ético-morais por parte da populaçăo e dos próprios médicos. Tal comportamento se justifica, em boa parte, pelo fato de o Código de Ética Médica proibir o não-atendimento. Segundo este código, em sua Resolução de $n^{\circledR} 1.246 / 88$ (p.16):

deve o médico ser solidário com os movimentos de defesa da dignidade profissional, seja por remuneração digna, seja por condiçōes de trabalho compatíveis com o exercício profissional da Medicina e seu aprimoramento ético. (Conselho Federal de Medicina, 1990)

Este mesmo código, em sua p.18 entretanto, afirma que é vetado ao médico

deixar de atender em setores de urgências e emergências, quando for sua obrigação fazê-lo, colocando em risco a vida dos pacientes, mesmo respaldado por decisão majoritária da categoria. (Conselho Federal de Medicina, 1990)

No Brasil, $65 \%$ dos médicos aderem à greve e defendem o atendimento apenas em casos de 'emergência'. Só $4,4 \%$ radicalizam, expressando a vontade de năo atender, qualquer que seja o caso, como exposto na Tabela 7.3. Para eles, de modo geral, a greve é uma forma extremada de conseguir melhores condiçōes de trabalho, melhores salários e preços adequados para os senviços que prestam.

Na sociedade brasileira, o médico é um profissional como outro qualquer, porém estigmatizado pelo sacerdócio pejorativo. Mesmo os sacerdotes recebem de suas igrejas boas condiçōes de moradia, alimentação, transporte, lazer (...) e só assim conseguem desempenhar seu 'trabalho', não menos digno e honrado que o exercício da medicina. Resguardados os casos de emergências, têm, sim, os médicos o direito de fazer greve! (ginecologista, masculino, 36 anos, PA)

5 No Rio de Janeiro, a prisão do presidente do sindicato dos médicos levou a uma manifestação ímpar de união e organização dos médicos. Nessa greve, eles contaram com a participação ativa e solidária de sindicatos de outras categorias e associaçóes de moradores de bairros e favelas (SOUzA, 1982). 
Tabela 7.3 - Médicos distribuídos por local de moradia segundo opiniáo sobre greve na saúde. Brasil - 1995

\begin{tabular}{lrrrrrr}
\hline \multirow{2}{*}{ Opiniäo sobre greve } & \multicolumn{2}{c}{ Capitais } & \multicolumn{2}{c}{ Interiores } & \multicolumn{2}{c}{ BRASIL } \\
\cline { 2 - 7 } & \multicolumn{1}{c}{ v. abs. } & $(\%)$ & v. abs. & (\%) & \multicolumn{1}{c}{ v. abs. } & \multicolumn{1}{c}{$(\%)$} \\
\hline Atender normalmente & 21.574 & 17,9 & 8.569 & 13,7 & 30.143 & 16,6 \\
Atender casos de emergência & 74.040 & 61,4 & 44.896 & 72,0 & 118.936 & 65,0 \\
Năo atender & 5.371 & 4,5 & 2.639 & 4,2 & 8.010 & 4,4 \\
Outras & 13.122 & 10,9 & 3.755 & 6,0 & 16.877 & 9,2 \\
lgnorada & 6.555 & 5,4 & 2.531 & 4,1 & 9.086 & 5,0 \\
\hline TOTAL & 120.662 & 100,0 & 62.390 & 100,0 & 183.052 & 100,0 \\
\hline
\end{tabular}

Fonte: Pesquisa "Perfil dos Médicos no Brasil", Fiocruz/CFM.

A desvalorização do ato médico tem sido tăo fortemente percebida, que uma das questões mais relevantes passa a ser uma 'justa remuneração':

Os médicos estão se dando conta de que precisam de dinheiro para sobreviver. Costam do que fazem, mas ser remunerado por isso não é pecado. Vamos acabar com essa história de sacerdócio, isso é para padres (...). A dignidade médica, boas condiçóes de trabalho, salários justos têm de ser uma reivindicação permanente. (cirurgiāo cardiovascular, feminino, 31 anos, PE)

Nāo vejo outra forma de luta a nāo ser a greve. Se existisse uma autoridade consciente, e o médico recebesse um salário digno, não haveria necessidade dessa prostituição a que se sujeitam muitos, trabalhando em condiçōes precárias, dando plantões e mais plantöes em estabelecimentos vergonhosos para receber míseros tostōes, estando sujeitos à caça às bruxas, arriscando-se a arcar com um processo por erro médico, quando muitas vezes não se trata de falta de capacidade do profissional, mas, sim, de falta de recursos para que possa trabalhar com dignidade. (pediatra, feminino, 26 anos, SP)

Para ganhar de três a quatro mil reais, o médico é obrigado a atuar em vários locais com uma medicina de baixo nível, pobre em tudo (exames e paramédicos), com carga horária altíssima. (anestesiologista, masculino, 37 anos, PR)

Embora os médicos considerem a greve uma medida radical, a realidade não Ihes dá alternativa:

Infelizmente, o movimento grevista mostra-se como uma pesada e exaustiva forma de luta pelos direitos do médico, enquanto profissional e cidadão. Embora longe de ser a ideal, é necessária em alguns momentos, uma vez que se torna a única chance de chegar a uma situação digna no trabalho, após esgotadas todos as formas de negociaçāo. (médico do trabaIho, feminino, 29, ES) 
A pequena adesão dos médicos aos movimentos grevistas é em parte explicada pelo fato de que esses profissionais, na maioria das vezes, têm múltiplos vínculos no mercado de trabalho, ora como assalariados, ora como profissionais liberais (em seu consultório), ora como autônomos (trabalhando numa instituição sem vínculo empregatício), ora como subempregados (às vezes do próprio colega médico). Esta multiplicidade de inserções no mercado de trabalho os torna, muitas vezes, incapazes de perceber sua real condição na estrutura ocupacional, o que explica em boa parte sua pequena adesão política.

Acho os médicos fracos pela sua desunião, não formamos uma classe. Aliás, há médicos que não se consideram trabalhadores. Daí, se não temos os mesmos objetivos, como poderemos participar ativamente de greves ou de outro tipo de luta pela defesa profissional? (intensivista, feminino, 31 anos, PB)

A participação é mínima, já que a maioria detém vários empregos e sempre os considera isoladamente como 'bicos' e, portanto, não luta com vigor para melhorá-los. (cardiologista, masculino, 31 anos, PR)

O resultado acaba sendo um diagnóstico negativo, pessoal, que leva à autopunição pelo fracasso das greves:

As greves de saúde não atingem seu objetivo, já que se trata de uma categoria profissional heterogênea, com vários interesses dissociados. Não se pode esperar adesāo à greve de um médico que tenha sua clínica particular bem-sucedida para apoiar os colegas que trabalham na rede pública de saúde. Não há consciência de classe. (gastroenterologista, feminino, 36 anos, RJ)

Para outros médicos, a imagem social da greve está desgastada em função da propaganda negativa da mídia. As notícias veiculadas na imprensa enfatizam os constrangimentos que esses movimentos de paralisação do atendimento médico causam à população. Logicamente, por estar o médico à frente do atendimento e ser o personagem central na assistência, ele acaba recebendo o maior peso das críticas.

Por ser um serviço essencial, as autoridades politicas e a mídia se encarregam de jogar a população contra os médicos, como se fôssemos responsáveis pelos descalabros da saúde no País. (anestesiologista, masculino, 43 anos, RS)

O médico é visto pela comunidade como mercenário, a comunidade acha que temos só deveres, temos que ser como máquinas, operar milagres mesmo com péssimas condiçōes de trabalho. Por que não são mostradas as condiçōes de trabalho do médico no sertāo ou de um pequeno estado nordestino? (ginecologista, feminino, 30 anos, PB)

Em muitos casos, a população não entende as razōes da greve e se manifesta contrária a ela. 
As greves costumam ser ineficazes, pois nem os nossos familiares conseguem entender o não-atendimento de uma pessoa doente, mesmo que seja para melhorar as condiçōes para esse mesmo paciente. A população sempre se posiciona contra. Nossas greves não trazem prejuizos financeiros ao País, logo não temos força. (pediatra, feminino, 29 anos, MS)

\section{UMA NOVA POSTURA POLITICA: RECUPERANDO O 'STATUS QUO'}

Mesmo considerando que a maioria dos médicos é favorável às greves, isto não significa que eles não adotem outras formas de luta política para obter ganhos e recuperar sua imagem e seu papel no cenário político-social do País (Tabela 7.4).

Recuperar a imagem do médico, sem dúvida, é a maior preocupação da corporação. Para os médicos, a imprensa tem dedicado tempo excessivo, nos jornais, revistas e televisão, aos acontecimentos negativos que colocam esse profissional no centro das atençōes, deixando-o quase sempre em situaçōes de desconforto e, por vezes, imputando a ele a responsabilidade pelo ocorrido. A imagem de caos no sistema de saúde associada ao médico é freqüentemente veiculada pela mídia. Assim, recuperar a 'boa imagem' torna-se crucial:

$\dot{E}$ comum e fato extremamente corriqueiro os pacientes se voltarem contra os médicos de uma instituição quando não conseguem realizar os exames solicitados, comprar ou buscar nos postos de saúde a medicação prescrita, etc. A população deve ser alertada de que a culpa não cabe aos médicos e, sim, às instituiçōes responsáveis pelo aparelhamento e às condiçōes técnicas e sociais sob as quais o profissional exerce a atividade. A escolha de salvar a vida de um ou de outro paciente é extremamente sofrida por parte do médico. Faz-se necessária maior denúncia das condiçōes de trabalho, desde o repouso médico até as condiçōes físicas do local de trabalho. (médico do trabalho, feminino, 28 anos, GO)

É necessário criar mecanismos que propiciassem ampla informação à sociedade, para que o médico nāo seja considerado 'culpado' pelas desfavoráveis condiçōes de atendimento em instituiçōes públicas. (dermatologista, feminino, 37 anos, AL) 
Tabela 7.4 - Principais formas de luta sugeridas.* Brasil - 1995

\begin{tabular}{lcc}
\hline \multicolumn{1}{c}{ Formas de luta } & v. abs. & (\%) \\
\hline Recuperaṛ a imagem do médico & 69.312 & 31,5 \\
Lobby no Congresso Nacional & 32.828 & 14,9 \\
Fortalecimento das entidades corporativas & 27.960 & 12,7 \\
União dos médicos & 23.785 & 10,8 \\
Demissão coletiva do serviço público & 16.320 & 7,4 \\
Melhoria da formação médica & 9.498 & 4,3 \\
Greve como única alternativa & 8.265 & 3,8 \\
Autovalorização profissional & 6.740 & 3,1 \\
Descredenciamento dos convênios/cooperativas & 6.098 & 2,8 \\
Negociação coletiva & 5.743 & 2,6 \\
Comissöes de avaliação do sistema de saúde & 3.778 & 1,7 \\
Greve branca** & 3.309 & 1,5 \\
União com outros profissionais da saúde & 2.422 & 1,1 \\
Criação de cooperativas médicas & 2.385 & 1,1 \\
Exigência de staff gerencial qualificado & 1.517 & 0,7 \\
\hline TOTAL & 219.960 & 100,0 \\
\hline
\end{tabular}

* Cada médico poderia citar até três formas de luta.

** Na categoria 'greve branca' foram induídas as sugestóes dos médicos de interrupção da concessão dos atestados médicos; do fornecimento de atestados de b́bitos, da liberaçăo de laudos, exames etc. As propostas de não entregar AlH e outras formas de remuneração ao Estado, bem como de atender os pacientes normalmente nos locais de trabalho, porém sonegando as informaçōes necessárias, atendendo sem préencher produção, também estão aí incorporadas.

Fonte: Pesquisa "Perfil dos Médicos no Brasil", Fiocruz/CFM.

Para desfazer essa imagem negativa junto à opiniāo pública, os médicos sugerem fazer campanhas na mídia:

Usar o serviço de telecomunicações para elevar o valor social do médico e não apenas denegrir a imagem do médico. Desta forma, talvez conseguíssemos o apoio da comunidade leiga aos nossos pleitos. (intensivista, feminino, 29 anos, $\mathrm{AL}$ )

Mobilizar a populaçāo através da imprensa, mostrar a realidade médica e as condições precárias de trabalho nos postos de saúde estatais, ambulatórios, etc. Mostrar a verdadeira produçāo em série, exigida dos colegas pelas empresas de grupo, nos atendimentos ambulatoriais, restringindo o número de exames e indicaçōes de cirurgias, e as altas precoces, etc. Mostrar à população que o médico não é o vilão da história. (intensivista, masculino, 56 anos, SP) 
Que cada médico lute para se auto-afirmar perante a sociedade em que vive, como o ser que estudou e estuda durante anos o corpo humano e por isso merece mais dignidade e respeito da populaçāo. A auto-afirmação vai se basear na seriedade do tratamento de cada doente, em diagnosticar da forma mais correta, em ser técnico no que faz. Com estes preceitos, o médico impera, se impōe e é respeitado como profissional competente. (pediatra, feminino, 36 anos, SP)

É necessário desfazer o senso comum de que os médicos constituem uma casta de privilegiados, transformada em verdadeira 'máfia de branco', como relata este médico:

Conscientizar a população de que não somos a máfia de branco, que os outros caracterizaram em outras épocas, através da propaganda sobre nossa importância na sociedade. Mostrar às pessoas que também precisamos de bons salários para termos outras preocupaçōes, como estudar medicina, para melhorar nossos atendimentos. (intensivista, feminino, 31 anos, PB)

Se, por um lado, os médicos buscam desconstruir sua imagem de "máfia de branco", por outro, adotam uma nova postura política, declarando-se favoráveis à constituição de um lobby político organizado nas instâncias do poder legislativo. Desta forma, chegam até a propor a eleição de médicos para cargos políticos, a fim de defender seus interesses corporativistas, formando, assim, o lobby na saúde, sugerindo:

... ter parlamentares médicos nas câmaras legislativas e no Congresso Nacional, para viabilizar o atendimento das reivindicações da categoria. (médico do trabalho, masculino, 38 anos, DF)

... a criaçāo de um bloco parlamentar no Congresso, ligado a nossa atividade, assim como outras atividades (tipo bancada ruralista). (cirurgião-geral, masculino, 42 anos, SP)

... pressão política sobre os congressistas, participação real na politica. Lutar por leis que melhorem a assistência à saúde. Lobby por leis que fiscalizem as empresas privadas de saúde e obriguem ao menor lucro e maior repasse de honorários aos médicos e melhor prestação de serviços aos usuários. (ginecologista, masculino, 47 anos, DF)

Até mesmo a criação de um partido próprio é almejada por alguns médicos que propöem:

... a criação do 'Partido Branco'. Formação de bancadas médicas na Câmara, voltadas à classe médica e não ao partido. Pressão sobre o Congresso. (ginecologista, feminino, 38 anos, $\mathrm{AL}$ )

A necessidade de uma atuação mais efetiva das entidades médicas (sindicatos, conselhos e associaçōes) é outra forma de luta apontada pelos médicos. Como mediadoras entre os médicos e o Estado, e constituindo as principais interlocutoras da expressão dos profissionais, as entidades médicas cumpririam, na verdade, a fun- 
ção de formular, controlar e mediar as negociaçōes entre as partes. Assim, os médicos sugerem:

Maior fiscalização das ações dos governos referentes à saúde por nossas entidades de classe, cobrando repasse de verbas, aplicação efetiva de recursos destinados à saúde, implantação de programas, etc., para que não continuemos somente remediando, mas possamos atacar as causas dos problemas. (patologista, feminino, 45 anos, DF)

As entidades de classe agindo junto às autoridades competentes, no sentido de defender salários dignos e condiçōes de trabalho que correspondessem às exigências mínimas para o exercício da profissão, evitando, assim, que o profissional da saúde se desvalorize prestando serviços em condições precárias $\mathbf{e}$ aviltantes quanto a seus honorários, servindo aos proprietários de convênios, que lucram abusivamente usando o médico como seu instrumento. (ginecoobstetra, masculino, 62 anos, RJ)

Maior participaçăo política através das associações médicas (sindicatos $\mathrm{e}$ conselhos) para tomar as decisōes governamentais cabiveis para melhoria no setor saúde, não só do ponto de vista salarial, mas das condiçōes atuais em que trabalhamos. (cirurgião cardiovascular, feminino, 28 anos, SP)

Contínuas denúncias de todos os órgãos de classe sobre o vasto sistema de corrupção existente na saúde. Pressōes sobre os representantes da classe médica no poder legislativo, para que denuncie em público esse vasto esquema de corrupção, punição pelos conselhos de medicina de "colegas" comprometidos com esse esquema de corrupção. (cirurgiáo-geral, masculino, 50 anos, SP)

Ter um papel fiscalizador, de intermediador dos interesses da corporação, é uma das reivindicações mais importantes. Essa intermediação política sugere a presença constante das entidades médicas nos locais de trabalho, fiscalizando e assegurando o bom exercício profissional, daí ser essencial:

A presença freqüente das entidades representativas da classe nos hospitais públicos. Tornar pública a situação específica de cada unidade de atendimento. (cirurgião-geral, masculino, 46 anos, SP)

Que as entidades médicas responsáveis, efetivamente, fiscalizassem as condiç̄os de trabalho e respaldassem o fechamento das unidades sem condiçōes ideais. Jogar todo'o peso na classe médica e suas entidades representativas na efetiva melhoria salarial, pois um salário compativel com a responsabilidade da profissão é um passo importante para a recuperaçăo da dignidade profissional. (pediatra, masculino, 39 anos, R))

As entidades médicas devem fiscalizar e intervir também na esfera privada, em função da relação excessivamente comercial que acaba se estabelecendo com aquele que intermedia a compra e venda dos serviços médicos. Nesta situação, a proposta é: 
Abolir atendimentos por meio de medicina de grupo como subempregos. Dever-se-ia obedecer, no mínimo, aos valores estipulados previamente. $O$ CFM e a $A M B$ precisam intervir nos serviços de medicina de grupo e cooperativas. (médico do trabalho, masculino, 36 anos, MG)

Pressionar de forma maciça e coletiva as empresas de prestação de serviços, inclusive as Unimeds, para a melhoria da remuneração dos convênios. São um absurdo total as Unimeds, que, na conversa, são dos médicos, mas fazem a mesma prática de remuneração vil das empresas mercantilistas. Que corporativismo é esse? (oftalmologista, masculino, 36 anos, GO).

Insatisfeitos com os valores pagos pelos convênios aos serviços médicos, esses profissionais sugerem o descredenciamento dos convênios como forma de pressionar para obter uma negociação melhor.

Descredenciamento de todos os convênios. Fixação dos nossos próprios honorários, ou seja, fixação unilateral do $\mathrm{CH}^{6}{ }^{6}$ sem consulta a convênio ou cooperativa, sendo, portanto, essenciais a autonomia, o descredenciamento unilateral. Não podemos mais depender das normas e disponibilidade dos convênios, devemos responder unicamente aos conselhos regionais e especialidades. (ginecologista, masculino, 43 anos, SP)

Deveria ser suspenso o atendimento de determinado convênio por toda a classe médica até que ele concorde em pagar o $\mathrm{CH}$ da $A M B$ na tabela de 1992. Seria um movimento regionalizado, porém de âmbito nacional. Cada convênio que não se adequasse teria suspenso o atendimento (...). Seriam atendidos apenas os casos de emergência, pelo SUS e năo pelo convênio, durante o período de paralisação. (intensivista, masculino, 35 anos, MG)

A conscientizaçāo e união entre os médicos é outra forma adotada por eles. Assim, a mudança interna de comportamento político seria fundamental para buscar uma efetiva mudança na situação vigente:

Acredito que se nós, médicos, tomássemos consciência do nosso papel como classe, estariamos sempre unidos e, desta forma, venceríamos, sem dúvida, todos esses imensos problemas, esse grande descaso. (clínico geral, feminino, 30 anos, $\mathrm{Al}$ )

A classe médica é a classe mais desunida que já conheci. É cobra engolindo cobra. Se os objetivos são os mesmos, por que não lutar pela melhoria da classe? Se estou num ambiente público e vejo o errado, é mintia obrigação dizer a verdade, a maioria se omite e a coisa vai piorando cada dia mais. Quem cala consente. (oftalmologista, feminino, 46 anos, BA)

Melhorar a formação profissional constitui outra preocupação dos médicos. Fechar escolas desqualificadas, impedir a abertura de novas escolas, submeter os médicos a exames periódicos de qualificação tornam-se opções concretas

6 A expressão Coeficiente de Honorários $(\mathrm{CH})$ nasceu, praticamente, com a tabela da AMB, edição 1984. Veio substituir o que se conhecia como Unidade de Serviços (US), oriunda do antigo INPS. 
para alterar o atual quadro negativo. Segundo a opinião de alguns médicos, a maioria das escolas criadas no contexto do boom das décadas de 60 e 70 têm pouca preocupação com a qualidade da formação de seus alunos. Estes profissionais, mal formados, acabam denegrindo a imagem da profissão perante a sociedade. Sugerem, então:

Restaurar a dignidade, não permitindo a criação a granel de escolas que não selecionam nem moral, nem intelectualmente os profissionais que abarrotam o mercado, cada vez mais inchando os senviços, aumentando a concorrência desleal, tendo que recorrer sempre às greves para a sobrevivência. (medicina interna, masculino, 54 anos, SP).

A melhoria da qualificação médica depende da diminuiçăo do número de faculdades e da melhoria das qualificadas (que são muitas), todas elas em hospitais qualificados para o exercício dos alunos. Exigir residência nas especialidades para o exercício profissional no Brasil. Escolas sem condição alguma formam médicos teoricos, que nunca viram ou examinaram um doente, que recebem o diploma e são credenciados pelas Unimeds do Brasil. (cirurgiăo-geral, masculino, 57 anos, SP)

Diminuir a relação entre oferta e demanda é uma das saídas sugeridas por alguns médicos:

Reduzir dramaticamente o número de vagas nas faculdades para formar exclusivamente o número de médicos necessários ao País. Isso daria condições para melhorar a formạa̧ão médica e aumentar o poder de negociaçăo de classe. (patologista, masculino, 60 anos, SP)

Fechar 50\% das faculdades de medicina hoje existentes no Brasil. (gineco-obstetra, masculino, 46 anos, TO).

Numa situação-limite, na qual o profissional se vê desprestigiado não apenas pelas péssimas condições de trabalho, mas também pelos baixos salários, a demissão coletiva passa a ser uma alternativa política:

Demissão de todo o corpo clínico quando estiver presente a falta de condiçōes de trabalho, quer seja salariais ou de atender igualmente a população. (gineco-obstetra, feminino, 42 anos, SP)

Além disso, os médicos sugerem que as entidades responsáveis pela fiscalização profissional (CRMs) interfiram, impedindo que médicos sem condiçōes adequadas de trabalho exerçam a profissão:

Suspensāo, pelo CRM, do médico que exercesse a profissão em locais sem remuneração justa estipulada pelo Conselho e/ou sem condiçöes técnicas para o trabalho. (cardiologista, masculino, 27 anos, SP)

Não aceitar salários irrisórios e tentar mostrar aos colegas o porquê: se recebo um salário vil, tento compensar trabalhando em outros locais que possam me suprir do que não recebi. Conheço colegas que acumulam cinco empregos públicos em estados diferentes para poder ter uma vida digna, mas no fi- 
nal de semana estão uns mortos-vivos e ainda complementam com atendimento no consultório. (oftalmologista, feminino, 46 anos, BA)

Operação padrāo, seguindo as recomendaçōes da OMS quanto às condiçöes no atendimento de cada paciente, número de pacientes por hora, exames clínico, ffsico e laboratorial, local de atendimento, repouso do médico, etc., inclusive com apoio dos conselhos, que se omitem na hora de fazer cumprir o código de ética médica. (cirurgiāo-geral, masculino, 43 anos, CE)

Radicalizando a fim de que suas reivindicações sejam atendidas, alguns propõem até medidas drásticas, como:

Matar um médico a cada dia no Congresso até que todas as reivindicaçöes sejam atendidas. (gineco-obstetra, masculino, 46 anos, TO) 


\section{CONCLUSÕES}

\section{CONSTRUINDO POLITICAS DE RECURSOS HUMANOS}

Ao longo deste livro buscamos mostrar o retrato da realidade dos médicos que atuam no Brasil. Sendo fiéis às evidências empíricas, mostramos que esses profissionais 'encontram-se na UTI': na UTI das instituiçōes públicas; na UTI das instituições privadas; na UTI de seus consultórios. Os salários, as condiçōes de trabalho, a insatisfaçăo, o desgaste, o estresse, o desestímulo e a desesperança tomam conta da vida diária dos médicos brasileiros.

No entanto, adotando a premissa nietzchiana, de que do caos é possivel emergir uma nova ordem, a pesquisa permitiu identificar alguns problemas de extrema importância para a formulação de políticas de recursos humanos adequadas às necessidades da população, bem como aos interesses $e$ às necessidades profissionais dos médicos. Várias são as questōes que suscitariam uma reformulação profunda nessas políticas, visando efetivamente compreender e intervir positivamente no complexo e sofisticado quadro de recursos humanos: questões de formação profissional, de mercado de trabalho, demográficas, político-sindicais etc.

No primeiro capítulo, ao analisar os dados demográficos, percebemos alguns fenômenos recentes ocorridos no contingente médico, o que nos levou a afirmar que a profissão médica brasileira experimenta 'processos de transição' que transformarão sua estrutura sócio-demográfica e, certamente, a mentalidade de seus participantes. Um primeiro processo é o da 'transição sócio-cultural', qual seja, os médicos de hoje são, em sua maioria, filhos de classe média urbana, de profissionais liberais urbanos. Estes médicos, acostumados a viver e a desfrutar dos equipamentos sociais e culturais característicos e disponíveis nos grandes centros, dificilmente abandonariam esta estrutura para se fixar em algum local no interior do País. Desta forma, a crescente urbanizaçăo destes profissionais é particularmente fruto de sua origem, 
aliada à ausência de políticas adequadas que promovam o convencimento suficiente para que se busque fazer medicina fora do circuito 'comercial'.

Está claro que não basta a oferta de empregos com salários mais elevados para que o médico jovem opte pelo interior. Várias têm sido, ao longo destes anos, as medidas governamentais nesse sentido, ainda que quase todas infrutíferas. Para vislumbrar mudanças neste novo quadro só mesmo com a adoção de políticas específicas que transformassem os 'interiores' em meios sociais dotados de recursos técnicos e científicos capazes de estimular os médicos ao exercício da profissão fora do circuito comercial.

Não podemos negar que, cada vez com mais intensidade, os médicos não conseguem fazer medicina sem uma constante e rigorosa reciclagem técnico-científica. A velocidade da produção de novos conhecimentos nas ciências médicas tem impedido tecnicamente que o 'fazer cotidiano' assuma lugar preponderante, exigindo, assim, que o 'saber renovado' faça parte também deste dia-a-dia médico. A mentalidade dos usuários também mudou e tem exigido do médico um rigoroso e atualizado conhecimento de novas técnicas, novos medicamentos, novas habilidades, ou seja, desafios constantes thes săo apresentados diariamente. No entanto, a pesquisa mostra claras evidências de que os médicos se queixam de abandono das autoridades, sejam elas governamentais ou corporativas, quanto à sua reciclagem profissional após completar o ciclo de formação.

Diante desse quadro, como conciliar tantos interesses e questões relevantes? Para isto, consideramos necessário adotar programas especiais de incentivos financeiros - salários diferenciados e com estímulos específicos para cada região - e de incentivos técnico-científicos - educação-continuada com prévia programação de cursos; seminários específicos à área de atuação; fomento à participaçăo em eventos científicos realizados nos grandes centros de produção de conhecimento do País; criação de centros de estudos nas instituiçōes de saúde (de médio e de grande porte) acompanhada de dotação de recursos técnico-financeiros (biblioteca com revistas médicas científicas - nacionais e internacionais - vídeo e equipamento computacional (Internet)), para que nestes locais os médicos pudessem fazer 'reciclagem profissional'.

Um segundo processo é o de 'transição demográfica'. Estamos nos referindo a um crescente e dominante contingente de jovens e de mulheres na profissão, o que significa afirmar que o ofício está em processo de rejuvenescimento, fruto dos anos 70 e 80 e que certamente continuará com intensidade nas próximas décadas. No entanto, não se pode negligenciar o aspecto geracional deste fenômeno, ou seja, hoje a profissão médica no Brasil ostenta a cifra de mais de 120 mil profissionais com idade entre 30 e 50 anos, o que quer dizer que quase $70 \%$ de seu contingente, na segunda década do ano 2000, estará se aproximando da geração dos idosos.

$\mathrm{Em}$ decorrência desse fato as autoridades governamentais precisam adotar políticas específicas para a cooptaçăo deste 'contingente rejuvenescido', disponível e produtivamente importante para o sistema de saúde, seja ele de natureza pública 
ou privada. A 'antipolítica' recorrente adotada pelos compradores de serviços (não importando se privados ou públicos) - a de que médico é igual a 'sal' (branco, abundante e barato) - é no mínimo desprezível e revela como há muito tempo a saúde neste País deixou de ser, para o Estado, um bem essencial. O Brasil precisa de médicos nos lugares certos. Os interiores deste País, constituídos por mais de 4.500 municípios, necessitam de assistência médica. É necessário adotar políticas de oferta de empregos e de incentivos de produção de serviços, quer esteja o profissional vinculado ao setor público, privado ou em seu consultório. O momento político de municipalização é propício a essas medidas concretas de ajustes entre as necessidades da população e os interesses dos médicos.

Em segundo lugar, as autoridades precisam voltar a atenção para a formulação de políticas específicas e compensatórias para este enorme contingente de mais de 120 mil médicos que terá entre 50 e 70 anos em 2020 e que, certamente, estará buscando formas alternativas de exercer a profissão no início do século XXI. A pesquisa mostrou que os médicos, após vinte e cinco anos de trabalho, tendem a regressar aos grandes centros. Dotados de grande experiência e conhecimento, adquiridos ao longo da carreira, tendem igualmente a reduzir a jornada de trabalho, associando quase sempre a atividade de consultório a uma assalariada. É prudente, neste sentido, pensar também em políticas de desenvolvimento de recursos humanos específicas para este especial contingente da categoria.

A 'feminilização', como se assinalou, constitui o outro aspecto da transição demográfica. Este processo nos faz pensar em uma nova estrutura tanto das organizações que abrigam esses profissionais como na estrutura da produção desses mesmos serviços. Constatamos também que as médicas brasileiras, embora apresentem rendimentos inferiores a de seus colegas, trabalham muito e se desgastam bastante, tanto quanto os médicos.

A escolha da especialidade e do local onde exercerão a medicina definirá o tipo de inserção sócio-econômica. Nos depoimentos extraídos da pesquisa, pôde-se constatar que elas acabam por fazer 'escolhas forçadas' por terem que conciliar o mundo da vida privada com o mundo da vida pública. Isto ocorre também por imposição da forma 'masculina' em que está estruturada a produção da maioria dos serviços médicos. É bom lembrar que quase todas as estruturas do processo produtivo foram montadas e definidas para indivíduos (quase sempre homens) 'sem família', ou seja, para aqueles que não necessitam 'perder' parte de seu tempo produtivo em questões familiares, tais como procriação, aleitamento, educação de fithos, problemas de doença, entre tantas outras. O mundo médico é um caso exemplar dessa dicotomia entre o mundo da vida privada e o mundo da vida pública. Ser médico significa, de certo modo, adotar o modelo de trabalho sacerdotal, pelo fato de constituir uma das poucas atividades humanas que exigem pronto e obrigatório atendimento ao indivíduo necessitado de cuidados. 
Médico não pode ter filhos, casa etc. É uma profissão 'castrante', principalmente no interior, onde sāo 24 horas no ar. Sua vida se torna pública. Todos sabem onde você está. Se você atende urgência, piorou. (oftalmologista, feminino, 46 anos, BA)

Se, para o médico, é difícil cumprir tais preceitos éticos da profissão, pode-se imaginar como será oneroso para as médicas levar a cabo essa mesma tarefa.

Acho que, quando se escolhe a especialidade, o sexo não tem nada a ver, é uma preferência pessoal, ambos têm as mesmas condiçōes de se dedicar. Mas, para o sexo feminino torna-se mais estressante pelo fato de se ter que administrar o trabalho doméstico, filhos, consultório elou hospital, marido, lazer quando é possivel (isto é tão raro que nem conta!). Normalmente os fithos começam a cobrar sua assistência (...). Vou fazer vinte anos de formada e nảo tenho ainda minha casa própria, nunca tive carro e não tenho consultório próprio. Férias, nunca tive. Nāo sou desonesta. Medicina é liberal só no nome porque na realidade é uma escravidão, sem recompensas de qualquer espécie.

A mulher casada que tem filhos e uma profissão é uma 'heroína'. Para ela deveria haver uma estátua em cada praça deste país. As mulheres que, além de filhos, marido e da casa, ainda têm uma profissāo fora, precisando arcar com uma jornada absurda de trabalho, provam que ainda falta muita luta para que os direitos dos homens e das mulheres sejam reconhecidamente iguais! Se é que algum dia isso vai acontecer. (oftalmologista, feminino, 46 anos, BA)

No capítulo 2 mostramos a situaçāo dos profissionais e a necessidade de uma formação cada vez mais especializada, marcada também fortemente pela exigência de profissionalização após o término do curso de medicina. Os resultados da pesquisa apontam para a importância de discutir alguns pontos que consideramos cruciais para a formulação de políticas de formação e desenvolvimento de recursos humanos.

Em primeiro lugar, mais do que as escolas privadas (localizadas em boa parte nos interiores desenvolvidos), as escolas públicas, quase todas nos grandes centros urbanos (capitais), promovem um movimento de concentração de seus egressos ao redor de si mesmas. Ou seja, proporcionalmente, sāo poucos os médicos oriundos dessas escolas que saem desse circuito científico e, assim, conseguem inserir-se no circuito comercial das capitais. A excelência acadêmica, os programas de formação de pós-graduação, as inovações tecnológicas, entre outras características, em grande parte presentes nas escolas públicas, sāo provavelmente responsáveis por essa incontrolável vocação concentradora. Em recente trabalho, Guimarăes (1997:8) mostra que

em todos os países com alguma tradiçāo de C\&T, há algum grau de concentração geográfica na atividade de pesquisa. Nos EUA, tomando como indicador a produção de doutores, esta concentração é claramente observada. Apenas cerca de $10 \%$ das instituiçōes de ensino superior do país os formaram em 1993. Dentre essas, um número muito significativo situa-se na Califórnia e no nordeste 
do país. No entanto, no Brasil, tudo indica que esta concentração esteja atingindo um grau excessivo. Em 1992, a USP sozinha foi responsável pela formação de $36,3 \%$ dos cerca de 2.500 PhDs produzidos no país (CRUB, 1992). Se agregarmos as três outras universidades públicas localizadas no estado, a proporção atinge $60 \%$.

Em segundo lugar, o processo de especialização que experimenta a medicina tem levado os recém-formados a fazerem escolhas mais racionais e menos vocacionais, amparados na idéia de fazer medicina mais tecnológica, com menos envolvimento pessoal e que lhes dê maiores rendimentos. A escolha profissional tem recaído em áreas mais 'tecnificadas', tais como especialidades cirúrgicas e a de imagens e diagnósticos, todas altamente sofisticadas e, preferencialmente, desenvolvidas em grandes centros.

O quadro que apresentamos no capítulo 4, com algumas 'subespecialidades' existentes no mercado, elucida bem o que acabamos de mostrar. Além dessas, sabe-se da existência de médicos especializados em diagnósticos raros, como, por exemplo, em cefaléia, em distúrbios do sono, enfim, em uma infinidade de subespecialidades que se dirigem a uma seleta clientela, criando mercados de serviços com forte monopólio. Observamos também o processo de esvaziamento e/ou desaparecimento de algumas especialidades, tais como: broncoesofagologia, pneumologia, eletroencefalografia, medicina sanitária, fisiatria, patologia e patologia clínica, entre outras. Da mesma forma, notamos a existência de especialidades de baixa demanda, quase inexistentes no mercado de serviços médicos: nutrologia, foniatria, sexologia, a própria fisiatria etc.

O que estamos mostrando, na verdade, é a necessidade de repensar o quadro de especialidades que ora se apresenta. Chama-nos a atenção o fato de que este mercado tão bem esquadrinhado e segmentado não tenha quase ou nenhum mecanismo regulatório de oferta e demanda. Ou seja, não há, a rigor, nenhum órgão ou entidade que estabeleça regras e normas formais regulando a atuação do médico como cirurgião vascular, ortopedista, psiquiatra ou mesmo especialista em cefaléia, distúrbios do sono, ultra-sonografia vascular etc. Mesmo sabendo do esforço das entidades médicas em buscar um controle da prática médica especializada, a regulação acaba sendo realizada, em parte, pelas 'sociedades de especialistas', por meio de critérios muito mais ético-morais do que efetivamente por uma avaliação do conhecimento que aquele profissional possui.

O mercado de serviços médicos especializados é, como afirmamos, desregulado. Sua regulação se dá menos no aspecto formal e muito mais no domínio da ética e da moral profissional, isto é, com a atuaçăo da comunidade de pares que controla comportamentos e atitudes desviantes e nocivos à corporação. Desta forma, aquele que não adquiriu uma formação adequada para exercer uma determinada especialidade se sentirá retraído a exercê-la. Este é um dos temas-chave da agenda da área de formação médica: a regulação da formação médica especializada para o mercado (cursos de especialização e residência médica). 


\section{O médico no contexto do SUS}

A implementação do Sistema Único de Saúde (SUS) constitui um marco na evolução do sistema de saúde brasileiro. Sua concepção segue a tendência de universalização da cobertura já apresentada desde a unificação dos benefícios da Previdência Social na década de 60, o Plano de Pronta Ação dos anos 70 e as Ações Integradas de Saúde do início da década de $80 .^{1}$

Do ponto de vista gerencial, a adesăo dos trabalhadores de saúde, principalmente a dos médicos, é uma questão fundamental para que as instituições de saúde possam adequar-se ao modelo de atenção integral proposta pelo SUS. O papel diretivo desempenhado pelo médico o torna um ator organizacional de suma importância nessa nova ordem, sua alienação ou seu engajamento na estrutura das instituições de saúde representa a possibilidade ou não de viabilizar esse projeto integrador. $\mathrm{O}$ fato é que não há notícias de se ter inventado, no mundo ocidental, um sistema de saúde, um hospital, um pronto-socorro ou um ambulatório sem a presença demédi$\cos$. Eles são, por natureza de seu trabalho e serviços, essenciais à sociedade.

Entretanto, a falta de investimentos das instituiçōes públicas direcionados às atividades de informação e desenvolvimento de recursos humanos tem permitido que os profissionais direcionem seus interesses em sentido oposto ao preconizado pelo SUS. Sem exageros, podemos afirmar que a maior adesão dos médicos a tais objetivos resultaria em um impacto positivo nos padrōes de eficácia dos serviços prestados por eles; em aumento de integração do profissional com a equipe de saúde, diminuindo, assim, seu distanciamento do trabalho coletivo, bem como ampliando o grau de satisfação dos usuários.

Porém, qualquer análise de experiência de implementação da política de saúde não pode desconsiderar as percepçöes dos atores que exercem papel preponderante nas instituiçōes de saúde, percepções que se traduzem em representações sociais, elaboradas a partir de suas vivências quotidianas, lutas, enfrentamentos e dificuldades, centrais à construção de suas identidades profissionais. Tal avaliaçăo é importante na medida em que a ação dos médicos, dotada de uma relativa autonomia, não só influencia o perfil da própria assistência, como determina a existência ou não de conflitos na implementação das mudanças organizacionais propostas pelo SUS.

Embora reconheçamos que as opiniōes emitidas pelos médicos na pesquisa não representam efetivamente uma avaliação do SUS, acreditamos que possam contribuir para melhor compreender o processo em curso.

Para os médicos, a universalização da cobertura, independente da região em que ele está, é o sinal mais evidente das mudanças realizadas no sistema de saúde.

1 O sistema institucionalizado determina que as açōes e serviços públicos de saúde integrem uma rede regionalizada e hierarquizada e que constituam um sistema único, organizado de acordo com as seguintes diretrizes: primeiro, descentralização, com direção única em cada esfera de governo; segundo, atendimento integral, com prioridade para as atividades preventivas, sem prejuízo dos serviços assistenciais; e terceiro, participação da comunidade (BRAsIt, 1988). 
Para a maioria, a oferta de empregos não acompanhou a universalização, levando a uma sobrecarga de trabalho. A análise desta oferta, como se observou nos capítulos anteriores, aponta para o aumento de empregos somente nos setores estadual e municipal. A política de recursos humanos implementada no setor federal tem fomentado a não reposição das aposentadorias, demissões e afastamentos que ocorreram nestes últimos anos. O quadro acaba sendo de difícil solução: na esfera municipal, onde os salários quase sempre não são compensatórios, há maior instabilidade nas políticas de pessoal, já que os médicos tendem a não aceitar os empregos oferecidos no setor público.

O processo de municipalização vive hoje um grande dilema caracterizado por baixos salários e, em inúmeros casos, pela incerteza quanto à data do pagamento (atrasos de três a quatro meses têm sido comuns em vários municípios e estados do Brasil). Este fato tem levado ao surgimento do emprego de alta rotatividade. $\mathrm{O}$ fenômeno caracteriza-se pela demissão espontânea daqueles profissionais que, insatisfeitos com as condiçóes de trabalho oferecidas, se demitem, abrindo assim lugar para que ocorra a entrada de novatos, muitas vezes em serviços que exigem excelência técnica ou maior experiência profissional. Podemos dizer que estaria ocorrendo um 'rejuvenescimento forçado' do staff médico, em decorrência desta 'antipolítica' de recursos humanos adotada nas instituiçōes de saúde pública de um modo geral. O ciclo vicioso é entăo estabelecido:

A frase mais correta é: finge-se que trabalha e o Estado finge que paga.. Abandonei o serviço público após 16 anos. Pedi demissāo porque não mais disponho de horários para atender o ambulatório. (especialidade ignorada, feminino, 51 anos, CO)

Alia-se a essa situação o fato de que, na maioria dos municípios brasileiros, ocorre a efetiva impossibilidade financeira de repor a força de trabalho jubilada do setor federal. Esta talvez seja a questāo de recursos humanos que mais tem preocupado os gestores municipais, que se vêem pressionados a assumirem a funçāo e o papel de provedor e produtor de serviços de saúde em todos os níveis de complexidade assistencial. A opinião dos médicos reflete essa 'instabilidade' da estrutura municipal:

O SUS nāo existe. Todos nós sabemos que os serviços estaduais e municipais em sua grande maioria nunca tiveram bons antecedentes em termos de assistência e de arrecadaçāo. Os desmandos financeiros aumentaram agora que as verbas chegam mais fácil nas mãos dos políticos. (cirurgião geral, masculino, 46 anos, PE)

Desorganizados, sem liderança, sem garra, cedem logo e se tornam escravos, em parte, do poder político. O poder político diz que só paga ' $x$ ' aos médicos e derrotam os médicos, alegando que não podem pagar um salário condigno. Aos poucos, vencem os 'doutores' pela fafta de estrutura em ambas as partes. E permanece quase tudo obsoleto, arcaico, empurrando com a pança. (médico do trabalho, masculino, 63 anos, PR) 
Outros, mais radicais, desistem de tentar conciliar a dicotomia que se estabelece entre o ideal de servir e a realidade vivida.

O sistema de saúde no Brasil é tão caótico e a nossa classe é tão egoísta que me vi na 'obrigação' de abandonar a profissão antes que morresse enfartado. (intensivista, masculino, 60 anos, CO)

É importante dizer que me mantive até 1985 apenas com empregos públicos na área de saúde pública - por satisfação pessoal e salário suficiente. Depois, tive de complementar com consultório particular, que hoje é a principal fonte de renda porque o salário se reduziu a $15 \%$ do que era àquela época. (gineco-obstetra, masculino, 49 anos, SC)

Merecem destaque as manifestaçōes contrárias dos médicos em relação à autonomia no exercício profissional na estrutura do SUS. Igualmente insatisfatórias são as condiçōes de trabalho e o salário a que estão submetidos. A enorme burocracia estatal que acompanha os procedimentos AlHs, UCAs, CATs, ${ }^{2}$ Notificações Compulsórias etc. tem desestimulado os médicos a se vincularem ao SUS, visto que a remuneração por cada procedimento é, na opinião deles, muito aquém do limite aceitável. Aliam-se a isto as pressões sociais dos usuários, quase sempre justas, reivindicando melhor atendimento e assistência, conforto, segurança e qualidade nos serviços prestados, tanto nos hospitais como nos ambulatórios do sistema de saúde em geral. A opinião pública, por diversas vezes, tem se mostrado descontente com o atendimento prestado e acaba transferindo a sua contrariedade para a figura do médico.

O papel da mídia é outro aspecto a ser destacado. Freqüentemente posicionando-se de forma crítica diante da qualidade da assistência, ela acaba atuando como adversária, obscurecendo qualquer avanço obtido quanto à qualidade dos serviços prestados pelo SUS, especialmente em cidades de pequeno e médio portes. Isso assume maiores proporções quando, muitas vezes, a imprensa enfatiza seu mau desempenho, associando-o aos escândalos e denúncias que envolvem médicos. A insatisfação, nesses casos, é grande:

O que vamos fazer nas greves, rasgar o diploma? Esperar que a imprensa diga: - médico bonzinho, só está defendendo seu ganha-pāo! (pediatra, masculino, 34 anos, SC)

A imprensa joga a favor dos governantes, faz as pessoas pensarem que $o$ médico é o bandido, que ganha muito e não quer atender... (clínico geral, masculino, 28 anos, MT)

Desconfiança das propostas governamentais é uma das questões mais ressaltadas entre os médicos, o que, em última análise, significa dizer que a aliança entre a 'corporaçăo' e o 'Estado' tem sofrido severos abalos. Assim, eles se expressam:

2 Os dois primeiros (Autorização de Internação Hospitalar e Unidade de Cobertura Ambulatorial) estão vinculadas à remuneração pelo atendimento em saúde. CAT significa Comunicaçăo de Acidente de Trabalho, e as Notificaçōes Compulsórias referem-se ao Sistema de Vigilância à Saúde. 
E o Brasil tem algum sistema de saúde? O que eu vejo é a política na saúde. (clínico geral, masculino, 47 anos, RR)

\section{O DECLIINIO DO ARQUÉTIPO LIBERAL OU UM NOVO PROFISSIONAL?}

A prática médica, como expusemos no início do livro, pressupōe também, como princípio ético, uma relação ao mesmo tempo de confiança e credibilidade entre médico e paciente. A intimidade do profissional de medicina com os problemas dos clientes requer compreensão e sigilo. Estes últimos, quase sempre fragilizados, encontram-se pouco aptos a decidir o melhor para sua saúde e acatam os consethos médicos como ordens a serem cumpridas. O médico, por sua vez, segundo o Código Internacional de Ética Médica:

compromete-se perante a sociedade quanto à lealdade, honestidade, moralidade e respeito aos colegas e ao paciente, devendo sempre manter o mais alto nível profissional de conduta.

Os preceitos liberais são fortemente apreendidos pelos médicos, de modo que sua atuação no consultório ou em alguma instituição que o emprega é alicerçada em normas do típico profissional liberal. O Código de Ética Médica, em sua Resolução 1.246/88, é claro nesta questão:

Art. 7ㅇ - O médico deve exercer a profissăo com ampla autonomia, nāo sendo obrigado a prestar serviços profissionais a quem ele näo deseje, salvo na ausência de outro médico, em casos de urgência, ou quando sua negativa possa trazer danos irreversiveis ao paciente.

Art. $8^{\circ}$ - O médico não pode, em qualquer circunstância ou sob qualquer pretexto, renunciar à sua liberdade profissional, devendo evitar que quaisquer restriçōes ou imposições possam prejudicar a eficácia e correção de seu trabalho. (Conselho Federal de Medicina, 1990:16)

Tais preceitos săo fortemente introjetados, aceitos e decodificados diariamente pelos médicos, na busca de conciliar o que determina a 'boa medicina' e o fato de que terá que modificá-la positivamente em seu cotidiano. O médico os internaliza a despeito das conviç̧óes pessoais e dos constrangimentos ambientais, tendo ele que agir independente de acordo com os preceitos éticos que norteiam sua prática. Este é um dilema que cada um terá que enfrentar rotineiramente. Ser profissional liberal não é uma condição de mercado de trabalho, mas uma condição ideológica, constitutiva do arquétipo médico.

Entretanto, o retrato da profissão, diante do apelo ideológico da corporação, não responde ao esperado (Tabela 8.1). Os índices de rejeição ao projeto de modelo liberal são elevados. Vejamos, então, como os médicos, segundo a especialidade, respondem à indagaçăo quanto a se considerarem ou não profissionais liberais. 
Constata-se que as dez especialidades, nas quais os médicos mais se identificaram com a condição de profissional liberal, são caracterizadas pela forte autonomia técnica. Sejam especialidades cognitivas, em que a estreita relaçăo médico-paciente constitui traço característico (sexologia, homeopatia, geriatria, gerontologia), sejam as tecno-cirúrgicas, em que a autonomia técnica está associada a rendimentos mais elevados do que os auferidos em outras áreas (medicina nuclear, mastologia, cirurgia plástica, radioterapia e oftalmologia).

Tabela 8.1 - Médicos que se consideram liberais segundo especialidade. Brasil - 1995

\begin{tabular}{lc}
\hline \multicolumn{1}{c}{ Especialidades } & $(\%)$ \\
\hline Cognitivas & \\
\hline Sexologia & 100,0 \\
Homeopatia & 79,9 \\
Geriatria e Gerontologia & 69,0 \\
Psiquiatria & 66,0 \\
Hansenologia & 65,4 \\
Medicina esportiva & 64,4 \\
Neurologia pediátrica & 62,4 \\
Nutrologia & 58,3 \\
Cardiologia & 58,0 \\
Neurologia & 49,6 \\
Angiologia & 49,1 \\
Alergia e Imunoterapia & 48,0 \\
Pneumologia & 47,1 \\
Endocrinologia e Metabolia & 44,3 \\
Medicina geral comunitária & 42,8 \\
Medicina interna & 40,0 \\
Pediatria & 34,3 \\
Reumatologia & 31,6 \\
Medicina do trabalho & 30,0 \\
Genética clínica & 20,2 \\
Infectologia & 19,4 \\
Tisiologia & 1,7 \\
Foniatria & - \\
\hline Tecno-cirúrgicas & \\
\hline Mastologia & \\
\hline & \\
\hline & \\
\hline &
\end{tabular}


Tabela 8.1 - Médicos que se consideram liberais segundo especialidade. Brasil - 1995 (continuação)

\begin{tabular}{|c|c|}
\hline Especialidades & $(\%)$ \\
\hline Cirurgia plástica & 72,3 \\
\hline Cirurgia cardiovascular & 67,3 \\
\hline Neurocirurgia & 60,0 \\
\hline Cirurgia vascular & 57,0 \\
\hline Cirurgia de cabeça e pescoço & 55,1 \\
\hline Cirurgia geral & 46,5 \\
\hline Cirurgia torácica & 39,0 \\
\hline Cirurgia pediátrica & 33,9 \\
\hline Cirurgia da mão & 31,7 \\
\hline \multicolumn{2}{|l|}{ Intermediárias } \\
\hline Fisiatria & 83,0 \\
\hline Broncoesofagologia & 69,9 \\
\hline Oftalmologia & 67,3 \\
\hline Dermatologia & 64,5 \\
\hline Urologia & 63,1 \\
\hline Otorrinolaringologia & 61,5 \\
\hline Ortopedia e Traumatologia & 56,6 \\
\hline Cancerologia & 55,6 \\
\hline Endoscopia digestiva & 55,0 \\
\hline Gineco-Obstetrícia & 53,2 \\
\hline Hematologia & 52,7 \\
\hline Terapia intensiva & 51,6 \\
\hline Gastroenterologia & 49,9 \\
\hline Anestesiologia & 47,2 \\
\hline Proctologia & 46,8 \\
\hline Nefrologia & 36,7 \\
\hline Medicina legal & 12,4 \\
\hline \multicolumn{2}{|l|}{ Tecnológicas e burocráticas } \\
\hline Medicina nuclear & 79,5 \\
\hline Radioterapia & 68,2 \\
\hline Patologia clínica & 65,8 \\
\hline Citopatologia & 65,3 \\
\hline Patologia & 63,2 \\
\hline Eletroencefalografia & 57,8 \\
\hline
\end{tabular}


Tabela 8.1 - Médicos que se consideram liberais segundo especialidade: Brasil - 1995 (continuação)

\begin{tabular}{ll}
\hline \multicolumn{1}{c}{ Especialidades } & $(\%)$ \\
\hline Radiologia & 57,1 \\
Hemoterapia & 47,5 \\
Neurofisiologia clínica & 36,1 \\
Administração hospitalar & 35,8 \\
Medicina tráfego & 31,8 \\
Medicina sanitária & 18,4 \\
\hline TOTAL & 49,2 \\
\hline
\end{tabular}

Fonte: Pesquisa "Perfil dos Médicos no Brasil", Fiocruz/CFM.

Da mesma forma, observando aquelas especialidades em que os médicos, ao contrário, não se sentem profissionais liberais, vemos que, em boa parte, são áreas de atuação em que há uma forte e constante interferência no processo de trabalho médico. Isso se deve ao fato de que são especialidades predominantes, quase sempre, em organizações de saúde, atendendo à população usuária de forma mais 'coletiva' (medicina sanitária, medicina legal, tisiologia, infectologia, medicina do trabatho, por exemplo).

\section{PROFISSIONAL LIBERAL EM QUESTĀO}

Uma adesāo ideológica ou uma visōo realista?

A pesquisa mostra que $13,2 \%$ justificam a condição de profissional liberal pelo fato de não terem vínculo empregatício com nenhuma instituição.

Não tenho vínculo empregatício. Na rede privada trabalho através de firma de prestaçăo de serviços. (cirurgiaăo geral, feminino, 33 anos, SP)

Trabalho somente em consultório particular. (cirurgião cardiovascular, masculino, 49 anos, SP)

Porque não tenho emprego público, porque não tenho patrôes e minha renda é suficiente para meu sustento. (cirurgiāo geral, masculino, 45 anos, SP)

Não tenho vínculo de emprego, possuo relativa liberdade no exercício profissional. (ginecologista, masculino, 56 anos, PA)

A atividade em consultório assegura aos médicos, de um modo geral, o elo entre os preceitos ideológicos da profissão e sua condição no mercado de trabalho. A pesquisa mostra que $22,4 \%$ adotam essa postura liberal pelo fato de exercerem 
sua atividade em consultório, ou então passam a valorar sua condição de ser ou não liberal pelo fato de dedicarem-se mais à atividade de consultório.

Sou porque tenho mais de $50 \%$ da renda em consultório particular. (otorrinolaringologista, feminino, 42 anos, $\mathrm{AC}$ )

Porque minha atuação principal é no consultório, onde atendo pacientes em número que eu determino, a fim de preservar a relação médico-paciente. (dermatologista, masculino, 31 anos, $\mathrm{AL}$ )

Porque atuo em meu consultório particular em $70 \%$ do meu tempo e somente $30 \%$ no setor público. (obstetra, masculino, 43 anos, RR)

Porque trabalho praticamente em período integral em meu consultório particular (só dedico duas horas por dia ao meu único emprego. (cirurgião geral, feminino, 34 anos, MS)

Convencidos da idéia de que é possível separar o pensar do fazer, 10,9\% se consideram liberais por possuírem liberdade de conduta terapêtica, ou seja, autonomia técnica. Dessa forma, a capacidade técnica é que determina a ação profissional. Os constrangimentos ambientais são secundarizados na relação médico-paciente. $E$, assim, os médicos justificam a sua inclusão no grupo dos profissionais liberais

Porque tenho completa independência no direcionamento do meu trabalho. (cirurgião cardiovascular, masculino, 49 anos, SP)

Possuo liberdade na escolha da terapêutica ou na conduta diagnóstica mais adequada de acordo com minha formação. (pediatra, feminino, 42 anos, DF)

Porque no consultório rejo-me apenas pelos códigos de ética e por minhas decisōes pessoais, não me restrinjo a nenhuma influência governamental, a não ser as éticas. (dermatologista, masculino, 54 anos, AM)

Exerço minha profissão (especialidade) em local, condiçōes, horários até certo ponto por mim determinados. (radiologista, feminino, 42 anos, $\mathrm{GO}$ )

Ser ou não assalariado nessas circunstâncias não altera a auto-percepção em relação à autonomia profissional. A separação entre autonomia técnica e econômica é reafirmada freqüentemente pelos médicos:

Cumpro minha função de funcionário público sem submissāo. (ginecologista, masculino, 44 anos, $\mathrm{AL}$ )

Apesar de 'empregado', tenho condiçōes de pleno exercício da profissão, dentro, é claro, das condiçōes locais e da empresa. (pediatra, masculino, 46 anos, AP)

Porque desempenho livremente a minha profissăo sem qualquer tipo de pressão. (patologista, feminino, 46 anos, RR)

Na mesma linha argumentativa, observa-se que $8,7 \%$ dos médicos consideram-se liberais por poderem estabelecer sua carga horária e remuneração. Assim se manifestam em relação à administração da profissão: 
Dependo da iniciativa própria para determinar minha carga de trabalho. (obstetra, masculino, 35 anos, AC)

[Possuo] flexibilidade de horário, várias fontes de renda, trabalho por produtividade. (pediatra, masculino, 36 anos, AL)

TTenhol liberdade de escolha de honorário e possibilidade de várias atividades. (ginecologista, masculino, 65 anos, SP)

Os dados evidenciam, assim, um ideário liberal introjetado, o que faz com que haja, aparentemente, uma contradiçāo entre o ideal de servir e a realidade que lhes é dada. No entanto, quando mais de $20 \%$ dos médicos respondem que sua condição liberal está associada à liberdade de ir e vir, à autonomia para decidirem o melhor para o paciente, estão eles, na verdade, reafirmando aqueles princípios preconizados pelo Código de Ética Médica. Em suas palavras:

Abro consultório particular onde desejar. Aceito convênio ou não. Estabeleço clínica privada onde quiser. (psiquiatra, masculino, 55 anos, AL)

Posso ter meu consultório independente dos setores públicos e privados. (oftalmologista, masculino, 39 anos, AL)

Posso optar por diversos locais de trabalho e escolher entre eles o que methor favorecer minha atuação como médico. (oftalmologista, masculino, 26 anos, SP)

Posso trabalhar em outros hospitais, inclusive na rede privada, e tenho meus próprios rendimentos. (cirurgião cardiovascular, feminino, 43 anos, RR)

De forma contraditória, o sentimento de não pertencer ao grupo de médicos liberais está associado freqüentemente à condição de assalariamento. $A$ inserção no mercado de trabalho acaba por definir a importância da autonomia técnica e da autonomia econômica, sendo esta última o fator determinante para se optar em ser ou não um profissional liberal. E assim os médicos justificam não se considerarem como profissionais liberais:

Profissional liberal é aquele que ganha de acordo com sua produção, não sendo obrigado a trabalhar com carteira assinada para poder receber proventos mensais. (intensivista, feminino, 31 anos, $\mathrm{PB}$ )

Não me sinto porque minha atividade principal é no serviço público. Fora dele, vejo que a maior parte da sociedade não tem condiçōes de pagar honorários justos e ou adequados. (pediatra, masculino, 40 anos, PA)

Oitenta por cento dos meus rendimentos são oriundos de contratos com o governo estadual e municipal onde minha situação é de assalariada. (ginecologista, feminino, 32 anos, AM)

Porque vivo praticamente de empregos públicos, federal e estadual. (ginecologista, masculino, 56 anos, PA) 
Não tenho nenhuma renda afora o serviço público ao qual sou ligada, não tenho consultório, nem outro serviço que me caracterize como profissional liberal. (clínico geral, feminino, 41 anos, PB)

Associam, desse modo, dependência de empregos e falta de autonomia econômica à impossibilidade de se considerarem um típico profissional liberal. Assim, a autonomia econômica assume maior destaque no ideário de muitos médicos.

Sou vinculado ao senviço público e privado e dependo dele para sobreviver, em outras palavras, sou empregado. (clínico geral, masculino, 35 anos, AM)

O médico no Brasil tornou-se um empregado mal remunerado que ainda não dispōe das condiçōes ideais de trabalho. (pediatra, feminino, 26 anos, PB)

Cem por cento da minha renda depende de empregos. (pediatra, masculino, 46 anos, $\mathrm{CO})$

A dependência cada vez mais acentuada da atividade em consultório com os contratos de seguradoras de saúde, medicina de grupo etc., faz com que $10,5 \%$ dos médicos, mesmo tendo consultório, se sintam como 'liberais subempregados'. Os consultórios já não são, para um elevado número deles, um local privilegiado para o exercício da profissão liberal

A medicina é controlada por grupos mercantilistas (medicina de grupo) que levam o médico à submissão, com omissão governamental. (pediatra, masculino, 34 anos, SP)

No fundo sou um 'liberal subempregado' da medicina de grupo, seguro saúde, UNIMEDs. (cirurgião da cabeça e pescoço, masculino, 41 anos, PR)

Encontro-me dependente de um grupo privado para o qual presto serviço, sem completa autonomia, dependendo de autorização de convênios. (obstetra, masculino, 27 anos, DF)

Sobrevivo mediante salário de emprego público, onde sabemos que só ascende profissionalmente quem tem ' $Q I$ ', e dos pacientes da UNIMED, que tem suas regras próprias e só paga após trinta dias. (dermatologista, feminino, 32 anos, PA)

Sou subempregado, pois emprego sem salário digno não é emprego. $E$ mais, ganho menos de dez por cento de meus honorários diretamente do paciente. Maior renda surge da medicina de gnupo que me explora. (clínico geral, masculina, 43 anos, $M G$ )

Obedecer a uma hierarquia organizacional, estando sujeitos a normas estabelecidas, sem terem definidas as condições de trabalho, faz com que $12,5 \%$ dos médicos se sintam constrangidos em se definirem como profissionais liberais.

Nāo sou dono dos meus horários, sou obrigado a comparecer a todas as chamadas de urgência, em troca de valores ridículos que o governo paga como e quando quer. Não consigo tirar férias há quatro anos. (anestesiologista, masculino, 30 anos, SP) 
Tenho que me submeter as regras dos vários convênios, uma vez que não subsistiria com clientela exclusivamente particular. (pediatra, masculino, 55 anos, GO)

O sentimento de subordinação a normas, horários e procedimentos preestabelecidos, bem como a pouquíssima possibilidade de fazer escolhas pessoais na vida profissional, levam muitos médicos a experimentar um sentimento de subordinação absoluta, semelhante à condição de 'escravidão':

Sou escravo do paciente, do cirurgiāo e da instituição. Não determino meu horário, férias, dias de folga etc. (anestesiologista, masculino, 49 anos, MG)

Trabalho em medicina privada e estou sujeita à direção do hospital, não posso tomar decisōes em relação ao serviço, quando não concordo com o mesmo. (anestesiologista, feminino, 33 anos, PA)

No meu caso, sou médico do trabalho numa empresa, mas tenho ordens e horários a cumprir, trabalho em unidades de saúde da prefeitura, em município próximo a Curitiba, onde presto as mesmas obrigaçōes. (ginecologista, masculino, 27 anos, PR)

Não consigo exercer a profissăo livremente, d̀s vezes tenho que seguir as normas do hospital. (pediatra, feminino, 31 anos, PB)

Estou atrelada a inúmeras regras e implicações, além de ter vários patrōes e nāo poder estabelecer meus honorários. (clínico geral, feminino, 25 anos, SC).

Para os médicos, de um modo geral, a institucionalização da saúde e a maior burocratização das organizaçōes que os empregam têm determinado sua condição laboral e os transformado em profissionais com reduzida capacidade de atuar com autonomia, quer seja ela técnica ou econômica.

A maioria dos médicos têm algum tipo de vínculo empregatício (privado ou público) e quando têm atividade em consultório dependem de convênio e tabelas postos pelas empresas de grupo. (cirurgião geral, masculino, 31 anos, DF)

Trabalho liberal já não existe mais. Hoje somos diretamente funcionários de planos de saúde, cooperativas ou funcionários públicos. É dificil sobreviver só com consultas particulares. (pediatra, feminino, 33 anos, RS)

\title{
COM A PALAVRA: O MÉDICO
}

\author{
CAMPANHA NACIONAL: \\ Médicos exigem por 20 höras de serviços: ou o salário da \\ manicure do deputado ou o do ascensorista (chofer) do juiz!!! \\ (médico do trabalho, masculino, 32 anos, SC)
}

A realidade enfrentada diariamente pelos médicos brasileiros nos hospitais, ambulatórios e até mesmo nos seus consultórios tem produzido efeitos negativos em 
um número cada vez maior de profissionais. As condições de trabalho têm sido determinantes da forma como percebem o mundo de trabalho e como encaram a vida profissional:

Quando cheguei da residência, fui trabalhar numa clínica privada recém-inaugurada. Quando dava alta às crianças, não podia assinar a mesma na papeleta, pois isto era tarefa do dono da clínica. Ficava intrigada com isto, até que descobri que o motivo era que ele prescrevia mais dias para aumentar os lucros. Falei com um amigo dele, também pediatra, que trabalhava na coordenação médica do INAMPS. Este último, por sua vez, disse já saber de tudo e enfatizou que 'ladrão que rouba ladrão tem cem anos de perdão'. Esta foi minha primeira decepção, há vinte e cinco anos atrás. De lá para cá as coisas só pioraram. Naquela época, e também agora, quem não interessa muito é demitido (ou afastado). Tínhamos de inventar doenças, uma simples convulsāo febril virava meningite, uma amigdalite virava pneumonia e assim por diante. Como não aceitava isto, fui afastada dos hospitais privados. Então, fiquei só no serviço público. Imagine a minha tristeza quando um dia, revoltada com a produtividade, fomos, eu e outra colega de trabalho, à secretaria de Saúde e lá o chefe nos disse: - 'Sabe por que vocês ganham pouco? Porque não internam, e, quando o fazem, é uma pneumonia simples. Coloquem o código de pneumonia estafilocócica que paga mais'.

Assim, até no serviço público temos de inventar doentes e doenças. Está tudo perdido mesmo. Vejam só, o médico ganhar por produtividade, tem logica isso? Só se ganha mais quando se tem muitos doentes, entăo temos de lutar para que o número de doentes graves aumentem para melhorar nossa produtividade? Isto é um absurdo, nos formamos para combater doenças, mas para melhorar o salário temos de providenciar doentes. $E$ este o SUS que desejamos? Acho que não. Em I...l, existem quatro grandes hospitais privados, que atendem crianças, em convênio com o SUS. Públicos, so há dois e bem pequenos. Onde trabalho só tem uns cinqüenta leitos, se tiver, e não tem CTI. Toda reforma que é feita só piora mais, cada vez o número de leitos diminui mais, enquanto os convenentes crescem assustadoramente, mesmo com a diária péssima que o SUS paga. Que milagre é esse? Claro que é fazendo todo tipo de 'trambicagem'. As 'autoridades políticas' do País sabem de tudo e não fazem nada, porque os donos dos hospitais são também os donos do poder, quase todos são deputados estaduais ou federais, ou mesmo têm parentes nestes cargos, então o que fazer? Será que nós médicos temos de ser coniventes com tudo isso para podermos sobreviver? Cabe à classe, através do CFM, tomar uma atitude urgente coibindo este tipo de coisa. Dinheiro tem, só é mal empregado. Apesar de tudo, onde trabalho, dentro de nossas possibilidades, as crianças são bem tratadas. (médico) ${ }^{3}$

3 Dado o caráter deste depoimento-denúncia, optou-se por omitir as características do entrevistado. 
Săo inúmeros os depoimentos atestando a situação:

Conheço excelentes profissionais, extremamente competentes e inteligentes, que abandonaram a medicina, pois nāo conseguiram sobreviver e sustentar suas famílias com o que ganhavam. Outros só conseguem se manter através de empregos geralmente massacrantes e mal-remunerados, que nos tornam pessoas estressadas e médicos de má qualidade profissional, o que é ruim nāo só para nosso 'ego' como principalmente para a reputação que acaba difamada. Sinto-me péssima por fazer parte deste grupo que me faz correr o dia todo de um emprego para outro, sobrando pouco tempo para o consultório e nenhum tempo para mim - estudar, ler revistas médicas e de informação; para esportes, lazer e muito menos tempo para minha família. Ainda se isso compensasse realmente... Apenas me mantenho neste ritmo - me esgotando e fazendo o que não gosto - porque tenho muito medo de não conseguir ter o dinheiro suficiente para o básico de que necessito. Me sinto explorada e humilhada pelos empregadores e passada para trás pelos colegas da especialidade que, por mesquinharia e força política, conseguem convênios exclusivos, mantendo seus consultórios repletos e me deixando sem alternativas. (pediatra, feminino, 34 anos, SC)

O desprestígio e a perda de status acabam por afetar a forma como estes profissionais vão se relacionar não só com a sociedade em geral, mas certamente também com o paciente. O sentimento de desvalorização profissional é facilmente percebido na maioria dos médicos, ocasionando, assim, efetiva perda de auto-estima.

Me sinto humilhada, desvalorizada, explorada com o meu salário. Infelizmente dependemos de dinheiro para viver e nāo só de ideais. Dependo absolutamente de meu marido para ter um padrão de vida razoável e poder oferecer escola particular, lazer para meus filhos. Isto tem que mudar! (pediatra, feminino, 34 anos, ES)

Estamos relegados a um terceiro plano como tantos pequenos brasileiros, em detrimento das mordomias de promotores de justiça, juizes, políticos, empregados de estatais etc., que nada fazem, não resolvem nada para o povo, e, quando se aposentam, continuam sendo marajás. Falo isto porque conheço muitos dos que citei e que, muitas vezes, não têm nem sequer o curso secundário completo. (intensivista, masculino, 49 anos, MG)

A depressāo toma conta, pois o médico encontra-se atingido como pessoa e como profissional. Mas ainda há tempo. Na grande maioria, a classe médica é constituída de pessoas de grande 'élan', brio e de traços de caráter combativo e competente. Espero que as lideranças da classe possam retomar o tempo perdido. (cirurgião geral, masculino, 46 anos, $\mathrm{PE}$ )

Assim, como se pode depreender desta pequena amostra dos depoimentos extraídos dos questionários da pesquisa, os médicos demonstraram seu abatimento em relação ao futuro da profissão. Contemporâneos das profundas 
transformaçōes que estão ocorrendo no mundo do trabalho, apenas $18,5 \%$ deles afirmam conservar o otimismo (Tabela 8.2). A grande maioria oscila entre o pessimismo $(41,1 \%)$ e a incerteza $(17,3 \%)$.

Tabela 8.2 - Médicos por local de moradia segundo opinião sobre 'futuro da profissão'. Brasil - 1995

\begin{tabular}{lrc}
\hline \multicolumn{1}{c}{$\begin{array}{c}\text { Palavra que resume } \\
\text { o futuro da profissão }\end{array}$} & \multicolumn{2}{c}{ Brasil } \\
\cline { 2 - 3 } & \multicolumn{1}{c}{ v. abs. } & \multicolumn{1}{c}{$(\%)$} \\
\hline Pessimismo & 75.310 & 41,1 \\
Otimismo & 33.839 & 18,5 \\
Incerteza & 31.741 & 17,3 \\
Competência & 5.417 & 3,0 \\
Assalariamento & 5.769 & 3,2 \\
Tecnologia & 2.505 & 1,4 \\
Socializaçăo & 4.154 & 2,3 \\
Convênio & 1.787 & 1,0 \\
Não responderam & 22.530 & 12,3 \\
\hline TOTAL & 183.052 & 100,0 \\
\hline
\end{tabular}

Fonte: Pesquisa "Perfil dos Médicos no Brasil", Fiocruz/CFM.

Como já assinalamos, a profissão médica desenvolveu uma enorme capacidade de negociar privilégios e prerrogativas monopolistas para os que exercem tal atividade. Mostramos também como a profissão desenvolveu estratégias junto ao Estado e à sociedade para assegurar o status quo. No entanto, a realidade que os médicos vivem hoje no mundo do trabalho deixa dúvidas quanto a essa capacidade de negociação das entidades representativas da categoria diante de uma nova ordem de problemas surgidos. Desiludidos e pessimistas quanto ao futuro profissional, a corporação clama por medidas políticas que redefinam a agenda de recursos humanos para contemplar, de fato, seus interesses e necessidades. Resgatar a noção de que saúde e os que com ela trabalham são bens públicos é uma necessidade emergencial colocada hoje para as autoridades médicas e governamentais. 
Quadro resumo - Perfil dos médicos no Brasil - 1995

\begin{tabular}{|l|l|r|}
\hline \multicolumn{1}{|c|}{ Sócio-demográfico } & \multicolumn{1}{|c|}{ Descrição } & $(\%)$ \\
\hline Situação profissional & ativo & 92,6 \\
& abandono/afastamento & 2,0 \\
& aposentado & 2,0 \\
\hline Sexo & homens & 67,3 \\
& mulheres & 32,7 \\
\hline Faixa etária & menos de 45 anos & 65,8 \\
& mais de 60 anos & 8,6 \\
\hline Profissão do pai & médico & 7,4 \\
\hline Profissăo da mãe & médica & 0,7 \\
\hline
\end{tabular}

\begin{tabular}{|c|c|c|}
\hline Formação & Descrição & $(\%)$ \\
\hline Graduaçăo & $\begin{array}{l}\text { instituiçăo pública } \\
\text { instituição privada }\end{array}$ & $\begin{array}{l}66,4 \\
32,7\end{array}$ \\
\hline Tempo de formado & menos de 15 anos & 44,5 \\
\hline Residência médica & sim & 74,1 \\
\hline Curso de especializaçăo & $\operatorname{sim}$ & 40,7 \\
\hline Título de especialista & $\operatorname{sim}$ & 58,9 \\
\hline $\begin{array}{l}\text { Participação em congressos nos } \\
\text { últimos dois anos }\end{array}$ & $\operatorname{sim}$ & 73,6 \\
\hline $\begin{array}{l}\text { Assinatura revista } \\
\text { técnico-científica internacional }\end{array}$ & $\operatorname{sim}$ & 13,7 \\
\hline Filiação a sociedade científica & $\operatorname{sim}$ & 98,3 \\
\hline $\begin{array}{l}\text { Necessidade de aprimoramento } \\
\text { profissional }\end{array}$ & $\operatorname{sim}$ & 96,3 \\
\hline
\end{tabular}

\begin{tabular}{|l|l|r|}
\hline Inserção no mercado de trabalho & \multicolumn{1}{|c|}{ Descrição } & $(\%)$ \\
\hline Especialidade principal & Pediatria & 13,5 \\
& Gineco-Obstetrícia & 11,8 \\
& Medicina interna & 8,0 \\
& Cirurgia geral & 5,5 \\
& Anestesiologia & 5,2 \\
\hline Atividade no setor público & $\operatorname{sim}$ & 69,7 \\
\hline Atividade no setor privado & $\operatorname{sim}$ & 59,3 \\
\hline Atividade em consultório & $\operatorname{sim}$ & 74,7 \\
\hline Mantém convênios & $\operatorname{sim}$ & 79,1 \\
\hline
\end{tabular}


Quadro resumo - Perfil dos médicos no Brasil - 1995 (continuaçāo)

\begin{tabular}{|l|l|c|}
\hline Inserção no mercado de trabalho & \multicolumn{1}{|c|}{ Descriçāo } & $(\%)$ \\
\hline $\begin{array}{l}\text { Atividade médica em outro } \\
\text { município }\end{array}$ & sim & 26,2 \\
\hline Trabalha em regime de plantão & sim & 48,9 \\
\hline $\begin{array}{l}\text { Número de atividades } \\
\text { profissionais médicas }\end{array}$ & $\begin{array}{l}\text { até três atividades } \\
\text { mais de três atividades }\end{array}$ & 75,6 \\
\hline $\begin{array}{l}\text { Renda mensal com trabalho } \\
\text { médico }\end{array}$ & valor modal (em dólares) & $1.24,4$ \\
\hline Renda mensal desejada & valor modal (em dólares) & 4.608 \\
\hline $\begin{array}{l}\text { Piso salarial desejado para } \\
\text { 20 horas semanais }\end{array}$ & valor modal (em dólares) & 1.381 \\
\hline $\begin{array}{l}\text { Outras fontes de renda } \\
\text { (não-médicas) }\end{array}$ & sim & 13,5 \\
\hline
\end{tabular}

\begin{tabular}{|c|c|c|}
\hline Político-ideológico & Descrição & $(\%)$ \\
\hline $\begin{array}{l}\text { Conhecimento do código de } \\
\text { ética profissional }\end{array}$ & não & 16,5 \\
\hline $\begin{array}{l}\text { Opiniäo sobre trabalho médico } \\
\text { como 'atividade liberal' }\end{array}$ & $\operatorname{sim}$ & 49,2 \\
\hline $\begin{array}{l}\text { Opiniăo sobre desgaste } \\
\text { profissional }\end{array}$ & $\operatorname{sim}$ & 78,9 \\
\hline $\begin{array}{l}\text { Satisfação com a especialidade } \\
\text { que exerce }\end{array}$ & sim & 86,6 \\
\hline $\begin{array}{l}\text { Condição feminina como } \\
\text { obstáculo no trabalho }\end{array}$ & $\operatorname{sim}$ & 27,3 \\
\hline Filiação ao sindicato médico & $\operatorname{sim}$ & 44,9 \\
\hline Filiação à sociedade médica local & $\operatorname{sim}$ & 66,7 \\
\hline Conhecimento do Mercosul & $\operatorname{sim}$ & 73,7 \\
\hline Greve na saúde & $\begin{array}{l}\text { atendimento normal } \\
\text { atendimento emergência } \\
\text { não atendimento }\end{array}$ & $\begin{array}{r}16,5 \\
65,0 \\
4,4\end{array}$ \\
\hline $\begin{array}{l}\text { Opinião quanto ao futuro da } \\
\text { profissão }\end{array}$ & $\begin{array}{l}\text { visão otimista } \\
\text { visão pessimista }\end{array}$ & $\begin{array}{l}18,5 \\
41,1\end{array}$ \\
\hline
\end{tabular}





\section{CONSIDERAÇŌES METODOLÓGICAS SOBRE A PESQUISA "PERFIL DOS MÉDICOS NO BRASIL"}

Buscando conhecer e analisar a situação atual dos médicos no Brasil e subsidiar as entidades representativas da corporaçăo na formulação e reordenamento de políticas adequadas e compatíveis com a realidade destes profissionais no Sistema Único de Saúde (SUS), deu-se início, no final de 1993, às negociaçōes institucionais para a realização da pesquisa "Perfil dos Médicos no Brasil". De abrangência nacional, regional e estadual, a pesquisa contemplou o contingente de médicos no País, levando em conta a proporcionalidade de cada estado, permitindo traçar um perfil dos médicos com especificidades regionais.

Nessa mesma época, durante a II Conferência Nacional de Recursos Humanos, a Fundação Oswaldo Cruz foi consultada pelo Conselho Federal de Medicina, representado pelos seu vice-presidente, Dr. Crescêncio Antunes, e conselheiro, Dr. Antônio Henrique Pedrosa Neto, por intermédio do vice-presidente de Ensino da Fiocruz, Dr. Paulo Buss, a respeito da possibilidade de a Fundação elaborar e executar um projeto de pesquisa que permitisse ao Conselho maior conhecimento da situação dos médicos no Brasil. Desta forma, foi firmado um convênio entre a Fiocruz e o CFM para que se viabilizasse tal proposta. A operacionalização desse projeto se concretizou através do Núcleo de Estudos e Pesquisas em Recursos Humanos em Saúde do Departamento de Administração e Planejamento em Saúde da Escola Nacional de Saúde Pública.

Foram realizadas diversas reuniōes com o objetivo de desenvolver maior participação das entidades corporativas, bem como de ampliar os conteúdos e as propostas da referida pesquisa. Decidiu-se então convidar as entidades nacionais representativas da categoria - Associação Médica Brasileira (AMB), a Federaçāo Nacional dos Médicos (FENAM), os Conselhos Regionais e o Ministério da Saúde.

A partir de dezembro daquele mesmo ano, as reuniōes já contavam com a participação do conjunto de entidades médicas. Tendo sido aprovadas as linhas gerais da pesquisa, passou-se à elaboração do questionário. Este constituiu-se num dos 
momentos mais ricos do processo. Cada pergunta elaborada era submetida a intenso debate entre os representantes institucionais, para se avaliarem os objetivos e a forma de apresentação das mesmas.

A coordenação da pesquisa foi composta por uma coordenação geral (Fiocruz e CFM) e uma coordenação adjunta (com as demais instituiçōes participantes da pesquisa, incluindo o Ministério da Saúde). Em cada estado da Federação foi indicado, pelos Conselhos Federal e Regionais um representante que acompanhasse os procedimentos locais de divulgação e busca ativa de questionários, atuando como 'coordenador auxiliar'.

A sede do estudo esteve, durante toda sua realização, na Escola Nacional de Saúde Pública (equipe técnica) e no CFM (todos os procedimentos de informática, incluindo a expedição dos questionários).

Em março de 1994, buscou-se aplicar o pré-teste do instrumento de coleta de dados em três estados que refletissem as diversidades e complexidades da categoria médica no País. Desta forma, optou-se por São Paulo, Rio de Janeiro e Alagoas. Decidiu-se pela distribuição de quarenta questionários entre médicos escolhidos aleatoriamente em hospitais de grande porte e conselheiros dos Conselhos Regionais de Medicina. Foi solicitado que cada médico fizesse todas as observaçōes que julgasse convenientes sobre o conteúdo e a forma do questionário. As sugestōes foram posteriormente analisadas pela equipe técnica e discutidas com as entidades envolvidas.

A partir daí, foram cumpridos dois momentos metodológicos. No primeiro, caracterizou-se, através de um levantamento amostral do contingente ativo, ${ }^{1}$ o médico que atua no País, analisando-se desde os aspectos sócio-demográficos até os político-ideológicos - nesta fase foi definido o tamanho da amostra, realizada sua seleção, o trabalho de campo e, finalmente, a expansão da amostra. O segundo, que ocorreu simultaneamente em vários momentos, implicou o levantamento e a análise da bibliografia nacional e internacional sobre o tema.

O plano de amostragem buscou estabelecer tamanhos de amostras que permitissem fornecer estimativas independentes para as Unidades da Federaçâo, considerando, separadamente, capital e interior. Nos estados com mais de $70 \%$ do contingente médico residindo na capital, foi realizada a pesquisa somente neste local. É de fundamental importância observar que a exclusão dos 'interiores' que apresentaram menos de $30 \%$ dos médicos resultou na redução do universo a ser pesquisado, passando de 197.557 para 183.758 médicos. Desta forma, a amostra ficou assim desenhada: 'capital e interior': São Paulo*, Minas Gerais*, Espírito Santo, Rio Grande do Sul*, Paraná*, Santa Catarina, Distrito Federal (incluindo as cidades satélites),

1 Define-se como 'médico ativo' aquele que está regularmente inscrito no Conselho Regional de Medicina do respectivo estado e que não tenha formalmente pedido 'baixa' de sua inscrição profissional.

* As regiões metropolitanas desses estados foram incorporadas aos 'interiores'. 
Mato Grosso, Mato Grosso do Sul, Goiás*, Bahia*, Maranhão e Paraíba; 'capital': Rio de Janeiro, Amazonas, Pará, Alagoas, Rio Grande do Norte, Piauí, Sergipe, Pernambuco e Ceará; 'interior': Tocantins. Nos estados do Acre, Amapá, Roraima, Rondônia e na capital de Tocantins, decidiu-se por censo, dado que o pequeno volume de médicos nestes locais inviabilizou a realização de amostra.

Baseando-se no cadastro do Conselho Federal de Medicina e levando em consideração o escopo, abrangência e condiçóes objetivas da pesquisa, optou-se pela amostragem aleatória simples. As amostras foram dimensionadas com o objetivo de alcançar a mesma precisão e confiabilidade desejadas para capital e interior, considerando-se as proporções. Para a seleção utilizou-se a seleção sistemática, com a listagem de todos os médicos por ano de formado.

O plano de amostragem elaborado consistiu de amostras independentes para a capital e o interior, quando se desejavam estimativas independentes para estes dois subconjuntos, sem desagregação por gênero.

Assim a amostra total selecionada para a pesquisa foi de 14.383 médicos. Considerando os estados onde foram realizados censos, o número de médicos pesquisado foi de $15.488,{ }^{2}$ distribuídos por todo o território nacional.

A determinação do tamanho da amostra foi feita considerando-se $p=q=0,5$, $95 \%$ de confiabilidade e erro de amostragem de aproximadamente $4,5 \%$, pois além do cadastro nảo possuir registros que permitissem a sua utilização para melhorar o modelo de amostragem, o questionário utilizado apresentava muitas questões dicotômicas, o que justificava plenamente o critério adotado.

Um outro aspecto a ser ressaltado é a fração de amostragem - relação entre tamanho da amostra e tamanho da população. Exemplificando: considere-se o estado de Sáo Paulo, onde para a capital tem-se como numerador o tamanho da amostra, que foi de 493; e no denominador, o número de médicos dentre a população local, 30.061. A razão entre os dois foi aproximadamente 1/61. No interior, a fração foi de $1 / 48$. Isto significa que um médico na amostra daquela capital representava 61 médicos na população, enquanto que no interior um médico respondia por 48 .

Quando do planejamento amostral, procurou-se manter em níveis relativamente próximos os erros de amostragem para as duas subpopulaçōes. Na capital paulista o erro esperado estimado era de $4,43 \%$ e, no interior, de $4,41 \%$, resultando, conseqüentemente, em fraçōes de amostragem diferentes. Assim, as fraçöes de amostragem foram diferentes para capitais e interiores de cada Unidade da Federação (Tabela 1).

2 A população de médicos ativos nas capitais era de 121.130 e, nos interiores, de 62.430 , segundo os dados do cadastro fornecido pelo CFM, atualizados até setembro de 1994 e utilizados para a seleção da amostra. 
Tabela 1 - Fraçōes de amostragem e erros de amostragem esperados por Unidade da Federaçăo. Brasił - 1995

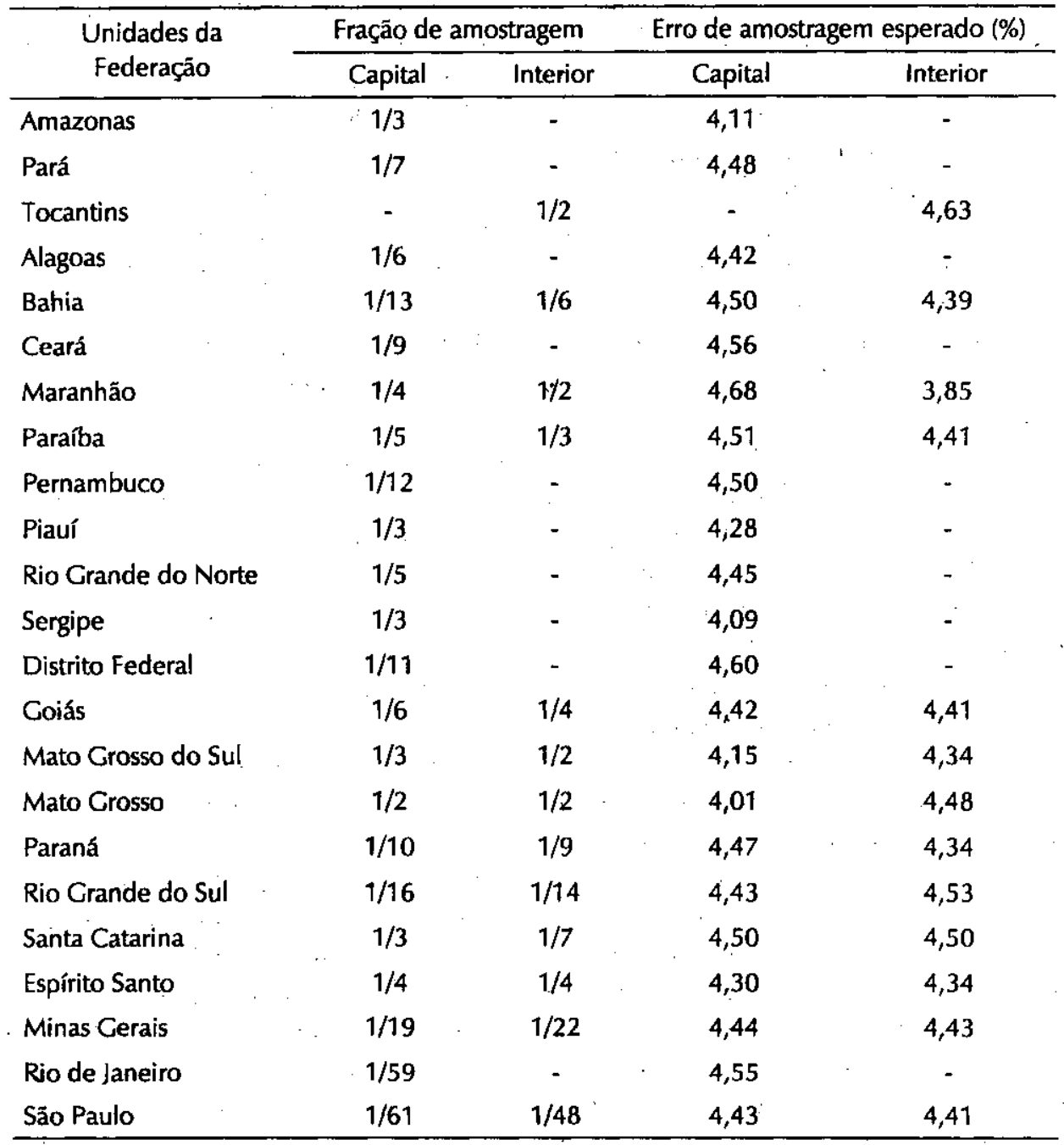

Fonte: Pesquisa "Perfil dos Médicos no Brasil", Fiocruz/CFM.

Uma vez determinados os tamanhos das amostras, começou a fase de seleção. Inicialmente, foram tomadas algumas medidas quanto ao cadastro do Conselho Federal de Medicina utilizado na pesquisa, visando a torná-lo compatível com o escopo do estudo. A primeira foi a eliminação do duplo registro (inscrição secundária), verificado, por exemplo, quando médicos trabalham em mais de um estado (Rio de Janeiro e São Paulo ou Paraíba e Pernambuco, dentre outros casos) ou se encontram 
em processo de transferência de moradia. Estas medidas ajudaram a reduzir a probabilidade de serem selecionados médicos com dupla inscrição. Uma segunda medida foi a exclusão, após exaustiva pesquisa de arquivo junto ao Núcleo de Computação do Conselho Federal de Medicina, dos profissionais sem informações, ou seja, daqueles que constavam no cadastro, porém sem atualizarem, por muito tempo, o endereço de correspondência. Incluiam-se nessa modalidade, entre outros, os médicos falecidos (sem registro de falecimento) e os inadimplentes há vários anos no Conselho Regional.

Em seguida, foi necessário um reordenamento do cadastro, visto que seria utilizada uma seleção sistemática, a qual pôde, de certa forma, funcionar como uma estratificação. A organização do cadastro foi feita construindo-se dois conjuntos, um de homens e outro de mulheres e dentro de cada conjunto, os médicos foram listados do mais antigo para o mais novo, por tempo de formado. Muito embora a pesquisa não tivesse tido por objetivo fornecer estimativas desagregadas por gênero, a seleção da amostra foi feita levando-se em conta este aspecto, assim como a data de formatura. A adoção desta estratégia evitaria a introdução de tendências por ocasião da seleção da amostra.

Na capital, este procedimento pôde ser adotado, porém, no interior, surgiu um novo problema, a ordem dos municípios para efeito de seleção. A solução foi adotar as microrregióes homogêneas ${ }^{3} \mathrm{e}$, dentro de cada microrregiăo, adotar um sentido de percurso que estabelecia a ordem dos municípios no cadastro. Às regiões metropolitanas - que são formadas pelo município da capital e por municípios da periferia - juntou-se o interior dos municípios da periferia, porém de forma que pudessem ser facilmente identificáveis. Este procedimento evidentemente só foi necessário nos casos em que o interior do estado seria pesquisado. Nas situações em que se pesquisou apenas a capital, a região metropolitana foi agregada àquela.

Os pontos acima citados foram utilizados para permitir, caso houvesse interesse, a ampliaçăo da amostra para determinada microrregiáo ou mesmo região metropolitana, sem prejuízo do que tivesse sido pesquisado.

\section{O INSTRUMENTO DE COLETA DE DADOS}

Para realização da pesquisa foi utilizado um questionário específico contendo perguntas objetivas e subjetivas, divididas em sete blocos. ${ }^{4} \mathrm{O}$ primeiro tratando de

3 Estes municípios foram trabalhados tomando-se por base as microrregiōes homogeneas definidas pelo IBGE, de forma que cada microrregiăo homogênea passou a constituir uma subpopulação. Como os munićpios pertencentes as microrregiōes homogêneas são listados, pelo IBCE, por ordem alíabética, adotou-se o procedimento de dispó-los em ordem geográfica, o que permitiria um maior espalhamento da amostra.

4 Para maiores informaçōes, ver: MACHADO et al. (1996, v.1), onde se encontra o questionário enviado aos médicos. 
identificação - sexo, local de residência, nacionalidade, naturalidade, idade, parentesco médico, profissão dos pais. $O$ segundo abrangendo formação profissional instituição formadora, ano de conclusão, realização de estágio profissional, de cursos quer lato (especialização e residência) ou stricto sensu (mestrado, doutorado, pósdoutorado) - e até mesmo se participou de congressos científicos e seminários. $O$ terceiro enfocando questōes relativas ao acesso a revistas científicas nacionais e internacionais, à participação em sociedades científicas e à necessidade de aprimorar os conhecimentos.

No bloco quatro tratou-se do mercado de trabalho, sendo levantadas questões sobre o ambiente de trabalho (se trabalha em consultório; se participa de alguma cooperativa e/ou mantém convênios com o SUS, medicina de grupo, seguro saúde, UNIMED, entre outros; se tem vínculos empregatícios no setor público ou privado; se trabalha em plantão), a área de especialização em que atua e as condições de trabatho (jornada de trabalho, salários, regimes de trabalho, multiemprego), entre outras. No quinto verificou-se a questão de gênero - a mulher no exercício da profissão.

O sexto levantou informações sobre a participaçăo sócio-política do médico: a auto-percepção da profissão (atividade liberal, autonomia, ideal de trabalho), a questão da ética profissional (a ética do trabalho e a ética no trabalho), as greves nos serviços de saúde e a prática médica, a participação dos médicos nas entidades corporativas (conselhos, sindicatos, sociedades científicas), a perspectiva profissional (realização e satisfação no trabalho, idealização do futuro profissional e da própria profissão). No sétimo e último bloco, perguntou-se aos médicos se eles tinham conhecimento do acordo Mercosul e pediu-se que opinassem sobre os problemas que consideravam prioritários para serem tratados pelas entidades.

Para efeito deste livro, nem todas as informaçōes do questionário foram analisadas. Privilegiaram-se as principais questões sobre mercado de trabalho, formação médica e características sócio-políticas do médico.

A pesquisa de campo começou no primeiro semestre de 1994 e terminou no início do ano seguinte. O questionário foi enviado pelo correio, junto com uma carta de apresentação assinada pelos presidentes do CFM, AMB e FENAM, e um outro envelope, com porte pago, já endereçado ao CFM para retorno. Em nenhum momento o médico selecionado teve que se identificar, pois um sistema de código de barra utilizado no envelope de devolução, garantiu-lhe o anonimato.

$\mathrm{O}$ apoio dos Conselhos Regionais de Medicina foi fundamental na fase de coleta da informação. Em cada estado da Federação houve um coordenador de campo que acompanhou todo o trabalho, assegurando a cobertura do contingente amostral, a precisão da coleta, a qualidade e o rigor na devolução correta dos questionários (Tabela 2).

Dada a magnitude da pesquisa e a adoção da metodologia de aplicação dos questionários por correio, bem como o fato de contar com uma reduzida equipe técnica centralizada na Fiocruz, a coordenação técnica, para que os objetivos fossem atingidos com êxito, optou por desenvolver mecanismos, técnicas e instrumen- 
Tabela 2 - Índice de devolução dos questionários por local de moradia segundo Unidades da Federação. Brasil - 1995

\begin{tabular}{|c|c|c|c|}
\hline \multirow{2}{*}{$\begin{array}{c}\text { Grandes Regiōes e } \\
\text { Unidades da Federação }\end{array}$} & \multicolumn{3}{|c|}{ Índice de Devolução (\%) } \\
\hline & Capital & Interior & TOTAL \\
\hline REGIÄO NORTE & 41,4 & 50,2 & 43,5 \\
\hline Acre & 38,0 & 23,8 & 35,0 \\
\hline Amazonas & 41,4 & - & - \\
\hline Amapá & 39,8 & 100,0 & 43,3 \\
\hline Pará & 40,8 & - & - \\
\hline Rondônia & 49,2 & 53,1 & 51,1 \\
\hline Roraima & 34,8 & 100,0 & 37,5 \\
\hline Tocantins & 43,5 & 47,8 & 46,8 \\
\hline REGIĀO NORDESTE & 42,9 & 42,9 & 42,9 \\
\hline Alagoas & 43,7 & - & - \\
\hline Bahia & 54,0 & 55,8 & 54,9 \\
\hline Ceará & 41,0 & - & - \\
\hline Maranhăo & 37,4 & 32,7 & 35,1 \\
\hline Paraíba & 32,7 & 34,9 & 33,7 \\
\hline Pernambuco & 49,2 & - & - \\
\hline Piauí & 47,9 & - & - \\
\hline Rio Grande do Norte & 45,7 & - & - \\
\hline Sergipe & 31,0 & - & - \\
\hline RECIÃO SUDESTE & 63,7 & 65,3 & 64,4 \\
\hline Minas Gerais & 57,1 & 58,9 & 58,0 \\
\hline Espírito Santo & 66,2 & 78,3 & 72,1 \\
\hline Rio de Janeiro & 53,3 & - & - \\
\hline São Paulo & 77,7 & 61,7 & 69,1 \\
\hline RECIĀO CENTRO-OESTE & 59,4 & 51,7 & 56,5 \\
\hline Distrito Federal & 80,6 & - & - \\
\hline Goiás & 48,5 & 54,3 & 51,2 \\
\hline Mato Grosso do Sul & 50,7 & 56,3 & 53,1 \\
\hline Mato Grosso & 56,3 & 43,5 & 50,6 \\
\hline REGIĀO SUL & 53,9 & 54,0 & 53,9 \\
\hline Paraná & 53,2 & 53,5 & 53,4 \\
\hline Rio Grande do Sul & 47,4 & 50,2 & 48,8 \\
\hline Santa Catarina & 61,3 & 58,8 & 60,0 \\
\hline BRASIL & 50,6 & 54,0 & 51,8 \\
\hline
\end{tabular}

Fonte: Pesquisa "Perfil dos Médicos no Brasil", Fiocruz/CFM. 
tos, de certa forma 'pouco ortodoxos no meio acadêmico'. Desta forma, participaram de forma importante, contribuindo, decisivamente, as direçōes das entidades médicas nacionais (CFM, AMB, FENAM), dos conselhos, dos sindicatos e sociedades regionais, assim como a imprensa nacional e regional. Enfim, a estratégia de mobilização e participação dos médicos nesta pesquisa foi intensa e, certamente, responsável pelo sucesso incontestável do retorno dos questionários respondidos.

Alguns dos procedimentos adotados foram: a) carta de conscientizaçăo assinada pelos presidentes das três entidades médicas nacionais (CFM, AMB e FENAM), esclarecendo a importância e solicitando aos médicos selecionados a colaboração para o êxito da pesquisa; b) divulgaçāo exaustiva na imprensa, por meio do órgão oficial de divulgação da Presidência da República. Utilizous-se, por quinze dias, o horário gratuito do Ministério da Saúde, em todas as emissoras de rádio e televisão, excetuando as associadas à Rede Clobo de Televisão, que apresentou argumentos burocráticos para não veicular o referido anúncio da pesquisa. ${ }^{5}$ Da mesma forma, cartazes, entrevistas, reportagens foram exaustivamente usados (em nivel regional e nacional) como recursos para a maior participação dos médicos em todo o País; c) notas metodológicas, contendo os procedimentos em caso de dúvidas no preenchimento e/ou retorno dos questionários, discriminando, inclusive, o tipo de encaminhamento em casos de possíveis substituiçōes de médicos na amostra, quando necessário; d) diário de campo, envio semanal do quadro-resumo do retorno dos questionários. Este quadro continha: número de questionários devolvidos, a devolver e total de questionários enviados (para capital, interior e total geral para cada estado da Federação); e) por último, memória de campo, tendo sido elaborado um questionário aos coordenadores em cada estado (representante do Conselho Regional de Medicina), no qual se buscou registrar e avaliar todo o trabalho desenvolvido por eles ao longo da pesquisa.

Quando iniciada a etapa de devolução dos questionários, procedeu-se a uma série de procedimentos de verificação e conferência para manter o controle da qualidade e quantidade dos mesmos. Após esta etapa, deu-se início ao processamento dos dados. Para a digitação dos questionários, adotaram-se as seguintes medidas: elaboração de plano de entrada de dados, elaboração de plano de consistência dos dados e dupla digitaçâo.

Todo o processo de codificação de questionários, controle de devolução, envio e reenvio foram realizados nas dependências do CFM em Brasília, através de sua equipe de informática, com o acompanhamento da equipe de pesquisadores da Fiocruz. Paralelamente à digitação e à conferência das questões fechadas e semi-abertas do questionário, procedeu-se à leitura e codificação das questões abertas.

Após finalizar essa etapa, passou-se à expansão dos resultados da amostra. Para isso, foram calculadas os fatores de expansão da amostra, dividindo o total de médicos da população pelo total devolvido.

5 A Rede Clobo não veicula na mídia gratuita anúncio assinado por mais de uma entidade. 
A expansão da amostra foi feita separadamente para capital e interior de cada Unidade da Federação, considerando-se a distribuição etária, em nove grupos de idade e sexo, perfazendo assim dezoito fatores para a capital e igual número para o interior. Desta forma, o universo analisado foi de '183.052' médicos. O procedimento de expansão foi elaborado, considerando-se critérios específicos para as diferentes regiōes. ${ }^{6}$

Tabela 3 - Erro absoluto e relativo para as estimativas de total. Brasil, Capitais - 1995

\begin{tabular}{|c|c|c|c|c|c|}
\hline & & & & $\mathrm{n}=5.085$ & $N=120.662$ \\
\hline TOTAL & $\begin{array}{l}\text { Desvio } \\
\text { padräo } \\
\text { (Total) }\end{array}$ & $\begin{array}{c}\text { (2x) Desvio } \\
\text { padräo } \\
\text { (Total) }\end{array}$ & $\begin{array}{l}\text { Limite } \\
\text { inferior }\end{array}$ & $\begin{array}{l}\text { Limite } \\
\text { superior }\end{array}$ & $\begin{array}{l}\text { Coeficiente } \\
\text { de variação }\end{array}$ \\
\hline 1.207 & 215 & 431 & 776 & 1.637 & 0,1784 \\
\hline 6.033 & 472 & 943 & 5.090 & 6.976 & 0,0782 \\
\hline 12.066 & 649 & 1.298 & 10.768 & 13.365 & 0,0538 \\
\hline 18.099 & 773 & 1.545 & 16.554 & 19.645 & 0,0427 \\
\hline 24.132 & 866 & 1.731 & 22.401 & 25.864 & 0,0359 \\
\hline 30.166 & 937 & 1.874 & 28.291 & 32.040 & 0,0311 \\
\hline 36.199 & 992 & 1.983 & 34.215 & 38.182 & 0,0274 \\
\hline 42.232 & 1.032 & 2.064 & 40.167 & 44.296 & 0,0244 \\
\hline 48.265 & 1.060 & 2.120 & 46.145 & 50.385 & 0,0220 \\
\hline 54.298 & 1.077 & 2.153 & 52.145 & 56.451 & 0,0198 \\
\hline 60.331 & 1.082 & 2.164 & 58.167 & 62.495 & 0,0179 \\
\hline 66.364 & 1.077 & 2.153 & 64.211 & 68.517 & 0,0162 \\
\hline 72.397 & 1.060 & 2.120 & 70.277 & 74.517 & 0.0146 \\
\hline 78.430 & 1.032 & 2.064 & 76.366 & 80.495 & 0.0132 \\
\hline 84.463 & 992 & 1.983 & 82.480 & 86.447 & 0,0117 \\
\hline 90.497 & 937 & 1.874 & 88.622 & 92.371 & 0,0104 \\
\hline 96.530 & 866 & 1.731 & 94.798 & 98.261 & 0,0090 \\
\hline 102.563 & 773 & 1.545 & 101.017 & 104.108 & 0,0075 \\
\hline 108.596 & 649 & 1.298 & 107.297 & 109.894 & 0,0060 \\
\hline 114.629 & 472 & 943 & 113.686 & 115.572 & 0,0041 \\
\hline 119.455 & 215 & 431 & 119.025 & 119.886 & 0,0018 \\
\hline
\end{tabular}

Fonte: Pesquisa "Perfil dos Médicos no Brasil", Fiocruz/CFM.

6 Devido ao escopo deste livro não cabe aqui detalhar ainda mais os processos metodológicos adotados. Para maiores informaçōes năo só sobre a metodologia, mas também sobre o plano de amostragem, a seleção e expansão da amostra e o erro amostral, sugere-se a leitura do mencionado Relatório Final da "Pesquisa Perfil dos Médicos no Brasil" (Machado et al., 1996). 
Tabela 4-Erro absoluto e relativo para as estimativas de total. Brasil, Interiores - 1995

\begin{tabular}{|c|c|c|c|c|c|}
\hline & & & & $n=2.939$ & $N=62.390$ \\
\hline TOTAL & $\begin{array}{l}\text { Desvio } \\
\text { padrão } \\
\text { (Total) }\end{array}$ & $\begin{array}{c}\text { (2x) Desvio } \\
\text { padrāo } \\
\text { (Total) }\end{array}$ & $\begin{array}{l}\text { limite } \\
\text { inferior }\end{array}$ & $\begin{array}{l}\text { Limite } \\
\text { superior }\end{array}$ & $\begin{array}{l}\text { Coeficiente } \\
\text { de variação }\end{array}$ \\
\hline 624 & 141 & 282 & 342 & 905 & 0,2256 \\
\hline 3.120 & 308 & 616 & 2.503 & 3.736 & 0,0988 \\
\hline 6.239 & 424 & 848 & 5.391 & 7.087 & 0,0680 \\
\hline 9.359 & 505 & 1.010 & 8.349 & 10.368 & 0,0540 \\
\hline 12.478 & 566 & 1.131 & 11.347 & 13.609 & 0,0453 \\
\hline 15.598 & 612 & 1.225 & 14.373 & 16.822 & 0,0393 \\
\hline 18.717 & 648 & 1.296 & 17.421 & 20.013 & 0,0346 \\
\hline 21.837 & 674 & 1.349 & 20.488 & 23.185 & 0,0309 \\
\hline 24.956 & 693 & 1.386 & 23.570 & 26.342 & 0,0278 \\
\hline 28.076 & 703 & 1.407 & 26.669 & 29.482 & 0,0251 \\
\hline 31.195 & 707 & 1.414 & 29.781 & 32.609 & 0,0227 \\
\hline 34.315 & 703 & 1.407 & 32.908 & 35.721 & 0,0205 \\
\hline 37.434 & 693 & 1.386 & 36.048 & 38.820 & 0,0185 \\
\hline 40.554 & 674 & 1.349 & 39.205 & 41.902 & 0,0166 \\
\hline 43.673 & 648 & 1.296 & 42.377 & 44.969 & 0,0148 \\
\hline 46.793 & 612 & 1.225 & 45.568 & 48.017 & 0,0131 \\
\hline 49.912 & 566 & 1.131 & 48.781 & 51.043 & 0,0113 \\
\hline 53.032 & 505 & 1.010 & 52.022 & 54.041 & 0,0095 \\
\hline 56.151 & 424 & 848 & 55.303 & 56.999 & 0,0076 \\
\hline 59.271 & 308 & 616 & 58.654 & 59.887 & 0,0052 \\
\hline 61.766 & 141 & 281 & 61.485 & 62.047 & 0,0023 \\
\hline
\end{tabular}

Fonte: Pesquisa "Perfil dos Médicos no Brasil", Fiocruz/CFM. 
Tabela 5 - Erro absoluto e relativo para as estimativas de total. Brasil, Total - 1995

\begin{tabular}{|c|c|c|c|c|c|}
\hline & & & & $\mathrm{n}=8.024$ & $N=183.052$ \\
\hline TOTAL & $\begin{array}{l}\text { Desvio } \\
\text { padrão } \\
\text { (Total) }\end{array}$ & $\begin{array}{c}\text { (2x) Desvio } \\
\text { padrăo } \\
\text { (Total) }\end{array}$ & $\begin{array}{l}\text { Limite } \\
\text { inferior }\end{array}$ & $\begin{array}{l}\text { Limite } \\
\text { superior }\end{array}$ & $\begin{array}{l}\text { Coeficiente } \\
\text { de variação }\end{array}$ \\
\hline 1.831 & 257 & 514 & 1.316 & 2.345 & 0,1405 \\
\hline 9.153 & 563 & 1.127 & 8.026 & 10.279 & 0,0616 \\
\hline 18.305 & 776 & 1.551 & 16.754 & 19.856 & 0.0424 \\
\hline 27.458 & 923 & 1.846 & 25.612 & 29.304 & 0,0336 \\
\hline 36.610 & 1.034 & 2.068 & 34.542 & 38.678 & 0,0282 \\
\hline 45.763 & 1.119 & 2.239 & 43.524 & 48.002 & 0,0245 \\
\hline 54.916 & 1.185 & 2.369 & 52.546 & 57.285 & 0,0216 \\
\hline 64.068 & 1.233 & 2.466 & 61.602 & 66.534 & 0,0192 \\
\hline 73.221 & 1.266 & 2.533 & 70.688 & 75.754 & 0,0173 \\
\hline 82.373 & 1.286 & 2.572 & 79.801 & 84.945 & 0,0156 \\
\hline 91.526 & 1.293 & 2.585 & 88.941 & 94.111 & 0,0141 \\
\hline 100.679 & 1.286 & 2.572 & 98.107 & 103.251 & 0,0128 \\
\hline 109.831 & 1.266 & 2.533 & 107.298 & 112.364 & 0,0115 \\
\hline 118.984 & 1.233 & 2.466 & 116.518 & 121.450 & 0,0104 \\
\hline 128.136 & 1.185 & 2.369 & 125.767 & 130.506 & 0,0092 \\
\hline 137.289 & 1.119 & 2.239 & 135.050 & 139.528 & 0,0082 \\
\hline 146.442 & 1.034 & 2.068 & 144.374 & 148.510 & 0,0071 \\
\hline 155.594 & 923 & 1.846 & 153.748 & 157.440 & 0,0059 \\
\hline 164.747 & 776 & 1.551 & 163.196 & 166.298 & 0,0047 \\
\hline 173.899 & 563 & 1.127 & 172.773 & 175.026 & 0,0032 \\
\hline 181.221 & 257 & 514 & 180.707 & 181.736 & 0,0014 \\
\hline
\end{tabular}

Fonte: Pesquisa "Perfil dos Médicos no Brasil", Fiocruz/CFM. 
Tabela 6 - Erro absoluto e relativo na estimaçáo da proporção "P". Brasil, Capitais - 1995

\begin{tabular}{cccccc}
$\begin{array}{c}\text { Proporção } \\
\text { amostral }\end{array}$ & $\begin{array}{c}\text { Desvio } \\
\text { padrão }(\mathrm{P})\end{array}$ & $\begin{array}{c}(2 \mathrm{x}) \text { Desvio } \\
\text { padräo }(\mathrm{P})\end{array}$ & $\begin{array}{c}\text { Limite } \\
\text { inferior }\end{array}$ & $\begin{array}{c}\text { Limite } \\
\text { superior }\end{array}$ & $\begin{array}{c}\text { Coeficiente } \\
\text { de variação }\end{array}$ \\
\hline 0,20 & 0,0056 & 0,0112 & 0,1888 & 0,2112 & 0,0280 \\
0,25 & 0,0061 & 0,0121 & 0,2379 & 0,2621 & 0,0243 \\
0,30 & 0,0064 & 0,0129 & 0,2871 & 0,3129 & 0,0214 \\
0,35 & 0,0067 & 0,0134 & 0,3366 & 0,3634 & 0,0191 \\
0,40 & 0,0069 & 0,0137 & 0,3863 & 0,4137 & 0,0172 \\
0,45 & 0,0070 & 0,0140 & 0,4360 & 0,4640 & 0,0155 \\
0,50 & 0,0070 & 0,0140 & 0,4860 & 0,5140 & 0,0140 \\
0,55 & 0,0070 & 0,0140 & 0,5360 & 0,5640 & 0,0127 \\
0,60 & 0,0069 & 0,0137 & 0,5863 & 0,6137 & 0,0115 \\
0,65 & 0,0067 & 0,0134 & 0,6366 & 0,6634 & 0,0103 \\
0,70 & 0,0064 & 0,0129 & 0,6871 & 0,7129 & 0,0092 \\
0,75 & 0,0061 & 0,0121 & 0,7379 & 0,7621 & 0,0081 \\
0,80 & 0,0056 & 0,0112 & 0,7888 & 0,8112 & 0,0070 \\
\hline
\end{tabular}

Fonte: Pesquisa "Perfil dos Médicos no Brasil", Fiocruz/CFM.

Tabela 7 - Erro absoluto e relativo na estimação da proporção "P". Brasil, Interiores - 1995

\begin{tabular}{cccccc}
\hline $\begin{array}{c}\text { Proporção } \\
\text { amostral }\end{array}$ & $\begin{array}{c}\text { Desvio } \\
\text { padrāo }(\mathrm{P})\end{array}$ & $\begin{array}{c}(2 \times) \text { Desvio } \\
\text { padrão }(\mathrm{P})\end{array}$ & $\begin{array}{c}\text { Limite } \\
\text { inferior }\end{array}$ & $\begin{array}{c}\text { Limite } \\
\text { superior }\end{array}$ & $\begin{array}{c}\text { Coeficiente } \\
\text { de variação }\end{array}$ \\
\hline 0,20 & 0,0074 & 0,0148 & 0,1852 & 0,2148 & 0,0369 \\
0,25 & 0,0080 & 0,0160 & 0,2340 & 0,2660 & 0,0319 \\
0,30 & 0,0085 & 0,0169 & 0,2831 & 0,3169 & 0,0282 \\
0,35 & 0,0088 & $0,017 \dot{6}$ & 0,3324 & 0,3676 & 0,0251 \\
0,40 & 0,0090 & 0,0181 & 0,3819 & 0,4181 & 0,0226 \\
0,45 & 0,0092 & 0,0184 & 0,4316 & 0,4684 & 0,0204 \\
0,50 & 0,0092 & 0,0184 & 0,4816 & 0,5184 & 0,0184 \\
0,55 & 0,0092 & 0,0184 & 0,5316 & 0,5684 & 0,0167 \\
0,60 & 0,0090 & 0,0181 & 0,5819 & 0,6181 & 0,0151 \\
0,65 & 0,0088 & 0,0176 & 0,6324 & 0,6676 & 0,0135 \\
0,70 & 0,0085 & 0,0169 & 0,6831 & 0,7169 & 0,0121 \\
0,75 & 0,0080 & 0,0160 & 0,7340 & 0,7660 & 0,0106 \\
0,80 & 0,0074 & 0,0148 & 0,7852 & 0,8148 & 0,0092 \\
\hline
\end{tabular}

Fonte: Pesquisa "Perfil dos Médicos no Brasil", Fiocruz/CFM. 
Tabela 8 - Erro absoluto e relativo na estimação da proporção "P". Brasil, Total - 1995

\begin{tabular}{cccccc}
\hline $\begin{array}{c}\text { Proporção } \\
\text { amostral }\end{array}$ & $\begin{array}{c}\text { Desvio } \\
\text { padräo }(\mathrm{P})\end{array}$ & $\begin{array}{c}(2 \mathrm{x}) \text { Desvio } \\
\text { padrão }(\mathrm{P})\end{array}$ & $\begin{array}{c}\text { Limite } \\
\text { inferior }\end{array}$ & $\begin{array}{c}\text { Limite } \\
\text { superior }\end{array}$ & $\begin{array}{c}\text { Coeficiente } \\
\text { de variaçáo }\end{array}$ \\
\hline 0,20 & 0,0045 & 0,0089 & 0,1911 & 0,2089 & 0,0223 \\
0,25 & 0,0048 & 0,0097 & 0,2403 & 0,2597 & 0,0193 \\
0,30 & 0,0051 & 0,0102 & 0,2898 & 0,3102 & 0,0171 \\
0,35 & 0,0053 & 0,0106 & 0,3394 & 0,3606 & 0,0152 \\
0,40 & 0,0055 & 0,0109 & 0,3891 & 0,4109 & 0,0137 \\
0,45 & 0,0056 & 0,0111 & 0,4389 & 0,4611 & 0,0123 \\
0,50 & 0,0056 & 0,0112 & 0,4888 & 0,5112 & 0,0112 \\
0,55 & 0,0056 & 0,0111 & 0,5389 & 0,5611 & 0,0101 \\
0,60 & 0,0055 & 0,0109 & 0,5891 & 0,6109 & 0,0091 \\
0,65 & 0,0053 & 0,0106 & 0,6394 & 0,6606 & 0,0082 \\
0,70 & 0,0051 & 0,0102 & 0,6898 & 0,7102 & 0,0073 \\
0,75 & 0,0048 & 0,0097 & 0,7403 & 0,7597 & 0,0064 \\
0,80 & 0,0045 & 0,0089 & 0,7911 & 0,8089 & 0,0056 \\
\hline
\end{tabular}

Fonte: Pesquisa "Perfil dos Médicos no Brasil", Fiocruz/CFM. 



\section{REFERÊNCIAS BIBLIOGRÁFICAS}

Аввот, A. The system of professions: an essay on the division of expert labor. London and Chicago: The University of Chicago Press, 1988.

Alves, J. G. (Coord.). Aspectos psicossociais do atendimento. Jornal Brasileiro de Medicina, 48(1/2):61-66, jan./fev. 1985.

ARaújo, A. R. A assistência médica hospitalar no Rio de janeiro no século XIX. Rio de Janeiro: Ministério da Educação e Cultura, Conselho Federal de Cultura, 1982.

AssociaÇão MÉDICa Brasileira (AMB). Tabela de honorários médicos. São Paulo: Comissão Nacional de Honorários Médicos, 1993.

ASSOCIAÇĀO MÉDICA MUNDIAL (AMM). Declaração de Genebra, [s.l.:s.n.], set. 1948.

BeCKer, H. S. \& Geer, B. Medical education. In: Freeman, H. E. Handbook of medical sociology. New Jersey: Englewood Cliffs, Prentice Hall, 1963.

BECKER, H. S. et al. Boys in white: student culture in a medical school. 3.ed. Chicago: University of Chicago Press, 1984.

BelisÁrıo, S. A. Médico-sanitarista: as muitas faces de uma ocupação, 1993. Dissertação de Mestrado, Rio de Janeiro: Escola Nacional de Saúde Pública, Fundação Oswaldo Cruz.

BERGER, J. \& OFFE, C. O futuro do mercado de trabalho: a necessidade de complementação de um princípio distributivo. In: Offe, C. Trabalho e sociedade: problemas estruturais e perspectivas para o futuro da "sociedade do trabalho". Rio de Janeiro: Tempo Brasileiro, 1989. v.1.

BerGer, J. \& OffE, C. Crescimento e racionalização do setor de serviços. In: OfFe, C. Trabalho e sociedade: problemas estruturais e perspectivas para o futuro da "sociedade do trabatho". Rio de Janeiro: Tempo Brasileiro, 1991. v.2.

BLAUNER, R. Alienation and freedom: the factory worker and his industry. Chicago: The University of Chicago Press, 1973. 222p.

BRASIL. Ministério da Educação e Cultura. O ensino médico no Brasil: a expansão da rede escolar. In: Documentos do ensino médico. Santa Maria: Imprensa Universitária da Universidade Federal de Santa Maria, 1972. p.01-59. 
BRASIL. Decreto-lei no 80.281. Diário Oficial da Uniāo, Brasília, 1977.

BRASIL. Constituição da República Federativa do Brasil, Brasília, 1988.

BRASIL. Decreto-lei no 98.377, 8 nov. 1989. Diário Oficial da União, Brasília, 1989.

BRASIL. Portaria Interministerial n²01, 12 jan. 1990. Diário Oficial da União, Brasília, 1990.

Campos, G. W. S. Os médicos e a política de saúde. São Paulo: Hucitec, 1988.

CANGUILHEM, G. O normal e o patológico. Rio de Janeiro: Forense-Universitária, 1966.

Chaves, M. \& Rosa, A. R. Educação médica nas Américas: o desafio dos anos 90 . Rio de Janeiro: Cortez, 1990. p.209.

Chorny, A.; Ganem, A. \& Vianna, L. W. Política de saúde no municipio do Rio de laneiro: subsídios para um debate. Rio de Janeiro: Lide, 1980.

COELHO, E. C. Físicos, sectários e charlatāes: a medicina em perspectiva histórico-comparado. In: MaChado, M. H. (Org.) Profissöes de saúde: uma abordagem sociológica. Rio de Janeiro: Ed. Fiocruz, 1995.

COHN, A. \& DONnancelo, M. C. Condiçōes do exercício profissional da medicina na área metropolitana de São Paulo, São Paulo: USP. Relatório de pesquisa, 1982. (Mimeo.)

Conselmo federal de Medicina (CFM - Brasil). Código de ética médica. Resolução nำ1.246/88. Brasília: Tablóide, 1990.

Conselho Federal de Medicina (CFM - Brasil). Resoluções Normativas. (separata). Brasília, out. 1965, jul. 1989.

Conselho Federal de Medicina (CFM - Brasil). Resoluçōes. Vols. XII, XIII e XIV. Brasília, 1989, 1993.

Conselmo Federal de Medicina (CFM - Brasil). Pareceres. Brasília, 1994. v.1.

CORDeiro, H. A. As empresas médicas: as transformaçōes capitalistas da prática médica. Rio de Janeiro: Graal, 1984.

COSTA, N. R. Lutas urbanas, controle sanitário: origens das políticas de saúde no Brasil. Petrópolis: Vozes, 1985.

COSTA, N. R. O Banco Mundial e a política social nos anos 90 - a agenda para a reforma do setor saúde no Brasil. In: COSTA, N. R. \& Ribeıro, J. M. (Orgs.) Política de saúde e inovação institucional: uma agenda para os anos 90. Rio de Janeiro: Secretaria de Desenvolvimento Educacional - Escola Nacional de Saúde Pública/Fundação Oswaldo Cruz, 1996. 196p.

CunHA, L A. A universidade temporã. Rio de Janeiro: Francisco Alves, 1986.

Dejours, C. A loucura do trabalho: estudo de psicopatologia do trabalho. Sāo Paulo: Oboré, 1987.

Dejours, C. Travail usure mentale: essai de psychopathologie du travail. Paris: Bayard, 1993.

Dejours, C. Psicodinâmica do trabalho: contribuições da escola dejouriana à análise da relação prazer, sofrimento e trabalho. São Paulo: Atlas, 1994.

Dejours, C. \& JAYet, C. Psicopatologia do trabalho e organização real do trabalho em uma indústria de processo: metodologia aplicada a um caso. In: DetIOL, M. I. (Coord.) Psicodinâmica do trabalho. São Paulo: Atlas, 1994.

Díaz-JOUANen, E. Las especialidades médicas: papel de las instituciones educativas y de las instituciones de salud. Gaceta Médica de Mexico, 126(1):25-26, 1990. 
Donnangelo, M. C. F. Medicina e sociedade: O médico e seu mercado de trabalho. São Paulo: Pioneira, 1975.

Donnancelo, M. C. F. (Coord.) Condiçōes do exercício da medicina na área metropolitana de São Paulo: relatório de pesquisa. São Paulo: Universidade de São Paulo/Conselho Regional de Medicina do Estado de São Paulo, 1980.

Donnangelo, M. C. F. \& Pereira, L. Saúde e sociedade. São Paulo: Duas Cidades, 1976.

DORAY, B. Le taylorisme, une folie rationnelle? Paris: Bordas, 1981. 183p.

DURKHEIM, É. Liçōes de sociologia: a moral, o direito e o Estado. São Paulo: Universidade de São Paulo, 1983.

DURKHEIM, É. Prefácio à segunda edição. In: Da divisão do trabalho social. São Paulo: Martins Fontes, 1995. p.5-41.

DusSAult, G. A gestão dos serviços públicos de saúde: características e exigências. Revista de Administração Pública, 26(2):8-19, 1992.

FALCÃo, S. A. A ética médica e suas infraçōes: um estudo sobre os processos éticos-profissionais do Estado do Rio de Janeiro, 1993. Dissertação de Mestrado, Rio de Janeiro: Escola Nacional de Saúde Pública/Fundação Oswaldo Cruz.

Faveret, P. F. \& Oliveira, P. J. A universalização excludente: reflexōes sobre as tendências do sistema de saúde. Revista de Planejamento e Políticas Públicas, (3):139-161, 1990.

Ferreira, J. R. A expansão da formação de médicos no Brasil. A Patologia Ceral, 49:121, 1964.

Freidson, E. La profesíon médica: un estudio de sociología del conocimiento aplicado. Trad. María Isabel Hirsch. Barcelona: Península, 1978.

FreiDSON, E. Medical work in America: essays on health care. London: Yale University Press, 1989.

GiRARDI, S. N. La fuerza de trabajo en el sector salud: elementos teóricos y evidencias empíricas. Educación Médica y Salud, 25(1):37-47, 1991.

GuIMARÄES, R. Fim de século: fim de ciclo? Ciência e Sociedade, abr. 1997.

HARDING, T. W. Validating a method of psychiatric case identification in Jamaica. Bulletin of the WHO, 54(2):225-231, 1976.

HAUG, M. R. Deprofessionalization: an alternate hypothesis for the future. In: HaLmOS, P. (Org.). Professionalisation and social change. Staffordshire: The University of Keele, 1973.

HAUC, M. R. A re-examination of the hypothesis of physician deprofessionalization. The Milbank Quarterly, 66:48-58, 1988.

instituto Brasileiro de Geografia e Estatística (IBGE). Pesquisa de assistência médico-sanitária. Rio de Janeiro: IBGE, 1980.

Instituto Brasileiro de Geocrafia e Estatística (IBGE). Pesquisa de assistência médico-sanitária. Rio de Janeiro: $I B C E, 1990$.

Instituto Brasileiro de Geocrafia e Estatística (IBCE). Pesquisa de assistência médico-sanitária. Rio de Janeiro: IBGE, 1991.

Instituto Brasileiro de Geografia e Estatística (IBGE). Pesquisa de assistência médico-sanitária. Rio de Janeiro: IBCE, 1992. 
JARDIM, S. R. Processo de trabalho e sofrimento psíquico: o caso dos pilotos do metrô carioca, 1994. Dissertação para Pós-Graduação, Rio de Janeiro: Instituto de Psiquiatria, Universidade Federal do Rio de Janeiro.

JERVIS, G. Manual crítico de psiquiatria. [s.l]: Anagrama, 1979. 408p.

KUCHENBECKER, R. O modelo operário italiano 30 anos depois. Saúde em Debate, (36):48-50, 1992.

LABRA, E. O movimento sanitarista nos anos 20: da conexão sanitária internacional à especialização em saúde pública no Brasil, 1985. Dissertação de Mestrado, Rio de Janeiro: Escola Brasileira de Administração Pública, Fundação Getúlio Vargas.

LARSON, M. S. The rise of professionalism: a sociological analysis. Los Angeles: University of California Press, 1977.

LARSON, M. S. Proletarianization and educated labor. Theory and Society, 9:131-175, 1980.

LAURELL, A. C. \& NorieGA, M. Processo de produção e saúde: trabalho e desgaste operário. São Paulo: Hucitec, 1989.

LEITE, I. B. \& MACHADO, M. H. A situação do mercado de trabalho dos médicos de Belo Horizonte. Belo Horizonte: Departamento de Medicina Preventiva e Social/Universidade Federal de Minas Gerais, 1981.

LEITE, I. B. \& MACHADO, M. H. La médica y el mercado de trabajo. Cuadernos Medico Sociales, (35):25-34, 1986.

Luz, M. T. A saúde e as instituiçōes médicas no Brasil. In: Gulmarāes, R. (Org.) Saúde e medicina no Brasil: contribuição para um debate. 5.ed. Rio de Janeiro: Graal, 1984. v.3.

MACHADO, M. H. A mão-de-obra feminina no setor saúde no Brasil. In: LABRA, M. E. (Org.) Mulher, saúde e sociedade no Brasil. Petrópolis: Vozes/Abrasco, 1989.

MACHADO, M. H. Women and the health sector's labor market in the Americas. Female hegemony?. In: COMEZ, E. G. (Ed.) Cender, women and health in the Americas. Washington, D.C.: Pan American Health Organization, 1993.

MACHADO, M. H. (Org.). Profissöes de saúde: uma abordagem sociológica. Rio de Janeiro: Ed. Fiocruz, 1995.

MACHADO, M. H. Os médicos e sua prática profissional: as metamorfoses de uma profissão, 1996. Tese de Doutorado: Rio de Janeiro, Instituto Universitário de Pesquisas do Rio de Janeiro.

MACHADO, M. H. et al. O mercado de trabalho em saúde no Brasil: estrutura e conjuntura. Rio de Janeiro: Escola Nacional Saúde Pública/Fundação Oswaldo Cruz, 1992. (Coleção Textos de Apoio).

MACHADO, M. H. et al. Especialidades médicas no Brasil. Dados, (17):2-31, 1995.

Machado, M. H. et al. Perfil dos médicos no Brasil. Relatório Final. 28v. Rio de Janeiro: Fiocruz/CFMMS-PNUD, 1996. (Coleção Médicos em Números).

MACIEL, R. Discurso de abertura do presidente da Abem. In: Anais da IX Reunião da Abem, 1971. Curitiba, Universidade Federal do Paraná, 1972.

MARI, J. J. A validity study of a psychiatric screening questionnaire (SRQ-20) in primary care in the city of São Paulo. Journal of Psychiatry, 148:23-26, 1986. 
MARTINS, M. I. C. As organizaçōes de saúde no contexto do SUS: uma realidade em construção, 1994. Dissertação de Mestrado, Rio de Janeiro: Escola Nacional de Saúde Pública, Fundação Oswaldo Cruz.

MARTY, P. L'ordre psychosomatique: les mouvements individuels de vie e de mort. Paris: Payot, 1980. v.2.

MCKINLAY, J. B. \& ARCHES, J. Hacia la proletarización de los médicos. Cuadernos Medico Sociales, (35):35-61,1986.

MECHANIC, D. Sources of countervailing power in medicine. Journal of Health Politics, Policy and Law, 16(3):485-498, 1991.

MÉDıcı, A. C. Estrutura e dinâmica da força de trabalho médica no Brasil na década de setenta. In: MÉdiCl, A. C. (Org.) Textos de apoio: Planejamento I, Recursos Humanos em Saúde. Rio de Janeiro: PEC/Ensp/Fiocruz, 1987.

MÉDICI, A. C. Mulher brasileira: muito prazer. In: LABRA, M. E. (Org.) Mulher, saúde e sociedade no Brasil. Petrópolis: Vozes/Abrasco, 1989. p.71-117.

MÉoıCI, A. C. \& SıIVA, P. L. B. A administração flexível: uma introduçāo às novas filosofias de gestāo. Revista de Administração Pública, 26(3):26-36, 1993.

Meto, C. G. A medicina previdenciária. In: Gulmarães, R. (Org.) Saúde e medicina no Brasil: contribuição para um debate. 5.ed. Rio de Janeiro: Graal, 1984. v.3.

MELO, O. C. Aspectos quantitativos e qualitativos da formação de médicos e plano de redistribuição geográfica dos mesmos. Revista Associação Médica Brasileira, 17(10):323-330, 1971

MiLls, W. A nova classe média: white collar. 3.ed. Trad. V. Borda. Rio de Janeiro: Zahar, 1979

MoYsés, N. M. N. Cuidados primários de saúde, uma estratégia?, 1986. Dissertação de Mestrado, Niterói: Faculdade de Educação, Universidade Federal Fluminense.

NoguerRa, R. P. Medicina interna e cirurgia: a formação social da prática médica, 1977. Dissertação de Mestrado, Rio de Janeiro: Instituto de Medicina Social, Universidade Estadual do Rio de Janeiro.

Nocuelra, R. P. Características econômicas da medicina liberal. Educación Médica y Salud, 25(2):118-125, 1991.

Offe, C. Trabalho e sociedade: problemas estruturais e perspectivas para o futuro da "sociedade do trabalho". Trad. G. F. Bayer. Rio de Janeiro: Tempo Brasileiro, 1989. v.1.

OFFE, C. Trabalho e sociedade: problemas estruturais e perspectivas para o futuro da "sociedade do trabalho". Trad. G. Bayer e M. Martincic. Rio de Janeiro: Tempo Brasileiro, 1991. v. 2 .

Oliveira, E. S. \& CAMPOS, M. Os empregos de saúde e a municipalização no Brasil. Rio de Janeiro: Ensp/Fiocruz, 1996. (Mimeo.)

Oliveira, E. S. \& Pinto, L. F. S. Os serviços de saúde no Brasil: a capacidade instalada no período de 80/92. In: EnCONTRO NaCional De Estudos Populacionals, 10, 1996, Caxambu. Anais... Belo Horizonte: Abep, 1996.

Oliveira, F. B. Pós-graduação: educação e mercado de trabalho. Campinas: Papirus, 1995.

OPPENHEIMER, M. White collar revisited: the making of new working class. Social Policy, 27-32, jul./ago. 1970. 
Oppenheimer, M. The proletarianization of the professional. In: Halmos, P. (Org.) Professionalisation and social change. Staffordshire: The University of Keele, 1973.

OPPenheImer, M. The unionization of the professional. Social Policy, 34-40, jan./fev. 1975.

PalÁcıos, M. P. Trabalho hospitalar e saúde mental: o caso de um hospital geral e público do município do Rio de Janeiro, 1993. Dissertação de Mestrado, Rio de Janeiro: Instituto de Medicina Social, Universidade Estadual do Rio Janeiro.

Pereira Neto, A. F. O sindicato e a profissāo médica no Brasil (1922/1931). Rio de Janeiro: Casa de Oswaldo Cruz/Fiocruz, 1992.

Pereira Neto, A. F. Palavras, intenções e gestos: os interesses profissionais da elite médica congresso nacional dos práticos, 1997, 428p. Tese de Doutorado, Rio de Janeiro: Instituto de Medicina Social, Universidade Estadual do Rio de Janeiro.

PERKIN, $\mathrm{H}$. The third revolution: professional elites in the modern world. London: Houtledge, 1996.

Pierantoni, C. Residência médica: meio século no Brasil. Rio de Janeiro: Instituto de Medicina Social/Uerj, 15p., 1994. (Série Estudos).

PItTA, A. Hospital: dor e morte como ofício. Săo Paulo: Hucitec, 1990. 198p.

Pos5as, C. Epidemiologia e sociedade. São Paulo: Hucitec, 1989.

ReCo, S. A prática na formação médica: o estágio extracurricular em questão, 1994. Dissertaçāo de Mestrado, Rio de Janeiro: Instituto de Medicina Social, Universidade Estadual do Rio de Janeiro.

RECO, S. \& PALÁCıOS, M. A organizaçāo do trabalho hospitalar e a formação dos estudantes de medicina nas emergências. Saúde em Debate, 50:95-100, 1996.

RıBeiro, J. M. Trabalho médico: ciência, arte e açāo na conformação da técnica, 1995, 600p. Tese de Doutorado, Rio de Janeiro: Escola Nacional de Saúde Pública, Fundação Oswaldo Cruz.

RIBEIRO, ]. M. \& COSTA, N. R. (Orgs.). Política de saúde e inovação institucional: uma agenda para os anos 90. Rio de Janeiro: Secretaria de Desenvolvimento Educacional/Ensp/Fiocruz, 1996. 193p.

Ribeiro, J. M. \& SChraiber, L. B. A autonomia e o trabalho em medicina. Cadernos de Saúde Pública, 10(2):190-199, 1994.

SAfFiotı, H. J. B. A mulher na sociedade de classes: mito e realidade. Petrópolis: Vozes, 1976, $384 \mathrm{p}$.

Santos Filho, L. C. História geral da medicina brasileira. São Paulo: Hucitec, 1991. 2v.

SANTOS Neto, P. M. O processo de profissionalização médica em Pernambuco: um estudo sobre a categoria médica pernambucana, sua organização, seus interesses, 1993. Dissertação de Mestrado, Rio de Janeiro: Escola Nacional de Saúde Pública, Fundação Oswaldo Cruz.

SANTOS, J. O. Educaçāo médica: filosofia, valores e ensino. Salvador: Arembepe, 1987.

SANTOS, M. R. Do boticário ao bioquímico: as transformações ocorridas com a profissão farmacêutica no Brasil, 1993. Dissertação de Mestrado, Rio de Janeiro: Escola Nacional de Saúde Pública, Fundação Oswaldo Cruz.

SANTOS, R. V. O processo histórico-social do trabalho e sua repercussão sobre a saúde. Saúde em Debate, 36:51-57, 1992. 
SAYEC, M. A. O mercado de trabalho dos médicos e do pessoal de enfermagem. In: MÉdICl, A. C. (Org.) Textos de Apoio: Planejamento I, Recursos Humanos em Saúde. Rio de Janeiro: PEC/Ensp/Fiocruz, 1987.

SChABRACQ, M. J.; WINNUBST, J. A. M. \& COOPER, C. L. Handbook of work and health psychology. Manchester: John Wiley \& Sons, 1996.

SCHRArBer, L. B. Educação médica e capitalismo. São Paulo: Hucited/Abrasco, 1989.

SCHRAiBer, L. B. O médico e seu trabalho: limites da liberdade. São Paulo: Hucitec, 1993.

SCHRAIBER, L. B. O trabalho médico: questōes acerca da autonomia profissional. Cadernos de Saúde Pública, 11(1):57-64, 1995.

Seliamann Silva, E. Saúde mental e trabalho. In: TunidS, S. \& COSTA, N. (Orgs.). Cidadania e loucura: polfticas de saúde mental no Brasil. Petrópolis: Vozes/Abrasco, 1987.

Selicmann SIL.VA, E. Desgaste mental no trabalho dominado. Rio de Janeiro: Ed. UFRJ, 1994.

SILVA FILHO, J. F. et al. Relatórios de pesquisa: organização do trabalho e saúde mental: estudo das relações entre a prevalência de doenças mentais e organização do trabalho bancário l, II, III, set./91 a ago./92. Rio de Janeiro: Instituto de Psiquiatria - UFRJ/FUJB/FBB, 1992. (Mimeo.)

SIMÕES, S. D. Classe médica profissional no Brasil: teoria e organizaçāo política e sindical. Revista Brasileira de Ciências Sociais, 16:160-199, 1992.

Sincer, P.; CAMPOS, O. \& OliveIRA, E. M. Prevenir e curar: o controle social através dos serviços de saúde. Rio de Janeiro: Forense-Universitária, 1988.

SOLARI, A. Desarrollo y política educacional en América Latina. Revista de la Cepal, $1^{\text {으 }}$ sem., 1997.

SORIO, R. E. A relação dos médicos com as organizaçōes públicas de saúde: um estudo exploratório, 1994. Dissertação de Mestrado, Rio de Janeiro: Escola Nacional de Saúde Pública, Fundação Oswaldo Cruz.

SouzA, A. M. O mercado de senviços e a dinâmica do mercado de trabalho, 1997, 55p. Dissertação para Graduação, Niterói: Faculdade de Economia e Administração, Universidade Federal Fluminense.

SouzA, O. Médicos em greve. Rio de Janeiro: Aroeira, 1982.

StARR, P. La transformación social de la medicina en los Estados Unidos de América. Trad. Agustín B. México: Fondo de Cultura Económica, 1991.

STEDEFORD, A. Encarando a morte: uma abordagem ao relacionamento com o paciente terminal. Porto Alegre: Artes Médicas, 1986.

Stotz, E. N. \& Giovanella, L. Globalizaçâo econômica, (des)regulação do mercado de trabaIho e (des)proteção social - apontamentos sobre a conjuntura na Alemanha. In: COSTA, $N$. R. \& RIBEIRO, J. M. (Orgs.) Polftica de saúde e inovação institucional: uma agenda para os anos 90. Rio de Janeiro: Secretaria de Desenvolvimento. Educacional/Ensp/Fiocruz, 1996.196p.

SuCupira, N. Prefácio. In: OliveırA, F. B. Pós-graduação: educação e mercado de trabalho. Campinas: Papirus, 1995. p.9-16.

Tedesco, J. C. Sociologia da educação. 4.ed. Campinas: Autores Associados, 1995. 125p. 
TEIXEIRA, M. et al. Trabalho e gestão em saúde - algumas considerações no contexto do SUS. In: Costa, N. R. \& Ribelro, J. M. (Orgs.) Política de saúde e inovaçăo institucional: uma agenda para os anos 90. Rio de Janeiro: Secretaria de Desenvolvimento Educacional/Ensp/Fiocruz, 1996. 196p.

Teixeira, S. M. F. \& Olivelra, J. A. A medicina e a fábrica. In: Guimarães, R. (Org.) Saúde e medicina no Brasil: contribuiçāo para um debate. 5.ed. Rio de Janeiro: Graal, 1984 v. 3.

ValtSMan, J. Biologia e História (ou, Por que a igualdade é possível). In: LABRA, M. E. (Org.) Mulher, saúde e sociedade no Brasil. Petrópolis: Vozes/Abrasco, 1989. p.25-38.

VERAS, C. M. T. Avaliaçāo da atenção médico-hospitalar no Rio de Janeiro. Caderno de Ciência e Tecnologia - Divulgação em Saúde para Debate, (3):64-70, 1991.

VIANNA, L. W. Liberalismo e sindicato no Brasil. 2.ed. Rio de Janeiro: Paz e Terra, 1978.

VIANNA, L. W. A classe operária e a abertura. São Paulo: Cerifa, 1983.

Weber, M. Ensaios de sociologia. Trad: Waltensir Dutra. 5.ed. Rio de Janeiro: Guanabara, 1982.

Weber, M. Economia y sociedad: esbozo de sociología comprensiva. Trad. José M. E., Juan R. P., Eugenio I., Eduardo G. M., José F. M. México: Fondo de Cultura Económica, 1984.

Formato: $16 \times 23 \mathrm{~cm}$

Tipologia: Zapfhumnst BT

Papel: Pólen Bold $70 \mathrm{~g} / \mathrm{m} 2$ (miolo)

Cartăo Supremo $250 \mathrm{~g} / \mathrm{m} 2$ (capa)

Impressão e acabamento 1å Reimpressão:

Millennium Print Comunicação Visual Ltda.

Rio de Janeiro, outubro de 1999

Não encontrando nossos títulos em livrarias, contactar a Editora Fiocruz:

Rua Leopoldo Bulhōes, 1.480, térreo - Manguinhos

Rio de Janeiro, RJ. CEP 21041-210

Tels.: (21) 598-2701 e 598-2702

Telefax: (21) 598-2509

E-mail: editora@fiocruz.br 